Portland State University

PDXScholar

1992

\title{
State Industrial Policy and the Autonomy of State Leaders: Evidence from the Oregon Experience
}

Matthew I. Slavin

Portland State University

Follow this and additional works at: https://pdxscholar.library.pdx.edu/open_access_etds

Part of the Urban, Community and Regional Planning Commons Let us know how access to this document benefits you.

\section{Recommended Citation}

Slavin, Matthew I., "State Industrial Policy and the Autonomy of State Leaders: Evidence from the Oregon Experience" (1992). Dissertations and Theses. Paper 1228.

https://doi.org/10.15760/etd.1227

This Dissertation is brought to you for free and open access. It has been accepted for inclusion in Dissertations and Theses by an authorized administrator of PDXScholar. Please contact us if we can make this document more accessible: pdxscholar@pdx.edu. 
STATE INDUSTRIAL POLICY AND THE AUTONOMY OF STATE LEADERS:

\section{EVIDENCE FROM THE OREGON EXPERIENCE}

by

MATTHEW I. SLAVIN

A dissertation submitted in partial fulfillment of the requirements for the degree of

DOCTOR OF PHILOSOPHY

in

URBAN STUDIES

Portland State University

1993 


\section{TO THE OFFICE OF GRADUATE STUDIES:}

The members of the Committee approve the dissertation of Matthew I.

Slavin presented June 26, 1991.

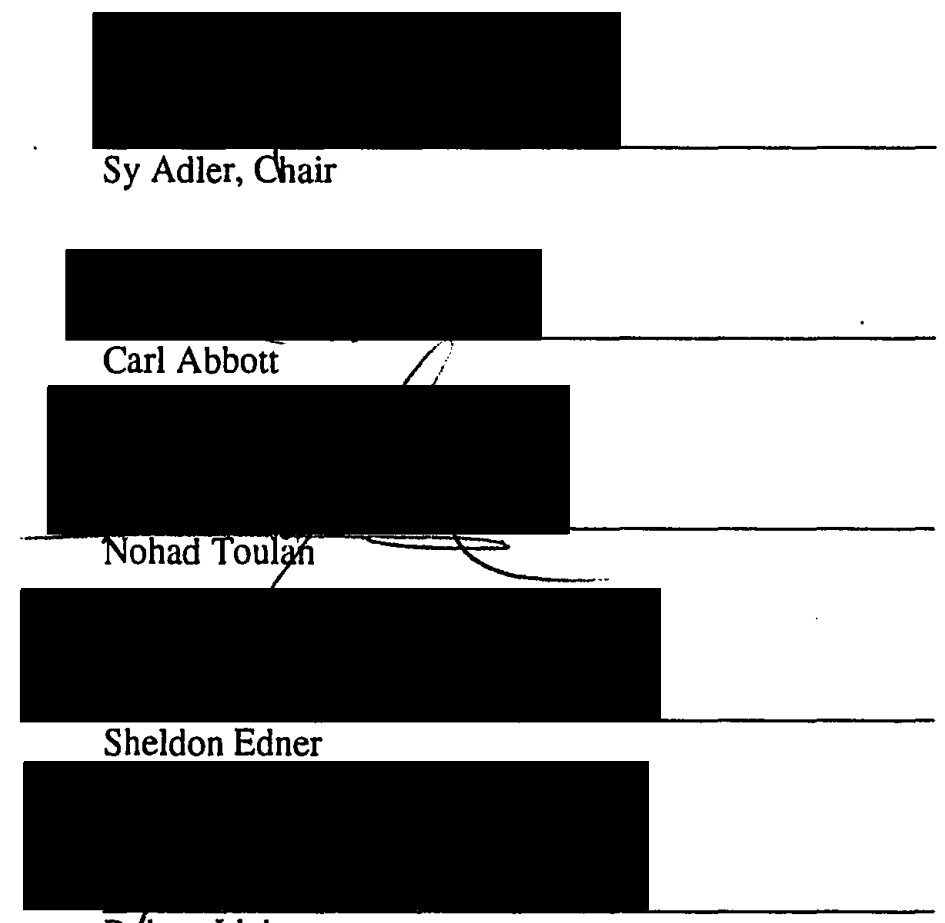

Røbert Liebman

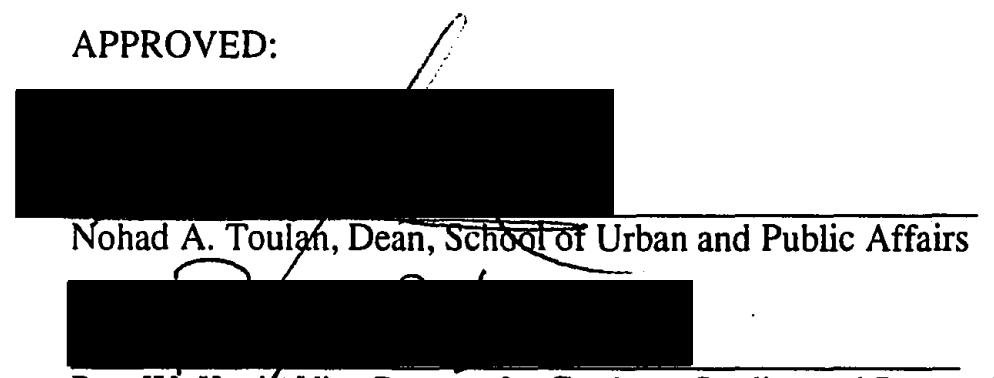

Roy W. Kock, Vice Provost for Graduate Studies and Research 
AN ABSTRACT OF THE DISSERTATION OF Matthew I. Slavin for the

Doctor of Philosophy in Urban Studies presented June 26, 1991.

Title: State Industrial Policy and the Autonomy of State Leaders: Evidence from the Oregon Experience.

APPROVED BY THE MEMBERS OF THE DISSERTATION COMMITTEE:

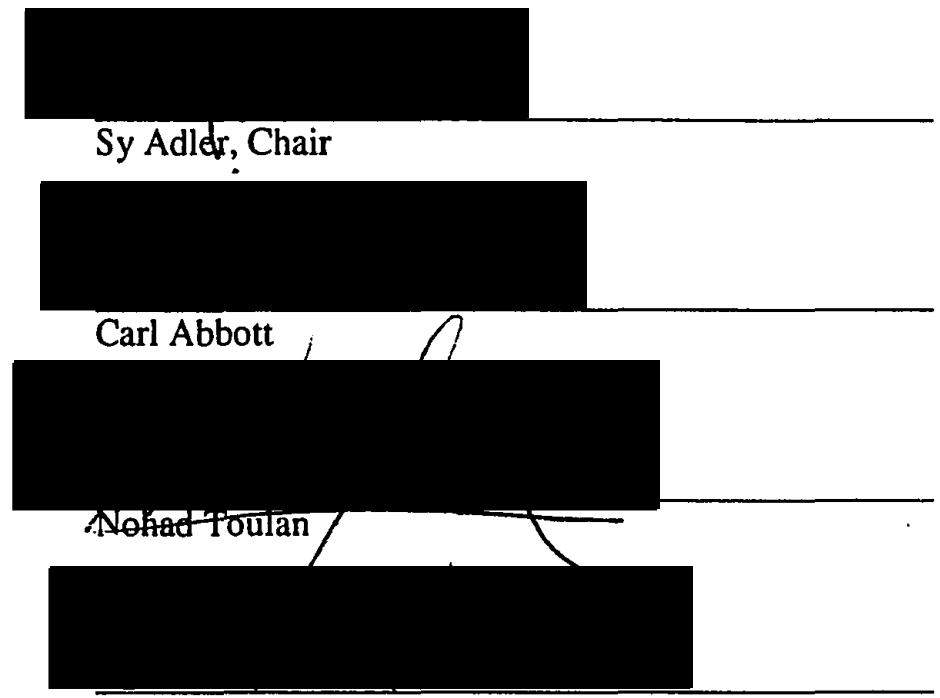

Sheldon Edner

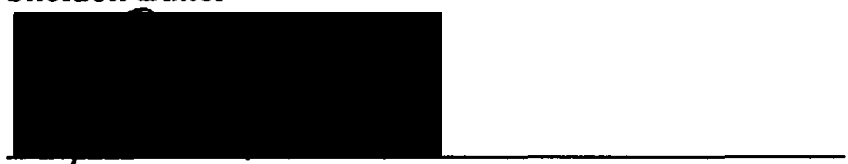

Robert Liebman

This research identifies variables that determined the amount of autonomy Oregon's gubernatorial leadership possessed in formulating and implementing the Regional Strategies program, centerpiece of industrial policy in Oregon during the latter half of the 1980s. The literature on state industrial policy points to instances in 
which the leaders of America's state governments are acting autonomously. Gubernatorial actors appear to be formulating industrial policy goals independent of powerful non-state groups and other state actors and developing the capacity to transform their policy preferences into authoritative actions. The literature is largely devoid, however, of any systematic accounting of the variables that determine the extent to which gubernatorial actors possess autonomy. Drawing upon interviews with key actors involved in formulating and implementing the Regional Strategies initiative and document research, this case study points to five principal sources of variation in gubernatorial success. These are as follows:

(1) Economic crisis. The inability of longstanding industrial recruitment practices to reconcile divisions caused by Oregon's deepest recession since the Great Depression eroded support for existing state economic development arrangements, enabling Oregon's newly elected Governor Neil Goldschmidt to reform state economic development policy along industrial policy lines and accumulate discretionary authority for state economic development spending denied his predecessors.

(2) The division of power between the executive and legislative branches of Oregon state government. Reacting to tensions founded in localism, regionalism, and concern with having its authority usurped, Oregon's legislature placed limitations upon Govemor Goldschmidt's industrial policy mandate. Legislatively-enforced measures precluded the competitive evaluation of local economic restructuring plans, frustrating a key Administration goal, and instead made equity and political expediency the driving force behind key industrial policy decisions. Legislators also 
denied the Administration authority it was seeking over semi-autonomous state agencies, impeding its plan to consolidate control over state economic development policymaking.

(3) State fiscal capacity. Industrial recruitment's failure led voters to establish a statewide lottery with proceeds dedicated to economic development. The lottery expanded Oregon's fiscal capacity for economic development, providing the Goldschmidt administration an instrument with which to fund industrial policy.

(4) The degree to which local interests were fiscally dependent upon state revenues. Administration success in securing key industrial policy goals was a direct consequence of its ability to use the discretionary authority it possessed over lottery spending to enforce local compliance with its policy preferences. The Administration proved more successful in circumstances in which local authorities were fiscally dependent upon gubernatorial controlled state lottery revenues for funding local economic development projects than in instances in which local interests were independent of the state for revenues.

(5) The character of private capital investment. Economic development is contingent upon the investment of private assets, over which Oregon's political leadership exercised little direct control. The failure of anticipated private investment to materialize frustrated Administration plans to use lottery money to leverage private investment in favored projects. Investment induced by Oregon's industrial policy initiative was likely to promote job growth in low wage sectors, frustrating the Administration's goal of using industrial policy to generate high wage jobs. 


\section{ACKNOWLEDGEMENTS}

A number of people made this dissertation a far more academically productive and personally enriching experience than it might otherwise have been. Above all is Sy Adler, my adviser at the School of Urban and Public Affairs and chair of my dissertation committee. Sy provided the impulse to many of the good ideas that shaped my dissertation and proved patient and thoughtful when I struggled with less worthy ideas. Sy never failed to express confidence in the value of my work even at times at which I was myself in doubt.

I want to thank the other members of my dissertation committee as well.

Like Sy, Carl Abbott provided initial stimulus to many of the ideas which found their way into this dissertation. As Dean of the School of Urban and Public Affairs, Nohad Toulan provided leadership to an institution within which my academic and intellectual skills could develop. Bob Liebman's advice for organizing my thoughts and defining key issues was especially important, nowhere so much as in the closing stages of this dissertation. Sheldon Edner played a similar role in my ability to clearly define and elaborate key issues, especially in the dissertation's early stage.

I am in debt to the Maury Clark Fellowship, funding from which enabled me to conduct the field research upon which this research is based.

To my friends Caroline Skinner, Chris Brown, and Karla Neupert, special thanks. Their willingness to put up with me throughout my work on this dissertation and their confidence in my ability to bring this dissertation to a successful conclusion went well beyond the call of duty. 
Last, I owe a special debt of gratitude to Dr. Woodrow Jones, who convinced me to return to graduate school at Portland State University. Without Woody's encouragement, I may never have started, much less completed, this dissertation. 
TABLE OF CONTENTS

PAGE

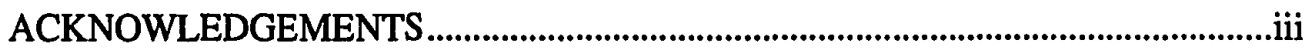

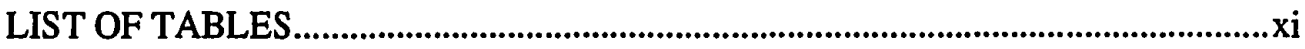

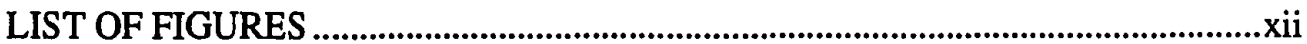

CHAPTER

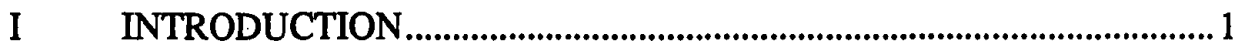

The Problem ................................................................................... 1

The Approach

The Contribution

Caveat

Organization of the Dissertation................................................6

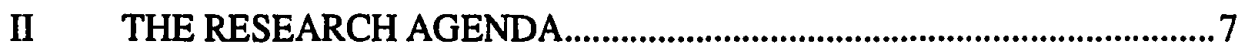

The Concept of State Autonomy ..................................................

Autonomy as a Prerequisite for Effective State Action

Limits on State Autonomy

State Capacity to Intervene

Autonomy of the Federalist American State

Industrial Recruitment: The Subordinate State .............................13

Industrial Policy: The Autonomous State...................................... 16

The Initial Impulse to Industrial Policy Will be Provided by Forces Arising Within State Government and not Private Groups

State Industrial Policy will Embody Goals Peculiar to State Leaders and Apart from those of Private Non-state Groups

State Leaders will Demonstrate an Ability to Override Opposition to their Industrial Policy Interventions

State Industrial Policy Focuses Public Resources Upon Emerging Sectors of the Economy 
The Programmatic Choices that Shape Industrial Policy will be Based Upon Objective Analysis

State Industrial Policy is Characterized by Concerted Action Amongst the Economic Development Agencies of State Government

The Shortfall of Theory

The Research Agenda..............................................................2

Research Boundaries

Methodology

Notes. .34

III THE IMPULSE TO INDUSTRIAL POLICY IN OREGON.....................35

Causes and Consequences of Oregon's Economic Crisis ...............35

The Failure of Industrial Recruitment .........................................40

Oregon as an Administratively Weak State

The Two Oregons

Labor's Disaffection

Business Sector Criticism

Early Industrial Policy Proposals

Erosion in Public Confidence

Summary

Notes.

IV BUILDING SUPPORT FOR INDUSTRIAL POLICY

Industrial Recruitment Repudiated.

Building an Industrial Policy Coalition

Seeking the Rural Vote

Securing Union Support

Building Bonds With Business

Submerging Differences

Mandate for Industrial Policy Reform

Summary

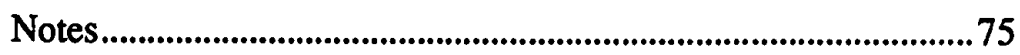


$\mathrm{V}$ THE POLITICS OF INDUSTRIAL POLICY ADOPTION.

Regional Strategies as Industrial Policy .......................................76

Political Opportunities in Regional Strategies ................................81

Legislative Constraints Upon Autonomy ......................................... 83

Gambling With Economic Development

Division of Powers

Regionalism

Localism

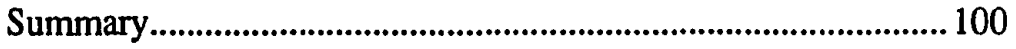

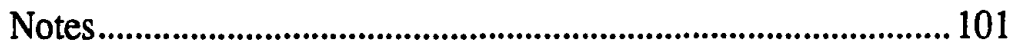

VI THE POLITICS OF IMPLEMENTATION: CENTRAL OREGON...... 102

The Politics of Prototype Choice................................................ 102

The Need for Regional Balancing

The Tourism Precedent

Strong Local Planning Capacity

Tourism as an Emerging Industry

The Character of Private Investment as a Limit Upon State Autonomy

The Politics of Tourism Strategy Selection

Bifurcated Support for Tourism

The Key Actors

The Growth Coalition

Lessons From the Project List.

Local Capacity for Economic Development Planning Revisited

Circumventing the Established Order

Subsidies

The Politics of Accommodation Confirmed

Summary

Notes. 
viii

VII IMPLEMENTING REGIONAL STRATEGIES IN SOUTHERN

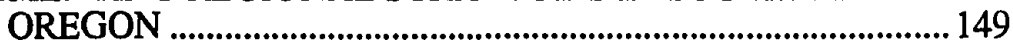

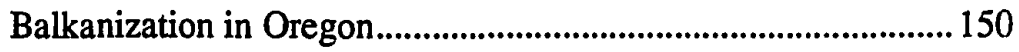

The Roots of Regional Divisiveness

Weak Planning Capacity

The Democratization of Strategy Selection

Inertia in Josephine County

Jackson County: Strategy by Consensus

Overriding Local Preferences.

Carrot and Stick Tactics

Strategy Membership Update

The Sunset Clause as Determinant of Gubernatorial Behavior

The No-Seconds Rule as a Limit Upon Gubernatorial

Success

The Project List

The Vicissitudes of Private Capital

Overcoming Institutional Barriers

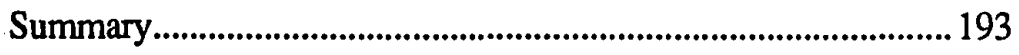

Notes.

VIII IMPLEMENTING REGIONAL STRATEGIES IN KLAMATH

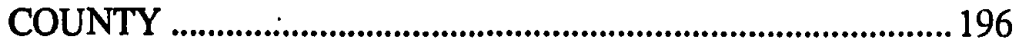

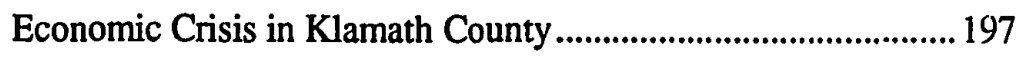

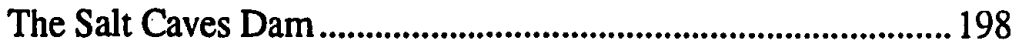

Operation Bootstrap

The Salt Caves Opponents

Operation Bootstrap Repudiated

The Light Industry Proposal

Institution Building at OIT

Kingsley Field

Klamath County's Growth Coalition

Capacity Advantage in Klamath County 
The Tourism Coalition .210

Tourism Proposal Denied Matching Funds

Subterfuge and Coercion

Tourism in Ascendancy

Revolt by Team Klamath

The Local Elites Prevail

Explaining Team Klamath's Success

The Status Quo Strategy ..............................................................224

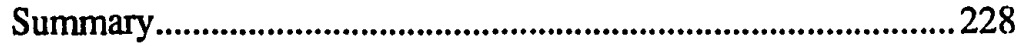

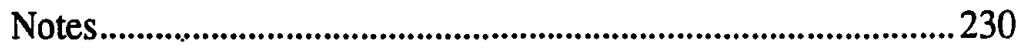

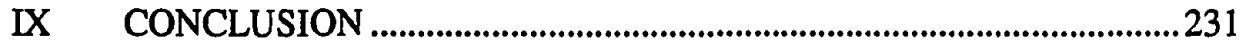

Recapitulation on State Autonomy............................................231

Evaluating the Postulates.............................................................232

The Initial Impulse to Industrial Policy Will be Provided by Forces Arising Within State Government and not Private Groups

State Industrial Policy will Embody Goals Peculiar to State Leaders and Apart from those of Private Non-state Groups

State Leaders will Demonstrate an Ability to Override Opposition to their Industrial Policy Interventions

The Programmatic Choices that Shape Industrial Policy will be Based Upon Objective AnalysisState Industrial

Policy Focuses Public Resources Upon Emerging Sectors of the Economy

State Industrial Policy is Characterized by Concerted Action Amongst the Economic Development Agencies of State Government

The Autonomy Variables

Economic Crisis

Division of Powers

Fiscal Capacity

Local Dependence

The Character of Private Capital Investment

Entrepreneurial Politics

Notes 


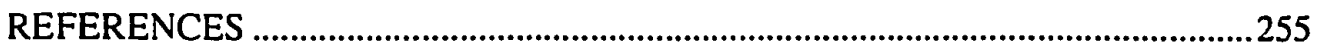

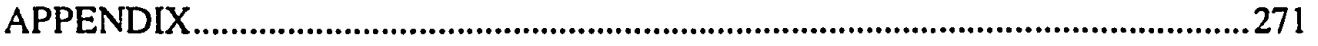




\section{LIST OF TABLES}

TABLE

PAGE

I Regional Strategies Summary Table ......................................................29

II Indicators of Economic Distress in Oregon...............................................36

III Selected Employment Figures for the United States, Oregon and Central Oregon ................................................................................................ 113

IV Distribution of Tourism Related Employment, Travel Generated Payroll Per-capita and Total Travel Expenditures in Central Oregon ..... 121

V Central Oregon Regional Strategy Project List........................................ 133

VI Share of Total Employment in Tourism, Total Travel Expenditures and Travel Generated Payroll Per-Capita in Southern Oregon ........... 159

YII Southern Oregon Regional Strategy Project List ........................................ 178

VIII Klamath County Regional Strategy Project List .......................................226 


\section{LIST OF FIGURES}

FIGURE

1. Map of Oregon .
PAGE 32 


\section{CHAPTER I}

\section{INTRODUCTION}

America's state governments have been involved in the promotion of local economic development since 1791 when the New Jersey legislature incorporated Alexander Hamilton's private company, the Society for Establishing Useful Manufacturers, as a vehicle for industrial development (Eisinger 1988). Modern state economic development policy dates to the Great Depression, when states began to use fiscal and other incentives to lure business investment to local communities, a practice known as industrial recruiting.

More recently, the post-1970 period has been marked by an notable shift in the character of state economic development activity away from industrial recruitment and towards industrial policy (Goldstein 1986). State industrial policy activity has drawn attention from a number of quarters. One sign of the interest state industrial policy activity has evoked are the major books offered on the subject by Eisinger (1988), Osborne (1988) and Fosler (1988).

\section{THE PROBLEM}

The literature on state industrial policy points to instances in which the leaders of America's state governments appear to act autonomously (Gray and Lowery 1989:4). Reference here is made to the ability of elected policy makers to formulate and pursue goals peculiar to themselves and apart from those of non-state groups. 
While the leaders of America's state governments appear to act autonomously in some of their industrial policy interventions, in other instances, state industrial policy activity appears to be shaped less by state leaders than by the interests of private, non-state groups. This suggests that the autonomy state leaders possess in their industrial policy interventions is situational. Unfortunately, case studies of state industrial policy activity are largely devoid of the type of systematic framework useful for identifying both the circumstances in which autonomous action is evinced and the limitations upon the amount of autonomy state leaders possess. In consequence, the literature on state industrial policy raises more questions about the amount of autonomy state leaders enjoy in their industrial policy interventions than it answers.

The question of how much autonomy political leaders possess in formulating and implementing public policy is important. It is widely assumed among modern political theorists that political leaders have interests apart from those of non-state groups and that political leaders embody these goals in their public policy interventions (Gurr and King 1987). Analysts have used the concept of state autonomy to analyze economic and social policy in the United States and Western Europe (Heclo 1974; Weir and Skocpol 1985; Gurr and King 1987) and Taiwan (Amsden 1985). These treatments have made valuable contributions to our understanding of public policy. It is likely that America's state governments have interests apart from those of private groups and actors and seek to embody these goals in their public policy interventions. The literature points to three such interests. These are 1) the state's role in providing public goods; 2) maximizing their tenure in office; and 3) maximizing the budgetary and administrative capacity of the bureaucratic apparatus over which the state leaders themselves preside (Rueschemeyer and Evans 1985:44-45; Gurr and King 1987:14-17). 
This research examines the variables that define the amount of autonomy that state leaders possess in formulating and securing these types of goals through industrial policy. It analyzes the case of the Regional Strategies program, centerpiece of state industrial policy activity in Oregon during the latter half of the 1980s under the administration of Governor Neil Goldschmidt.

The Approach

The current research creates a record of the key events that characterized formulation and implementation of the Regional Strategies program. These events are interpreted within an analytical framework that serves to distinguish how programmatic features indicative of state autonomy were manifested in the Regional Strategies policy process. The framework consists of six features which, drawn from the literature, are as follows:

- The initial impulse to industrial policy will be provided by forces arising within state government and not private groups.

- $\quad$ State industrial policy will embody goals peculiar to state leaders and apart from those of private non-state groups;

- State leaders will demonstrate an ability to override opposition to their industrial policy interventions;

- The programmatic choices that shape industrial policy will be based upon objective analysis;

- State industrial policy focuses public resources upon emerging sectors of the economy; and

State industrial policy is characterized by concerted action amongst the economic development agencies of state government. 
The Contribution

Drawing upon this framework, I conclude that the Goldschmidt

Administration ability to act autonomously varied with place, time and the

constellation of actors involved in the Regional Strategies process. My analysis points

to the following sources of variation in the amount of autonomy possessed by

Oregon's state leaders in formulating and implementing industrial policy:

Economic crisis: The inability of longstanding industrial recruitment practices to reconcile divisions caused by Oregon's deepest recession since the Great Depression eroded support for existing state economic development arrangements, enabling Oregon's newly elected Governor Neil Goldschmidt to reform state economic development policy along industrial policy lines and accumulate discretionary authority for state economic development spending denied his predecessors.

The division of power between the executive and legislative branches of Oregon state government: Reacting to tensions founded in localism, regionalism, and concern with having its authority usurped, Oregon's legislature placed limitations upon Governor Goldschmidt's industrial policy mandate. Legislatively-enforced measures precluded the competitive evaluation of local economic restructuring plans, frustrating a key Administration goal, and instead making equity and political expediency the driving force behind key industrial policy decisions. Legislators also denied the Administration authority it was seeking over semi-autonomous state agencies, undermining its plan to consolidate control over state economic development policymaking.

State fiscal capacity. Industrial recruitment's failure led voters to establish a statewide lottery with proceeds dedicated to economic development. The lottery expanded Oregon's fiscal capacity for economic development, providing the Goldschmidt administration an instrument with which to fund industrial policy.

The degree to which local interests were fiscally dependent upon state revenues. Administration success in securing key industrial policy goals was a direct consequence of its ability to use the discretionary authority it possessed over lottery spending to enforce local compliance with its policy preferences. The Administration proved more successful in circumstances in which local authorities were fiscally dependent upon gubernatorial controlled state lottery revenues for funding local economic development projects than in instances in which local interests were independent of the state for revenues. 
The character of private capital investment. Economic development is contingent upon the investment of private assets, over which Oregon's political leadership exercised little direct control. The failure of anticipated private investment to materialize frustrated Administration plans to use lottery money to leverage private investment in favored projects. Investment induced by Oregon's industrial policy was likely to promote job growth in low wage sectors, frustrating the Administration's goal of using its industrial policy to generate high wage jobs.

Last, I argue that efforts to overcome limitations upon its ability to act in implementing industrial policy led the Goldschmidt Administration to practice an entrepreneurial form of politics in which is circumvented established channels of public authority in an attempt to reorder the political environment within which it operated.

\section{Caveat}

One thing I do not attempt to do here is to measure the extent to which the Regional Strategies program actually resulted in economic development. My concern is with the issue of state autonomy and not with program impacts. As a practical matter, however, attempts to measure the amount of development resulting from the Regional Strategies program would face formidable obstacles. For one thing, this analysis is concerned mainly with the time period leading up to the inception of the Regional Strategies program and the first two years of the program's implementation (1987-88). It is unlikely that measurable changes in job growth and development would show up in such a brief period. More importantly, the rate and character of local economic development is a function of an innumerable host of factors of which state government's role is but one. Furthermore, it is commonly held that whatever role state government plays in promoting local economic development, its role is subordinate to federal fiscal and monetary policy and the overall level of activity in the greater national and world economies (Blakely 1989). It would thus be very 
difficult if not impossible to specifically measure the degree to which the Regional Strategies program per-se resulted in economic development.

I do make some remarks on the likely character of development if the Regional Strategies program was to have its intended effect. However, it is to highlight issues pertaining to state autonomy that these remarks are directed. The concern here is with state autonomy and not with measuring with measuring program impacts.

\section{ORGANIZATION OF THE DISSERTATION}

Chapter II reviews the literature to identify the principal features indicative of state autonomy and sets forth the methodology employed in examining my hypothesis, including my data and information collection techniques. Chapters III, IV, and V present a detailed record of the actors and interests, events and circumstances that shaped formulation of the Regional Strategies initiative. Chapters VI, VII, and VIII record of the forces that shaped implementation of the Regional Strategies initiative in each of three different regions of Oregon: Central Oregon, Southern Oregon, and Klamath County. In each case, attention is focused upon using the record presented to address the hypothetical concerns posited above. In Chapter IX, the concluding chapter, I draw upon preceding discussion to identify the five above cited sources of variation in the amount of state autonomy evinced in formulation and implementation of the Regional Strategies program. 


\section{CHAPTER II}

\section{THE RESEARCH AGENDA}

The concept of state autonomy is central to the state-centered paradigm for public policy analysis. State-centrism can be contrasted to the two paradigms which have traditionally dominated public policy analysis in the liberal democracies of North America and Western Europe. These are pluralism and Marxism. While scholars have developed revisionist perspectives on these two paradigms, the fundamental tenets of each remain little changed. In the pluralist view, government is the instrument through which competing and collaborating groups express their policy preferences. Public policy simply allocates the benefits and costs of public activity that arise from this competitive and collaborative process. Marxists view the state as an arena for class struggle and public policy as an instrument through which dominant classes aim to guarantee favorable production relations and promote accumulation. Both Pluralism and Marxism are society centered, viewing public policy as an instrument embodying the demands of private interest groups. 1

\section{THE CONCEPT OF STATE AUTONOMY}

Events in the post-Second World War period have led political theorists to recognize that the structure of the state and the timing and character of state policy action shape how private groups define their own interests, influence the organizational tactics and strategies employed by interest groups, encouraging some types of group formation and collective action but not others, and raised certain kinds of political issues but not others (Rueschemeyer and Evans 1985:253). Neither of the 
society centered paradigms serves well to explain policymaking which does not simply translate social demands into policy but shapes the nature of social action as well (Skocpol 1985: 4-6). This recognition served as an impulse to the emergence of the state-centered paradigm, which eschews the view of public policy as simply a response to the demands of social groups.

\section{Autonomy as a Prerequisite for Effective State Action}

The state-centered paradigm is founded upon the theory that state leaders have interests separate and apart from those of non-state groups and that state leaders embody these interests in the programmatic arrangements that define their public policy interventions. The literature points to three such interests. One is the state's role in providing public goods (Rueschemeyer and Evans 1985:44-45). The legitimacy of the state depends upon its ability to provide public goods. Private actors, with a focus upon short-term profitability, will not find it in their interests to provide public goods. A second interest setting state leaders apart from private groups is a desire to maximize their tenure in office. Private actors do not share in this interest since, by definition, they do not hold public office. Third, state leaders have an interest in maximizing the budgetary and administrative capacity of the bureaucratic apparatus over which they preside since doing so is likely to enhance their ability to attain their other programmatic objectives (Gurr and King 1987:14-17)

The extent to which state leaders are able to translate their interests in public goods provision, political perpetuation and bureaucratic capacity building into a programmatic set of goals is contingent upon the degree of autonomy they are able to acquire from dominant interest groups. The autonomous state leader retains a degree of power independent from non-state groups and may employ this power to formulate and pursue goals that are not simply reflective of the demands of interest groups 
(Skocpol 1984:9; Held 1987:115). Autonomous state leaders "may choose to align the state and its policies with one or another societal interest, but that is a matter of choice more than a response to structural necessity (Gurr and King 1987:9).

Leaders of capitalist states must acquire a certain degree of autonomy if they are to effectively formulate and implement public policy (Rueschemeyer and Evans 1985:49-68). Effective policy action requires that the state possess sufficient resources. In capitalist economies, the state must extract these resources from the private economy, primarily in the form of taxes. The manner in which the state extracts resources distributes different burdens upon different groups and individuals.

By the same measure, in its public policy interventions, the state differentially distributes benefits. Conflict will surround the state's role in determining how the costs and benefits of state action will be distributed, as private groups compete, seeking to benefit from and avoid the cost of state action. State leaders must acquire some measure of autonomy in order to resolve these conflicts over the distribution of costs and benefits if they are to effectively execute public policy interventions.

\section{Limits on State Autonomy}

The degree to which public policy interventions reflect autonomous action by state leaders is reflected in the extent to which they translate their "preferences into authoritative actions [and] the degree to which public policy conforms...to [the] resource-weighted preferences of [political leaders]" (Nordlinger 1981:20). State leaders never act wholly autonomously; instead state leaders possess relative autonomy. This is because state autonomy is always subject to constraints. For this reason, it is appropriate to speak of the relative autonomy of state leaders.

The literature points to four key constraints upon the autonomy of state leaders. First and foremost, the degree of autonomy that leaders of capitalist states 
may exercise is constrained by the state's dependence upon the private economy for the revenues needed to finance state operations and to provide the public goods upon which political support depends. Capitalists unhappy with state action may withhold the investment of their assets, denying the state the revenues it needs to conduct its policy interventions (Block 1977).

State autonomy is also constrained by technical, institutional, and political limitations (Gurr and King 1987:21-22). Effective policy formulation and implementation requires the efficient collection and processing of information. Technical constraints refer to limitations upon the ability of state leaders to acquire and process this information. Institutional constraints refer to limitations on the ability of state leaders to get individuals and the complex bureaucratic organizations that comprise the state apparatus to act as state leaders want them to act. Political restraints refer to the limitations upon the autonomy of state leaders founded in the division of powers between different branches of government, including the executive, legislature, and courts.

The literature points to certain situations which are likely to increase the prospects for state leaders to override these constraints and act autonomously. Most importantly, state autonomy is likely to be enhanced under crisis conditions, when existing policy arrangements break down. Resultant divisions within dominant classes or between interest groups may lead to an increase in the autonomy of state leaders. Pressure for change from subordinate classes or interest groups may also lead to an increase in state autonomy (Rueschemeyer and Evans 1985:63). The collapse of existing policy arrangements that accompanies crisis may free:

government officials (or aspiring politicians) [to undertake] new initiatives, conceivably well ahead of social demands, if existing state capacities can be readily adapted or reworked to do things that will bring 
advantages to them in their struggles with competitive forces (Weir and Skocpol 1985:118).

\section{State Capacity to Intervene}

The concept of state autonomy is founded not only upon the assumption that state leaders have interests separate from those of dominant social groups, but that state leaders also possess the ability to act on their interests and transform their preferences into authoritative actions. The degree to which state leaders can act autonomously in pursuit of their interests is largely contingent upon the fiscal and administrative capacity of the bureaucratic apparatus over which they preside.

Fiscal capacity is defined in terms of the fiscal resources state leaders may command in conducting public policy. State leaders are more likely to be able to pursue their goals if they exercise discretionary control over public monies as opposed to having public monies dedicated for specific uses (Rueschemeyer and Evans 1985). State leaders are also more likely to be able to pursue their goals if the groups whose behavior they are hoping to influence through their policy interventions are fiscally dependent upon, as opposed to independent of, the state for the revenues necessary to their operation (Gurr and King 1987:124).

Administrative capacity is defined primarily in terms of access to a well developed policy delivery system. As regards the administrative capacity of the state apparatus in capitalist, federalist democracies, there is something of a paradox. Federalist systems of government are usually characterized by fragmentation and a lack of cohesion within and across different levels of government. Federalist bureaucracies are fungible; private groups may seek to exploit bureaucratic fungibility for the purpose of directing public interventions towards aims other than those state leaders embrace. Public bureaucratic organizations may develop internal goals 
separate from those of state leaders. It is generally held that state leaders must command integral control of the complex organizations involved in policy delivery if they are to overcome these centrifugal tendencies and translate their policy preferences into authoritative actions, control best achieved through centralization. On the other hand, effective policy formulation and implementation requires the efficient collection and processing of information, operations which are best accomplished by decentralized administrative structures. Also, in a market economy with a federated system of government; decentralization is required for the state apparatus to be able to establish the linkages needed to ensure the responsiveness of private market forces and other levels of public authority (Skocpol 1985:16-17; Rueschemeyer and Evans 1985:49; 55-57).

\section{Autonomy of the Federalist American State}

According to Skocpol (1985:12), "there is less structural basis for state autonomy in the United States than in any other modern liberal capitalist nation." The reasons are found in America's decentralized economy and system of federal governance.

More so in America than in most other western democracies, there is little public control over strategic parts of the economy. This limits the ability of state leaders to mobilize economic resources for public purposes while making them highly susceptible to the veto capitalists can exercise over state behavior. Similarly, more so in America than in other western democracies, public authority is divided among different branches and levels of government which are highly fungible and susceptible to penetration by interest groups (Skocpol 1985:23-24). The fragmentation that characterizes American government impedes concerted action by public bureaucracies both within the same and between different levels of government. The proliferation of 
special committees that characterizes America's multi-cameral legislatures allows interest groups multiple points of access to the governing process. Legislatures may impede executive initiatives because they view them as a "power grab that could strip [their] authority and disrupt carefully cultivated relationships among congressional committees, interest groups, and...administrative agencies" (Weir and Skocpol 1985:141). Also, more so in America than in other western democracies, public authority is rooted in local bases of power. American federalism affords local governments a central role in the public policy process. To the degree that local economies generate revenues sufficient to reduce local government dependence upon revenues from higher levels government, local government leaders may pursue goals apart from those of higher levels of public authority, posing additional obstacles in the way of the ability of superior state leaders to attain their goals (Gurr and King 1987:124). For all of these reasons, public policy in America is less likely to embody the cohesive goals of autonomous state leaders than a conglomeration of disparate goals cast in piecemeal terms (Weir and Skocpol 1985).

\section{INDUSTRIAL RECRUITMENT: THE SUBORDINATE STATE}

The origins of modern state economic development policy trace back to the Great Depression when America's state governments began to use fiscal and other incentives to lure business investment to local communities, a practice known as industrial recruiting. The operational routines through which industrial recruitment interventions unfold varies with place. By all indications, however, there is little in industrial recruitment activity that is indicative of state autonomy.

Industrial recruitment reflects the competitive environment within which economic development takes place in America. In America, the owners of mobile 
capital can choose to invest in any state or locality they desire. Business interests whose profitability is tied to local place economies will compete to attract mobile capital. Their efforts transform government into a focus of growth-related activity. Locally-based business interests will seek to harness public resources in pursuit of their goals by recruiting government officials into growth coalitions--coalitions "of interest, recruited and organized along territorial lines...to attract scarce capital" (Logan and Molotch 1987:34-35). The dependence of state organizations upon revenues extracted from the private economy makes state leaders susceptible to growth coalition recruitment and precludes state leaders from shaping their economic development interventions in terms adverse to business.

Because the owners of mobile capital can choose to invest in any state or. local community they desire, they may play states and local communities against each other in seeking to secure the most favorable investment conditions. State and local governments must respond to the demands of private capitalists if they are maintain a level of investment necessary for sustaining social and economic viability. This has led state governments to use their regulatory powers to enact measures aimed at creating permissive business climates. They have acted to see that their rates of business taxation and labor, environmental, land use, and other regulatory regimes are more favorable than those found elsewhere (Pierce, Hagstrom, and Steinbach 1979; Swanstrom 1985:141-145; Logan and Molotch 1987; Cox and Mair 1988).

The same circumstances that drive state governments to provide permissive business climates have led the leaders of America's state governments to engage in industrial recruitment. Industrial recruitment activities reflect the inability of state government officials to make critical choices between particular industries; the incentives offered under the aegis of industrial recruitment are typically offered 
indiscriminate of the type of business activity a beneficiary is involved in. Industrial recruitment involves little analysis of the overall costs and benefits of recruiting particular enterprises to different communities or regions and the degree to which recruitment of a business enterprise will contribute to the long-term welfare of local residents (Litvak and Daniels 1981; Eisinger 1987).

Industrial revenue bonds (IRB) are the most prevalent industrial recruitment incentive. With the passage of enabling legislation in Idaho in 1982, all fifty U.S. states governments offered IRB funding to businesses willing to invest in local communities.(Eisinger 1988:157-158). Industrial revenue bonds are revenue bonds issued by the state on behalf of specific enterprises (Litvak and Daniels 1979). This makes IRB's a dedicated source of funding over which state leaders can exercise little discretionary authority.

In many cases, the costs associated with the incentives offered under the aegis of industrial recruitment are either hidden off budget or externalized. Industrial revenue bonds help illustrate this point. Because they are revenue bonds, indebtedness lies not with the issuing authority but with the beneficiary firm. Hence, IRB's impose little direct cost upon state and local government finances (Litvak and Daniels 1979:99-101; Swanstrom 1985). The incentives at the core of industrial recruitment activities are typically administered by a "line agency of state government, typically a department of economic development or commerce" (Fosler 1998:4). Industrial recruitment activities often involve other state and local government agencies as well, including state highway and employment departments and local land planning agencies and community colleges. To the degree that several government agencies are involved in industrial recruitment, their activities are usually conducted by means of 
ad-hoc contacts between representatives of the recruited firm and individual agencies (Litvak and Daniels 1979:99-101; Swanstrom 1985).

The incentives offered under industrial recruitment activities impose few direct costs upon state and local government finances. Being characterized by institutional fragmentation and little coordination between state and local government agencies, industrial recruitment also places minimal demands upon the administrative apparatus of government. The modest fiscal and administrative demands industrial recruitment places on public authorities helps explain the popularity industrial recruitment has enjoyed as the centerpiece of state economic development policy, according to Litvak and Daniels (1981:99-101).

\section{INDUSTRIAL POLICY: THE AUTONOMOUS STATE}

The framework I employ in this analysis consists of six features which the literature points to as being indicative of state autonomy. Although these features are not mutually exclusive, they are treated individually here. Doing so helps identify the different contexts within which the amount of autonomy state leaders possess in their industrial policy interventions can be viewed. Phrased as postulates, the six features are as follows:

The Initial Impulse to Industrial Policy will be Provided by Forces Arising Within State Government and not Private Groups

America's state governments came to embrace industrial policy amidst the economic distress that prevailed throughout much of America during the 1970s and 1980s. The decline of traditional industries led to widespread joblessness. State revenues were reduced, impairing state government's ability to provide public health, welfare, safety and environmental services. State leaders saw this as a threat to their 
prospects for remaining in public office (Eisinger 1988). At the same time, state leaders came to see traditional industrial recruitment practices as an unlikely remedy to the distress afflicting their states.

In part, confidence in industrial recruitment was undermined by academic studies showing that state-provided incentives to have a marginal influence upon the locational decisions of most firms. These studies showed such longstanding business concerns as securing an adequate supply of labor and energy, access to markets and raw materials and agglomeration economies to be the dominant influences upon business location (Steinnes 1977; Wasylenko 1980; Pascerella and Raymond 1982; Marlin 1982; Schmenner 1983; Swanstrom 1985; Howland 1986; Ambrosius 1986). Confidence in industrial recruitment was also undermined by several highly publicized and costly industrial recruitment failures. In the most prominent case, Pennsylvania provided over $\$ 65$ million in low cost loans, highway and rail improvements, worker training subsidies and local tax abatements for construction of a Volkswagen manufacturing plant. However, Volkswagen generated only half the number of jobs it promised and the plant was closed in 1987, after only ten years of operation (Osborne 1988:46). In another prominent industrial recruitment failure, the City of Yonkers spent over $\$ 3.5$ million to subsidize construction of a plant for Otis Elevator. Otis was subsequently taken over by United Technologies, which closed the plant after only five years of service (Eisinger 1988:316-317).

Governors disaffected with industrial recruitment set out to devise new policy arrangements which could promote economic development, bolster tax revenues and thus, bolster their political fortunes. In some cases, govemors directed staff in their own offices to devise industrial policy arrangements. Osborne (1988) and Ferguson and Ladd (1988) describe Governor Michael Dukakis as having employed this 
approach in Massachusetts. Elsewhere, governors created independent commissions and directed them to promulgate industrial policy arrangements, as in Rhode Island Eisinger (1988) credits the political leadership of these states with having taken the lead in promulgating industrial policy arrangements apart from conventional budget deliberations and in advance of the demands of private groups.

Theory posits that autonomous state leaders can initiative policy activity independent of private non-state groups. These depictions of the role public authorities played in Massachusetts and Rhode Island are indicative of autonomous state behavior.

State Industrial Policy will Embody Goals Peculiar to State Leaders and Apart from those of Private Non-state Groups

Governors including Michael Dukakis of Massachusetts and Jim Blanchard of Michigan embraced industrial policy arrangements because they recognized that industrial recruitment was unlikely to resolve the economic crises that threatened their ability to provide public goods and hence threatened their future political fortunes (Osborne 1988). This points to two goals embodied in state industrial policy interventions. One is to bolster state government's ability to provide public goods. The other is to extend the tenure in public office state leaders enjoy. Both of these goals are indicative of autonomous behavior.

State Leaders will Demonstrate an Ability to Override Opposition to their Industrial Policy Interventions

Gray and Lowery (1989:4) argue that governors have succeeded in shaping industrial policy arrangements "in the face of opposition of major private interests." They cite as an example the case of Rhode Island where the state's political leadership put together the Greenhouse compact, a 976 page, $\$ 750$ million industrial policy plan 
to restructure Rhode Island's economy over the opposition of not only powerful business interests but over the opposition of powerful labor groups as well. Ferguson and Ladd (1988) depict Governor Dukakis as having overcome opposition by powerful Boston area business groups in forging industrial policy in Massachusetts. Osborne (1988:48- 80) credits Pennsylvania's Governor Thornburgh with having created the Ben Franklin Partnership, modeled along industrial policy lines and "perhaps the best economic development system in the country," despite opposition from workers in traditional industries and their elected officials. Osborne (1988:145174) credits Michigan's Governor Blanchard with having forged industrial policy initiatives in Michigan over the opposition of the state's labor unions, perhaps the most politically powerful in the nation (Peirce and Hagstrom 1983:253-258).

The literature explains the success state leaders appear to have enjoyed in overcoming opposition to their industrial policy activities in terms of two factors. First is the diminished credibility of the two groups commonly viewed as being key actors in the economic development policy domain: business and labor. Eisinger (1988:78-80) holds that the distress experienced throughout much of America during the 1970 s and 1980 s demonstrated the inability of traditional business practices to provide for economic viability. This undermined the legitimacy of business claims to leadership in the economic development domain. By the same measure, many attributed the declining competitiveness of the American and steel industries to exorbitant labor contracts. This undermined organized labor's influence upon state economic development activity. With their credibility diminished, these groups have found themselves less able to block policy initiatives they opposed and hence, state leaders have found themselves more successful in overriding their opposition.

Next, Bowman and Kearney (1986) cite reductions in the amount of federal aid flowing directly to local governments as a factor explaining the success state 
leaders have enjoyed in overriding opposition to their industrial policy initiatives.

With federal aid to local governments either reduced or being channeled through state government intermediaries, local government reliance upon state government authority has increased. This has enhanced the leverage state leaders are able to exert upon the local governments typically recruited into growth coalitions and thus, to override opposition to industrial policy.

Again, we see here indications of autonomous state behavior under industrial policy. In contrast to industrial recruitment, which is characterized by the inability of state leaders to override opposition, state leaders are depicted as being able to override the opposition of powerful business groups in their industrial policy interventions.

\section{State Industrial Policy Focuses Public Resources Upon Emerging Sectors of the Economy}

State leaders embraced industrial policy as a response to the industrial displacement of the 1970s and 1980s. State leaders attributed this distress to the inability of traditional industries to compete in an increasingly globalized economy. Recognition that global economic competition would only increase in the future convinced state leaders of the impropriety of focusing their economic development activities upon mature industries. In a break with traditional industrial recruitment activities, which offered public assistance regardless of the type of business activity the beneficiary firm is involved in, state leaders used their industrial policy interventions purposefully to promote only industries in emerging sectors of the economy.

There is a certain equivocation in the literature as to what constitutes an emerging economic sector. In most cases, states have defined emerging sectors of the economy in terms of industries producing capital intensive, high value-added goods 
that demand highly selective occupational skills with prospects for rapid growth in worldwide demand. Massachusetts targeted "technology-based" firms whose products or services are "sufficiently innovative to provide competitive advantage." North Carolina supported businesses doing "research leading to the development of products, processes or services." Industrial policy in Pennsylvania focused state assistance upon electronics and biotechnology enterprises while industrial policy in Michigan is explicitly directed towards promoting technological innovation in the automobile sector. Mississippi explicitly listed fourteen industries eligible for assistance under its Advanced Technology Initiatives Act (Eisinger 1988:269).

Theory posits that the leaders of the autonomous state can override powerful interest groups. An industrial policy focus upon specific industries reflects a state able to make critical choices and hence is indicative of state autonomy.

The Programmatic Choices that Shape Industrial Policy will be Based Upon Objective Analysis

In making the programmatic decisions that shape industrial policy, state leaders appear to be guided not by political considerations but by objective assessments of how public resources can best be used to generate economic growth in different localities (Eisinger 1988; Osborne 1988). Osborne (1988:258-259), for example, notes industrial policy initiatives in Pennsylvania and Michigan were based upon "strategic audits," which "focused in on their economic bases, identified their strengths and weaknesses, and developed initiatives that exploited those strengths and remedied those weaknesses."

Dewar (1986:150) argues that under industrial policy, policy choice must be based upon objective analysis. This is because:

industrial policy aims to select and provide public support for "winners"--industries likely to both provide high economic benefits and 
to flourish in a state's particular environment. Picking winners requires that policy choices be based upon an understanding of the problems facing local economies and the competitive advantage offered by different areas, an assessment of the prospects for future growth in specific industries and the factors that promote industrial growth, why some firms locate in an area while others do not, what state and local government can do to promote sector growth that industry will not do for itself, and what are the opportunity costs of investing public resources in one industry and not another.

Effective information collection and processing is central to the capacity of state leaders to formulate and pursue goals apart from those of dominant private groups. Case evidence depicting state leaders as basing their industrial policy decisions upon objective analysis can therefore be seen as indicative of autonomous state behavior.

State Industrial Policy is Characterized by Concerted Action Amongst the Economic Development Agencies of State Government

Industrial recruitment is characterized by administrative fragmentation amongst public authorities. The organizational arrangements through which state leaders have sought to pursue their industrial policy aims vary with place. Still, as a general rule, state industrial policy interventions are characterized by administrative structures that provide for more cohesive action amongst state agencies. For example, Governor Thornburgh sought to infuse cohesiveness into state industrial policy activity in Pennsylvania by consolidating once autonomous agencies. A similar approach was taken by Governor Thompson in Illinois (Clarke 1986:37; Osborne 1988:43-81). Elsewhere, state leaders have sought to lend institutional cohesion to their industrial policy initiatives by creating select task forces or development cabinets composed of agency heads and other key administration staff. Arkansas is a case in point. Governor Clinton brought together in a task force the heads of state agencies responsible for industrial development, employment security, vocational training, 
housing and higher education. So did Governor Celeste in Ohio (Clarke 1986:30;

Osborne 83-110). In Massachusetts, Governor Dukakis took a different approach to organizing his industrial policy interventions. He appointed a "Development Czar," with responsibility for coordinating seven cabinet level offices (Clarke 1986:39; Fosler 1988; Osborne 1988:175-210). Eisinger credits strategic economic development plans for coordinating the economic development activities of various state agencies in several states. There appears to be little uniformity in terms of the scope of these plans and the process by which they are developed. But according to Eisinger (1988:27-28), the plans serve to "focus resources...on certain targeted industries of special significance..and prevent diffusion of effort."

Whatever particular arrangement prevails, the new institutional arrangements that characterize industrial policy are held to serve two purposes. They are aimed at infusing the state apparatus with the cohesion necessary to objectively collect and process the information upon which the programmatic decisions that state leaders make in shaping industry policy decisions are based. And they allow state leaders to concentrate the effective policy instruments of the state government. Using public resources to exploit indigenous comparative advantage and promote growth at the sector level is a complex task requiring coordination over a wide range of public service inputs. These include harmonizing fiscal, regulatory, tax, education, training programs and investment in infrastructure in a fashion most likely to promote growth in a targeted class of industries (Goldstein 1986:3).

Theory posits that state leaders are more likely to be able to translate their policy preferences into authoritative actions if they are able to exercise concerted control over the complex organizations involved in policy delivery. Industrial policy 
is characterized by cohesive institutional arrangements and is thus indicative of state autonomy.

\section{The Shortfall of Theory}

The literature points to instances in which the leaders of America's state governments appear to be acting autonomously in their industrial policy interventions. The industrial policy literature does not indicate that state leaders act autonomously in all instances, however. For example, some states have focused their industrial policy interventions upon promoting growth in emerging industries. Michigan, Mississippi, Massachusetts and North Carolina have been cited as examples. Others, notably Wisconsin, Maine and Massachusetts, have used industrial policy not to promote growth in emerging industries but to protect declining steel, textile, and automotive industries (Eisinger (1988:307-329). Rhode Island's Greenhouse Compact did aim to identify, select and promote the development of a select group of "sunrise" industries in the technology sector. But the Greenhouse compact also aimed to stabilize older industries that were "losing ground to international competition" (Silver and Burton, 1986:132). Clearly, in practice then, state industrial policy activity is not always focused upon emerging industries.

Evidence depicting state leaders in Massachusetts, Rhode Island and Pennsylvania as having embraced industrial policy in advance of non-state actors and over the opposition of powerful business groups has been cited as evidence of autonomous state behavior. Yet, Lampe (1988) provides convincing evidence that industrial policy initiatives in Massachusetts were shaped less by ideas originating within the administration of Governor Dukakis than by dominant Boston area business interests, especially the First National Bank of Boston. Under the so-called "New Social Contract For Massachusetts," concluded between Governor Dukakis and 
Boston area technology firms, the latter agreed to create 60,000 new jobs in return for favorable tax policies. The Contract is held as a watershed in state industrial policy making. In fact, market forces would have created these jobs anyway, and technology industry leaders.knew this (Lampe 1988:155-156). Did Governor Dukakis actually possess the critical initiative in forging the "Contract," or did it represent a concession to business sector demands? The answer and hence the degree to which the Dukakis Administration possessed autonomy is far from clear.

Strong opposition from Rhode Island business and labor groups was crucial in convincing voters to reject funding for the Greenhouse Compact by a margin of four to one (Silver and Burton 1987:131-146). The Greenhouse Compact was never implemented. According to Osborne (1988:43-81), in Pennsylvania, political pressures forced Governor Thornburgh to extend industrial policy activities aimed at promoting the technology sector to small communities otherwise lacking the inputs requisite to technology industries. This raises questions on the degree to which state leaders have indeed been able to override opposition in forging their industrial policy interventions and on the degree to which industrial policy interventions have been targeted as well.

Nor is it clear that the programmatic decisions that have shaped state industrial policy interventions have indeed been based upon objective factors instead of political expediency. Osborne notes that industrial policy initiatives in Pennsylvania and Michigan were based upon "strategic audits," which "focused in on their economic bases, identified their strengths and weaknesses, and developed initiatives that exploited those strengths and remedied those weaknesses." Dewar (1986) has studied industrial policy making in Minnesota. She concludes that technical analysis played little role in industrial policy decisions. This was because: 
Legislators and the governor wanted visible, newsworthy projects to create jobs, and they wanted many such projects quickly...In the short run, taking any action to try to solve employment problems was more important for political purposes than its actual effect on the regional economy. [Technical analysis] interfered, in part because the visible projects were not necessarily technically or financially feasible, but aiso because analysis took time (Dewar, 1986:152).

In an essay entitled "Industriai policy: A Dissent," Schultze (1983:9) argues that American government is inherently incapable of basing economic development policy choices upon objective criteria. He argued that this was because basing policy choice upon objective criteria required picking winners and losers and:

The one thing that most democratic systems--and especially the American one--cannot do well at all is to make critical choices among particular firms, municipalities, or regions, determining cold-bloodily which shall prosper and which shall not.

In light of this evidence, the autonomy state leaders possess in their industrial policy interventions appears to be above all else, situational, varying with the circumstances and the constellation of forces arrayed in the economic development domain. Unfortunately, the literature as it currently stands does little to define the situations that determine the relative degree of autonomy state leaders possess in their industrial policy interventions. The key problem is the lack of any systematic accounting of how factors peculiar to the political economies of individual states have shaped state industrial policy. For example, among the three major books on state industrial policy, only Eisinger (1988) proceeds systematically from a set of precepts and assumptions. But Eisinger's analysis is based primarily on an aggregate mapping or inventorying of state industrial policy activity, as Anton (1989:340) notes. Because his analysis is based upon aggregate data, he takes little account of how industrial policy interventions have been shaped by forces peculiar to the political economies of different states and hence, the circumstances that define the amount of autonomy state leaders possess. Perhaps more importantly, Eisinger's analysis appears to be driven 
by an a-priori assumption that state industrial policy interventions unfold in practice as designed; he appears to assume that the reality and rhetoric of state industrial policy are one and the same. The tone of his analysis is highly sympathetic. Critical perspective is often lacking.

The contributions offered by Osborne (1988) and Fosler (1988) are case oriented. However, the accounts offered by these contributors are nonsystematic. They proceed from no precepts or assumptions establishing the parameters within which to judge how state industrial policy activities are configured and hence, how much autonomy state leaders possess. This point has been acknowledged by reviewers. For example, Anton (1989:340) credits the value of the "first hand accounts" of industrial policy formulation Osborne offers. Nonetheless, he describes Osborne's contribution as "a work of political journalism, breezy in tone...[which reduces] complicated problems to simple either/or choices." Bollens (1989:244-245) criticizes Fosler in a similar tone, writing that Fosler "frequently approximates a journalistic rather than an analytic style when describing the process of policy formation." Adds Bollens: "Indeed, the writing style is similar in many respects to journalist David Osborne's new book on the same subject."

\section{THE RESEARCH AGENDA}

In what situations do state leaders acquire autonomy in their industrial policy interventions? How much autonomy do state leaders possess in their industrial policy activities? The prominent position industrial policy has assumed on statehouse agendas makes these important and urgent questions. This research tries to provide answers to these questions identifying the variables that determined the amount of autonomy that state leaders possessed in formulating and implementing the Regional 
Strategies program, centerpiece of industrial policy in Oregon during the latter half of the 1980s under the Administration of Governor Neil Goldschmidt.

The Regional Strategies program comprised an excellent case study for this purpose. It's operative arrangements embodied key industrial policy principles. For example, under the terms of Regional Strategies, Oregon's counties were directed to target for promotion an industrial sector with high prospects for future employment growth. Selection of these industries was to be based objective analysis of the strengths and weakness of local economies. Also, Regional Strategies was accompanied by measures aimed at reorganizing and centralizing Oregon state government. Hence, there are ample grounds upon which to base the hypothesis that formulation and implementation of Regional Strategies will evince state autonomy.

$\underline{\text { Research Boundaries }}$

Responsibility for implementation of Regional Strategies was entrusted to Oregon's thirty-six counties. Each was responsible for targeting an industry for promotion. The Goldschmidt Administration encouraged contiguous counties to join together and implement Regional Strategies through multi-county regions. In some instances, two or more counties did join together. In other instances, however, Regional Strategies was implemented by single counties alone. In at least one case, a county first joined with other counties in a multi-county region but later seceded to implement its own unilateral strategy. Table I summarizes the outcome of implementation of the Regional Strategies program. A variety of industries were selected by a number of regions.

To manage this analysis within available time and resources, I decided to narrow my analysis of the implementation phase of Regional Strategies to just three of 
TABLE I

REGIONAL STRATEGIES SUMMARY TABLE

\begin{tabular}{|c|c|c|c|c|c|}
\hline REGION & COUNTIES & STRATEGY & DATE & $\begin{array}{l}\text { LOTTERY } \\
\text { FUNDING }\end{array}$ & $\begin{array}{c}\text { TOTAL } \\
\text { FUNDING }\end{array}$ \\
\hline Coos & Coos & Port & $2 / 18 / 88$ & $\$ 542,680$ & $\$ 5,834,680$ \\
\hline $\begin{array}{l}\text { Central } \\
\text { Oregon }\end{array}$ & $\begin{array}{l}\text { Crook } \\
\text { Deschutes } \\
\text { Jefferson }\end{array}$ & Tourism & $3 / 4 / 88$ & $\$ 715,000$ & $\$ 20,379,174$ \\
\hline Baker & Baker & Tourism & $4 / 8 / 88$ & $\$ 450,000$ & $\$ 6,080,000$ \\
\hline $\begin{array}{l}\text { Oregon } \\
\text { Tourism } \\
\text { Alliance } \\
\text {. }\end{array}$ & $\begin{array}{l}\text { Clackmas } \\
\text { Clatsop } \\
\text { Columbia } \\
\text { Lincoln } \\
\text { Multnomah } \\
\text { Tillamook } \\
\text { Washington } \\
\text { Yamhill }\end{array}$ & Tourism & $7 / 7 / 88$ & $\$ 10,293,065$ & $\$ 115,702,904$ \\
\hline Lane & Lane & Tech Transfer & $8 / 16 / 88$ & $\$ 2,250,000$ & $\$ 22,568,800$ \\
\hline $\begin{array}{l}\text { Southern } \\
\text { Oregon }\end{array}$ & $\begin{array}{l}\text { Curry } \\
\text { Douglas } \\
\text { Jackson } \\
\text { Josephine }\end{array}$ & Tourism & $8 / 22 / 88$ & $\$ 3,089,684$ & $\$ 87,682,997$ \\
\hline $\begin{array}{l}\text { Marion- } \\
\text { Polk }\end{array}$ & $\begin{array}{l}\text { Marion } \\
\text { Polk }\end{array}$ & Agriculture & $8 / 22 / 88$ & $\$ 2,096,110$ & $\$ 3,929,510$ \\
\hline $\begin{array}{l}\text { Linn- } \\
\text { Benton }\end{array}$ & $\begin{array}{l}\text { Linn } \\
\text { Benton }\end{array}$ & Tech Transfer & 12/1/88 & $\$ 1,553,500$ & $\$ 3,278,239$ \\
\hline Malheur & Malheur & Agriculture & $1 / 10 / 89$ & $\$ 315,000$ & $\$ 549,000$ \\
\hline
\end{tabular}


TABLE I

REGIONAL STRATEGIES SUMMARY TABLE (continued)

\begin{tabular}{|c|c|c|c|c|c|}
\hline REGION & COUNTIES & STRATEGY & DATE & $\begin{array}{l}\text { LOTTERY } \\
\text { FUNDING }\end{array}$ & $\begin{array}{l}\text { TOTAL } \\
\text { FUNDING }\end{array}$ \\
\hline Klamath & Klamath & Tech Transfer & 2/1/89 & $\$ 558,462$ & $\$ 9,491,478$ \\
\hline Hood River & Hood River & Agriculture & $2 / 7 / 89$ & $\$ 165,000$ & $\$ 382,000$ \\
\hline $\begin{array}{l}\text { North } \\
\text {.Central }\end{array}$ & $\begin{array}{l}\text { Gilliam } \\
\text { Sherman } \\
\text { Wasco } \\
\text { Wheeler }\end{array}$ & Tourism & $2 / 13 / 89$ & $\$ 735,000$ & $\$ 3,151,165$ \\
\hline $\begin{array}{l}\text { Morrow- } \\
\text { Umatilla }\end{array}$ & $\begin{array}{l}\text { Morrow } \\
\text { Umatilla }\end{array}$ & Agriculture & $3 / 14 / 89$ & $\$ 1,080,000$ & $\$ 11,588,700$ \\
\hline $\begin{array}{l}\text { Hamey- } \\
\text { Lake }\end{array}$ & $\begin{array}{l}\text { Harney } \\
\text { Lake }\end{array}$ & $\begin{array}{l}\text { Secondary } \\
\text { Wood Product }\end{array}$ & ts & $\$ 411,000$ & $\$ 3,698,000$ \\
\hline \multicolumn{6}{|l|}{ Statewide } \\
\hline Total: & & & & $\$ 22,996,821$ & $\$ 268,102,793$ \\
\hline \multicolumn{6}{|l|}{ Notes: } \\
\hline
\end{tabular}


these regions. My criteria for selecting these regions was as follows. Broadly speaking, program implementation produced two different kinds of outcomes. In most cases, Regional Strategies produced collaborative multi-county regions; in other cases, single counties implemented Regional Strategies unilaterally. Also, the overwhelming number of Oregon's counties--twenty-six of the state's thirty-six total counties-implemented strategies targeting tourism. As with the implementation of multi-county strategies, the implementation of tourism strategies emerged as a key Administration preference. Also, widespread implementation of the Regional Strategies program was preceded by a prototype case, meant to serve as a model upon which subsequent strategy efforts could be modeled. To identify the political and economic impulses that led to these divergent outcomes and which point to the circumstances conducive to gubernatorial success, I sought to select cases which resulted both in multi-county groupings and unilateralism, where tourism was and wasn't targeted, and a prototype case. This criteria could best be met by selecting the cases of Central Oregon, Southern Oregon, and Klamath County. Figure 1 depicts the location of these regions.

\section{Methodology}

The record and analysis presented in this dissertation draws upon document research--legislative and other official government documents, newspapers, and other periodicals--and especially upon interviews, conducted with key actors in the Regional Strategies process. I prepared a list of interview candidates upon the basis of reputation--names mentioned in press clippings, official documents and the sort--and subsequently expanded as appropriate through the use of traditional snowball sampling techniques. My analytical approach is inductive, drawing upon interviews and documents as the basis upon which conclusions about the Regional Strategies 


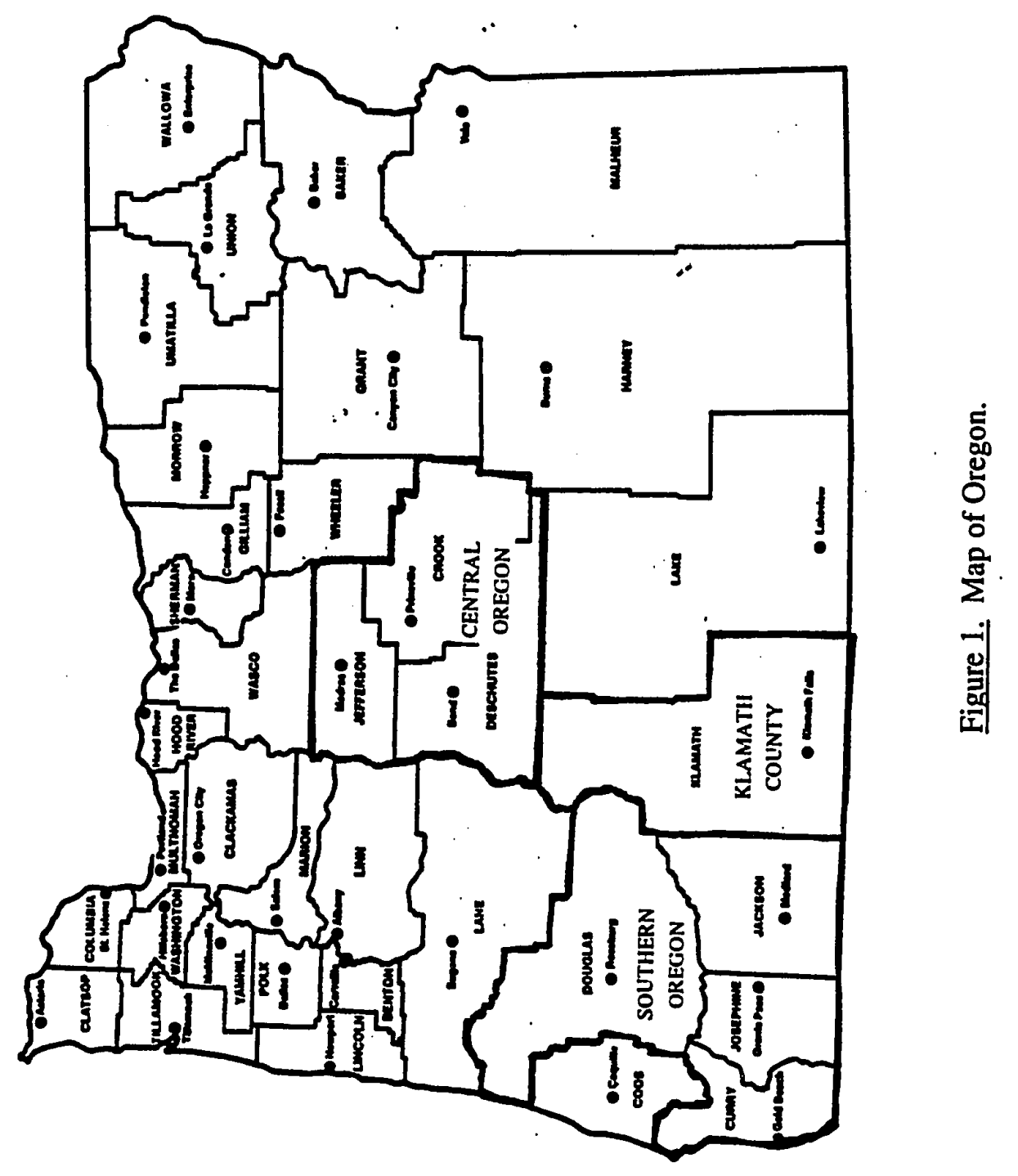


process are drawn. An effort was made to carefully attribute the sources of the information presented herein. Especially in the case of interviews, however, some circumstances were attested to with such frequency that systematic attribution of all sources would involve endless citations. In these instances, only those sources responsible for the initial or principal insight have been cited. When possible, citations drawn from newspapers and other documents are used to corroborate assertions made during interviews. Passages in which no sources are attributed represent the views the writer has drawn from the cited information. 
NOTES

1. For a more detailed discussion of Pluralism and Marxism, see Carnoy (1984), Alford and Friedland (1985), or Held (1987). 


\section{CHAPTER III}

\section{THE IMPULSE TO INDUSTRIAL POLICY IN OREGON}

The Regional Strategies program has its roots in the economic crisis that prevailed in Oregon during the first half of the 1980s. The crisis produced sectionally divergent demands for state economic development intervention. The failure of industrial recruitment's to reconcile these demands fueled calls for state economic development policy reform, providing the impulse to reform proposals incorporating key industrial policy principals.

\section{CAUSES AND CONSEQUENCES OF OREGON'S ECONOMIC CRISIS}

The first half of the 1980s was a period of economic hardship for many Oregonians. Table II helps explain why. Between 1979 and 1981, 100,000 Oregonians lost their jobs. In winter, 1981-82, Oregon's unemployment rate stood at over 11 percent, sixth highest in the nation. Not once in the following four years would Oregon's unemployment rate drop below the national average. In October, 1986, twenty-five of Oregon's thirty-six counties were classified by the U.S. Labor Department as Labor Surplus Areas: counties in which unemployment rates throughout the preceding twenty-four months had exceeded the national average by 20 percent or more. Oregon's per-capita income, which stood slightly above the national average in 1978 slipped by 1984 to only 91 percent (Joint Legislative Committee on Trade and Economic Development 1986). During the first half of the 1980s, businesses in Oregon were more likely to declare bankruptcy than those in almost every other state of the union (Oregonian January 27, 1985). ${ }^{1}$ 
TABLE II

INDICATORS OF ECONOMIC DISTRESS IN OREGON JULY 1979

JAN. 1982

OCT. 1986

$\underline{\text { Unemployment Rate }}^{\mathrm{a}}$

$\begin{array}{llll}\text { United States } & 5.7 \% & 8.5 \% & 7.1 \% \\ \text { Oregon } & 7.4 \% & 11.1 \% & 8.4 \% \\ \text { Portland Metro } & 5.8 \% & 10.7 \% & 6.5 \% \\ \text { Rest of Stateb } & 7.8 \% & 15.2 \% & 9.2 \%\end{array}$

Total Employment, Oregon's Lumber and Wood Products Sector

$\begin{array}{lll}86,900 & 54,500 & 67,400\end{array}$

Number of total 36 Oregon Counties Designated Labor Surplus. Areas ${ }^{c}$

$\begin{array}{lll}\text { N/A } & 22 & 26\end{array}$

Net Population Migration, Oregon, April 1, 1980 Census - July 1, 1986 Estimate

$(-) 89,896$

$\underline{\text { Notes }}$

a Seasonably Adjusted

b State unemployment rate with the three county Portland metropolitan area removed from calculations.

c Labor Surplus Area defined by the U.S. Department of Labor as counties in which unemployment rate exceeded U.S. national average by 20 percent or more.

Source: Oregon Employment Division; Center for Population Research and Census 
Oregon's crisis was largely due to it's heavy dependence upon the wood products industries. In 1979, wood products accounted for over 40 percent of total manufacturing employment in Oregon versus 3.3 percent for the nation as a whole (Commerce Department 1979). No other American state was as dependent upon the wood products industries as Oregon. Most of the lumber, plywood and veneer produced in Oregon was consumed by the building trades. The onset of the 19791981 recession, the worst in the U.S. since the Great Depression, was signaled by a decline in construction activity, leading to a collapse in the demand for Oregon's wood products. With the Federal Reserve pursuing a tight money anti-inflationary policy, building activity remained moribund through early 1982, when interest rates eased, spurring construction activity. The demand for Oregon's wood products rebounded. Yet, although production in Oregon's mill works expanded by over 54 percent between 1982 and 1985, mill work employment increased by less than 15 percent (Timber Operators Council nd; Department of Commerce 1982, 1985).

The reason recovery in output so outpaced employment growth was because as the demand for Oregon's wood products boomed, the mill owners invested heavily in labor saving technologies. In consequence, for many of the thousands of Oregon mill workers who lost their jobs during the decade's first two years, recovery in the demand for wood products meant not a return to work but instead, classification as a displaced worker. Employment in Oregon's lumber and wood products sector dropped from 85,000 to 67,000 between 1979 and 1986. As for those who continued working in the restructured wood products sector, they could expect to be paid a wage in 1985 which, when measured in real terms, averaged some 17 percent below 1979 levels (Employment Division 1985; 1979).

The result was an exodus from Oregon's small cities and rural areas as displaced wood workers and others dependent upon their trade left home to search for 
work elsewhere. Hibbard (1989) estimates that as many as one in four Oregon households experienced major disruption during this period, either through layoff or through having a household member move away to seek work. Lane County, the state's second most populous county and one of the most dependent upon wood products, saw its population decline by almost 10 percent between 1980 and 1986. Between 1980 and 1986, out-migration was so great in coastal Coos County, where the unemployment rate rarely dropped below 20 percent, that the County's population declined by almost 15 percent (Schafer 1987). In fact, all but four of Oregon's thirtysix counties experienced net population out-migration between 1980 and 1986. In consequence, Oregon's population in the latter year was 90,000 less than in the former (Center for Population Research and Census 1987). ${ }^{2}$

In his history of the coastal community of Coos Bay, the mill and log shipping community on Oregon's south-central coast, Robbins (1988:160) depicts the first half of the 1980s as a period in which economic crisis caused an increase in "(the) sexual and physical abuse of children...spousal beatings... alcoholism." The Ministerial Association in the south central Oregon city of Klamath Falls reported that counseling for drug, alcohol, and child abuse increased tenfold between 1980 and 1985 (Keller January 8, 1990). Almost certainly, these types of disorders increased not only in Coos Bay and Klamath Falls, but in other communities as well.

Economic crisis eroded the fiscal resources of Oregon's local governments. Oregon's real estate market was stilled. Property values declined throughout most of Oregon between 1979 and 1985 with the state's total assessed property value in the latter year being some 5 percent less than in the former. Property taxes are the primary source of local government finance in Oregon. Excepting 1982, local property tax collections did not actually decline. But this result was achieved only at 
the cost of significantly higher property tax rates (Department of Revenue nd). In addition to property taxes, county governments in Oregon receive revenues from the U.S. Forest Service and Bureau of Land Management for timber harvested upon federal forest land otherwise exempt from conventional property taxation. For this reason, county government has historically been viewed as an important source of public service delivery throughout much of Oregon. But with fewer trees being cut by the moribund wood products industry, these revenues dropped by almost half (47\%) between 1979 and 1984, when measured in real terms (Forest Service, nd; Bureau of Land Management nd). Statewide, when measured in real terms, local government property tax and timber harvest revenues totaled 8 percent less in 1982 than in 1979 (Department of Revenue nd). Faced with declining revenues, local governments channeled their available resources into maintaining the most visible and personalized services--education, public safety, health, and welfare. Local government expenditures for other purposes were deferred, especially those for capital projects which, when measured in constant dollars, declined by 40 percent between 1981 and 1986 (Seidel 1990).

State finances suffered also. Oregon's system of state government financing is poorly diversified, being overwhelmingly dependent upon personal income tax collections. ${ }^{3}$ In 1979, for example, personal income taxes accounted for over 70 percent of state government general fund revenues (Executive Department 1983). As the recession unfolded and unemployment rolls surged, personal income plunged. So did personal income tax collections. Measured in real terms, personal income tax collections in Oregon were for the 1979-81 biennium only 68 percent of initial projections. The decline in personal income tax collections was accompanied by a reduction in federal transfer payments. Under the Reagan Administration, federal 
contributions to the state treasury declined, with the real value of federal transfer payments to Oregon dropping by 13 percent between 1979 and 1983 . With both tax collections and federal transfers curtailed, real gross state general fund revenues during the 1985-87 biennium were 12 percent less than during the 1979-81 budget period (Executive Department 1985; 1987; 1989). Declining revenues meant curtailed service delivery. Measured in real terms, expenditures by the state transportation and education departments each suffered 11 percent declines between the 1979-91 and 1983-85 budget periods. For Oregon's Adult and Family Services Division, the drop was almost 14 percent (Executive Department 1983; 1987). As a result of budget cuts, Oregon's Employment Division, certainly one of the busiest of public agencies during this period of high unemployment, saw 188 positions eliminated in July, 1984 (Employment Division 1984). State transfers to local governments declined by over 42 percent between the 1979-81 and 1983-85 budget periods (Executive Department $1979 ; 1983)$.

\section{THE FAILURE OF INDUSTRIAL RECRUITMENT}

The onset of economic crisis coincided with the installation of new political leadership in Oregon. Vic Atiyeh first campaigned to be elected Oregon's governor in 1974. He lost, but ran again in 1978. Successful the second time around, he was inaugurated as Oregon's chief executive in January, 1979. He "had the misfortune to take over the statehouse just as the Oregon economy began to disintegrate" (Peirce and Hagstrom 1984:826). Within six months of his taking office, economists at the Oregon Employment Division (OED) began to report signs of weakness in the key mill working and construction sectors. At the end of his first year in office, Labor Trends, OED's monthly publication, suggested that Oregon was going through a 
"transitional period" (Employment Division 1979). The bottom fell out in April, 1980, with Labor Trends reporting that the recession had burst on the scene like a "bull in a China shop" (Employment Division 1980). Layoffs abounded through the winter of 1981-82, when the state's unemployment rate peaked at close to 12 percent.

\section{Oregon as an Administratively Weak State}

The Atiyeh Administration responded to the economic crisis with a program aimed at recruiting industry. Industrial recruitment may have made sense to the Atiyeh Administration. The state government over which the Atiyeh Administration presided throughout the first half of the 1980 s was fiscally weak. It was also administratively weak. In fact, the state government apparatus over which Governor Atiyeh presided may have been one of the most administratively weak of the fifty U.S. state governments. This conclusion is suggested by Abney and Lauth (1985:101-102), who rank Oregon first among the fifty U.S. states in terms of the degree to which state agency heads interact with interest groups. Rueschemeyer and Evans (1985:50-60) and Weir and Skocpol (1985:141-148) cite exactly this type of interaction as a key indicator of weak administrative capacity and government fragmentation.

The administrative weakness that characterized Oregon's state government apparatus was the product of long standing cultural, political and economic tensions. ${ }^{4}$ These tensions have imbued Oregon with a system in which constitutionally mandated checks and balances divide state between the governor, legislature and a number of semi-autonomous public commissions. The balance of power inherent to this arrangement serves to restrain state government intrusion into local affairs and prevents the state's sectional interests from gaining too great an advantage at the expanse of others. But the result is an administratively weak and fragmented state government apparatus in which the executive branch, lacking overall authority, often 
faces difficulties in orchestrating concerted action by state agencies. Lending a practical perspective to the administrative weakness attributable to these circumstances, the Oregonian (November 2, 1989) reported:

the Oregon constitution, with its numerous checks and balances provides for a weak executive. Oregon's inability to remedy several problems...almost certainly [is] mainly the result of constitutional constraints.

Perhaps nothing better exemplified the administrative weakness of Oregon state government than the Oregon Economic Development Department (EDD). The Economic Development Department was created in 1973 as a product of disputes over who should control the state's economic development policy making apparatus. Prior to 1973 , responsibility for Oregon state government's involvement in economic development activities was installed in the Economic Development Division, an integral part of the governor's office and in ad-hoc advisory panels serving at the governor's pleasure. This arrangement gave Oregon's governor broad discretion in determining the scope and substance of state economic development activities. However, this arrangement proved objectionable to key members of the Oregon legislature. Subsequently, a new arrangement was forged, one which removed responsibility for Oregon state government's involvement in economic development from the governor's office, leading to a significant diffusion of this authority.

Legislation passed into law in 1973 created EDD as an independent cabinet level agency of the Oregon state government bureaucracy. A state Economic Development Commission, composed of five members nominated by the Governor and confirmed by the state senate, was also established. The Commission's role was to set state economic development policy. EDD's role was to implement Commission policies. The Commission was also invested with authority for appointing EDD's director and for approving applications for state industrial revenue bond funding. This 
arrangement established the Commission as EDD's governing body. Yet, the Commission's control over EDD was not to be exclusive. The legislation that created EDD also directed the agency to undertake initiatives ordered not only by the Commission but by the governor and legislature as well.

Given the multiple centers of authority to which EDD was seemingly accountable, it is unsurprising that the agency's early history was replete with disputes over exactly who was in charge of the agency--the quasi-independent Economic Development Commission, the Governor, or lawmakers. Perhaps the most important consequence of the disputes that came to surround the administration of Oregon's state economic development policy apparatus were charges that EDD's activities were poorly coordinated with those of other state and local agencies. There was in fact a well founded basis for this charge. During the 1970s, EDD been charged with the task of preparing a statewide economic development plan defining what roles other components of the state bureaucracy could play in fostering local economic growth. The planning effort reflected the recognition that state agencies besides EDD, although having no explicit economic development mandate, nonetheless provided services affecting a community's prospects for economic development. For example, one agency targeted in the 1970s planning effort was Oregon's Department of Transportation (ODOT). ODOT had an implicit role in promoting local economic development since it was responsible for building and maintaining the state's highway system, upon which the efficient movement of commodities depended. To take another example, Oregon's Department of Environmental Quality (DEQ) administered funds used for building and maintaining local water and waste treatment facilities. Again, there was an implicit economic development dimension to DEQ's responsibilities; it funded facilities necessary for supporting industrial development 
and population growth. In fact, the economic development plan EDD set out to prepare during the 1970 s was never completed. Despite the expenditure of perhaps as much as $\$ 1$ million, the planning effort collapsed. In large part, failure was due to EDD's inability to coordinate its planning effort with other elements of Oregon's state government bureaucracy (Slavin forthcoming).

It is clear that there was no easy solution to the obstacle fragmentation posed to coordinated economic development planning in Oregon. For example, Governor Atiyeh's administration was preceded by the administration of Governor Bob Straub; it was Governor Straub who directed EDD to prepare the statewide economic development plan. When a resignation created a vacancy in the top EDD spot in 1977, Governor Bob Straub moved to have his own candidate installed as EDD director. By doing so, he aimed to increase EDD's responsiveness to gubernatorial initiatives and hence overcome problems posed by fragmentation. However, under the terms of EDD's founding legislation, it was the Economic Development Commission, not the Governor that was empowered to appoint the agency's director. Dominated by appointees of the previous administration, the Commission balked at Governor Straub's choice. Straub responded by firing recalcitrant Commissioners. Through this maneuver, he succeeded in installing his own choice as EDD head. Still, its was clear that machinations such as that employed by Governor Straub posed few long term prospects for overcoming the administrative fragmentation afflicting Oregon state government. Vexed that Straub had upset the balance of power initially crafted into EDD's governing arrangements, lawmakers subsequently enacted a law prohibiting the removal of sitting economic development commissioners for any but malfeasant offenses.

It would in fact be wrong to solely blame EDD for the failure of its $1970 \mathrm{~s}$ planning effort. The administrative fragmentation and dispersed authority that 
characterized EDD's governance was systemic, extending to other agencies as well. For example, both ODOT and DEQ were governed under commission arrangements quite similar to that under which EDD operated. In consequence, there existed no absolute authority necessary for bringing the components of Oregon's fragmented state apparatus together around a common goal. Indeed, given these circumstances, it would have been somewhat amazing had EDD succeeded in completing the statewide economic development plan that it set out to prepare during the 1970 s.

\section{The Two Oregons}

To recruit investment to Oregon, Governor Atiyeh made a series of highly publicized overseas trips. Included were visits to Taiwan, Japan, and South Korea. Some sense of the efficacy of the Atiyeh Administration's industrial recruitment campaign can be gained from the following information. Industrial Revenue Bonds (IRBs) were the chief incentive offered by Oregon in seeking to recruit investment to local communities. There was an increase in IRB activity under the Atiyeh Administration. At $\$ 98.2$ million, the sum total of IRB issues in 1984 alone was more than double the $\$ 41.3$ million total for the four year period $1976-1979$. During the Atiyeh Administration's tenure in office, Oregon issued \$354 million in IRBs to firms which, in aggregate, promised to create 6,358 new jobs (EDD nd). A report prepared for the Oregon legislature in 1985 found, however, that firms receiving IRB funding between 1980 and 1985 created only one-fourth the number of jobs initially promised (Joint Committee on Trade and Economic Development 1985). Furthermore, these jobs were not uniformly distributed.

After hovering above ten percent for most of the preceding two and a half years, Oregon's statewide unemployment rate finally began to decline in the Spring, 1982. But job growth was concentrated in the diversified economy of the Portland 
metropolitan area. Although the Portland metropolitan area accounted for just half of Oregon's total population, it generated two-thirds of the 68,000 jobs added statewide between 1982 and 1985 . The result was a growing disparity between the economic fortunes of Portland area residents, on one hand, and most of those living elsewhere in Oregon. Unemployment statistics help illustrate this. In December, 1984, the unemployment rate in metropolitan Portland was, at 7.5 percent, only slightly above the national average of 7.2 percent. If Portland was removed from calculations, however, Oregon's unemployment rate swelled to 11.4 percent (Employment Division 1985). Job growth bolstered Portland area government tax revenues. If Portland area local government revenues are removed from calculations, real local government property tax and timber revenues were 24 percent less in 1982 than in 1979. With Portland area governments excluded, real local government revenues did not recover to 1979 totals until 1985 (Department of Revenue nd) Economic bifurcation only . became more pronounced as Oregon neared mid-decade, prompting the Oregonian (January 27, 1985:A1) to report "Oregon's economy is rapidly becoming two. There is the Portland area, and there is everything else."

The Atiyeh Administration's industrial recruitment campaign exacerbated Oregon's economic bifurcation. Between 1980 and 1985, Oregon issued a total of $\$ 267.43$ million in IRBs. Six counties accounted for $\$ 167$ million or 62.5 percent of this total: Multnomah, Washington, Clackamas, which comprise the Portland metropolitan area, and Marion Benton, and Linn--mid-Willamette Valley counties with diversified economies revolving around agriculture, government, education and manufacturing. These three Willamette Valley counties closely trailed the Portland area in recovery. Only $\$ 100.3$ million, or 37.5 percent of IRB funding during this period went to counties east of the Cascade Mountains or south of the Willamette 
Valley, where economic conditions were most distressed. And of this total, $\$ 4.7$ million went to Hanna Nickel in 1985, a Douglas County ore smelter which nonetheless closed down two years later. Another $\$ 31.5$ million of this total was used for mill retrofits which may actually have reduced employment in the mill sector even as the demand for wood products was increasing (EDD nd). 5

If the literature on industrial recruitment is to be believed, IRB funding most probably favored the Portland and mid-Willamette Valley areas because they were intrinsically attractive to business. These areas comprised large markets with a diversified labor supply, easy airport access, universities and a well developed transportation grid. Still, realization that IRB funding--the core instrument of the Atiyeh Administration's industrial recruitment program--primarily benefited Oregon's most developed areas fueled a widespread consensus that the state's economic development needs exceeded what industrial recruitment could accomplish.

\section{Labor's Disaffection}

A good place to begin examining the attitude of Oregon's labor movement towards the Atiyeh Administration's economic development policy is with a white paper titled "reclaiming Oregon's economy," published by the Oregon AFL-CIO in 1982. Decrying that "Urban growth areas have received $79 \%$ of IRB investment in Oregon," and that IRBs "tend to promote investment in the more developed and economically secure areas of the state, rather than in less developed areas where investment is needed," the report attacked the Administration's focus upon industrial recruitment. 6 That union criticism of Governor Atiyeh's program reflected the proclivity of IRB funding to be focused upon Oregon's most developed areas is perhaps unsurprising. Oregon's labor movement was heavily rooted in the wood 
products sector and union membership, heavily concentrated in the state's timber dependent small cities and rural areas.

In "Reclaiming," Oregon's labor movement report went on to argue that "a silicon chip factory...does not salvage the plywood mills whose housing orders are drying up" and shortly thereafter, posed the question, in regard to ventures targeted for recruitment to Oregon, "Do the private sector firms...pay wages as high as those to which Oregon workers are accustomed as a result of forest products past high profitability?" The reference here was to another labor grievance. According to former Oregon AFL-CIO Secretary-Treasurer Bob Baugh (October 23, 1989), Oregon's labor movement saw the Atiyeh Administration's economic development activities as being aimed mainly at recruiting high technology investment to Oregon. As union leaders saw it, the jobs materializing from Governor Atiyeh's recruiting efforts were unlikely to be high wage positions in unionized industries. Instead, they viewed the industrial recruitment effort as most likely to generate the type of low wage, non unionized assembly jobs often associated with electronics assembly. There is an implicit concern with work force bifurcation expressed here which, taken in historical context, has often been construed as threatening labor movement solidarity. Concomitant with his efforts to recruit business investment to Oregon, Governor Atiyeh sought to reduce taxation and regulation of business. When interviewed, Governor Atiyeh (April 30, 1991) said that he viewed such relief, aimed at improving Oregon's business climate, as necessary if his industrial recruitment campaign was to succeed. Under the aegis of improving Oregon's business climate, Governor Atiyeh vetoed a bill which would have expanded state workmen's compensation benefits, a key union goal. But perhaps no other incident caused as much animosity between Oregon's labor unions and the Atiyeh Administration as the 
battle over the plant closing bill during the 1981 session of the Oregon legislature. The bill's central provision would have required firms with over 100 employees to provide advance notice of large scale work force curtailments and layoffs. With union members being laid off in record numbers, the bill was strongly backed by Oregon's labor movement. Oregon's business community vehemently opposed the bill. Governor Atiyeh believed that prior notification would discourage business investment in Oregon and drive away businesses already located there. He saw prior notification as a threat to his business climate campaign and led opposition to this, the most controversial of the bill's provisions. Other less controversial provisions of the plant closing bill became law. The prior notification provisions never did.

In 1982, Governor Atiyeh charged a Blue Ribbon Commission with identifying ways of improving Oregon's business climate. The commission was composed of business leaders; the panel lacked union representation (Oregonian April 25, 1982). That the unions went unrepresented on the commission highlighted another feature of the Atiyeh Administration's economic development policy vexing to the unions; Governor Atiyeh (April 30, 1991) believed that direct labor participation in fashioning his administration's economic development policy would undermine his industrial recruitment program by discouraging business investment in Oregon. From AFL-CIO Secretary-Treasurer Bob Baugh's perspective, the Atiyeh Administration was denying Oregon's labor movement a consultatory role in shaping his economic policy at a time at which its ranks were being devastated by record layoffs.

At best, Oregon's labor movement viewed the Atiyeh Administration's economic development program as punitive. At worst, the labor movement viewed it as a deliberate attempt at union busting. In light of this, it is unsurprising that Oregon's labor movement emerged as probably the most vehement critic of the Atiyeh 
Administration's economic development policy. Oregon AFL-CIO President Irv Fletcher made this point when he was quoted in the April 19, 1983 edition of the Oregonian as saying "Sure I think Vic really believes he has been pro-labor in his political career. Only the record doesn't show that." The same edition of the Oregonian reported that relations between Atiyeh and the AFL-CIO leader had become so strained that the two refused even to speak to each other.

\section{Business Sector Criticism}

A headline appearing in the October 19, 1982 edition of the Oregonian read: "Business Not Hedging: The Whole Bet Is On Atiyeh." Without doubt, Governor Atiyeh was the candidate of choice among Oregon's business community in the 1982 gubernatorial elections. Business support for Atiyeh was in part due to the role his opponent, Democratic State Senator Ted Kulongoski, had played in sponsoring the prior notification provisions of the plant closing bill. With strong business sector backing, Governor Atiyeh raised over $\$ 1.1$ million for his 1982 reelection bid, twice what Kulongoski raised (Oregonian November 2, 1982:A1). Deep pockets helped Governor Atiyeh win 62 percent of votes cast in Oregon's 1982 gubernatorial election, giving him the largest winning percentage in an Oregon gubernatorial race since Mark Hatfield won a second term as Oregon's governor in 1964 (Oregonian November 4, 1982:A1).

Governor Atiyeh's efforts to relax taxation and regulation of Oregon businesses received widespread support from all sectors of Oregon's business community. Still, especially during his second term in office, Governor Atiyeh increasingly found himself in the position of having to defend his economic development policy from criticism by key elements of Oregon's business leadership. In fact, just nine months into his second term, he found himself doing so. The 
occasion was the September, 1983 annual conference of the Associated Oregon Industries, Oregon's main business lobby. Covering the conference, the Oregonian reported:

Governor Vic Atiyeh took off his coat and rolled up his sleeves Friday in defending his economic development program before business and industry leaders, some of whom have been critical of his efforts. "You have undoubtedly noticed, as I have, some business leaders questioning the states economic development program [he said] (Oregonian September 24, 1983).

The criticism against which Governor Atiyeh defended himself at the AOI conference was the product of splintering among regionally based factions the Oregon's business community and the Atiyeh Administration's failure to accommodate competing business sector economic development agendas that emerged as a consequence. At the root of this splintering were the territorial inequities endemic to Governor Atiyeh's industrial recruitment effort. 7

The Portland area had begun growing out of the recession by the time Governor Atiyeh's second term began. More so than anything else, it was the expansion of Oregon's high technology sector, centered in Portland's west side suburbs, that fueled metropolitan area growth. Securing increased funding for higher education emerged as a key aim of west side technology businesses. On another level, economic expansion encouraged a coalition of metropolitan area business and government leaders to embark upon an ambitious effort to attract additional capital investment to the area. At the core of the coalition's agenda was a plan to construct a Convention Center in Portland's city center.

Governor Atiyeh's industrial recruitment program and the agenda of Portland's business interests were highly collateral. Portland's growth coalition sought to attract new capital to the area: as noted earlier, the Portland area was the most likely destination for capital recruited to Oregon by the Atiyeh Administration. 
Governor Atiyeh also emphasized the importance of higher education in his economic development program. Witness, for example, comments the Governor delivered amidst a special 1982 session of the Oregon legislature, one of four such sessions called that year to deal with recurrent budget shortfalls. Speaking before Portland's City Club, Governor Atiyeh "stressed the importance of graduate programs in science and technology at state colleges and universities as an incentive for new business to locate in the state" (Oregonian January 30, 1982:A13).

In contrast to metropolitan Portland, Oregon's timber dependent communities continued to experience not an influx but an exodus of capital during this period. Making reference to Governor Atiyeh's forays to recruit overseas investment, John Mitchell, the U.S. National Bank Vice-President, commented in 1985 that "the major foreign investments won't hit the rural areas" (Oregonian January 27, 1985). Business leaders from Oregon's small cities and rural areas recognized that few if any of the firms accepting Governor Atiyeh's invitation to open shop in Oregon were likely to choose to do so in their own distressed communities.

Oregon has traditionally had a large small business sector: an official from the Oregon Economic Development Department once called Oregon "the number 1 small-business state in the country," with more small businesses per-capita than any other state" (Oregonian January 16, 1989). It is in Oregon's small cities and rural areas that small businesses are especially prevalent. Small city and rural area business leaders developed an economic development agenda apart from that of Portland's business community. This agenda included calls for direct state financial assistance to small business owners. Also included on this agenda was a plan, offered by non metropolitan lawmakers during the 1985 session of the Oregon legislature, to hire a private contractor to run 12 regional "Buy Oregon" projects. These would have been 
aimed at promoting purchases of business commodities from local rather than out-ofstate suppliers. Backers of "Buy Oregon" aimed to have the program administered by an independent contractor. They appear to have aimed to establish a parallel economic development apparatus to that administered by the Atiyeh Administration, which they saw as too committed to an industrial recruitment program favoring the Portland area, one which would more closely pursue their own economic development objectives. According to the Oregonian (November 20,1985), members of the Atiyeh appointed Economic Development Commission opposed "Buy Oregon" because they thought it would harm those Oregon businesses that sold products to other states.

The first half of the 1980s was a period of pronounced economic bifurcation and a scarcity of public resources in Oregon. These circumstances fueled conflicts over state economic development policy, differences which affected Oregon's business community and fueled the type of criticism Governor Atiyeh had to defend himself against at the 1983 AOI conference.

\section{Early Industrial Policy Proposals}

Disaffection with Governor Atiyeh's economic development program fueled calls for reform. The two most prominent were articulated by the Oregon AFL-CIO and by the City Club of Portland, a private, non-profit association composed of executives, professionals and academics drawn from Portland metropolitan area business, civic, education, and government circles.

Recall the 1982 "Reclaiming" document in which Oregon's labor movement attacked the Atiyeh Administration's economic development policy. "Reclaiming" went further, articulating the labor movement's agenda for reforming state economic development policy along lines commensurate with its own goals. This agenda was posed around the following question: 
What projects can re-employ a large number of skilled and semi skilled workers, at or near their accustomed wage, taking maximum advantage of the area's concentration of forest products capital stock, labor force training, the state's existing resources, and location? (AFLCIO 1982)

The AFL-CIO's answer was expressed in a call for state economic

development policy reform described in the "Reclaiming" report as a "comprehensive, fair and sound approach to planning Oregon's economy" (AFL-CIO, 1982). The essence of this reform package is perhaps best captured in the following provisions:

Oregon needs a state wide economic development policy which is coordinated both administratively and geographically to deal with job death (closures) as well as job birth (the attraction of new industry).

Implementation of this policy requires a greater level of communication between related administrative departments than currently exists. Departments such as the Bureau of Labor and Industries, the Employment Division, the Department of Economic Development, the Apprenticeship and Training Division, and other departments dealing with facility siting, land use planning, etc., need to coordinate information gathering and the generation of a rational program for industrialization.

There is also a need for better communication and coordination between state agencies and major constituencies outside of the government, (such as organized labor and community based organizations).

Greater incentives could be provided to encourage the investment of new capital in economically depressed areas. This would help to preserve those communities which have been the most devastated by the declining economy.

The City Club is a private, non-profit association composed of executives, professionals and academics drawn from metropolitan area business, civic, education, and government circles. Normally, the City Club functions to evaluate, debate, and advocate policy options for guiding Portland's future development. In late December, 1983, however, the City Club published a report premised upon the view that "Economic Development in Portland is more than a Portland metropolitan issue. It 
involves policies and actions at the state level also" (City Club of Portland 1983:148). With the publication of the 1983 document, entitled "Report on Economic Development Coordination," the City Club broadened the scope of its involvement to include a review of the Atiyeh Administration's economic development policy.

The City Club's 1983 "Report" was based upon interviews with nineteen persons. Oregon AFL-CIO Secretary-Treasurer Bob Baugh was one of those interviewed. However, more so than anyone else, the report appears to have articulated the views of Oregon's business leadership. At least thirteen of the nineteen people interviewed during preparation of the "Report" could be said to be directly representing private businesses interests, including some of Oregon's largest corporations: First Interstate Bank of Oregon, Pacific Power and Light Company, the Burlington Northern and Southern Pacific Railroads, Portland General Electric Company, and Tektronix, Inc. An officials from Norris, Beggs and Simpson, one of Oregon's largest commercial property brokers also contributed to the "Report" as did representatives of the Portland Chamber of Commerce and the Sunset Corridor Association, which often functioned as a trade association for the technology industries located in Portland's rapidly growing west side suburbs. 8

The City Club report endorsed the Atiyeh Administration's efforts to demonstrate that "Oregon is open for business," this being a metaphor for its business climate measures. Otherwise, the "Report" called for the Atiyeh Administration to adopt certain state economic development policy reforms. Most notably, the report called for Governor Atiyeh to assume a leading role in establishing in Oregon some sort of system of industrial targeting. It called for Atiyeh to personally assume leadership of the state Economic Development Commission and use this post to build consensus over the: 
relative emphasis that should be placed on...large or small companies and traditional businesses in forest products, agriculture and tourism or new types such as computer and genetic engineering business (City Club of Portland 1983:157).

The "Report" further called upon Governor Atiyeh to develop a:

strategy for economic development which unites public and private efforts at the state and local level in ...(1) in day-to-day site processing (tactical activities), (2) in long-range public and private budgeting to encourage economic development (strategic activities), and (3) in setting ultimate goals by which strategies may be planned and tactics

implemented (City Club of Portland 1983:155; 157).

The AFL-CIO and City Club reports are notable because they show Oregon's labor movement and business leadership--key constituencies with strong interests in state economic development policy--proposing state economic development policy reforms embodying key industrial policy principles: planning, the institutional consolidation of state economic development activities, and industrial targeting. This is not to say that these two important constituencies had arrived at any consensus over a reform package, however. They remained divided over important issues. To take the most obvious, the City Club report signalled the business leadership's endorsement of more permissive business climate measures, anathema to labor.

Governor Atiyeh appears to have paid little heed to these calls for reform of state economic development policy. A report contained in the January 7, 1984 edition of the Oregonian helps make this point. It summed up Governor Atiyeh's reaction to the call for economic development policy reform contained in the City Club bulletin by reporting "Atiyeh, is ignoring the report." Commenting upon the reports recommendations, Governor Atiyeh said "It's hard for me to see how they arrived at that conclusion." By all indications, he remained committed to industrial recruitment, a point brought home several days earlier when, commenting on his Administration's record on economic development, he cited "20 companies that have contacted the 
department of economic development about possibly locating in Oregon. The likelihood of getting all 20 is not good," Governor Atiyeh said, "but I can assure you that there will be some companies coming here" (Oregonian January 5, 1984:F3).

\section{Erosion in Public Confidence}

Tensions surrounding state economic development policy in Oregon during the first half of the 1980 s came to a head in meetings of the Oregon state legislature. Throughout this period, Governor Atiyeh and lawmakers from the Democratically controlled legislature battled over economic development policy. The 1985 legislative session saw the debate over state economic development policy become unusually rancorous. The session began with Oregon State Senate President John Kitzhaber outlining the following priorities for legislative attention: "the declining quality of jobs in Oregon; problems of dying communities; the lack of development in rural areas; enhancing the role of small business; exploiting areas in which Oregon enjoys advantages over other states; and development of industries that engage in national and international trade" (Oregonian January 26, 1985). Not long thereafter, however, Governor Atiyeh defended his industrial recruitment program before the Oregon Legislature's Joint Committee on Trade and Economic Development (T\&E). In a seeming rebuke of efforts to expand state economic development policy beyond industrial recruitment, he argued that state economic development resources "should be used for one time events and not for continued funding of state government programs" (Oregonian January 5, 1985). This led Vera Katz, the Speaker of the Oregon House of Representatives to complain that the Atiyeh Administration's economic development policy "could wind up increasing the economic disparity between Portland and rural Oregon." Katz went on to call economic development 
policy under Atiyeh "a collection of isolated and disconnected tactics searching for a strategy" (Oregonian February 22, 1985:C2).

Katz's use of the word "strategy" is instructive. Senate President Kitzhaber and Senator Joyce Cohen, head of the legislature's T\&E committee also spoke repeatedly of an economic development strategy during the 1985 legislative session, revealing that, Governor Atiyeh aside, the call for a systematic reform of state economic development policy had penetrated to the highest levels of Oregon state government. Yet, it would be wrong to conclude that Oregon's legislative leadership had reached consensus on a reform package. No consensus existed, as the Oregonian reported in its edition of January 26, 1985.

In November, 1984, Oregonians established a statewide lottery, the proceeds of which were dedicated to economic development. The lottery was the product of a ballot initiative. Voters, frustrated with Salem's inability to devise an effective response to the state's economic bifurcation, had elected to bypass the legislative process. The lottery was no panacea to the state's economic development problems, however. Instead, the lottery embroiled Governor Atiyeh and legislators in disputes over how lottery proceeds would be spent which, feared House Speaker Katz, could "degenerate into a economic blood feud between Portland and the rest of Oregon" (Oregonian February 22, 1985:C2).

Governor Atiyeh's second term in office expired in January, 1987. Constitutional provisions prohibited him from seeking reelection to a third term as Oregon's governor. The evidence suggests, however, that he would have done poorly had he been able to seek reelection. Forty percent of respondents to a public opinion poll by published by the Oregonian on January 5, 1986 rated Governor Atiyeh negatively. Information on the approval ratings of Governor Atiyeh's predecessors 
was unavailable. But given that Governor Atiyeh won reelection in 1982 with the largest victory margin in twenty years, the results of the 1986 poll could only be construed as reflecting a significant decline in public confidence in his administration. The poll showed the Oregon legislature to have been held in even lower esteem, with a 44 percent negative rating. Public's confidence in Oregon's political leadership was eroding. At the heart of this erosion in confidence was its perceived failure to remedy the problems posed by the state's bifurcating economy. Governor Atiyeh may have tacitly admitted as much when, in his last year in office, he told the Oregonian (April $22,1986)$ that economic development would be the leading issue when voters went to the polls in November, 1986, to choose his successor as Oregon's chief executive.

\section{SUMMARY}

The recession of the early 1980 s plunged Oregon into economic crisis. The diversified urban economy of metropolitan Portland entered a period of growth while crisis conditions continued to prevail in many of Oregon's timber dependent small cities and rural areas. Industrial recruitment not only failed to narrow the growing disparity between the "two Oregons" but appeared likely to actually contribute to this disparity. The inability of industrial recruitment to accommodate the sectionally divergent economic development policy aims spawned by economic bifurcation led Oregon's AFL-CIO and business leadership to propose economic development policy reforms revolving around economic development planning. Badly divided, Oregon's political leadership proved unable to translate calls for reform into a practical reform

program. Failure to do so eroded public confidence in the state's political leadership. More so than anything else, it was political conflict that highlighted the failure of industrial recruitment in Oregon. The literature says nothing about 
industrial recruitment engendering political conflict, identification of the conflict that arose from the use of industrial recruitment in Oregon appears to be a significant and previously unexplored finding. This point will receive further elaboration in the concluding chapter. 


\section{NOTES}

1. Unlike the first half of the 1980 s, the 1970 s were a period of rapid growth for Oregon. Between 1970 and 1980, both the state's population and gross manufactured output expanded by over 25 percent (Secretary of State 1985-87). In a decade in which Oregon's population and economy expanded rapidly, public interest focused upon controlling growth and protecting the environment. During the 1970 s, Oregonians passed laws expanding public park lands, requiring deposits on recyclable pop and beer bottles and cans, and establishing the most comprehensive system of statewide land use planning in the nation.

2. The four counties were Jackson and Josephine, located in southwestern Oregon, Lincoln County, located on Oregon's central coast, and Washington County, which comprises the west side of the metropolitan Portland area.

3. Oregon's voters have repeatedly refused to adopt a sales tax. As of 1989, voters in Oregon had defeated ballot proposals to establish a statewide sales tax on eight separate occasions.

4. This is because IRB funding can be used only to make capital improvements, including facility construction and the procurement of machinery, and not to meet operating expenses such as wages. The propensity for most businesses is therefore to use IRB funding to install labor saving technologies (Litvak and Daniels 1979).

5. As regards the administrative fragmentation characteristic of Oregon, some historical perspective is helpful. Oregon's early settlers came from New England. They brought with them a strong sense of localism and aversion to centralized authority (Peirce and Hagstrom 1983:821-824). According to Elazar (1972:85-110), these attributes are intrinsic to the "Moralistic" political culture with which Oregon is infused. He argues that a fundamental tenet of "Moralistic" political cultures is the problem of reconciling "localistic communitarianism with government bureaucracy."

Oregon is a large state--its 96,699 square miles make it the tenth largest in the United States--divided by high mountain ranges, rivers, broad valleys and vast high desert plateaus and basins. Oregon's size and complex geography have traditionally impeded travel and communications between communities. Territorial diversity has also engendered regionally differing modes of economic production in Oregon: farming in the Willamette Valley, ranching and irrigated agriculture in the eastern desert areas, fishing on the coast, and wood products all over but especially in the southwest. According to Terence O'Donnell (November 8, 1989) Oregon's geography acts as a centrifugal force, dividing regions and communities and feeding localistic tendencies. The centrifugalness, localism and aversion to central authority traceable to Oregon's early settlement and territorial diversity are manifest is what Peirce and Hagstrom (1983:821824) call the "Oregon System."

Rarely has the "Oregon System" been manifest as it was during the early years of the 20th century, when collusive practices between large landholding railroads, bankers, land speculators and Oregon's political leadership fueled a strong political reform movement. The opening salvo was fired in 1902 when Oregonians adopted, by an 
11-1 ratio, the ballot initiative and referendum. In doing so, "Oregon citizens appropriated to themselves... the final decision on virtually all momentous decisions." Subsequently, "in six elections, starting with 1904, Oregon voters expressed their will on 107 specific constitutional or statutory proposals" The result, according to political scientist Frederic C. Howe, was to make Oregon "the most complete democracy in the world" (Peirce and Hagstrom 1983:824-825). In practical terms, this meant a highly fragmented state government structure in which power was widely diffused.

6. Because it is unclear how the AFL-CIO defined developed areas, the writer is unable to account for the discrepancy between the AFL-CIO's 79 percent figure on IRB funding and the six county 55 percent figure offered earlier by the writer.

7. Analysis in this section draws upon interviews I conducted with prominent Oregon business leaders. Included were Richard Reiten (February 27, 1990), former head of the Portland office of the prestigious business consulting firm Arthur Anderson and Company and at the time of this writing, President of Portland General Electric Company, the investor owned utility providing service throughout Portland and much of its surrounding area. Also interviewed were David Bolander (November 22, 1989), President of the Pacific Power and Light Company, the Fortune 500 utility that serves much of the rest of Oregon, John Mitchell, Vice-President of U.S. Bank of Oregon (November 13, 1989), Oregon's largest bank, and Rob Miller (December 21, 1989), President of Mount Jefferson Farms and a key leader of the Willamette Valley business community.

8. The following list of persons interviewed in preparation of the 1983 City Club "Report on Economic Development Coordination" helps cast light on the degree to which it reflected the view of Oregon's business leadership:

Bob Baugh, Secretary-Treasurer, Oregon AFL-CIO.

Floyd Bennett, Vice-President for Corporate Affairs and Economic Development, First Interstate Bank of Oregon.

James Burke, Executive Director, Council for Economic Development in Oregon.

Larry D. Campbell, Vice-President, Plantek.

Robert H. Domries, Burlington Northern Railroad.

Jacob Fried, Portland State University.

Jim Gardner, Chairman of the Joint Legislative Committee on Trade and Economic

Development of the Oregon Legislature.

Louis P. Growney, Industrial Development Director, Pacific Power and Light Company. Clifford Hudsick, Director of Economic Development Services, Port of Portland. Sharon Kafoury, Executive Director, Portland Chamber of Commerce.

Allan R. Mann, Oregon Economic Development Department, Portland Region. Jack McConnell, Norris, Beggs and Simpson, Realtors.

Alan Mellis, Director of Economic Development, Portland General Electric Company. Duane Moore, Southern Pacific Rail Road.

Jack Nelson, Mayor, Beaverton, Oregon.

Steve Peterson, Manager, Business Development Division, Portland Development

Commission.

John Rees, President, Sunset Corridor Association.

Richard D. Smith, Tektronix Inc.

Rodney Stubbs, President, Plantek. 


\section{CHAPTER IV}

\section{BUILDING SUPPORT FOR INDUSTRIAL POLICY}

The role state actors played in bringing industrial policy to Oregon was less one of originator of new policy ideas than one of seizing upon and mobilizing political support for principles first articulated by private non-state groups. New political leadership embraced industrial policy as a vehicle for promoting economic restructuring and more immediately, as a vehicle for fashioning an electoral coalition between groups which, divided by other differences, nonetheless shared a common interest in industrial policy reform.

\section{INDUSTRIAL RECRUITMENT REPUDIATED}

Oregon's 1986 gubernatorial election matched Democrat Neil Goldschmidt against Republican party nominee and outgoing Oregon Secretary of State Norma Paulus in a race the Oregonian (November 5, 1986:A1) described as having been decided on the basis of who voters felt "could best change the state's economic fortunes." 1 According to Goldschmidt campaign planner David Bragdon (October 31, 1989), Goldschmidt entered the race for governor in order to address what he viewed as Oregon's leading economic development challenge. ${ }^{2}$ This was the growing disparity between the economic fortunes of metropolitan Portland and Oregon's distressed timber dependent areas. Since the Portland area appeared to have few problems in attracting investment on its own account, this challenge boiled down to renewing the economies of Oregon's timber dependent small cities and rural areas. 
Gubernatorial aspirant Goldschmidt's views on state government's role in promoting economic restructuring in Oregon was shaped by key limitations. One pertained to the role the U.S. federal government played in Oregon's economy. State government had little control over logging on federal forest lands, where most of Oregon's timber supply was drawn. Oregon also had no authority over foreign trade. Oregon could neither regulate yields on federal forest lands nor prohibit the export of raw logs, hoping to increase log supplies to the mills, creating jobs and boosting tax receipts. Similarly, Oregon had no control over U.S. monetary policy and therefore could not lower interest rates with the aim of stimulating home building and the demand for wood products, again with the hope of boosting employment and taxes. Another limitation pertained to the dominant position private investors play in determining the conditions under which capital is invested in the United States. Even if Oregon state government could have increased log supplies, prohibited log exports or lowered interest rates, Goldschmidt recognized that there was little state government could do to prevent privately owned mill works from increasing production by expanding automation instead of hiring more workers and thus, undermining efforts to revitalize timber dependent economies. In light of these circumstances, Goldschmidt believed that Oregon's wood products sector would only decline in its ability to provide for the economic viability of timber dependent communities. Consequently, he believed that revitalization of Oregon's distressed timber dependent communities required that they reduce their dependence upon wood products by diversifying into new economic activities.

Campaign planner David Bragdon said that from the campaign's earliest days, Goldschmidt recognized that as a vehicle for promoting economic diversification, "more of the same wouldn't do." He was referring to the type of 
industrial recruitment program at the heart of Governor Atiyeh's economic development policy, which experience showed was unlikely to direct investment to timber dependent areas but instead, to Oregon's most highly developed areas. Goldschmidt's repudiation of the Atiyeh Administration's economic development policy was immediate and unequivocal. In late May, 1985, for example, he began a ten city tour of Oregon, the purpose of which was to "help him decide whether he wants to be a candidate for governor of Oregon in 1986." His first stop was in Coos Bay, a timber dependent community experiencing 20 percent unemployment. Speaking before business and labor groups, Goldschmidt attacked the Atiyeh Administration's economic development program for its "lack of focus" and its "neglect of Oregon's timber dependent communities" (Oregonian May 29, 1985:B2). Goldschmidt's attacks upon Governor Atiyeh's economic development record became increasingly virulent as the campaign progressed to the point where, appearing before Portland's City Club one month before the election, he called Governor Atiyeh's economic development policy "an absolute travesty" (Oregonian October 4, 1986).

\section{BUILDING AN INDUSTRIAL POLICY COALITION}

At the heart of the Goldschmidt campaign's election platform was a plan to reform state economic development policy. The Goldschmidt campaign's embrace of economic development policy reform was driven by two principal aims. One was to provide a service which the private sector was unwilling or unable to provide of its own accord--inducing economic restructuring in Oregon's less developed regions. The Goldschmidt campaign's embrace of economic development reform was also driven by political exigencies. Goldschmidt's campaign platform served as the basis 
for the recruitment of an electoral coalition which carried Goldschmidt to success in Oregon's 1986 gubernatorial election.

\section{Seeking the Rural Vote}

The Goldschmidt campaign made a concerted effort to win the support of Oregon's rural voters, who by all accounts, benefited little from the Atiyeh Administration's industrial recruitment program. Prior to entering the race for governor, Goldschmidt's sole experience with elected office was as city commissioner and mayor in Portland. He had never held statewide office in Oregon. He also had a decidedly liberal reputation. So did voters in Multnomah County, which in 1986 accounted for half of all voters in the three county Portland region. Few analysts doubted that in his bid to be elected governor, Goldschmidt would win the Portland vote. Outside of Portland, Goldschmidt's grip on the electorate was much more tenuous. According to Terrence O'Donnell (November 8, 1989) of the Oregon Historical Society, Oregon's small cities and rural communities tend to be politically conservative. Small and rural community voters have also traditionally seen themselves as being dominated by Portland. In consequence, they have often proved reluctant to elect Portland area candidates to statewide office. Goldschmidt's general election opponent, Norma Paulas, had risen to run for governor after growing up in poverty in the rural Oregon town of Burns. This could only have enhanced her prestige among nonmetropolitan voters. These circumstances led the Oregonian (July $2,1986)$ to report that "there were good reasons to believe that voters living outside metropolitan Portland would not easily relate to Goldschmidt." Yet by the same account, Goldschmidt could prevail in the gubernatorial contest only if he could win a sizable share of the non metropolitan vote. 
Goldschmidt signalled his intention to contest the rural vote even before he initially announced his candidacy. Recall his "testing the waters" tour that brought him to Coos Bay. Speaking there, he called Portland "the head living off the body of the rest of the state" (Oregonian May 29, 1985): Clearly, Goldschmidt was seeking to distance himself from the propensity most voters had to identify him with Portland and in the process, curry favor with non metropolitan voters. Portland was Goldschmidt's political base so his remarks in Coos Bay must be considered implausible. More instructive was Goldschmidt's promise to lead an "Oregon Comeback," which would extend economic recovery to "those counties and constituencies that are most in need of a revived economy" (Oregonian November 7, 1986). He proposed to effect his "Comeback" by asking each area o the state to prepare "short lists" which could be placed on a "statewide economic development agenda" allowing Oregon's governor to concertedly focus state economic development activities upon prioritized economic development goals (Oregonian May $29,1985)$.

As expected, Neil Goldschmidt did very well among Portland's voters in Oregon's 1986 gubernatorial election. A high turnout gave him a 32,000 vote victory margin among Multnomah County voters. It's true he won only two of the seventeen largely rural Oregon counties east of the Cascade mountains. But if the state's six most heavily urbanized counties are excluded from the statewide tally, Goldschmidt still won over 52 percent of the popular vote (Oregonian November 7, 1986). Commenting upon the Goldschmidt campaign's performance, Jeff Mapes (October 31, 1989), political reporter for the Oregonian credited Goldschmidt's ability to "hold his own in most of the rural counties" to his promise to reshape state economic development policy in leading the "Oregon Comeback." 


\section{Securing Union Support}

The Goldschmidt campaign also made a concerted effort to recruit the union vote. Oregon's labor unions have traditionally supported Democratic candidates in gubernatorial elections. Yet there were reasons to question how strongly the unions would support Goldschmidt. According to Bob Baugh, former Oregon AFL-CIO Secretary-Treasurer and a principal architect of the AFL-CIO's 1982 "Reclaiming" report, (October 23, 1989), Goldschmidt's campaign opponent Norma Paulus had a good record on labor issues while serving as Oregon's Secretary of State. Union voters were also wary about the strong support Goldschmidt received from environmentalists. Many wood products workers viewed environmentalism as a threat to their livelihood. And union voters in the wood products sector could be expected to view Goldschmidt with the type of skepticism traditionally accorded Portland area candidates by residents of small cities and rural areas.

The Goldschmidt campaign sought to dispel concerns over its links to Oregon's environmental movement as early as July, 1985. While citing his record as evidence of his commitment to environmental protection, he argued nonetheless that in managing the state's natural resources, Oregonians should "do anything we can so they provide work for our citizens" (Oregonian July 3, 1985:D1). According to former Oregon AFL-CIO leader Bob Baugh (October 23, 1989), Goldschmidt promised the union leaders that if elected, he would afford the unions a consultatory role in shaping his economic development policy. Above all, however, Goldschmidt based his appeal to the unions upon a promise to create jobs. He conveyed this promise to the annual 1986 conference of the Oregon AFL- CIO, he said that "the state could no longer be divided into a number of regions, those that work and those that did not," adding that "the state has an investment every place" (Oregonian August 22, 
1985:B2). He reiterated his plan to refashion state economic development policy around a "state economic agenda," which would direct state resources to where they were most needed and could be best employed. Oregon's labor movement responded enthusiastically to the Goldschmidt campaign. Covering the 1985 AFL-CIO conference, the Oregonian (August 22, 1985) reported "there was little doubt it was love at first sight between Goldschmidt and the labor leaders." In fact, Goldschmidt received the endorsement of all but one of Oregon's labor unions in his race for the Governor's office (Oregonian October 27, 1987). The sole dissident union was that of the nurses, which endorsed Paulus.

\section{Building Bonds With Business}

As a candidate for the governor's office, Neil Goldschmidt made a concerted effort to elicit business community support. Speaking before Portland's City Club one month before Oregon's 1986 general election, he contrasted his career to that of his opponent for the governor's office, Norma Paulus. Only "one candidate in this race has actually worked in business, has earned a profit and lost money, and I've done both" said Goldschmidt as he contrasted his own career to that of Paulus, whose adult working life had been spent entirely in the public sector (Oregonian October 27, 1987). Addressing the 1987 conference of the Association of Oregon Industries, Oregon's main business lobby, Goldschmidt reminded his audience that as mayor, he had worked closely with Portland's business community to revitalize the city's downtown. Above all, he cast his appeal for business support in terms of his promise to refashion state economic development policy. Referring to his plan to establish a statewide economic development agenda, Goldschmidt promised Oregon's business leadership that if elected, he would establish a "business plan for the state" (Oregonian October 4,1986 ) which would make multiple state agencies work together with 
private business. According to Goldschmidt campaign materials, his administration would result in "an unprecedented level of private investment" (Goldschmidt Campaign nd).

The Goldschmidt campaign appears to have enjoyed success in recruiting business sector support. The Oregonian noted as much in an edition published the day after Oregon's November, 1986 gubernatorial election. The Oregonian (November 5, 1986:A1) reported that gubernatorial candidate Neil Goldschmidt "broadened his appeal to include prominent business people, who have traditionally backed Republicans."

\section{Submerging Differences}

When interviewed, Goldschmidt campaign aid David Bragdon (October 31, 1989) told the writer that "people got very nervous when ever Neil spoke about it." Asked to elaborate about what he meant by "it," Bragdon responded that he was referring to Goldschmidt's economic development platform. By people, Bragdon referred to Goldschmidt's campaign staff. According to Bragdon, the Goldschmidt campaign recognized the appeal its plan to reshape state economic development policy would hold to various constituencies, including Oregon's labor unions, rural voters and business leadership, and deliberately sought to promote its reform plan as a means of recruiting their electoral support. At the same time, the Goldschmidt campaign recognized that the state economic development question raised distributional issues around which these constituencies might diverge. The Goldschmidt campaign sought to avoid this prospect by deliberately submerging is economic development plan in unifying rhetoric. 
Despite the ambiguity that surrounded the Goldschmidt campaign's public pronouncements on state economic development reform, the campaign did have a palpable reform agenda. Goldschmidt's campaign statements hinted at the plan's three key features (Bragdon October 31, 1989; Baugh October 23, 1989, March 5, 1990; Webber November 18, 1989). First, local governments in each region would be encouraged to join together in promoting growth in a single targeted industry. Next, Oregon state government would conclude "memorandums of understanding with local governments' which stipulated specific actions the state would take to support local industrial promotion activities. And Oregon state government would be reorganized, increasing the governor's power over the state's fragmented bureaucracy and allowing the governor to concertedly direct the state's economic development resources to where they might most effectively contribute to local economic development efforts. More will be said of this scheme in the following chapter. At this point, its is more important to note the following.

First, the Goldschmidt campaign's plan for state economic development reform aimed at concertedly directing state resource allocations towards fueling growth in a-priori selected industries. Seen in this light, the Goldschmidt campaign's plan for reshaping economic development policy in Oregon appears as an incipient blueprint for statewide industrial policy. Second, recall that the City Club's 1983 proposal for reforming state economic development policy had called for industrial targeting. Also recall that the Oregon AFL-CIO's 1982 "Reclaiming" report called for a statewide economic development plan that would systematically coordinate and concentrate state economic development activities. In short, the Goldschmidt campaign's scheme to reform state economic development policy along industrial policy lines embodied tenets articulated by private non-state groups well before he entered the race to succeed Governor Atiyeh as Oregon's chief executive. 
The Goldschmidt campaign's coalition building strategy appears to have paid dividends. Goldschmidt won the overwhelming support of Oregon's labor movement. He also benefited from unusually strong business sector support. Oregon's labor and business leaders recognized Goldschmidt's coalition building effort for what it was. For example, commenting on Goldschmidt's 1986 gubernatorial campaign, former Oregon AFL-CIO Secretary-Treasurer Bob Baugh (March 5, 1990) told the writer that "nobody else had tried to bring us together before." Baugh was asked what he meant. By "us," Baugh meant Oregon's labor unions and business leadership. Business leaders David Bolander (November 22, 1989:), former President of Pacific Power and Light Company and Richard Reiten (February 27, 1990) former President of Portland General Electric Company, expressed similar sentiments when interviewed.

Still, that the Goldschmidt campaign's promise of economic development reform found favor with leaders of Oregon's labor movement and business community should not be interpreted to mean that they shared consensus on economic development policy goals, for this was not the case. To take the an obvious example, in 1986, amidst Goldschmidt's campaign for governor, power company executive David Bolander called for Oregon to improve its business climate by rolling back state workers compensation benefits, amongst the highest in the nation (Oregonian June 20, 1986). This was a proposal to which the AFL-CIO's Bob Baugh was unalterably opposed. Oregon's labor and business leaders agreed to endorse the Goldschmidt campaign's economic development platform not because their economic development goals coincided but because each had an interest in economic development and each saw Goldschmidt's plans for reforming state economic development policy along industrial policy lines as a vehicle for attaining these aims. 
Mandate for Industrial Policy Reform

Oregon's 1986 gubernatorial election offered voters a choice. Neil Goldschmidt promised to reform state economic development policy so as to transform the state into an active agent of economic restructuring. His opponent, Norma Paulus was seen as offering voters little in the way of reform. For example, debating Goldschmidt before a City Club audience in October, 1986, one month before election day, Paulus:

told the group that state government had ignored the business Community in developing strategy, and that as a result, Oregon lags behind the state of Washington, which...has allowed the business sector to dictate economic policies of Washington (Oregonian October 4, 1986).

Paulus charged that "in the past, the state legislature has antagonized rather than aided business." She also said that if elected governor, she would "insist" that the state's business community be allowed to set economic policy priorities. Exactly what this would have meant in practice remains unclear to the writer. But as the Oregonian reported, there was little in Paulus remarks to indicate that she envisaged breaking significantly from the economic development program of the Atiyeh Administration, a point Goldschmidt drove home in his comments before the City Club audience.

The Goldschmidt campaign prevailed in Oregon's 1986 gubernatorial election, capturing 53 percent of votes cast. Goldschmidt won the governor's office by what the November 7, 1986 edition of the Oregonian described as a "respectable margin." His victory was widely interpreted as providing him a mandate to reform state economic development policy. Goldschmidt wasted little time in moving to put his mandate into practice. The same edition of the Oregonian reported that his transition team would immediately "start developing the regional economic agendas that Goldschmidt made a central theme of his campaign." 


\section{SUMMARY}

Democratic gubernatorial candidate Neil Goldschmidt embraced key industrial policy principles originally articulated by private labor and business groups as a vehicle for promoting economic restructuring but more immediately, as a vehicle for fashioning an electoral coalition between groups which, divided by other differences, nonetheless shared a common interest in state economic development policy reform. Successful in his bid for the Governor's office, Goldschmidt emerged from Oregon's 1986 gubernatorial election with a mandate to reform state economic development policy along industrial policy lines. 


\section{NOTES}

1. Prior to facing off with Paulas, Goldschmidt defeated State Senator Ed Fadeley in Oregon's May, 1986 Democratic party primary election, capturing 70 percent of votes cast (Secretary of State nd).

2. Neil Goldschmidt was not interviewed during the course of this research. Despite attempts to do so, the writer was unable to arrange an interview. However, Roger Smith (December 8, 1989), chief of Goldschmidt campaign fund raising, was interviewed. So was Bill Scott (November 7, 1989), manager of Goldschmidt's gubernatorial campaign. Scott was a longtime Goldschmidt confident; earlier he had served Goldschmidt as an aide during his tenure as mayor of Portland. Also interviewed were David Bragdon (October 31, 1989) and Mike Wetter (November 2, 1989), key staffers on the Goldschmidt campaign's issues team. Unless cited otherwise, the discussion in this chapter is based upon interviews conducted with these Goldschmidt campaign officials.

3. Goldschmidt's roots in Oregon ran deep. He had studied political science at the University of Oregon after growing up in Eugene, the state's second largest city. He earned a law degree at UC Berkeley before returning to Portland to become first a legal aid-attorney, then a city commissioner (1970-71) and next, the city's mayor (1972-79). In 1979, President Jimmy Carter made Goldschmidt U.S. Secretary of Transportation. With Ronald Reagan's election as President, Goldschmidt became an executive at Nike Inc., the sports apparel maker. In 1985, Goldschmidt announced his resignation from Nike to enter the race to succeed Governor Atiyeh as Oregon's chief executive. 


\section{CHAPTER V}

\section{THE POLITICS OF INDUSTRIAL POLICY ADOPTION}

The Goldschmidt Administration's plan for reforming state economic development policy along industrial policy lines aimed to promote growth in emerging industries, objectify policy choice, centralize economic development administration, and perpetuate the Administration's tenure in office, features indicative of state autonomy. Its mandate to reform state economic development policy not withstanding, however, the Administration had to secure legislative authority to put its industrial policy scheme into practice. Lawmakers attached several conditions to their

authorization. These conditions point to limitations that tensions founded regionalism, localism, and rivalries between the branches of Oregon state government placed upon the Goldschmidt Administration's prospects for autonomous action.

\section{REGIONAL STRATEGIES AS INDUSTRIAL POLICY}

Aides to Governor-elect Neil Goldschmidt began drafting the Regional Economic Development Act shortly after Oregon's November 1986 election. The Act created the Regional Strategies program, the centerpiece of the Goldschmidt Administration's industrial policy scheme. The Act was introduced in the Joint Committee on Trade and Economic Development (T\&E) of the Oregon state legislature as HB 3011 on February 20, 1987 and passed out of T\&E on April 24, 1987. It was adopted by both houses of the Oregon legislature shortly thereafter. Governor Goldschmidt signed the Act into law on, May 11, 1987.1 
Through the Regional Strategies program, the Goldschmidt Administration aimed to provide a public good--economic development--which private market forces were unlikely to provide of their own accord. Section 3 (2)(b) of HB 3011 helps make this point. It reads: "the Legislative Assembly finds that regional strategies are key to the state's economic revitalization."

Section 4 (1) of HB 3011 provided that "not later than 60 days after the effective date of this Act, by rule, the department shall adopt standards for regional economic development strategies." Drawing upon the provisions of HB 3011 and the standards developed by EDD, the principal features of the process by which the Regional Strategies program was to be enacted can be identified. These features point to an economic development policy arrangement focused upon promoting growth in emerging industries, stressing the objectification of policy choice, and consolidating and centralizing administration of economic development planning, features indicative of state autonomy.

Regional Strategies aimed to focus state and local economic development activities upon "economically viable industries, with reasonable long term growth prospects, including...innovative new industries" (HB 3011 Section 4 [2][a]). Commensurate with this goal, each of Oregon's thirty-six counties was to select a "principal industry or economic activity" which would serve as the focus of state supported activities to promote local economic development (HB 3011 Section 5 [1]). Program guidelines promulgated by EDD defined a principal industry as:

A basic industry such as tourism/recreation, secondary wood products manufacturing, manufacturing of special types of goods, high technology, agriculture, or food processing; or a focused economic activity, such as research and development or international trade, which has a demonstrated potential to create jobs in a particular industry (EDD nd a). 
Each county was to base selection of its target industry or economic activity upon an analyses of the local economy, the purpose of which was to:

identify and analyze the specific [local] economic opportunities and liabilities, to identify and analyze unique resources in the region that might be marshaled [sic] in support of a regional strategy [for promoting local economic development], and to evaluate strategy ideas (EDD nd a).

Criteria were provided to guide counties in principal industry selection. The most important provision required that selection of a county's principal industry be guided by its potential for creating "family wage jobs." The potential for creating "family wage jobs" was the main performance standard upon which Regional Strategy selections were to be based. Guidelines established by EDD lent fairly precise definition to exactly what counted as a family wage job. The economic development agency's guidelines defined a family wage job as "a full time equivalent job with a wage greater than 80 percent of the median income for a family of two in the county where the majority of employees reside" (EDD nd a).

The Regional Strategies arrangement was clearly intended as a vehicle for consolidating and centralizing the administration of economic development planning in Oregon. Section 3 (10 of HB 3011 helps make this point. It read, in part: "to be effective, regional strategies must have the coordinated support of all available resources." In turn, the provisions aimed at coordinating economic development activities can be seen as having been directed at increasing Oregon's administrative capacity for economic development.

There were several dimensions to the Regional Strategies capacity building scheme. First, the Regional Strategies arrangement aimed to consolidate and coordinate economic development planning activities at the local level. Referring to an arrangement by which two or more counties would join together in a compact to target a single principal industry or economic activity for promotion, Section 6 of $\mathrm{HB}$ 
3011 provided that "Wherever possible, the governing bodies of counties shall work to form multi-county regional strategies." HB 3011 did not prohibit counties from unilateral implementation of Regional Strategies unilaterally. The clear intent of $\mathrm{HB}$ 3011 was to discourage counties from doing so, however.

Next, the Regional Strategies arrangement aimed to systematically channel local demands for economic development assistance to state government. Section 5 of 3011 provided that "each county or group of counties that form a region submit a regional strategy," including a statement identifying its chosen principal industry or economic activity and the economic analysis upon which the decision to select the industry was based. Also to be included in Strategy submissions was a project list. Section 5 of HB 3011 established the project lists "as a basis for state financial assistance to projects to aid a regional economy." The lists were to be comprised of "a spirited [sic] list of activities to be undertaken or funded by the state from lottery proceeds and other sources." Included under other sources were "funds from...state agencies, such as the Oregon Department of Transportation or the State Marine Board" (EDD nd a). Also included as sources were local governments and the federal government. Section 4 of HB 3011 provided that "public investments [be] matched, to the maximum extent possible, by the contributions of private financial and other resources."

Under the terms of HB 3011, the governing board of each county party to a Regional Strategy was required to hold two public hearings. The first was to be held prior to selection of a principal industry or economic activity, the second, prior to any vote on formal strategy adoption. Counties were required to provide two weeks notice prior of the hearings. 
Upon formal adoption of a Regional Strategy, it was to be forwarded to officials at the Oregon Economic Development Department. Section 5 of HB 3011 made EDD responsible for overseeing administration of the Regional Strategies program. The Department's responsibilities included providing technical assistance to local authorities seeking to analyze their economies, select target industries and put together project lists. Also, EDD was directed to review Strategy submissions to ensure compliance with the program's founding statutes and administrative rules. Section 7 of HB 3011 provided EDD with another important responsibility as well. This was to "coordinate adopted Regional Strategies with existing state and local economic development efforts." This points to the third element in the Regional Strategies arrangement aimed at building Oregon's capacity for economic development planning by consolidating and centralizing economic development functions: EDD was to serve as a vehicle for coordinating the concerted response of state agencies to the requests contained in strategy project lists. The Economic Development Department's role in overseeing implementation of Strategies will be discussed at length later in this chapter. Further comment on how EDD was supposed to coordinate the economic development of state agencies is deferred until then.

Last, Section 7 of HB 3011 reserved for Oregon's governor sole discretion for approving or rejecting, and therefore providing funding for, submitted Strategies. Oregon's governor had the final word in deciding what industries were targeted for promotion, what Strategy projects would be funded and hence, by what measures industrial promotion would be effected. This provision had the effect of centralizing ultimate responsibility for the decisions that defined the Regional Strategies program in the office of Oregon's governor. If the Governor chose to accept a county's Strategy, HB 3011 directed that he sign an agreement with the county's governing 
board. This agreement committed each of the two parties--the county and the governor--to fulfill obligations delimited under the terms of the pertinent project list.

\section{POLITICAL OPPORTUNITIES IN REGIONAL STRATEGIES}

The Regional Economic Development Act was intended not only as a vehicle for promoting economic restructuring but as a vehicle for pursuing another aim as well. It was designed as an instrument for perpetuating the Goldschmidt Administration's tenure in office. This point was first raised in an interview I conducted with Alan Webber, (November 11, 1989), a longtime Goldschmidt confident. Webber advised Goldschmidt in the formulation of the Regional Strategies arrangement.

According to Webber, the arrangements set forth in HB 3011 were largely modeled upon a neighborhood planning system that Goldschmidt had established while serving as Portland's mayor during the 1970s. Under the Portland system, neighborhood planning organizations channeled "neighborhood needs reports," annual lists of prioritized demands for municipal services, to city hall. The analogy between the neighborhood system and Regional Strategies becomes clear if Oregon's counties are substituted for Portland's neighborhoods and the Strategy project lists for the neighborhood needs reports.

That Regional Strategies was diffused from Goldschmidt's experience in Portland is perhaps unsurprising. As Abbott (1983) notes, Goldschmidt was elected mayor at a time when Portland's municipal government confronted a crisis of public authority not dissimilar in many ways to that faced by Salem in the mid-1980s. More telling, however, is the fact that upon adopting Goldschmidt's neighborhood planning proposal, the Portland city council did not permit Mayor Goldschmidt to oversee the 
program's implementation himself. According to Abbott, they feared Goldschmidt would use the program to build a personal political organization. As with the Portland neighborhood program, the policy arrangement cast by HB 3011 offered opportunities for the building of such an organization since under Regional Strategies, Governor Goldschmidt would enjoy great discretion in disbursing state lottery dollars. He would thus be well positioned to reward those interests which provided support for his own future political ambitions.

Clearly, Governor Goldschmidt did not lack for political ambition. He was successfully elected mayor of a major American city at the relatively young age of 32 . Without assurance of victory in his quest for the governor's office, he had quit a high paying job as a Nike executive. As to exactly what his future political aspirations might have been, this is unclear. At the least, he probably aspired to a second term as governor. Commentators have long speculated upon the vulnerability of either of Oregon's two veteran Republican senators to a Democratic challenger capable of generating widespread support statewide. Since Oregon's governor was constitutionally limited to two terms, Goldschmidt may also have hoped to ultimately succeed one of the two.

The potential for the Goldschmidt Administration to have used Regional Strategies to build political support was recognized in the Oregonian. In its June 28, 1987 edition, published about a month after HB 3011 was signed into law, the newspaper reported that Regional Strategies gave Governor Goldschmidt "a mandate to organize in areas of the state where Republican Norma Paulus out polled him in November." In light of this, it can be concluded that the Regional Strategies the Regional Strategies arrangement embodied, in addition to economic development, 
another goal indicative of state autonomy as well, this being the perpetuation of the Goldschmidt Administration's tenure in public office.

\section{LEGISLATIVE CONSTRAINTS UPON AUTONOMY}

The Goldschmidt campaign's 1986 election victory was widely seen as a mandate on the economic development policy question which, by 1987 , had dominated public policy debate in Oregon for over six years. This could only have placed great pressure upon lawmakers to approve Goldschmidt's plan to reform state economic development policy along industrial policy lines. Still, many lawmakers viewed state economic development policy reform with skepticism. This became clear the first time Goldschmidt Administration officials met to discuss Regional Strategies with lawmakers from the legislature's T\&E Committee. The Oregonian (January 29, 1987) sought to capture the tone of the meeting under the headline "Governor's Economic Planners Grilled."

The Goldschmidt Administration succeeded in securing legislative endorsement of Regional Strategies. The legislature's endorsement of the Administration's plan was not unqualified, however. Instead, lawmakers attached several conditions to their Regional Strategies authorization. These conditions point to limits upon the prospects that the policy arrangements provided for in HB 3011 would lead to an expansion in Oregon's capacity for economic development and the Goldschmidt Administration's prospects for to independently pursue its goals. ${ }^{2}$

\section{Gambling With Economic Development}

Funding for the Regional Strategies program was to be provided under the terms of SB 964. The omnibus appropriations bill reserved $\$ 25$ million in state lottery money for the use in funding projects submitted as part of local strategy project lists. 
Oregon's voters had established the lottery through the initiative process in November, 1984 , dedicating lottery proceeds to economic development.

The first half of the 1980 s was a period of austerity for Oregon. With budgets for established programs being cut back, little money was available to launch new initiatives. The lottery changed this.. It created a large pool of money which, as long as it was spent for economic development, had few strings attached. The lottery greatly expanded the economic development policy making capacity of Oregon state government, making the Regional Strategies program possible. It merits noting, however, that the boost that the lottery provided to Oregon's policymaking capacity was tenuous. Lawmakers inserted a proviso into SB 964 that made distribution of lottery money appropriated for the Regional Strategies program contingent upon its availability. There was a precedent for this. Officials had estimated that the year beginning July 1,1985 , would generate some $\$ 121$ million in lottery proceeds for state economic development programs. But sales of lottery tickets had fallen short, forcing officials to lower this estimate by 20 percent, to $\$ 98$ million (Oregonian January 31 , 1986). As it happened, lottery sales subsequently increased and Regional Strategies was never faced with a shortfall in its appropriated $\$ 25$ million. The proviso was thus rendered moot. Still, these circumstances highlight an important issue. While the availability of lottery money increased Oregon's economic development policy making capacity, the boost in capacity was not certain. It depended upon the vicissitudes of lottery gaming. In effect, Oregon was gambling with its capacity for economic development. 


\section{Division of Powers}

The Goldschmidt Administration's plan for reshaping state economic development policy called for concentrating a great deal of power in the hands of Oregon's governor. The Administration sought sole authority for dispensing $\$ 25$ million in lottery money. The Administration also sought to extend the control Oregon's governor could assert over Oregon's fragmented state bureaucracy. Goldschmidt's electoral mandate made it difficult for lawmakers to deny him the authority he sought. Still, lawmakers were careful to minimize the prospects that an expansion in the Goldschmidt Administration's authority would result in a commensurate reduction in their own authority. They inserted a Sunset Clause into HB 3011, which limited the Regional Strategies program to a single biennium only. Lawmakers also denied the Goldschmidt Administration control it was seeking over several of the quasiindependent policy making commissions that oversaw the operations of key components of Oregon's bureaucratic apparatus. Insertion of the Sunset Clause into HB 3011 and denial of authority over the commissions points to rivalries endemic to the division of powers between Oregon's branches of government as the source of limitations upon the likelihood that the Goldschmidt Administration would be able to secure key industrial policy goals.

Sunset Clause The Sunset Clause was inserted into HB 3011 (Section 8) at the insistence of lawmakers on the T\&E Committee. The Sunset Clause provided that authorization for Regional Strategies would expire on July 1, 1989. All strategies had to be complete and approved by the Governor at that time. The Sunset Clause limited Regional Strategies to one biennium only.

The Goldschmidt Administration opposed the Sunset Clause. According to Goldschmidt aides involved in drafting HB 3011, Governor Goldschmidt believed it 
would take more than a single two-year biennium of strategy development to promote economic restructuring and renewal in Oregon's lesser developed regions (Bragdon

October 31, 1989; Wetter November 2, 1989; Lohman November 21, 1989). It was on these grounds that EDD's David Lohman argued against insertion of the Sunset Clause before the T\&E Committee. Lohman told T\&E lawmakers that:

The whole idea behind the regional strategies is to allow the regions to develop an economic strategy that's going to be significant enough--that it's going to be self-sustaining--that it's going to be a major hit. If we are going to look at funding only in this biennium, then I think we're looking at a much smaller effort in terms of the regional strategies (Joint Legislative Committee on Trade and Economic Development February 23, 1987).

The argument that a single biennium would be insufficient to effectively promote economic restructuring in Oregon's less developed regions appears a credible enough reason for the Goldschmidt Administration to have opposed the Sunset Clause. The Administration's plan to use the Regional Strategies program as a vehicle for recruiting political support in a reelection bid suggests another reason as well. Installed in office for a four year term, the Administration was likely to be campaigning for reelection not during the 1987-88 biennium but during the 1989-91 biennium. If the Administration's ability to dispense lottery money was to serve as a vehicle for recruiting electoral support, it was likely to most effectively do so during the two year period coinciding with the 1989-91 biennium. In other words, the Sunset Clause would have precluded the Administration from dispensing lottery money during the period in which doing so was most likely to serve the Administration's political agenda.

The Goldschmidt Administration had good reason to view the Sunset Clause as a potential impediment to its ability to pursue two key goals--economic restructuring and political perpetuation. The Administration's protestations not 
withstanding, lawmakers were adamant that the Sunset Clause be included in HB

3011. Trade and Economic development Committee Chairman Wayne Fawbush made this clear in remarks directed to Roger Smith, Lohman's chief:

So, while as far as you're concerned this is a permanent part of the Goldschmidt administration, we're approaching it from the point of that its a two year program. Period [sic] (Joint Legislative Committee on Trade and Economic Development February 20, 1987).

Legislative insistence upon the Sunset Clause appears to have been driven by three concerns. First, according to Senator Fawbush, the T\&E Committee insisted upon inserting the Sunset Clause into HB 3011 because it did not want to provide ongoing authorization for a program the need for which might no longer exist in two years (Joint Legislative Committee on Trade and Economic Development February 20, 1987).

The second reason why legislators insisted upon inserting the Sunset Clause into HB 3011 was insinuated in the June 28, 1987 edition of the Oregon. According to the newspaper, prior to the advent of Regional Strategies, local communities seeking state assistance for economic development projects had to depend upon the "largess of the Joint Trade and Economic Development Committee and the Joint Ways and Means Committee. Sometimes, the results looked like pork barrel politics." With Regional Strategies, reported the Oregonian, "the governor holds the barrel." I cited this article in asking two key lawmakers about the Sunset Clause. The lawmakers were Larry Campbell (November 4, 1989), Republican minority leader in Oregon's House of Representatives and a T\&E Committee member during the legislature's 1987 session and Vera Katz, Speaker of the Oregon House of Representatives during the same period (November 2,1989). Their answers led me to conclude that legislators insisted upon inserting the Sunset Clause into HB 3011 not only because they wanted to avoid providing ongoing authorization to a program a future need for 
which might not exist but also because they did not want to establish a precedent for future erosions of the control they themselves exercised over lottery spending. Limiting the authorization for Regional Strategies to one biennium only meant that authority for spending lottery money would revert back to the legislature after the conclusion of the 1987-88 biennium.

Partisan politics also appears to explain why lawmakers insisted upon inserting the Sunset Clause into HB 3011. This became clear in the interview I conducted with Representative Campbell. Campbell was leader of the minority party Republicans in Oregon's House of Representatives during the legislature's 1987 session. He was, by reputation, one of the legislature's most highly partisan politicians. Campbell said the Sunset Clause reflected the apprehension he and his fellow Republican lawmakers felt over granting the Goldschmidt Administration discretionary authority over $\$ 25$ million in lottery money. Campbell and his Republican colleagues realized that the Regional Strategies program provided the Goldschmidt Administration a "mandate to organize in areas of the state where Republican Norma Paulus out polled him in November" (Oregonian June 28, 1987). The legislature's Republicans had no desire to assist Goldschmidt in this matter. They insisted on inserting the Sunset Clause into HB 3011 because they believed that by limiting Regional Strategies to one biennium only, they prohibited the Administration from dispensing lottery money during the period in which it would be gearing up for reelection and thus undermined the Administration's ability to use Regional Strategies to expand its political base.

The Sunset Clause limited authorization for Regional Strategies to one biennium only. In doing so, it placed a constraint upon the Goldschmidt Administration's ability to pursue its goals, forcing the Administration to stress 
expediency in local strategy implementation so as to set the stage for reauthorizing Regional Strategies, as will become clear in later chapters. Insertion of the Sunset Clause into HB 3011 had little to do with objective calculations of how Oregon's resources might best be tapped to promote economic restructuring. To the contrary, there would appear to be merit in the Administration's argument before the T\&E Committee that economic restructuring would take several iterations of Regional Strategies intervention and therefore, that the Sunset Clause could comprise an obstacle to an effective restructuring effort. Whatever the merits of this argument, it was subordinated to the reluctance of lawmakers to cede the Administration too much authority at their own expense and to political rivalries. Politics, not objective calculations of how best to promote economic restructuring led to the insertion of the Sunset Clause into HB 3011.

Barriers to Centralization The commissions that presided over key Oregon state government agencies infused Oregon state government with a high degree of fragmentation. Furthermore, because the commissions were composed of political appointees serving fixed terms, an incoming administration would always find itself dealing not with commissions composed of its own appointees but with the appointees of a preceding administration. This was the situation the Goldschmidt Administration inherited when it came into office--having to deal with a fragmented commission structure composed of commissioners appointed during the preceding eight year tenure of the Atiyeh Administration.

The Goldschmidt Administration believed that a successful economic restructuring effort required that Oregon's capacity for economic development be increased by consolidating control over the state government bureaucracy. The Administration apparently saw the existence of diffuse commissions filled with 
appointees from a previous administration as an impediment to concerted economic development action and consequently, attempted to subordinate certain key commissions to the Governor's authority. Doing so could have maximized the likelihood that the agencies over which these commissions presided acted concertedly and with minimal deviation in pursuing the Administration's goals. The Administration's vehicle for boosting the Governor's control over key state agencies was an early draft of HB 3011, which contained the following three provisions:

The Economic Development Commission shall provide expedited consideration of requests for loans if the Governor finds that the business activity to be financed is essential to the implementation of an adopted regional economic development strategy (Section 6).

The Environmental Quality Commission shall give priority in the distribution of funds available through the federal Clean Water Act to projects that are designated by the Governor as essential for the implementation of an adopted regional economic development strategy (Section 9).

The Oregon Transportation Commission shall give priority to projects designated by the governor as essential for the implementation of an adopted regional economic development strategy (Section 10).

The clear aim of these provisions was to boost the governor's power over Oregon's fragmented state government apparatus. However, none of these three provisions were included in the enrolled final version of HB 3011 that authorized Regional Strategies. All three were deleted from HB 3011 at the insistence of lawmakers on the T\&E Committee (Joint Committee on Trade and Economic Development February, 28, 1987). According to Representative Campbell (November 4, 1989) of the T\&E Committee, these provisions were rejected on the grounds that they would have concentrated too much power in the hands of Oregon's governor. In vetoing these provisions, lawmakers denied Goldschmidt authority he sought to enhance Oregon's capacity for economic development planning. Commensurately, they also denied him authority he sought to expand the autonomy of the governor's office. 
The apparent upshot of the rejection of the Goldschmidt Administration's efforts to subordinate the state Economic Development, Environmental Quality and Transportation Commissions to the Governor's office was to make the state Economic Development Department responsible for coordinating the provision of assistance sought from state agencies under the aegis of Strategy project lists. Clearly, this arrangement offered the Administration less robust control over the state's bureaucratic apparatus than it would have preferred. For whereas the Administration's initial plans had called for the direct subordination of key policy making bodies to its authority, under the terms of HB 3011, EDD was endowed only with responsibility for coordinating "adopted Regional Ștrategies with existing state and local economic development efforts" (HB 3011 Section 7). The economic development department was given no explicit authority, coercive or otherwise, with which to ensure this coordination. Furthermore, no mechanism was provided to ensure that the commissioners that retained quasi-autonomous authority over the Economic Development as well as the Environmental Quality and Transportation Departments and other state agencies did not embrace goals and promulgate directives inconsistent or even at odds with those of the Governor.

If the arrangement by which EDD was directed to oversee implementation of Regional Strategies offered the Administration less robust control over the state's bureaucratic apparatus than it would have preferred, it is clear nonetheless that the Administration aimed to employ this less robust arrangement to the maximum advantage possible. A look at the composition of EDD's Regional Strategies unit makes this point. The unit was created subsequent to authorization of Regional Strategies. It was made responsible for overseeing EDD's Regional Strategies responsibilities, including coordinating "adopted Regional Strategies with existing 
state and local economic development efforts" (HB 3011, Section 7). All three of the staffers hired by EDD to oversee Regional Strategies were former Goldschmidt campaign staffers (Wetter November 2, 1989; Sanderlin June 11, 1990; Delman January 29,1991$)$. This sort of patronage is not necessarily unusual. Still, the three campaign staffers could be assumed to have a high degree of personal loyalty to Governor Goldschmidt. That former campaign workers were placed in these positions is indicative of the high degree of control that Governor Goldschmidt aimed to assert over the Regional Strategies program.

\section{$\underline{\text { Regionalism }}$}

The so-called "no-seconds" clause was inserted into HB 3011 as Section 8 [2]. In statutory terms, the no-seconds clause prohibited any county from submitting a second strategy request for state assistance before every county in the state had its strategy approved by the Governor. As a practical matter, however, its insertion into HB 3011 was more pervasive. For what the no-seconds clause really did was to ensure that every area of Oregon received a share of the lottery money allocated to fund Regional Strategies and thus, to limit the degree of discretion the Goldschmidt Administration would be able to exercise in using the Regional Strategies arrangement to pursue its economic development goals.

As originally drafted, HB 3011 did not contain any "no-seconds" clause. It was inserted into HB 3011 as an amendment, mainly at the insistence of lawmakers from Oregon's rural areas and small cities. They feared that metropolitan counties, having greater administrative resources, would mobilize more quickly than their own districts and might come back for a second helping of lottery money before their own constituencies saw their first. Rural and small city lawmakers inserted the no-seconds clause to preclude this possibility. Still, rural and small city lawmakers had a deeper 
purpose in inserting the no-seconds clause. For at the same time they amended HB 3011 to include the no-seconds clause, they extracted from the Goldschmidt Administration a promise that every area of Oregon would receive a share of the lottery money.

The Goldschmidt Administration opposed the no seconds rule. Deputy Director Lohman of EDD explained to the T\&E Committee that Governor Goldschmidt wanted Regional Strategies to emphasized "quality, not speed" (Joint Legislative Committee on Trade and Economic Development, February 25, 1987). When interviewed, Lohman (November 21, 1989) elaborated. He said that Governor Goldschmidt wanted to competitively evaluate the different strategy proposals submitted to him, funding the most promising first and reserving action on less promising proposals, that needed more work, for the following biennium. He believed this was necessary in order to selectively concentrate the state's limited economic development resources in a mass critical enough to promote development. The Administration saw the no-seconds clause as likely to lead to the diffuse and hence ineffectual application of state economic development resources. The Administration may have had another reason to oppose the no-seconds clause as well. The Administration may have viewed no-seconds as an impediment to its ability to attain its political goals. For by requiring the Administration to allocate lottery money to all areas of the state, lawmakers limited the Administration's ability to use the Regional Strategies arrangement to favor supportive constituencies at the expense of less supportive constituencies.

Support for and opposition to the no-seconds clause broke down along regional lines. Whereas lawmakers from Oregon's.rural areas and small cities insisted upon it, their counterparts from the Portland metropolitan area allied themselves with 
the Goldschmidt Administration in opposing the clause. For example, State Senator Glenn Otto, who represented east Portland in the Oregon legislature and sat on the T\&E Committee called no-seconds "unfair" (Joint Legislative Committee on Trade and Economic Development February 25, 1987). But rural and small city lawmakers insisted upon insertion of the no-seconds clause into HB 3011 as the price of authorizing the program. They were well positioned to do so. For of the twelve legislators who sat on the committee during the 1987 legislative session, seven were from outside the Portland area. Ascendant on the T\&E Committee, lawmakers from Oregon's small cities and rural areas succeeded in making the no-seconds rule a part of HB 3011 .

As with the Sunset Clause, insertion of the Sunset Clause into HB 3011 had little to do with objective calculations of how Oregon's resources might best be tapped to promote economic restructuring. To the contrary, there would appear to be merit in the argument that economic restructuring could best be promoted by concentrating state resources where they could do most good, instead of diffusing their application. Whatever the merits of this argument, it was subordinated to regional rivalries. Political calculations, not objective calculations of how best to promote economic restructuring led to the insertion of the no-seconds clause into HB 3011.

\section{Localism}

Earlier it was argued that localism is a fundamental tenet of Oregon politics. Localism came into play amidst the legislature's deliberations over HB 3011 in terms of provisions relating to the establishment of multi-county regions and the decision to make Oregon's counties responsible for local implementation of Regional Strategies.

It's already been noted that Section 6 of HB 3011 provided that "wherever possible, the governing bodies of counties shall work to form multi-county regional 
strategies." Goldschmidt viewed the need for multi-county collaboration as a fundamental tenet of Regional Strategies. For their part, lawmakers appear to have been of two minds over this provision. Seemingly adhering to Goldschmidt's position, T\&E Committee Chairman Wayne Fawbush said that he would consider Regional Strategies a "failure" if it were not implemented through multi-county regions (Joint Legislative Committee on Trade and Economic Development February 27, 1987). Fawbush wanted language inserted into HB 3011 that would have had the governor designate regional groupings. Other lawmakers were concerned about the prospect that Goldschmidt might impose regional groupings of his own liking regardless of local preferences. Included was Yamhill County's Stan Bunn. This placed the Goldschmidt team in a seemingly equivocal position. Before the T\&E Committee, EDD's David Lohman testified that "the Governor would not be imposing his own ideas on what regions should be." (Joint Committee on Trade and Economic Development February 18, 1987). In the end, compromise language was worked out. Section 4 [3] of HB 3011 provided that EDD "expedite and facilitate the definition of regions, based on historical, cultural and economic links among counties by recommending groupings of counties to form regions." In any event, it's's important to note that nothing in HB 3011 prohibited individual counties from submitting Strategies unilaterally.

As will become clear in Chapter VII, there was something of a prescient quality in the concerns lawmakers expressed over multi-county implementation of Regional Strategies. Chapter VII will depict the Goldschmidt Administration acting forcefully to forge a multi-county strategy compact in Southern Oregon, overriding local preferences in the process. It will be argued that the forcefulness of the Administration's action was driven, in part at least, by fear that a failure to deliver on 
multi-county implementation of Regional Strategies would color the program as, to quote Senator Fawbush, a "failure," threatening the Administration's goal of seeing the Regional Strategies program reauthorized. By the same measure, Chapter VII will show local officials citing Lohman's promise to Senator Bunn that the Governor would refrain from imposing his idea of what regions should be when protesting the Administration's region building maneuvers.

Finally, according to Gordon Fultz (November 21, 1989), Executive Director of the Association of Oregon Counties (AOC), Oregon's counties were ambivalent over the role HB 3011 provided for them. They looked forward to the prospect of lottery funding for economic development projects. But they were reluctant to assume responsibility for conducting economic analysis and preparing and submitting Strategy projects lists.

At the time Goldschmidt was formulating his Regional Strategies arrangement, county governments in Oregon had little experience in the economic development domain. This was documented in a report published in 1989 by Oregon's Bureau of Governmental Research and Service (BGRS), a research institute affiliated with the University of Oregon. According to BGRS, in 1986 "There [did] not appear to be any clearly identified economic development personnel in county government" (Bureau of Government Research and Service 1989). This could only have cast doubt upon the administrative capacity of county governments to effect provisions of HB 3011, especially technical tasks such as analyzing the local economy. Furthermore, the years leading up to 1987 were, for many of Oregon's counties, a period of fiscal scarcity. Meeting established responsibilities strained their available resources. The counties did not look forward to being saddled with additional responsibilities with which they were unaccustomed. This was especially 
true in light of the fact that HB 3011 made no provision for using lottery money to enable counties to meet the administrative responsibilities accorded them under $\mathrm{HB}$ 3011. Lottery money could be used only to fund Strategy projects.

It is instructive to note here that the question of allocating lottery money to provide counties with the resources necessary for meeting their Regional Strategies responsibilities was raised with Goldschmidt by Dr. Larry Blake, President of the Oregon Institute of Technology. Formerly, he had been a community college President in North Carolina where he had worked on economic development issues. During his campaign, Goldschmidt invited Blake to meet with him to discuss economic development policy. Blake recommended that lottery money be made available to improve local economic development policy capacity. Little appears to have come of this recommendation, however, for reasons which remain undetermined.

Given the above circumstances, the Association of Oregon counties gave HB 3011 only tepid support. In light of this, it as instructive to examine how the decision to implement HB 3011 through the counties came about. This issue was addressed in interviews conducted with Goldschmidt aides and advisers David Bragdon (October 31, 1989), Mike Wetter (November 2, 1989) and Alan Webber (November 11, 1989). According to the above cited 1989 report by the Bureau of Governmental Research and Service, Oregon's municipal governments had widespread economic development responsibilities in 1986. Yet, it seems that the Goldschmidt team never seriously considered implementing Regional Strategies through city government. The reason was two-fold. First, much of Oregon's population lives in unincorporated areas. This is especially true of many rural, timber dependent areas. It was towards fostering economic renewal in these areas that Regional Strategies was primarily aimed. A municipal implementation scheme would have excluded these areas. Also, 
the Goldschmidt team appears to have viewed cities as too fractious a level for building the consensus over a restructuring strategy that Goldschmidt saw as necessary. This latter factor ruled out implementing Regional Strategies under an arrangement resembling that provided for under Oregon's system of land use planning, for example, in which implementation responsibilities are shared between cities and counties.

The question of implementing Regional Strategies through Oregon's Councils of Government (COGs) arose in deliberations over HB 3011 by the Legislatures T\&E Committee. The COGs are multi-county entities. And according to the above cited report by the Bureau of Governmental Research and Service, in 1986, most of Oregon's COGs had well established economic development responsibilities. At least on the surface, these circumstances would appear to have made COGs well suited to implementing an economic development program aimed at encouraging extra-territorial collaboration, as did Regional Strategies. But Senator Joyce Cohen of the T\&E Committee said that she would "resist the COG suggestion because of misgivings about COGs." Her colleague on T\&E, Representative Wayne Fawbush called some COGs "atrocious" (Joint Legislative Committee on Trade and Economic Development February 27, 1987). Fawbush and Cohen served as co-heads of the T\&E Committee. Given the derision implicit in their views of COGs, it is unsurprising that the ideal of having COGs implement Regional Strategies gained little currency. This is despite the relative merits that, from a technical perspective at least, would appear to have argued for a COG implementation scheme.

Why did Cohen and Fawbush oppose the idea of using COGs to implement Regional Strategies? Some insight into this issue is provided by Leonard (1983). He examined Oregon's experience in fashioning its system of comprehensive statewide 
land use planning during the 1970s. He concludes that many Oregonians viewed COGs as "nonlocal intervention by non elected officials." It is true that policy direction for COGs was provided by boards of directors comprised of elected officials. However, many Oregonians saw their mandates to act collectively across traditional jurisdictional boundaries as blurring the link between elected COG officials and the constituencies that elected them. This led many Oregonians to view COGs as artificial governments and COG leaders as largely unaccountable to local interests.

Section 6 [1] of HB 3011 provided that the governing board of Oregon's counties could delegate responsibility for most phases of the Strategy process to third parties. The main exception was the required public hearings. The origins of this provision remain a mystery. One possibility is, however, that this provision was aimed at compensating for the limited capacity of Oregon's counties for economic development planning, since it can be seen as having allowed counties to delegate out those administrative tasks associated with Regional Strategies for which they were incapable. In any event, it is instructive to note that a key aim of Regional Strategies was to enhance Oregon's capacity for economic development planning. However, the consequence of rejecting COGs as vehicles for implementing Regional Strategies was that this responsibility fell not upon those jurisdictions most capable of fulfilling this role, but instead on Oregon's counties, little experienced in the economic development domain. This can be seen as a constraint upon the prospects that the Regional Strategies arrangement would increase Oregon's capacity for economic development.

The T\&E Committee deliberations pertaining to establishment of multicounty regions and the rejection of COGs for implementing Regional Strategies can be seen as having been decided mainly around the issue of protecting local control. The deliberations surrounding the question of the Governor's role in establishing regions 
also comprised a manifestation of the local control issue. In effect, localism engendered constraints upon Governor Goldschmidt's prospects for autonomous action. Since Governor Goldschmidt viewed multi-lateral implementation as a capacity building measure, localism can also be seen as having engendered a prospective constraint upon the capacity building potential of the Regional Strategies arrangement. Last here, by engendering a repudiation of Oregon's COGs as vehicles for implementing Regional Strategies even though they appeared much more capable to act in this role than Oregon's counties, localism again imposed a prospective constraint upon the capacity building potential of the Regional Strategies arrangement.

\section{SUMMARY}

Discussion in this chapter highlights points to constraints upon the likelihood that Regional Strategies would boost Oregon's capacity for economic development planning and the autonomy of the governor's office. These constraints emerged as the product of the division of power between the branches of Oregon government, regionalism and localism. Also, discussion here indicates that the operational arrangements embodied in Regional Strategies provided the opportunity for use in building political support and that Oregon Governor Goldschmidt clearly aimed to use Regional Strategies towards this end. 


\section{NOTES}

1. A final enrolled copy of HB 3011 appears in Appendix A. Since revisions and amendments resulted in little change to the numbering of the bill's major sections, the reader should have little problem using this copy of refer to those sections cited in the text.

2. Discussion throughout the balance of this chapter draws heavily upon the minutes of the Joint Committee on Trade and Economic Development of the Oregon legislature.

3. Also established during EDD's restructuring was a new work force section which Bob Baugh, former Oregon AFL-CIO Secretary-Treasurer was hired to manage. We can see this as a formal acknowledgement of Goldschmidt's campaign promise to provide the unions a consultatory role in fashioning his economic development policy. 


\section{CHAPTER VI}

\section{THE POLITICS OF IMPLEMENTATION: CENTRAL OREGON}

The need to secure authorization of the Regional Strategies program in a regionally divided legislature led the Goldschmidt Administration to implement a Regional Strategies prototype in Central Oregon. The multi-county tourism strategy implemented in Central Oregon was the product of an accommodation reached between the Administration and a powerful local growth coalition. The Administration encouraged the Central Oregon counties to adopt a tourism strategy because it viewed tourism as a source of rapid job growth. It was likely to be job growth built upon a marginalized, low wage work force, however, making it unlikely that the Administration would secure a key industrial policy goal--generating family wage jobs. Central Oregon's tourism strategy made little account of the type of objective economic analysis called for in HB 3011. Success in securing Central Oregon's highest priority strategy project required that the Administration resort to highly personalized tactics to circumvent conventional channels of public authority.

\section{THE POLITICS OF PROTOTYPE CHOICE}

The three counties comprising the Central Oregon region were Deschutes, Jefferson, and Crook (Fig 1). They are located east of the Cascade Mountains, the natural barrier that has traditionally divided Oregon's most from least developed regions. Together, they covered some 7,800 square miles of land with a diverse topography ranging from the heavily forested alpine peaks of western Deschutes 
County to the high desert plateau of the region's central area. The region's 1985 population was 90,000 . Deschutes County, geographically the largest of the three counties was also the most populous, accounting for two-thirds of this total. The balance was more or less split evenly between Jefferson and Crook counties (Employment Division 1985).

In 1986, the wood products sector employed almost 21 percent of Central Oregon's work force, a figure close to that of Oregon as a whole, if the three county Portland area is excepted. Irrigated farming was also important to the region's economy, especially in Jefferson County. So was ranching, especially in Crook County, which supported a larger cattle population than any other county in Oregon. Given the resource dependent nature of Central Oregon's economy, it is unsurprising that the period leading up to 1987 was, as with most of Oregon's lesser developed areas, one of high unemployment. Crook County was probably the hardest hit. Fully one-fourth of Crook County's labor force was unemployed during the winter of 198182. The unemployment rate peaked at 20 percent in neighboring Deschutes and Jefferson Counties during this same period (Employment Division 1982). By 1985, economic conditions in Central Oregon had improved. Still, at about 11 percent, the tri-county unemployment rate remained almost 3 percentage points higher than the state-wide average. All three counties were listed as labor surplus areas by the U.S. Labor Department 1986, a distinction they shared with almost all the other counties on the east side of Oregon's Cascade Range.

In late 1986, only days after his victory at the polls in Oregon's November 1986 election, Governor-elect Goldschmidt telephoned Greg Cushman, publisher of the Bend Bulletin, the largest local newspaper in the three county Central Oregon region. According to Cushman (January 23, 1990), Goldschmidt asked him to organize business and government leaders from throughout the region for the purpose 
of identifying a collective regional economic development goal. The goal was to serve as the basis for lottery funded state assistance. The Governor-elect told Cushman that Central Oregon would serve as an example upon which the collaborative economic development efforts of other regions could be modeled. Regional Strategies was unlike past economic development practices in Oregon. By implementing a prototype strategy in Central Oregon, the Governor-elect aimed to provide local officials a precedent upon which they could model their own Regional Strategies.

There are thirty-six counties in Oregon. The selection of the three Central Oregon counties for prototypical strategy planning appears to be explained by several, primarily political, factors. These shed light on the tactics by which the Goldschmidt Administration aimed to secure its industrial policy goals.

\section{The Need for Regional Balancing}

One factor that appears to have accounted for Central Oregon's selection as a Strategy prototype was the need to secure authorization of Regional Strategies in a regionally divided legislature (McCabe October 26, 1989; Wetter November 2, 1989; Lohman November 21,1989$)$. Central Oregon was not in fact the only strategy prototype implemented. A strategy prototype was also implemented in the three county Portland metropolitan area the centerpiece of which was a downtown Convention Center. David Lohman, the Goldschmidt campaign supporter who subsequently became EDD Deputy Director made it clear that the Administration envisaged the Convention Center as the centerpiece of a Portland area Regional Strategies prototype in testimony he presented before the legislature's T\&E Committee in late January, 1987. He said the Convention Center enjoyed "enough . regional support" to be envisaged as a "prototype" strategy. 
During the campaign, Goldschmidt had pledged that if elected, he would provide state funding for Convention Center construction, which had emerged as a key goal of Portland's business establishment and, commensurately, of the Portland area legislative delegation. Linking funding for the Convention Center to Regional Strategies appears to have allowed Goldschmidt to kill two birds with one stone, enabling him to build support for Regional Strategies among Portland area lawmakers while deliberating on his campaign promise to fund Convention Center construction. Lawmakers from Oregon's less developed region's were much less enthusiastic about funding the Convention center, however. State Senator Eugene Timms made this point at a January 28,1987 hearing of T\&E Committee. Timms, who represented largely rural areas of central and eastern Oregon objected to the idea of providing state funding for the Convention center on the grounds that doing so favored "the economically healthiest areas of the state" (Oregonian January 29, 1987). Governorelect Goldschmidt appears to have believed that in order to secure authorization and funding for regional strategies from a regionally divided legislature, he needed to implement not just one prototype strategy in the Portland area but another as well, one which would appeal to lawmakers like Senator Timms from Oregon's lesser developed regions.

If Governor-elect Goldschmidt was seeking to implement a prototype strategy which would appeal to rural lawmakers, he could hardly have selected a region which was more likely to offer access to strategically positioned lawmakers than Central Oregon. In 1987, most of the three county Central Oregon region fell into legislative districts represented by one of two Oregon state Senators: Eugene Timms and Ken Jernstedt. Both sat on the all important T\&E Committee during the 1987 session of the Oregon legislature. Timms and Jernstedt were well positioned to 
play key roles in getting HB 3011 out of Committee in a form amenable to the Governor. They were conservative Republicans and might therefore be expected to be among the most strident opponents of Goldschmidt's plan to refashion state economic development policy in Oregon; Timm's objection to the selection of Portland's Convention Center as a Regional Strategies prototype has already been noted. Importantly, if metropolitan Portland is excepted, the writer was unable to identify another multi-county Regional Strategy compact incorporating an area similarly represented by more than a single lawmaker during the 1987 session of the Oregon legislature.

It is in fact quite clear that the Goldschmidt Administration recognized the instrumental role Timm's and Jernstedt could play in authorizing and funding Regional Strategies and sought deliberately to elicit their support for this purpose. As will be seen later in this chapter, in March, 1987, in the midst of hearings on HB 3011 by the T\&E Committee, Governor Goldschmidt visited the Central Oregon city of Bend for a ceremonial unveiling of Central Oregon's prototype Regional Strategy. Praising local officials for work he said deserved "something higher than an A," Goldschmidt said that the bill he had pending before the legislature was "very compatible with what is being suggested here" (Bend Bulletin March 17, 1987). Goldschmidt was clearly in bend to build support for his regional development initiative amongst the region's representatives on the T\&E Committee. This was the point Mike Freeman, a reporter from the Bend Bulletin, aimed to make in his coverage of the March 16 ceremony when he reported "both the Governor and local officials must (now) become salesmen for the program" (Oregonian March 17, 1987). Shortly thereafter the local government leaders responsible for putting the Central Oregon Strategy together met with members of the region's legislative delegation, including 
Senators Jernstedt and Timms, and urged them to support the Governor's legislative package (Prante, January 24, 1990; Allen January 25, 1990). Both Senators did in fact did do so.

The Tourism Precedent

Another reason that appears to have explained Central Oregon's selection as a prototypical Regional Strategy was the role tourism played in the areas economy. Governor-elect Goldschmidt's had a strong predisposition towards the implementation of tourism strategies. He made no secret of this, having indicated as much during his campaign in comments reported by the Oregonian:

Oregon should bring tourism to the top of the state's economic agenda in areas that choose to promote it, Neil Goldschmidt, a Democratic gubernatorial candidate, said in Bend on Friday. Goldschmidt said that of elected, he would make a personal commitment to assuring that tourism stays at the top of the state's agenda in regions that have made a choice to promote tourism. "That commitment will be...the governor's personal involvement [he said]" (Oregonian February $1,1986)$.

Four months later, the Oregonian (June 20, 1986) reported that "If elected,

Goldschmidt said the state should settle on two to four regions that could be developed as major regional or national tourists destinations."

In Central Oregon, there existed a robust tourism sector which could only be seen as providing a firm base upon which to implementing a tourism strategy, towards which the Goldschmidt Administration was strongly predisposed. As Table III shows, tourism played a greater role in Central Oregon's economy than in Oregon as a whoie. ${ }^{1}$ At 11 percent, tourism's share of total 1986 employment in Central Oregon exceeded its work force share in both the greater national and Oregon state economies. Perhaps more instructive was the robustness of Central Oregon's tourism sector. Between 1970 and 1986, the annual average rate of growth in Central Oregon's 
tourism sector was, at 15.6 percent, over twice the comparable rate for the greater U.S. and Oregon state economies. By 1986, there existed in Central Oregon a well developed tourism and recreational industry complex. The focal point was Mount Bachelor. Since 1958, when the slopes of Bachelor Butte had first been groomed and ski lifts installed, "the Mountain," as it is commonly called by locals had emerged as one of America's preeminent skiing areas. According to Mount Bachelor Inc., the corporation that operated the Mountain's ski runs and lifts, over 1.5 million skiers skied Mount Bachelor during the 1986-87 season. Surrounding Mount Bachelor was a network of visitor attractions including resorts such as the Inn at the Seventh Mountain, Sun River and Kah-Nee-Tah and a natural history museum, the High Desert Museum. Visitors came to Central Oregon to climb, hike and camp the Cascades, fish quiet sections of the Deschutes River, or raft less quiet sections, water ski on Lakes Billy Chinook and Ochoco, climb Smith Rocks, and peruse the rustic town of Sisters.

The role tourism played in Central Oregon's could be seen as providing a strong foundation upon which to base a prototypical tourism Strategy, which Goldschmidt was unequivocally in favor of. Goldschmidt himself hinted at this when he first moved to inaugurate planning for Central Oregon's prototypical strategy. According to Greg Cushman (January 23, 1990), the Central Oregon newspaper publisher Goldschmidt contacted to begin Strategy planning in Central Oregon, the Governor-elect recommended that Central Oregon make tourism the target of its Regional Strategy activities when he first asked Cushman to inaugurate Central Oregon's prototypical strategy planning process. 


\section{Strong Local Planning Capacity}

Central Oregon's strong local capacity for economic development planning also appears to have contributed to its selection as a Regional Strategies prototype. By 1986, there had evolved in Central Oregon an established regional economic development network. The nucleus of this network was the Central Oregon Economic Development Association (COED), which had been jointly formed by the three Central Oregon counties in 1981. A non-profit association funded by local businesses and government, COED served as an industrial promotion agency and economic development clearing-house for the three county area. COED lent cohesion and coordination to local economic development activities in Central Oregon. The Central Oregon Intergovernmental Council--the region's COG--was also active in economic development activities. COIC administered a business loan program in which two of the Central Oregon Counties--Jefferson and Deschutes--participated.

The Central Oregon Recreation Association (CORA) was also a key player in the region's economic development network. CORA had been established as a tourism industry trade association in the mid-1970s by Mount Bachelor and other key industry businesses. It served mainly to market local recreation attractions. In 1986, CORA did so to the tune of some $\$ 1.3$ million year. It was funded both by private businesses as well as the 20 percent share that CORA reaped of the Deschutes County room tax (EDD 1987).

Perhaps nothing better epitomized Central Oregon's strong capacity for economic development than its 1985 success in securing regularly scheduled airline service for the region. Prior to 1985 , the region had for about five years lacked regular commercial air service, this being largely a consequence of federal airline deregulation. COED, COIC and CORA joined with local governments in putting 
together a $\$ 500,000$ package needed to secure service by Pacific Southwest Airways for the region's major airport at Redmond, both Deschutes County's and the region's second largest city.

The Council for Economic Development in Oregon (CEDO) is an association of local and state economic development officials. CEDO's Director during the period in which the Central Oregon Regional Strategy was implemented was Debbie McCabe. Interviewed during the course of this research, McCabe (October 26, 1989) described Central Oregon's experience with local economic development planning in terms that led the writer to conclude that the region possessed a capacity for economic development planning probably unmatched, with the exception of the Portland area, in Oregon.

Goldschmidt envisaged the Central Oregon prototype as a model upon which other areas of the state could base their strategy planning efforts. He also aimed to use the his working prototypes as vehicles for lobbying legislative authorization of his regional development program. To meet these aims, the prototype strategy had to be up an running quickly, both so as to demonstrate progress within the constraints posed by a short legislative session, scheduled from January through early June, 1987, and to establish precedents upon which the collaborative strategy efforts of other areas could indeed be modeled. A prototype couldn't get bogged down early on in organizational difficulties if it was to serve its purpose. By all appearances, Central Oregon's strong economic development network offered exactly the type of institutional structure necessary to meet this imperative. 


\section{TOURISM AS AN EMERGING INDUSTRY}

Governor Goldschmidt believed that Oregon's tourism sector could fueled rapid job growth. Examining the reliability of this claim is important for two reasons. First, because it sheds light on the degree to which the decisions that shaped the Regional Strategies program were based upon objective economic analysis. Second, because it sheds light on the degree to which the Regional Strategies program aimed to promote growth in emerging industries. The Analysis offered suggests that Oregon's tourism sector was indeed likely to serve as the source of rapid job growth. Still, if tourism was an industry with prospects for rapid job growth, it was likely to be job growth built, however, upon a marginalized, low wage work force.

Governor Goldschmidt viewed tourism promotion not only as a vehicle for generating jobs within the tourism sector itself. He believed that promoting tourism could expand employment in other industries as well. This view was based upon a view of "tourism as a hook:" that tourists attracted to an area while visiting might later return permanently to live and work and set into motion the multiplier associated with the full range of services the new resident might need. Goldschmidt Administration officials saw tourism as a vehicle for promoting economic diversification in timber dependent areas and insulating these areas against a repeat of the dismal circumstances they experienced during the first half of the 1980s (Wetter November 2, 1989;

Lohman November 21, 1989).

Materials published by the Goldschmidt campaign endorsed this view. For example, the Goldschmidt campaign published a 60 page document titled "The Oregon Comeback," intended to lay out the candidate's economic recovery plan. It stated that promoting tourism would produce "a high return for state investment" and 
that "tourism continues to create jobs whether other parts of the economy rise or fall" (Goldschmidt Campaign nd). However, this campaign document contained no data to substantiate the view of tourism as a anti-cyclical industry. In fact, it appears that the Goldschmidt campaign's claims about the robustness of tourism were shaped not by first-hand analysis but by rhetorical advice received from campaign advisers (Bragdon October 31, 1989; Wetter November 2, 1989). ${ }^{2}$

I decided to independently assess the degree to which tourism is likely to serve as the source of rapid job growth. The literature has typically defined emerging industries in either of two terms. One is in terms of industries that produce high value added goods. The other is in terms of industries with prospects for high rates of employment growth. As regards tourism, the latter definition appears most applicable, since it was in terms of job growth that the Goldschmidt Administration's preference for tourism was couched. As Table III shows, job growth in the tourism sector has mostly outpaced overall job growth rates by significant margins, supporting a view of tourism as an emerging industry. As regards the Administration's claim that tourism employment is anti-cyclical, however, the picture is mixed. Nationwide, the tourism sector added jobs during the recessionary period 1980-82 while the overall economy contracted. But growth in tourism related employment was slow and the difference between tourism sector and overall economic performance was not great. Furthermore, in Oregon, tourism employment declined during this period. Granted, the decline in tourism jobs was less precipitous than in overall employment. In heavily tourist dependent Central Oregon, tourism sector employment declined more precipitously than did overall employment, contravening the claim that tourism was likely to act as an anti-recessionary buffer. The Oregon figures certainly provide little support for the view of tourism as a job gainer during recession. 
TABLE III

SELECTED EMPLOYMENT FIGURES FOR

THE UNITED STATES, OREGON

AND CENTRAL OREGON

Industry Share of Total Employınent

Annual Average Employment Growth Rate

1970-1986 1982-1986 1980-1982 Recession

Wood

Products Tourisın

Overall

Tourisın

Overall

Tourism

Overall

Tourisin

USA

$0.8 \%$

$8.3 \%$

$2.9 \%$

$7.1 \%$

$2.3 \%$

$4.9 \%$

$-0.4 \%$

$1.8 \%$

Oregon

$7.0 \%$

$9.7 \%$

$3.7 \%$

$7.3 \%$

$28 \%$

$2.0 \%$

$-4.9 \%$

$-3.7 \%$

Central Oregon

$20.9 \%$

$11.0 \%$

$10.4 \%$

$15.6 \%$

$7.4 \%$

$6.3 \%$

$-6.5 \%$

$-7.0 \%$

Source: U.S. Census Bureau, County Business Patterns

Wood Products employment defined as SIC 24 (Lumber and Wood Products)

Tourism employment defined as SIC 58 (Eating and Drinking Places) and SIC 70) (Hotel and Lodging Places) 


\section{The Character of Private Investment as a Limit Upon State Autonomy}

The Goldschmidt Administration embraced tourism strategies as a vehicle for promoting economic restructuring and creating jobs. By and large, the tourism sector appears to have been characterized by rapid job growth. Yet, it is clear that the Goldschmidt Administration's industrial policy aimed not simply to generate job growth but to generate jobs of a certain character. Language contained in HB 3011 makes this clear. It mandated that local strategy selection be guided by the goal of creating "family wage jobs," a term defined with precision as "a full time equivalent job with a wage greater than 80 percent of the median income for a family of two in the county where the majority of employees reside" (EDD nd a). In light of this provision, it is also worthwhile to look at tourism from a wage perspective. Doing so points to the character of private capital investment as a probable limit upon the likelihood that the Goldschmidt Administration would secure this key industrial policy goals. For there is considerable evidence to support the view that promoting tourism in Oregon was unlikely to generate the type of family wage jobs called for in the Regional Strategies program's founding legislation.

As will be seen shortly, Central Oregon did implement a tourism strategy. Subsequently, the Oregon Employment Division generated estimates of the income likely to be derived by workers in jobs generated by the Strategy. The results were communicated in an addressed memorandum from a certain T.L. of the Research and Statistics section of the Oregon State Employment Division dated February 3, 1988. It read in part:

Our analysis indicates that approximately fifteen percent of the permanent jobs created by [implementing a tourism strategy in central Oregon] would exceed the proposed $\$ 15,400$ family wage standard established for the three county region. If customer tips were to be included for those occupations where tipping is customary (i.e., waiters 
and waitresses, bartenders, etc.) then their annual wages would increase by approximately fifty percent. This would raise the wage base of many of these permanent jobs but would not cause a significant increase in the number of jobs exceeding the $\$ 15,400$ standard.

There is additional evidence with which to judge the wage levels affiliated with promoting tourism in Central Oregon. In 1986, the annual average wage in Deschutes County was $\$ 15,847$; this compared unfavorably to both Crook $(\$ 17,698)$ and Jefferson $(\$ 16,777)$ counties. By most accounts, the low position Deschutes County occupied in the region's wage structure was attributable to the depressing effect of tourism related jobs (EDD 1987). Most tourism industry jobs are concentrated in either of two sectors: retail or services. Also, while as noted earlier, it is difficult to define tourism per-say, most tourism-related jobs are concentrated in either of two areas of economic activity, retail or services--the lowest wage sectors of business activity. For example, in 1987, annual wages in Deschutes County's retail $(\$ 10,842)$ and service $(\$ 13,37)$ sectors compared very poorly to wages in the County's manufacturing $(\$ 19,430)$ and construction $(\$ 18,957)$ sectors.

In sum, most of the jobs likely to be created by promoting tourism in Central Oregon would likely fail to meet the family wage standard. Several reasons are cited in explaining why tourism likely to be the source of low wage employment. For one thing, the tourism industry is associated predominantly with low wage sectors demanding unskilled or only semi-skilled laborers. Also, much tourism industry employment is part time. For example, in 1987, 49 percent of jobs in Oregon's recreation and entertainment sectors were part time. The figure in retail was 31 percent. In contrast, only 12 percent of Oregon's manufacturing sector job force worked part time (EDD 1987). Many tourism related jobs are seasonal as well.

The issue of low wages in the does not appear to have been raised amid deliberations over selecting tourism as Central Oregon's Strategy. This is not to say 
that architects of Central.Oregon's strategy were not oblivious to the fact that tourism was likely to create low wage jobs. They were obviously aware of this, a point they acknowledged in the Strategy document they put together after the decision on the tourism strategy had been reached. Central Oregon's Strategy document acknowledged that "Low wages associated with most tourism related occupations is an object of concern." Consequently, the question was posed: "Should the wage problem constitute a barrier to the consideration of tourism as an economic development strategy?" Central Oregon's response: "We think not." This finding was based upon the following reasoning, which the writer has excerpted from the Central Oregon Strategy document:

Currently, more than 60 percent of women and children under the age of 18 are in the labor force. With the two earner family rapidly becoming a national norm, the combined income resulting from one family member, for example, holding a $\$ 9$ per hour job in manufacturing and the other holding a $\$ 4$ per hour tourist related job will provide a family income in excess of $\$ 27,000$ annually. Logically, therefore any future analysis of job creation must consider the reality of the two earner family. Acceptance of this argument largely negates the low wage barrier against tourism as an economic development strategy.

The reasoning articulated by the architects of Central Oregon's strategy suggests that if implementing a tourism strategy in Central Oregon held forth the prospects of potentially rapid job growth, it was likely to be job growth built upon a marginalized, low wage work force. Perhaps more instructively, in light of that provision of HB 3011 that provided for strategy selection to be based upon the potential for generating family wage jobs, it appears that in championing tourism as a regional development strategy, the Goldschmidt Administration effectively cast favor upon an industry that was by its very nature, unlikely to provide the type of jobs called for in its own industrial policy guidelines. 


\section{THE POLITICS OF TOURISM STRATEGY SELECTION}

\section{The process of implementing Regional Strategies in Central Oregon was}

initiated by way of a November, 1987, telephone call from Governor-Goldschmidt to Greg Cushman. Goldschmidt asked the publisher of Central Oregon's largest newspaper to organize a meeting of local business and government leaders for the purpose of identifying an economic development strategy for the three county Central Oregon region. In closing, Goldschmidt asked that a statement outlining the region's selected goal be ready for his review by December 15, 1987.

Responding to the Goldschmidt's overture, Cushman called together business and government leaders from throughout the tri-county area: They met at the Redmond Golf Club on November 25, 1987. According to a report that appeared in the November 26, 1986 edition of the Bend Bulletin (November 26, 1986), the meeting was attended by about 60 people, who were:

clearly uneasy when they gathered in Redmond Tuesday to identify regional needs that Goldschmnidt could help them achieve. The potential conflicts were obvious: the various communities in Deschutes, Crook, and Jefferson Counties do not all share the same goals or face the same problems.

The November 26 edition of the Bend Bulletin continued to report that "the recommendations from Tuesday's meeting will be written up by a subcommittee of seven local leaders next week and presented to Goldschmidt's "transition team" by December 15."

In the aftermath of the Redmond meeting, the Central Oregon leaders prepared a memorandum. It was sent to Goldschmidt by the December 15 deadline he had specified. The essential feature of the memorandum was captured in the Bend Bulletin's January 7, 1987, edition. It reported that the memorandum: 
stressed developing tourism to sell Central Oregon. The economic goal for the region is to develop a diversified economic base, the report said. Tourism will bring people to the area, possibly convincing business leaders from outside the region to locate here.

To help the region promote tourism, the memorandum sought state assistance in three areas: construction of a tourism information center; cash grants to local agencies which would use the money in promoting Central Oregon's tourist attractions and for business recruitment; and selected highway improvements. The projects for which Central Oregon sought state assistance under the aegis of Regional Strategies will be examined later in this chapter. At this juncture, consider instead the following four points.

First, the term "Regional Strategies" does not appear to have gained common usage in relation to Goldschmidt's economic policy initiative until January, 1987, a month after the Central Oregon memorandum was sent to Goldschmidt's transition team. For this reason, the words "Regional Strategy" were never used in connection with the memorandum. Nonetheless, the practical effect of the memorandum was to target tourism as Central Oregon's Regional Strategy.

Second, Governor-elect Goldschmidt emphasized expeditiousness in inaugurating Central Oregon's Regional Strategy. Central Oregon had little more than a month in which to select its target industry. Goldschmidt's timetable appears to have been driven primarily by political concerns, specifically his desire to have an incipient Strategy ready for the opening of the 1987 session of the Oregon legislature, in January, 1987.

Third, fewer than three weeks passed between the time Governor-elect Goldschmidt asked Greg Cushman to inaugurate a strategy process in Central Oregon and the meeting at the Redmond Golf Club. Fewer than twenty more days passed between this meeting and the December 15 deadline by which the memorandum 
identifying tourism as Central Oregon's Strategy was sent to the Goldschmidt team. It should be clear that the time frame within which Central Oregon's target industry was chosen left little time for conducting the type of economic analysis upon which Strategy selection was supposed to be based. In fact, there is no evidence to indicate that economic analysis played any role at all in the decision to target tourism as Central Oregon's Regional Strategy or even that any such analysis was attempted prior to Central Oregon's decision to target tourism.

That the selection of tourism as Central Oregon's Regional Strategy eschewed any sort of economic analysis leads to the fourth point to be made at this juncture. This is that the process by which decision was reached on targeting tourism as Central Oregon's Strategy was wholly a function of political accommodation. It is towards examining this argument that discussion now turns.

\section{Bifurcated Support for Tourism}

The memorandum that emerged from the November, 1987 meeting held at the Redmond Golf Club established tourism as Central Oregon's Regional Strategy. Enthusiasm for a tourism strategy varied widely within the region. While support for a tourism strategy was strong among officials representing Deschutes County and the city of Bend, elsewhere the tourism strategy was largely greeted with ambivalence or in some cases, derision (Kozak January 11, 1990; Uffleman January 24, 1990; Rick Allen January 25, 1990; Prante January 24, 1990; (Riggs January 25, 1990; Comini January 24, 1990; Cushman January 23, 1990; Hollern January 24, 1990; Dobert January 11,1990 ). The strong support tourism received from officials representing Deschutes County and Bend is largely explained by the role this area played in the region's tourism sector. Deschutes County dominated Central Oregon's tourism 
sector. It was in Deschutes County that Mount Bachelor, the centerpiece of Central Oregon's tourism sector, was located. And it was in Bend, the seat of Deschutes County government, that the tourism sector was headquartered.

Table IV depicts the extent to Deschutes County dominated Central Oregon's tourism sector. In 1986, Deschutes County accounted for 87 percent of Central Oregon's tourism related employment. Deschutes County also accounted for over 95 percent of total regional tourism sector employment growth between 1970 and 1986 . Located twenty miles from Mount Bachelor, Bend was home to most of the lodging, dining and entertainment, shopping and ancillary facilities that served visitors to Central Oregon. Fueled by growth in the area's tourism industry, Bend had, by 1986, grown to encompass within its city limits a population of 18,000 . Almost as many people lived in unincorporated communities surrounding the city giving the Bend urban area a population of almost 36,000 . This made Bend not only the largest community in Central Oregon, but the largest in Oregon west of the Cascades Mountains (Census for Population Research and Census 1985). By 1986, Bend had emerged not only as the headquarters of Central Oregon's tourism network but in the larger sense the regional business and consumer services center as well.

Areas.peripheral to the core tourist attractions surrounding Bend also attracted visitors to Central Oregon. But tourism in these areas differed from that affiliated with the Bend area. The tourism attractions affiliated with Bend were highly concentrated and depended upon high value added attractions: Mount Bachelor, resorts such as Sun River and the Inn at the Seventh Mountain and restaurants, lodging and entertainment facilities. Elsewhere, the tourism sector was highly diffuse and revolved mainly around low value added outdoor activities--rafting and fishing, 
TABLE IV

DISTRIBUTION OF TOURISM RELATED EMPLOYMENT,

TRAVEL GENERATED PAYROLL PER-CAPITA

AND TOTAL TRAVEL EXPENDITURES IN

CENTRAL OREGON

\% SHARE OF 1986

REGIONAL TOURISM EMPLOYMENT

\section{\% SHARE REGIONAL \\ TOURISM JOB}

TOTAL 1985

TRAVEL

GROWTH 1970)-1986
TRAVEL GENERATED
PAYROLL

PER-CAPITA 1985

\begin{abstract}
Deschutes County
Jefferson County

Oregon Stattewide
\end{abstract}

$86.8 \%$

$95.9 \%$

$\$ 140,672,000$

$\$ 445$

$7.2 \%$

2. $1 \%$

$\$ 4.250,000$

$\$ 7,953.0010$

$2.11 \%$

$\$ 2,519,797,(1010$

$6.11 \%$

Notes:

Tourism conployment defined as SIC 58 (Eating and Drinking Places) and SIC 70 (Hotel and Lodging Places)

Source: U.S. Census Bureau; Oregon Economic Development Department 
camping, water skiing in state parks or in the case of the town of Sisters, perusing a rustic town set in the foothills of the Cascade Mountains.

Some sense of the bifurcated nature of Central Oregon's tourism sector is conveyed in the figure on total travel expenditures presented in Table IV. In 1985, the most recent years for which data was available at the time of this writing, total travel expenditures in Deschutes County exceeded $\$ 140$ million. This exceeded the combined total for Crook and Jefferson Counties by over ten times. Another measure of the bifurcated nature of Central Oregon's tourism sector lies in a comparison of figures on travel generated payroll per-capita--total travel payroll divided by population. While imperfect, figures on travel generated payroll per-capita do nonetheless provide some measure of the intensiveness of an area's travel sector. Higher travel generated payroll per-capita figures should correlate with areas possessing more intensive tourism sectors and vice-versa. As Table IV shows, the 1985 figure for Deschutes County's territorially concentrated, high value added attractions was $\$ 445$. In other words, Deschutes County's tourism sector generated $\$ 445$ in payroll for each resident of the County, a figure 136 percent above the statewide average (\$199). The comparable figures for Crook and Jefferson Counties, with their less value-added, capital intensive tourism industries, were $\$ 121$ and $\$ 65$ respectively, significantly less not only than the Deschutes County figure but well below the statewide average as well.

Among local officials interviewed during the course of this research, there was a widely shared perception that under a strategy which promoted Central Oregon's tourism sector, the lion's share of Strategy funding and resulting benefits were likely to be concentrated in Western Deschutes County and in and around the City of Bend, the focal point of the region's tourism sector. Deschutes County's 
second city, Redmond, while possessing little in the way of a tourist attractions, might also expect some benefit under a tourism Strategy. If industrialists decided to relocate to the area after visiting as supposed, some might be expected to do so in Redmond, which had emerged as something of an "industrial satellite" to Bend. But Jefferson and Crook Counties, it was widely agreed, were likely to derive only marginal benefits from promoting tourism. Excepting park lands, these areas possessed little in the way of visitor destinations. Madras and Prineville, the two largest cities in these counties, were each located a considerable distance from Bend vicinity recreation attractions and were therefore considered unlikely to experience either direct expansion of local tourism businesses or indirect growth due to relocations of the sort envisaged by Goldschmidt Administration officials.

\section{The Key Actors}

One way to explain how Central Oregon decided to target tourism as its Regional Strategy is to explore the role played by three individuals who, by all accounts, played pivotal roles in the tourism strategy selection. One is Greg Cushman, publisher the region's largest newspaper, the Bend Bulletin. Mike Hollern, President of Brooks Resources, one of Central Oregon's largest property developers, is the second. The third is Lois Bristow Prante, Chair of the Deschutes County Board of County Commissioners. Together, they personified a local growth coalition which mobilized to dominate implementation of Regional Strategies in Central Oregon. Greg Cushman was not only publisher of Central Oregon's largest local newspaper. He was also President of COED, the regional economic development agency and an influential leader of the Bend area business community. He proved himself a strong supporter of the tourism strategy. He made this point unequivocally in an editorial his newspaper published endorsing the selection of a tourism Strategy 
(EDD 1987): By all appearances, Cushman had an interest in seeing Central Oregon adopt a tourism strategy. Tourism was likely to fuel growth in the Bend area, and if past experience was any indicator, Cushman's newspaper was a likely beneficiary of this growth: the period between 1970 and 1986 saw rapid growth in the Bend area's population fuel rapid growth in the circulation of the Bend Bulletin, which doubled from 10,000 to 20,000 during this period (Cushman January 23, 1990).

Like Greg Cushman, Mike Hollern, President of Brooks Resources was a leader of the Bend area business community. Like Cushman, he sat on the COED Board of Directors. Hollern was not only a prominent Bend area businessman. He was also a close Goldschmidt associate. Documents provided by the Oregon Secretary of State's office (nd) show that he personally contributed over $\$ 8,000$ to Goldschmidt's gubernatorial campaign. With Goldschmidt's victory at the polls, he was rumored to be in line for appointment as Chairman of the Oregon Transportation Commission, the body that oversaw state highway spending. Hollern was in fact appointed Transportation Commission head in mid-1987.

By all accounts, Deschutes County Commissioner Lois Prante was the most powerful politician in Central Oregon. As Chair of the Deschutes County Board of County Commission, she presided over the largest local government entity in Central Oregon and was the only full-time elected local government executive in the three county region (Riggs January 25, 1990; Uffleman January 24, 1990; Allen January 25, 1990). Like Cushman and Hollern, she sat on the COED Board by Directors, by right of the contribution Deschutes County made to funding the body. Prante also occupied a seat on the governing body of CORA, the Central Oregon Recreation Association, which she similarly warranted on account of the 20 percent share of the Deschutes County room tax earmarked for CORA. Prante also occupied a seat on the governing 
body of CORA, the Central Oregon Recreation Association, a position warranted by the 20 percent share of the Deschutes County room tax earmarked for CORA. On CORA's board, she joined representatives from Mount Bachelor Inc., the Inn at the Seventh Mountain, and other key Bend area tourism businesses, all strong tourism strategy supporters.

Both Cushman and Hollern were well positioned to influence the strategy selection process. Both members of the public-private subcommittee that, in the wake of the November 25 meeting at the Redmond Golf Club, decided to select tourism as Central Oregon's Strategy. In part, Cushman's influence in the strategy selection process stemmed from the fact that it was he who Governor Goldschmidt contacted to inaugurate the Central Oregon Strategy process. Cushman conveyed to the assembly the Governor's recommendation that Central Oregon consider tourism as its Regional Strategy. The tone of Cushman's conveyance was such that officials from Jefferson and Crook Counties interpreted Goldschmidt's recommendation as less a recommendation than a dictum (Allen January 25, 1990; Uffleman January 24, 1990; Riggs January 25, 1990; Comini, January 24, 1990). The period leading up to 1986 had been one of economic duress for Jefferson and Crook Counties. Officials from these areas believed that the Governor was intent upon delivering a Regional Strategies prototype to the legislature on his own terms. Apprehensive as they might have been over selection of a tourism strategy, these officials saw little reason to oppose selection of a tourism strategy and risk antagonizing the incoming Goldschmidt Administration. If nothing else, these officials apparently thought, by acquiescing to a tourism strategy seemingly favored by Goldschmidt, they might accumulate political capital for future dealings with the incoming administration.

Officials from Jefferson and Crook Counties clearly had this aim in mind when, despite their misgivings, they agreed albeit unenthusiastically to back tourism 
as Central Oregon's Strategy. Madras Mayor Rick Allen (January 25, 1990) said, when interviewed, that he aimed to use his acquiescence to a tourism Strategy to leverage tangential benefits from the new administration in the form of funds with which to enhance the city's industrial recruitment activities. Redmond Mayor Bob Riggs (January 25, 1990) explained his decision to support tourism in similar terms. Recall that the memorandum sent to Goldschmidt's transition team in December, 1986 contained a request for funding with which to conduct industrial recruitment. As will be seen later in this chapter, the failure of the Goldschmidt Administration to produce this money almost torpedoed the agreement among the Central Oregon counties to implement a tourism strategy.

Hollern also played an important role in the selection of a tourism strategy, if one perhaps less conspicuous than Cushman's. Recall that the memorandum advising Goldschmidt of the decision to target tourism as Central Oregon's strategy sought highway improvements for the region. As shall be seen, support for the highway improvements was widespread not only in Deschutes County but in Jefferson County as well--the highway for which improvements were requested ran right through the middle of Madras, the County seat. At least one official from Jefferson County admitted to having been swayed from opposing a tourism strategy which he otherwise saw as likely to yield only marginal benefits for the community he represented by the likelihood that Hollern would become Transportation Commission head and thus be in a position to deliver sought after highway improvements (Allen January 25, 1990). In assessing the propriety of a tourism strategy, Allen appears to have figured that the more responsive he was to Hollern's advocacy of a tourism strategy, the greater the likelihood that the highway improvements would be constructed. His inclination in this matter might have been shared by other officials from Jefferson and Crook Counties as well. 
Greg Cushman and Mike Hollern notwithstanding, probably no local actor exercised as pervasive an influence upon Central Oregon's Regional Strategy as Deschutes County Commissioner Lois Prante. She was also a member of the subcommittee that drafted the December, 1986 memorandum to Goldschmidt that identified tourism as Central Oregon's Regional Strategy. Above all, Prante's influence stemmed from her role as Chairman of what came to be known as the Group of Seven. The Group was formed as a successor to the subcommittee that grew out of the November 25 meeting at the Redmond Golf Club. With the appointment of the Group of Seven, the sub-committee ceased to exist.

There were two significant differences between the Group and the subcommittee. First, the subcommittee's mission had been to select a strategy for Central Oregon. The Group's purpose was to select projects for funding under the region's allocation of lottery money. Second, whereas the subcommittee was an ad-hoc group composed of local government and private industry leaders, the Group of Seven was composed solely of local government leaders. The Group's composition is important. It was composed of one county commissioner from each of the three Central Oregon counties plus the mayors of the region's four largest cities--Bend and Redmond in Deschutes County, Madras in Jefferson County and Prineville in Crook County. There was an implicit balancing in this arrangement; it appears to have afforded Jefferson and Crook Counties protection from being dominated by more populous Deschutes County since if officials from the two former counties voted as a block, they could carry or veto any decision they found disagreeable.

Prante's selection as Group chair reflected the fact that as head of Deschutes County government, she was the only full-time elected local government executive in the three county region (Riggs January 25, 1990; Uffleman January 24, 1990). Alone 
among the Committee members, Prante did not have other occupational demands upon her time. Hence, she was the one with the most time to dedicate towards strategy preparation. In the Deschutes County government apparatus, she also commanded administrative resources well in excess of those commanded by the other committee members. (Freeman January 10, 1990; Kozak January 11, 1990; Uffleman January 24, 1990; Riggs January 25, 1990; Comini January 24, 1990). Subsequent to her selection as Group of Seven Chair-person, Prante's office would oversee most facets of putting the final touches on Central Oregon's Regional Strategy including playing host to all Group of Seven meetings and preparing Group meeting agendas and drafting of the final Strategy document, including the region's project list.

Just days after his inauguration as Oregon's thirty-third Governor on January 4,1987 , Neil Goldschmidt called upon the Committee of Seven to meet with him in Salem. He began the meeting by affirming his support for Central Oregon's decision to select a tourism Strategy. He also voiced support for including highway improvements in Central Oregon's Strategy. He then asked the officials to prepare a detailed list of private sector and local government projects which, leveraged by an expected $\$ 500,000$ in state lottery money, could expand the area's tourism sector. $\mathrm{He}$ asked the committee officials to have the project list completed by March 15. Last, Governor Goldschmidt said that the lottery money would not be available unless legislators adopted his regional development package. He asked the Committee to assist him in securing legislative approval (Prante January 24, 1990; Allen January 25, 1990; Kozak January 11, 1990), as he would do again at the March 15 ceremony in Bend at which Central Oregon's prototype strategy was first unveiled.

Shortly after meeting with Governor Goldschmidt in Salem, the Group of Seven assembled in the Bend office of Deschutes County Commissioner Lois Prante. 
Several dimension of the role Prante played in the Group of Seven's deliberations are instructive. One is the manner in which a dispute over how the region's allotment of lottery money would be spent was resolved. The dispute stemmed from a proposal by officials from Jefferson and Crook County's that the region's lottery money be divided up-front between the three counties on a per-capita basis. Officials from each county would then have been responsible for selecting Strategy projects to fund with their own respective shares. The driving force behind this proposal was the view, prevalent among the Group's Jefferson and Crook County contingents, that under a tourism strategy, any formula for dividing the lottery money that was based upon competitive criteria would inherently favor Deschutes County. Sponsoring officials viewed a percapita arrangement as ensuring the communities they represented a fair share of state lottery dollars. To the apparent consternation of these officials, however, the percapita scheme was rejected at the behest of Commissioner Prante (Comini January 24, 1990; Allen January 25, 1990).

The rejection of the per-capita arrangement is interesting, especially in light of the Group of Seven's composition. It would seemingly have invested officials from Jefferson and Crook Counties with the power to override Prante. Yet, no move to override seems to have arisen. According to local officials, Commissioner Prante cited the authority of the Governor in vetoing the per-capita scheme (Comini January 24, 1990; Riggs January 25, 1990; Allen January 25, 1990). Goldschmidt was certainly opposed to a per-capita division of lottery money--he wanted Strategy submissions competitively evaluated. Operating under the belief that the Governor had, in effect, mandated a tourism Strategy for Central Oregon and not wanting to risk upsetting the Governor for fear of undermining the ancillary benefits they hoped to derive, officials from Jefferson and Crook Counties did not seek to override Commissioner Prante's veto of the per-capita scheme. 


\section{The Growth Coalition}

Not all parties involved in the Central Oregon stategy were equal. Actors affiliated with the Bend area exercised the critical initiative in making tourism the region's Strategy. Officials from Jefferson and Crook Counties were relegated to a subordinate role. The private and public actors that dominated strategy selection in Central Oregon were linked by formal and informal ties. They shared an interest with Governor Goldschmidt over adopting a tourism strategy as well. The network within which these actors operated fits the classic depiction of a growth coalition. Recall that Logan and Molotch (19876:34-35) defined growth coalitions as coalitions "of interest, recruited and organized along territorial lines...to attract scarce capital." In fact, it would perhaps be hard to find a better personification of a growth coalition than that represented by the three main actors who the writer has focused upon here: Cushman, the newspaper publisher, Hollern, a developer and Prante, the County executive. Logan and Molotch identify newspapers, developers and local politicians as key players in growth coalition politics.

According to Bend Bulletin Reporter Mike Freeman (January 10, 1990), most of the Group of Seven meetings were held surreptitiously--no advance public notice was issued, the press was uninvited and no minutes were kept. Freeman said that Commissioner Prante resisted his efforts to open the meetings up. Surreptitious meetings were in fact a violation of Oregon's open meetings laws, which mandates that meetings at which three or more elected officials discuss public business be open to the public. According to Freeman, Prante complied with the law only after being apprised of the need to do so by the Deschutes County Attorney. By then, however, the essential work of putting together Central Oregon's Strategy project list appears to have been over. Freeman's account of surreptitious meetings was corroborated in 
interviews with several Group of Seven members (Comini January 24, 1990; Riggs

January 25, 1990; Allen January 25, 1990).

Further corroborating Freeman's contention that the Group of Seven meetings were, for the most part, surreptitious events were the public hearings the Central Oregon counties held on their tourism strategy. HB 3011 was adopted by the legislature in late May, 1987. Recall that the Act required counties to conduct formal public hearings prior to final selection of a strategy. The Central Oregon counties had not held such hearings. In fact,even the Strategy project list had been chosen prior to the required hearing. The passage of $\mathrm{HB} 3011$ required that such hearings be held, however, and they were, retroactively.

Jefferson County Commissioners scheduled a public hearing on the County's Strategy for July 1, 1988. A review of the hearing's minutes showed that fifteen minutes lapsed between the time at which the hearing was convened and closed, during which not a single person appeared to offer testimony. Nor did anyone testify at the Strategy hearing held a week later at the Crook County courthouse in Prineville. Deschutes County's hearing was only slightly better attended. Two witnesses appeared before the County Board of Commissioners to offer testimony on the propriety of making tourism central Oregon's Strategy. They were not there to challenge the Strategy however but to endorse it, however. The two were Peter Dobert and Meaghan Dobert. He was COED's executive director; she executive director of CORA, the association of recreation industry interests. Each read a short statement expressing their support for the tourism strategy. ${ }^{3}$ The lack of public participation in the hearings held on the Central Oregon strategy can be seen as wholly indicative of a process which was, as the Bend Bulletin's Freeman and others claimed, essentially removed from public view. 
The surreptitiousness that surrounded the Central Oregon Strategy interesting. It indicates that in its behavior, the Central Oregon growth coalition mirrored the behavior of other growth coalitions depicted in the literature by a number of authors. Included are Hartman (1984), Swanstrom (1985), and Fainstein et al. (1986).

\section{LESSONS FROM THE PROJECT LIST}

The Group of Seven's primary job was to assemble a list of projects for funding under Central Oregon's Regional Strategy. The January 23, 1987 edition of the Bend Bulletin reported the criteria upon which the Group decided to judge projects proposed for funding under the Strategy. Included were the relevance of the proposal to tourism, matching funds, the number of people the project would reach, the yearround impact of the proposed project and the tri-county impact of the project. Interestingly, the number of jobs to be created, either directly in tourism or downstream in terms of firm relocations, received no mention. This does not lend itself well to the conclusion that in making decisions on selecting Strategy projects, the Committee adhered rigorously to a set of objective principles.

Table V summarizes Central Oregon's final Strategy project list. Analysis of the project list provides the opportunity to address a number of issues with which this dissertation is concerned. Included are the extent to which Regional Strategies was characterized by institutional cohesion and the avenues by which Governor Goldschmidt sought to use the authority he was vested with to override sectional interests and how the relative capacities of local governments for economic development planning affected the Strategy process. 
TABLE V

CENTRAL OREGON REGIONAL STRATEGY PROJECT LIST

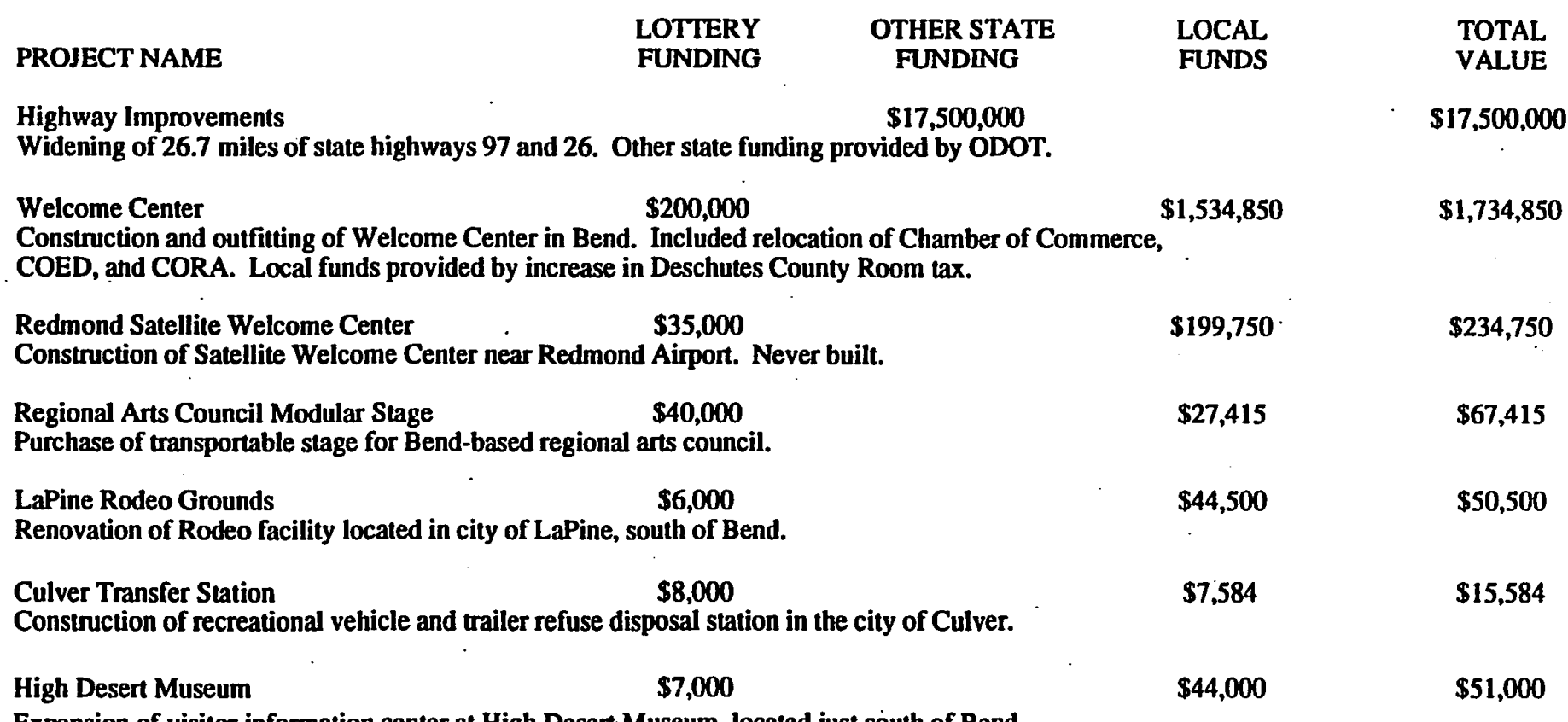

Expansion of visitor information center at High Desert Museum, located just south of Bend. 
TABLE V

CENTRAL OREGON REGIONAL STRATEGY PROJECT LIST

(continued)

\begin{tabular}{|c|c|c|c|}
\hline PROJECT NAME & $\begin{array}{l}\text { OTHER STATE } \\
\text { FUNDING }\end{array}$ & $\begin{array}{l}\text { LOCAL } \\
\text { FUNDS }\end{array}$ & $\begin{array}{l}\text { TOTAL } \\
\text { VALUE }\end{array}$ \\
\hline $\begin{array}{l}\text { Prineville Theatre } \\
\text { Renovation of Prineville Theatre. Never completed. }\end{array}$ & $\$ 30,000$ & $\$ 19,900$ & $\$ 49,900$ \\
\hline $\begin{array}{l}\text { Media Package } \\
\text { Development of slide show and brocheure to market re }\end{array}$ & $\begin{array}{l}\$ 45,000 \\
\text { gion's visitor attractions. }\end{array}$ & $\$ 75,000$ & $\$ 120,000$ \\
\hline $\begin{array}{l}\text { Reservation Center } \\
\text { Computerized reservation center sponsored by Mount }\end{array}$ & $\begin{array}{l}\$ 65,000 \\
\text { Bachelor. }\end{array}$ & $\$ 277,000$ & $\$ 342,000$ \\
\hline $\begin{array}{l}\text { Madras Highway Reader Sign } \\
\text { Electronic highway reader sign. Never Built. . }\end{array}$ & $\$ 35,000$ & & $\$ 35,000$ \\
\hline $\begin{array}{l}\text { COED Industrial Development Campaign } \\
\text { Development of hotel lobby displays, hotel room guest } \\
\text { Also paid for purchase of computer hardware and softu }\end{array}$ & $\begin{array}{l}\$ 215,000 \\
\text { directories, and marketing brocheures. } \\
\text { vare for COED. . }\end{array}$ & $\$ 135,000$ & $\$ 350,000$ \\
\hline Total Funding: & $\$ 686,000$ & $\$ 2,364,999$ & $\$ 3,050,999$ \\
\hline
\end{tabular}


Local Capacity for Economic Development Planning Revisited

Late January, 1987 saw the Group of Seven officials announce the process by which they aimed to solicit projects proposed for funding under Central Oregon's Strategy. Prospective sponsors were directed to submit proposals to the office of one of the Group members by February 20 . This gave interested parties about thirty days to prepare and submit proposals. It's unclear as to exactly how many proposals were submitted by the February 20 deadline although it appears that there were at least fifteen. What is clear is that most of the proposals for Strategy funding originated from Deschutes County. On the day preceding the February 20 deadline, Deschutes County Commissioner Lois Prante was quoted as saying they "hadn't (yet) received (any) proposals from Jefferson and Crook Counties" (Bend Bulletin February 20, 1987).

Table V lends additional testimony to the preponderant role afforded Deschutes County in Central Oregon's Strategy. Of the fourteen projects slated for funding under the Strategy, five were sponsored either by two of the Central Oregon Counties (the highway improvements) or by agencies ostensibly serving all three of the counties (the Media Package; the COED projects; and Arts Stage). Of the money allocated to the remaining eight projects, $\$ 278,000$ accrued to Deschutes County, $\$ 58,000$ to Jefferson County and $\$ 30,000$ to Crook County. In fact, as shall be seen shortly, not all the projects listed in Table $\mathrm{V}$ came to fruition. If unrealized projects are excluded, Deschutes County's lottery totaled $\$ 230,000$ and Jefferson County's, $\$ 23,000$. In per-capita terms, Deschutes County benefited from the spending of about $\$ 3.55$ per-resident in lottery money. For Jefferson County, the figure was about $\$ 2.30$. For reasons to be explored presently, Crook County did not benefit from any of the lottery money allocated to fund Central Oregon's Regional Strategy. 
Earlier, it was argued that the prevalent position Deschutes County assumed in the Central Oregon Strategy was a function of the dominant role it played in the region's tourism sector and the capacity advantages enjoyed and instruments controlled by the Bend area's growth coalition. As a corollary, it appears that weak local capacity for administering economic development planning acted against Jefferson and Crook County's in efforts to secure funding under the aegis of the region's Strategy. As evidence of this, consider two strategy projects--one each in Jefferson and Crook County--that failed to come to fruition.

First is the large electronic reader board that was supposed to be installed in the Jefferson County seat of Madras along Highway 26, the principal highway connecting Central Oregon with metropolitan Portland. The sign would have announced area wide activities and local events to travelers, including ski conditions at Mount Bachelor. Initially funded to the tune of $\$ 35,000$, it accounted for 60 percent of Jefferson County's total lottery allocation and was Jefferson County's most prominent Strategy project. After the Strategy was adopted by the Governor, it was discovered that federal highway regulations prohibited construction of such a sign. Apparently, nobody had taken note of this. Consequently, the reader sign was never built and the lottery money allocated for it, never spent (Allen, January 25, 1990; EDD 1987). That officials in Jefferson County allowed themselves to be deprived in this manner is suggestive of a weak administrative capacity for economic development planning. Jefferson County's low capacity for economic development caused it to forego 60 percent of the lottery money it was initially allocated.

Next is the case of the Prineville Theater. This is the only Crook County project appearing on Table V. By all accounts, local officials expected renovation of the Prineville Theater to do little to expand tourism in Crook County. But the theater 
renovation was the only project submitted from Crook County, assuring it a place on the Strategy project list. Later, after the Strategy agreement had been ratified by the Governor, it was discovered that fire regulations required installation of an emergency exit on the side of the 50 year old theater building. No accounting had been made of the need for this exit. The abutting property owner refused to grant an easement for this exit. The Crook County Court, the County's governing body, demonstrated little inclination to condemn any of the abutting property. In any event, County finances were so constrained as to make this an implausible option anyway (Uffleman January 24, 1990; Comini January 24, 1990). The theater project was ultimately dropped and in the end, alone among the three Central Oregon counties, Crook County failed to avail itself of lottery money.

\section{Circumventing the Established Order}

Highway improvements were the centerpiece of Central Oregon's project list. Through Regional Strategies, local officials sought to secure improvements to the region's two main highways--Highway 26 , the principal route connecting Central Oregon with the Portland area and Highway 97, the region's principal north-south route. More so than any other project, the highway improvements were the product of regional consensus and promised to pay region-wide benefits. Securing improvement to Highways 26 and 97 had in fact long been a priority for the region, not only to tourism industry interests who believed that congestion impeded visitor travel but to others in the region as well. Recall the mentioning of highway improvements in the memorandum local officials sent to the Goldschmidt transition team in December, 1986. Consequently, seeing the highway improvements constructed emerged as a key Goldschmidt Administration goal. Governor Goldschmidt signalled this in his first 
meeting with the Group of Seven when, to recall, he voiced support for including highway improvements in Central Oregon's Strategy.

According to the December 3, 1986 edition of the Oregonian, at $\$ 17.5$ million, "the highway improvements would be more expensive than anything that is currently on the transportation drawing board for that stretch of road." Their cost also far exceeded the amount of lottery money Goldschmidt had allocated the three Central Oregon counties and indeed, equaled the entire sum lawmakers had appropriated for Regional Strategies, once funds committed to the Convention Center were removed. So it is clear that the highway improvements were not to be paid for with lottery money. Instead, highway improvement construction depended upon their being funded under the AOH (Access Oregon Highways) program, administered by the Oregon Department of Transportation (ODOT). AOH reserved surcharge state gas tax revenues for select state highway projects. Accordingly, the request for the highway improvements was inserted into the Central Oregon Strategy under that provision of HB 3011 which authorized counties to include in their Strategy lists request for "other forms of state assistance."

According to Mike Hollern, the Deschutes County developer who Goldschmidt appointed head of the Oregon Transportation Commission in January, 1987, including the improvements in the Central Oregon Regional Strategy was "essential to getting them done." As the Bend Bulletin (October 23, 1987) reported:

Hollern said if the Governor approves the Strategy, he will urge the Transportation Commission to make the projects a high priority. That could lead to some highway improvements as early as next year. Without the regional strategy, Hollern said, it might take eight to ten years for the commission to allocate funds for the project.

As it happened, Central Oregon did not have to wait ten years for its sought after highway improvements. They were scheduled for AOH funding under ODOT's 
six year improvement program and construction on some were begun in the following year. Hollern's role in this matter points to an important point, one made to the writer by Dale Allen (January 23, 1990), ODOT's administrator for Central Oregon. He told the writer in quite explicit terms that the success Central Oregon enjoyed with the highway improvements had little to do with Regional Strategies. Instead, asserted Allen, accelerated construction of the highway improvements was mainly attributable to the influence Hollern was able to personally exert as Transportation Commission head.

Recall from the previous chapter that Governor Goldschmidt was unsuccessful in extracting from the state legislature the extraordinary authority he sought over the Transportation Commission as well as other of the state's quasi-autonomous commissions. Subsequently, he tried another approach. Drawing upon his electoral mandate, he demanded the resignation of the entire Transportation Commission. He succeeded in securing the entire Commission's resignation, although not without some bitter recriminations. It was his success in this unconventional maneuver that allowed him to install Central Oregon's Mike Hollern, a key campaign supporter and principal force behind the construction of Central Oregon's highway improvements, as Transportation Commission chief.

The conditions surrounding construction of the highway improvements sheds light on the routines through which the Goldschmidt Administration secured its key industrial policy goals. Highway improvement construction had little to do with conventional channels of administrative authority. Instead, construction of the highway improvements was largely attributable to the Goldschmidt Administration's ability to resort to extraordinary, highly personalized routines outside the established order of public authority. 


\section{$\underline{\text { Subsidies }}$}

As with the highway improvements, the memorandum sent to Goldschmidt in December, 1986 had requested state assistance for building a Visitor Center in Bend. In fact, construction of the Visitor Center was paid for with $\$ 2$ million raised through a voter approved increase in the Deschutes County room tax. According to COED Director Peter Dobert (January 11, 1990), lottery money provided under the aegis of Regional Strategies was used only to install and furnish quarters within the Center to which as noted in the August 23, 1990 edition of the Bend Bulletin, COED, the Bend Chamber of Commerce, CORA, and other local agencies moved their offices. The Visitor Center, to paraphrase Dobert and others (Kozak January 24, 1990; Riggs January 25, 1990) would have been built "Regional Strategies or no Regional Strategies."

The Reservations Center, for which $\$ 65,000$ in lottery money was used to buy computer and affiliated equipment, was the project of Mount Bachelor, Inc., which committed $\$ 337,000$ to fund the its ongoing operations (EDD 1987). In fact, it appears that Mount Bachelor was prepared to appropriate funds for the Center prior to the advent of the regional development initiative (Kozak January 11, 1990). Having it included in the Central Oregon Strategy seems to have simply relieved the resort of two-thirds of the project's start-up costs.

Lottery money provided under Regional Strategies does not appear to have been instrumental in promoting capital investment which would have not otherwise occurred in either the case of the Visitor Center or Reservations Center. In both cases, the lottery money provided appears mainly to have comprised a subsidy, socializing the operational activities of certain quasi- public (COED, CORA) or wholly private agencies (the Chamber) and businesses (Mount Bachelor). 


\section{THE POLITICS OF ACCOMMODATION CONFIRMED}

The latter half of 1987 saw officials at the Oregon Economic Development Department striving to bring the Central Oregon Strategy to a close. As will be seen in the following chapters, EDD's efforts to bring the Strategy process to cloture extended beyond Central Oregon to other regions as well. EDD drove for closure in order to transform the various listed projects into reality. Only if these projects could be put quickly into effect might they demonstrate material results by early 1989 . It was evidence of progress in building or otherwise effecting listed projects that the Governor hoped to cite in efforts he would mount in seeking to reauthorize and refund Regional Strategies during the 1989 legislative session. In Central Oregon, however, there emerged an unexpected glitch which threatened to torpedo the whole Strategy effort.

Officials from areas expecting to derive little direct benefit from a tourism strategy had nonetheless accommodated themselves to one because they aimed to derive tangential benefits from doing so. In particular, they aimed to acquire state monies with which to augment ongoing industrial recruitment activities. The December, 1986, memorandum sent to Goldschmidt's transition team had, in fact, requested money for this purpose. A glitch in this arrangement arose in early September, 1987. Dick Reiten, recently appointed by Governor Goldschmidt to replace departed EDD Director Roger Smith, announced that Goldschmidt had decided to transfer $\$ 1.5$ million from the state's Community Development Block Grant (CDBG) fund for use in other of EDD's programs. In fact, two-thirds of the transferred CDBG money was destined to augment lottery monies available for funding Regional Strategies.

The officials seeking money for industrial recruitment apparently expected this money to be drawn from funds originally dedicated to the CDBG program. They read the 
decision to transfer the CDBG money as diminishing the amount of money that would be available for funding their industrial recruitment efforts and thus, abrogating the accommodation upon which their endorsement of a tourism strategy was based. Why else would Redmond Mayor Bob Riggs have responded to Reiten's announcement that the CDBG funds were being shifted by saying "We have to ascertain just what's proposed (by the state), how it is different from what we thought we were buying into and what's the appropriate response" (Bend Bulletin September 9, 1987). Riggs and fellow dissident officials saw themselves as having accommodated themselves to a tourism strategy from which they expected to gain little direct benefit. Now, with the cutback in CDBG funds, they saw themselves being penalized. The result was a rancorous challenge to the integrity of the Central Oregon Strategy agreement.

October 23, 1987, saw the Group of Seven meet to discuss the shifted CDBG funds. At the insistence of dissident officials, the region's project list was amended to include a request for an additional $\$ 200,000$ in lottery money for use in business recruitment. Notice of this decision was sent to EDD. The officials request was not to receive a favorable reception, however. Responding to the request, EDD official Bob Schumaker said "I don't think...Mr. Reiten is in favor of this proposal" Bend Bulletin November 13, 1987). And indeed, the request for the additional money was rejected. EDD's Dick Reiten (February 27, 1990) was asked about these events. Reiten responded that the decision to reject the appended Central Oregon request was, as with the decision to transfer the CDBG funds in the first place, made personally by Governor Goldschmidt. Reiten said that the Governor was opposed to direct grants of money to local governments for industrial recruitment purposes. In light of Reiten's comments, Goldschmidt's rejection of the appended Central Oregon request can be seen as evidence of both his seeming repudiation of industrial recruitment and his commitment to the 
implementation of multi-lateral strategies. In fact, the Goldschmidt Administration's actions in this matter had implications beyond Central Oregon. In rejecting Central Oregon's request for funds with which individual governments could conduct industrial recruitment, Goldschmidt sought to serve notice that similar requests made by other counties would also be refused. EDD official Bob Schumaker intimated this when, hinting that Central Oregon's request for the $\$ 200,000$ for industrial recruitment would be rejected, he called it a "test case" (Oregonian November 13, 1987).

The transfer of the CDBG funds into the pot of money available for Regional Strategies and concomitant curtailment of money available for local government industrial recruitment activities appears to have been consistent with the Goldschmidt Administration's goal of centralizing control over the state's economic development activities. This view was certainly shared by Madras Mayor Rick Allen, who upon learning of the CDBG funds transfer, remarked that the state was "trying to pull all the economic development money into Salem" (Bend Bulletin September 1O, 1987).

The Administration's refusal to countenance money for industrial recruitment vexed both Madras Mayor Allen and Redmond Mayor Bob Riggs, each of whom openly questioned the propriety of pursuing a tourism strategy. They were joined by officials from Crook County, with Dick Hoppes, head of the County Court remarking derisively "It's not a regional strategies plan, it's a Deschutes County plan that puts out little carrots to Crook and Jefferson counties if we go along with it." Hoppes also called the strategy a "Mickey Mouse document that shouldn't be adopted" (Bend Bulletin December 20, 1987). Amid this sort of rancor, Central Oregon's tourism strategy, hitherto the product of an albeit sometimes reluctant but nonetheless consensual accord, now threatened to unravel.

To get the Central Oregon Strategy back on track, officials from EDD met with their local counterparts. Negotiations produced an offer from the Goldschmidt 
Administration to make available, in lieu of the foregone CDBG money, an additional $\$ 215,000$ beyond what was originally requested in the region's project list to fund an industrial marketing campaign belatedly proposed by COED. COED aimed to use the money to add staff and purchase computer equipment for use in preparing materials for use in marketing the region to outside investors. According to officials from Jefferson and Crook Counties (Uffleman January 24, 1989; Comini January 24, 1989; Allen January 25,1989 ), some sort of unwritten agreement was also fashioned by which, should Regional Strategies be reauthorized for the 1989 biennium, the second Central Oregon Strategy would place greater emphasis upon directing lottery dollars to the outlying areas, instead of to Bend and its environs.

Dissident Central Oregon officials were not wholly satisfied with the terms of the Goldschmidt Administration's offer. Officials from Jefferson and Crook County appear to have viewed COED, headquartered in Bend, as having favored the Bend area in its activities to the detriment of their own communities. They clearly would have preferred direct benefit of industrial recruitment monies. Still, if only grudgingly, they acceded to the Administration's offer. They appear to have recognized few alternatives to doing so. The Administration remained adamant in its opposition to providing funding directly to the local governments for industrial recruitment purposes (Comini January 24, 1990; Uffleman January 24, 1990; Riggs January 25, 1990). Under these circumstances, they viewed the materials to be produced by COED, if not as a substitute for the industrial recruitment monies they had initially been seeking, contributing to their industrial recruiting efforts nonetheless. The dissidents were also swayed in their decision by the promise of future rewards in a second round of Strategy funding.

The offer to fund the COED project can be seen as something of a retreat for the Goldschmidt Administration from its opposition to industrial recruitment. Still, it was 
not a total retreat; granting the funding to COED instead of to individual local governments maintained a multilateral semblance in the Strategy. Also, by linking the agreement to a second round of Strategy funding, there was created in Central Oregon a constituency which could, in the same manner in which Governor Goldschmidt had initially employed his prototype, be used to lobby lawmakers into reauthorizing the program for the 1989 biennium. Agreement on the COED project paved the way for all three of the counties to hold final hearings on and adopt the Strategy, which was then sent to the Governor. He formally adopted the Strategy at a mid-January, 1988 ceremony at the state capitol in Salem.

\section{SUMMARY}

Central Oregon's multi-county tourism strategy was the product of an accommodation between the Goldschmidt Administration and local interests. At the local level, this accommodation was dominated by private- and public sector interests affiliated with a Bend area growth coalition. The instrument of their domination were the capacity advantages they enjoyed in planning and mobilizing for economic development. Objective economic analysis appears to have played little role in making policy decisions. Instead, policy choice appears to have been guided primarily by political considerations. Interests with a poor capacity for planning and mobilizing for economic development planning were placed in the subordinate position of accommodating themselves to a tourism strategy in the hope of deriving tangential benefits.

The Goldschmidt Administration's preference for implementing tourism strategies was founded upon the view of tourism as an industry with prospects for generating rapid employment growth. If a tourism strategy might generate rapid 
employment growth, however, it was likely to be job growth built upon a marginalized, low wage work force.

Success in securing Central Oregon's highest priority strategy project required that the Administration resort to highly personalized tactics in circumventing conventional channels of public authority. 


\section{NOTES}

1. Determining tourism related employment is an inexact science. Businesses serving tourists tend to be diffused throughout a number of industrial classes. To facilitate analysis in Table III, the writer has defined tourism in terms of employment of two U.S. Commerce Department industrial classifications groups likely more so than others to be tourist related--Food Service and Hotels and Lodging. Excluding other groups probably lends understatement while including the food service category [probably lends over statement. Still, the writer assumes that to the degree that overstatement or understatement occurs, it will be consistent.

2. One person who apparently advised Goldschmidt in this matter was Don Maziotti. He had served as a Goldschmidt aide during the latter's tenure as Portland mayor. Subsequently, he had worked in an economic development capacity for Pennsylvania Governor Dick Thornburgh. Mr. Maziotti may have played a role in shaping the Ben Franklin Partnership which, to recall, Osborne (1988) cited as the centerpiece of industrial policy in Pennsylvania. The writer sought to interview Mr. Maziotti. Unfortunately, he could not be contacted for interview.

3. As regards the analysis the writer undertook of tourism job generating prospects, several caveats are in order. First, due to an inability to contact those individuals who advised Goldschmidt of the propriety of tourism as an economic development strategy, it is unknown what data their findings might have been based upon. The data upon which Goldschmidt's advisers may have based their conclusions may well have differed with that employed here and therefore, supported different findings. Next, Goldschmidt's predilection for tourism was based upon its prospects for generating future job growth. Reliable data useful for projecting future job growth in the tourism sector were, however, unavailable. Therefore, the analysis offered here is based upon the assumption that the best predictor of future job generating performance is such performance in the recent past.

Also, Goldschmidt's predilection for tourism was based in part upon its prospects for driving job creation in other industries. The writer could find no reliable data of use in examining the link between tourism promotion or job growth in tourism sector and job growth in other economic sectors. There is no way of examining the credibility of this claim through data analysis and no attempt is made to do so. Instead, it is simply assumed that to the degree that tourism is likely to fuel job growth in exogenous sectors, this growth is likely to mirror that taking place in the tourism sector itself. Last, determining tourism related employment is an inexact science. Businesses serving tourists tend to be diffused throughout a number of industrial classes. Last, to facilitate this analysis, the writer defined tourism in terms of employment of two U.S. Commerce Department industrial classifications groups likely more so than others to be tourist related--Food Service and Hotels and Lodging. The qualifications presented above in footnote 2 are therefore pertinent here as well.

The limitations these caveats place upon this analysis are recognized. Given the scope of the present effort, however, these assumptions seem credible and this albeit imperfect analysis as likely to offer insight into the prospect that tourism might fit the definition of an emerging industry. 
4. There is a certain metaphorical dimension to the appearance of the two Dobert's before the Deschutes County Commission. They were in fact, married. Their marriage can be seen as a metaphor for the links that tied together COED and CORA and the key public and private actors that mobilized on behalf of a tourism Strategy in Central Oregon. 


\section{CHAPTER VII}

\section{IMPLEMENTING REGIONAL STRATEGIES IN SOUTHERN OREGON}

Planning for the Southern Oregon strategy involved six counties at one time or another. ${ }^{1}$ Only four were party to Southern Oregon's final strategy accord-Jackson, Josephine, Douglas and Curry Counties. These four are incorporated into the depiction of Southern Oregon offered in Figure I. The two others involved in planning the Southern Oregon Strategy but not party to its final product--Klamath and Lake Counties--are excluded from this depiction.

Implementation of Southern Oregon's Regional Strategy saw the Goldschmidt Administration override local preferences to impose a multi-county tourism strategy upon a region divided by centrifugal forces and possessing a weak capacity for economic development planning. Southern Oregon's Strategy points to the Sunset and no-seconds clauses as legislatively-enforced limitations upon gubernatorial success. The Administration proved able to use the Regional Strategies arrangement to secure goals in circumstances in which goal attainment was contingent upon lottery money under the Administration's control. Regional Strategies proved less efficacious when goal attainment was contingent upon the cooperation of semiautonomous elements of the state apparatus. The failure of private capitalists to make expected investments in a key strategy project points again to the character of private investment as a limitation upon the state to use industrial policy to promote economic development. 


\section{BALKANIZATION IN OREGON}

February, 1987 saw Governor Goldschmidt call representatives from three Southern Oregon counties to meet with him in Salem. He used the meeting to ask the officials to join together in developing a collective three county Southern Oregon Regional Strategy, one to which neighboring counties might also be linked. The period leading up to 1987 was one of widespread economic distress throughout Southern Oregon. The aggregate unemployment rate for the three counties represented at the February meeting--Jackson, Josephine, and Klamath--reached over 16 percent during the winter of 1981-82. Klamath County's unemployment rate went over 20 percent. All three counties were included among the twenty-six Oregon counties designated by the U.S. Labor Department as labor surplus areas in November, 1985. Local government revenues were significantly curtailed. Josephine County's general fund revenues declined especially precipitously, from $\$ 17.2$ million to $\$ 12.7$ million between 1979 and 1984, a drop of over 25 percent (Oregonian January 1, 1986).

Unsurprisingly, given this state of affairs, the local officials agreed to take part in Governor Goldschmidt's economic development initiative. But they resisted committing themselves to collaboration on a collective strategy, at least in the initial stages of strategy development. Instead, they wanted each county to be responsible for identifying its own strategy. They would then see if the individual strategies could be merged into one (Blake January 8, 1990; McGregor February 8, 1990; Reyneke February 8, 1991). Jane Reyneke, Mayor of Grants Pass, Josephine County's largest city and an attendee at the February meeting at which Goldschmidt moved to inaugurate planning for the Southern Oregon strategy reiterated her reluctance to engage in multi-county strategy 
planning in the March 22, 1987 edition of the Medford Mail, Southern Oregon's largest local newspaper. She said it was "premature to talk about regionalization" of Regional Strategies. Jackson County Commissioner Stuart McCullom expressed a similar view, being quoted in the same newspaper as saying that "Regionalization is not going to come easy."

\section{The Roots of Regional Divisiveness}

In part at least, it may have been because Klamath County's representative at the meeting with Goldschmidt, Dr. Larry Blake, was a key player in efforts to promote construction of a power dam on the Klamath River. As shall be seen in the following chapter, Blake sought to use Regional Strategies to promote the dam's construction. Blake saw tying Klamath County to a multi-county collaborative as incompatible with this goal. Still, it is clear that Southern Oregon lacked a strong tradition of the sort of multi-lateral collaboration proposed by Governor Goldschmidt. Elazar (1972:97) depicts Southern Oregon as being infused with strains of an individualistic political culture. Atomism and insularity are key traits of the individualistic culture, traits prone to disparage exogenous dependencies and unlikely to foster multi-lateral cooperation.

Economic development was a particular source of inter-communal antagonism in Southern Oregon. There were at least two sources of these antagonisms. The first pertains to the relative equiponderance that characterized the region's spatial structure. The second pertains to the diversity that characterized the region's industrial structure. One way to make this point is to compare Southern Oregon to Central Oregon. Southern Oregon was much more populous, more economically diversified and characterized by less primacy than Central Oregon. 
In 1986 , the total population of the three county Central Oregon region was 90,000 . With a municipal population of over 18,000 , the city of Bend accounted for over 20 percent of the region's total population. None of Central Oregon's six other incorporated communities contained as many as 7,000 people. With surrounding unincorporated areas included, the Bend vicinity accounted for 40 percent of Central Oregon's total population. With 256,550 people living in Jackson, Josephine, and Klamath Counties at the time Goldschmidt moved to inaugurate Regional Strategies, Southern Oregon was much more populous than Central Oregon. With a population of 43,875 , the city of Medford was the largest municipality in the three county Southern Oregon area. Still, Medford accounted for only 15.6 percent of the three county region's population. There were seventeen other incorporated communities in the three county area however including three with municipal populations almost equalling that of Bend alone: Klamath Falls $(17,030)$, Grants Pass $(16,200)$, and Ashland $(16,010)$. Furthermore, unlike Bend, ringed only by unincorporated communities, Medford was surrounded by several incorporated cities. In terms of urban structure, there was much more parity in Southern Oregon than in Central Oregon, where Bend asserted a high degree of primacy.

As regards the diversity that characterized Southern Oregon's industrial structure, in 1986, total wage and salary employment in the three Counties represented at the February meeting at which Governor Goldschmidt moved to inaugurate a Southern Oregon Regional Strategy was 62,101; the comparable figure for Central Oregon was 27,059 (Employment Division 1986). All three Southern Oregon counties were heavily dependent upon wood products manufacturing; it accounted for 15.4 percent of total wage and salary employment in the region in 1986. Still, wood products played less of a role in the Southern Oregon region than in Central Oregon 
(20.9 percent). Whereas wood products accounted for 77 percent of Central Oregon's manufacturing sector employment, it accounted for only 65 percent of manufacturing sector employment in Southern Oregon. Electronic equipment and instruments, paper products, transportation equipment, and fabricated metal products all played significantly more important roles in Southern Oregon's manufacturing sector than in Central Oregon's. Trade, both wholesale and retail, accounted for a significantly larger share of total employment in Southern Oregon than in Central Oregon. Transportation, including warehousing, health care and education also accounted for a larger share of total employment in Southern Oregon than in Central Oregon. At 10.3 percent, the share of Southern Oregon employment accounted for by tourism was below that of Central Oregon. The point here is that Southern Oregon's economy was more diversified and balanced than that of Central Oregon.

The multi-polarity, both spatial and industrial, that characterized Southern Oregon created conditions ripe for discord as place economies and industrial interests pursued their own distinctive aims. One sign of these antagonism: the city of Grants Pass, Josephine County's largest city and county seat, has twice joined and then withdrawn from the Rogue Valley Council of Governments, the region's COG (Reyneke February 8, 1990; Shaff February 7, 1990). A particular point of contention during the period in which the Goldschmidt Administration moved to inaugurate planning for Regional Strategies was the siting of a pulp mill by a company named Westbrook Wood Products. The mill was heavily recruited by officials from both Medford and Klamath Falls. This not only strained relations between these two communities. It also strained relations between officials from Medford and their counterparts from the city of Ashland, located about twelve miles to the south. Jackson County suffered from serious air pollution problems, which officials from 
Ashland, heavily dependent upon tourism-related activities, feared the new pulp mill would exacerbate. Fearing more pollution would deter visitors, officials from the Ashland Downtown Merchants Association and Ashland Visitors and Convention Bureau joined with environmentalists in opposing locating the Westbrook pulp facility in Medford (Keller January 8, 1990; Golden February 5, 1990; Leister February 6, 1990). In the event, Westbrook Wood Products decided against locating its pulp mill in either Jackson or Klamath Counties.

\section{Weak Planning Capacity}

The elements of Southern Oregon's economic development apparatus were highly fragmented and prone to conflict with each other. The Medford Mail Tribune sought to make this point when it reported in its March 24, 1987 edition that in early 1987, there were in Jackson and Josephine Counties alone over 25 separate organizations engaged in some sort of economic development activity. According to the newspaper, these groups were highly fragmented along sector and territorial lines and worked at "cross purposes." Again here, some comparison to Central Oregon is instructive. Central Oregon possessed a relatively cohesive and capable economic development apparatus. This stands in stark contrast to Southern Oregon, a region characterized by divisiveness and possessing a highly fragmented and relatively incapable economic development apparatus.

The Jackson County Economic Development Association (JCEDC) was probably the most important economic development agency in Jackson County in 1987. It's counterpart in Josephine County was the Josephine County Economic Development Council (JEDA). Both were private, non-profit corporations jointly funded by county and municipal governments and local businesses. In effect, JCEDC and JEDA acted as the economic development arms of their constituent county and 
city governments. Neither JCEDC nor JEDA appears to have been particularly effective, however. The March 24, 1987 edition of the Medford Mail Tribune reported that JCEDC had an "unstable past." The same edition quoted Bob O'Niel, former JCEDC Executive Director, as saying that local economic development efforts were in a state of "chaos" and that JCEDC and JEDA "would be hard pressed to say they've recruited directly, more than 25 jobs" to the region. According to the newspaper, despite "public fund expenditures in the tens of thousands of dollars," local economic development efforts had "produced only a few new employers providing only a handful of new jobs."

The first half of the 1980s had seen several attempts aimed at joining Jackson and Josephine counties in a bi-county economic development district. JEDA and JCEDC were envisaged as the core of this new entity. The aim was to boost Southern Oregon's capacity for economic development by creating an organization eligible for U.S. Department of Commerce economic planning assistance, which the individual economic development organizations were ineligible for. Progress proved slow, being impeded by conflicts among local officials over where the new agency would be located and how and by who it would be staffed and led. In consequences, no such district had yet been formed by the time Goldschmidt moved to inaugurate the Southern Oregon Strategy (Mail Tribune March 24, 1987; August 14, 87; Reyneke February 8, 1990; Golden February 5, 1990).

\section{THE DEMOCRATIZATION OF STRATEGY SELECTION}

Efforts in Josephine and Jackson Counties to identify a Regional Strategy produced somewhat different outcomes. Both cases stand in stark contrast to Central Oregon, however. For unlike Central Oregon, where implementation of Regional 
Strategies was captured by a powerful Bend area growth coalition, in Josephine and Jackson Counties, local efforts to identify a Regional Strategy were characterized by broad based and widespread participation.

\section{Inertia in Josephine County}

Jane Reyneke was one of the local officials present at the February, 1987 meeting at which Governor Goldschmidt moved to inaugurate planning for the Southern Oregon Regional Strategy. The Mayor of Grants Pass, Josephine County's largest city and county seat, she was a political ally of the Governor's, having gone as far as to switch her party affiliation, from Republican to Democrat, in order to endorse him in his bid for the Governor's office (Mail Tribune June 23, 1987). Goldschmidt did not fare well in Josephine County vote--he won only 44 percent of the County's gubernatorial vote (Secretary of State 1987-88). Nonetheless, he rewarded Reyneke, first with an appointment to his transition team and later, with an appointment to the state Board of Education. In moving to inaugurate planning for Josephine County's Regional Strategy, Governor Goldschmidt called upon the assistance of political loyalists who could be depended upon to adhere to his policy preferences. 2

Shortly after the February, 1987 meeting at which Governor Goldschmidt moved to inaugurate the Southern Oregon Regional Strategy, Mayor Reyneke met with the Josephine County Board of County Commissioners. As an outcome of their deliberations, a six person steering committee was established, its purpose to select a target industry for Josephine County. The decision to form a steering Committee is perhaps best explained as a function of risk aversion. According to Commission Chairman Bruce McGregor (February 8, 1990), the County Commissioners were themselves reluctant to incur direct responsibility for overseeing the strategy process, a reluctance born of the novelty of the Regional Strategies arrangement. The 
commissioners saw the Regional Strategies process as bearing little semblance to the type of industrial recruiting schemes with which the they had traditionally been accustomed. They also viewed the task of selecting a Regional Strategy as a potentially divisive process which might embroil them in controversy. By delegating responsibility for overseeing the strategy process to the Steering Committee, the Commissioners sought relief from a risk-prone responsibility they were themselves reluctant to accept.

Mayor Reyneke assumed the position of Chair-person of the Committee. The Committee's other members were Bruce McGregor, Chairman of the Josephine County Board of County Commissioners; Art Jackson, a local businessman and President of JEDA, the Josephine County Economic Development Association; Claudell King, a local realtor and President of the Grants Pass Chamber of Commerce; Dr. Harvey Bennett, President of the Rogue Valley Community College, located in Grants Pass; and Joe Kauzlarich, head of the Grants Pass regional office of the Pacific Power and Light Company. During March, 1987, the Committee held what the Medford Mail Tribune (March 22, 1987) described as "a series of town hall type meetings in Grants Pass." They were widely advertised and by all accounts, well attended; a roster of participants listed over 75 names (Steering Committee 1987). The Committee's meetings appear to have opened the strategy process to a range of local interests. Perhaps the best evidence of this is the three options that, as an outcome of the workshops, the Steering Committee agreed to consider as candidate target industries: tourism, retirement services, and secondary wood products. Each had its supporters in the local polity. None of the three, however, could muster the level of local support necessary to being selected as Josephine County's Strategy. 
Tourism: The Exogenous Strategy Grants Pass Mayor Jane Reyneke was a leading proponent of implementing a tourism strategy in Josephine County. She evinced her enthusiasm for a tourism in something of a prescient manner. Interviewed in late March, 1987, before the Steering Committee had concluded its public outreach effort, she was asked how she thought the strategy selection process would turn out. The Mail Tribune (March 22, 1987) reported "Reyneke says she is certain what Josephine County's choice will be." According to the newspaper, Reyneke said, "It [the strategy] will surely come out tourism." Seen within the context of Mayor Reyneke's relationship with Governor Goldschmidt, it is difficult to avoid the conclusion that in endorsing a tourism strategy, Mayor Reyneke was taking her cue from the Governor.

Tourism was not an inconsequential industry in Josephine County. As Table VI shows, in 1985, the year closest to 1987 for which figures were available, travel expenditures in Josephine County totalled just under \$35 million, ranking Josephine County fifteenth among Oregon's thirty-six counties in this category. Taken together, total travel expenditures for Jackson, Josephine, and Klamath counties exceeded the total for the three county Central Oregon region by almost 35 percent. Still, there is a critical difference to be noted between the structure of Central Oregon's and Southern Oregon's tourism sectors. In contrast, visitors are most attracted to Southern Oregon by publicly owned natural areas, especially Crater Lake National Park, the Oregon Caves National Monument and the Rogue River, a favorite spot for rafting enthusiasts, or periodic artistic events, the principal example being Ashland's Shakespeare Festival, the annual summer long schedule of theater. The effect has been to define Southern Oregon's tourism sector primarily in terms of small, territorially diffuse business enterprises--restaurants, lodging establishments, retail shops, gas stations, 
SHARE OF TOTAL EMPLOYMENT IN TOURISM,

TOTAL TRAVEL EXPENDITURES AND TRAVEL

GENERATED PAYROLL PER-CAPITA

IN SOUTHERN OREGON

\section{\% SHARE OF TOTAL \\ EMPLOYMENT IN \\ TOURISM 1986}

Southem Oregon
Jackson County
Josephine County
Klamath County

Centrat

Deschutes County

Oregon

\section{$10.3 \%$}

$10.3 \%$

$11.2 \%$

$9.7 \%$

$11.2 \%$

$12.4 \%$

$9.6 \%$

\author{
TOTAL 1985 \\ TRAVEL \\ EXPENDITURES
}

$\$ 205.350$

$\$ 113,246$

$\$ 35,939$

$\$ 56,165$

$\$ 152,875$

$\$ 140,672$

$\$ 2,519,797$
TRAVEL GENERATED

PAYROLL

PER-CAPITA 1985

$\$ 165$

$\$ 172$

$\$ 116$

$\$ 199$

$\$ 333$

$\$ 445$

$\$ 199$

Notes:

Source of employment data: U.S. Census Bureau, County Business Pattems

Tourism employment defined as SIC 58 (Eating and Drinking Places) and SIC 70 (Hotel and Lodging Places)

Source of payroll data: Oregon Economic Development Department, nd. 
and outdoor outfitters There was little in Southern Oregon akin to Mount Bachelor and the other high-value added, territorially concentrated privately owned visitor facilities affiliated with the Bend area in Deschutes County.

Figures on travel generated payroll per-capita--total travel payroll divided by population--help convey the essential differences between tourism in Southern Oregon and Central Oregon. In 1985, Central Oregon's tourism sector generated \$333 in payroll for each resident of the three county area, a figure 67 percent above the statewide average. For Southern Oregon's more pedestrian tourism sector, the comparable figure was only $\$ 165$. For Josephine County, perhaps the least tourism intensive of the Southern Oregon counties, the figure was only $\$ 116$, a mere 58 percent of the statewide average.

Southern Oregon's tourism sector was territorially diffuse, fragmented and composed of low value added enterprises, characteristics unlikely to give rise to strong industrial elites and a strong sense of industrial cohesion. Indeed, neither Josephine County or for that matter, the greater Southern Oregon region evinced the sort of concerted and organized mobilization by business elites that characterized the Central Oregon Strategy. There existed nothing in Josephine County akin to CORA, the Central Oregon Recreation Association nor did a local newspaper with strong business connections forcefully endorse a tourism strategy, again as in the case of the Bend Bulletin. It was not, in contrast to Central Oregon, a function of locally mobilized interests. Tourism related businesses played only a subordinate role in lobbying on behalf of a tourism strategy in Josephine County. More so than anything, the impulse to Josephine County's consideration of tourism as a Regional Strategy appears to have been exogenous, being attributable to the role Goldschmidt ally Mayor Jane Reyneke played in the strategy selection process. 
Retirement Services: The Endogenous Strategy Drawn by affordable housing costs and the area's environmental and recreational amenities, Josephine County experienced a large influx of retirees during the 1970s. The influx continued through the first half of the 1980s, when a failing local economy led many of working age to leave in search of work elsewhere. Seniors emerged as the fastest growing component of Josephine County's population, with those age 65 and over increasing their numbers by 28 percent between 1980 and 1986. By 1985, 17.6 percent of the County's population was age 65 or older. The comparable figure for Oregon as a whole was 13 percent, 11.9 percent for the nation as a whole. The influx of retirees appears to be the principal reason why Josephine County was one of only four Oregon counties that experienced a net population increase between 1980 and 1986 (Center for Population Research and Census nd).

As their share of the population increased, the retirees, whose propensity for voting out of proportion to their numbers is well established, became a force in local politics. By Jane Reyneke's (February 8, 1990) own admission, her election as mayor could be seen as an expression of the political influence of Josephine County's retirees; the former schoolteacher admitted to having been elected largely on the basis of strong support from the area's senior citizens. Claudell King (February 6, 1990), the realtor who headed the Grants Pass Chamber of Commerce, depicted her election as Mayor as a repudiation of the business-centered power structure that had traditionally governed the city in the period leading up the 1980s. In the Steering Committees meetings, the retirees weighted in by placing retirement services on the County's strategy agenda (Kauzlarich February 6, 1990; King February 6, 1990; McGregor February 8, 1990; Bradbeer February 8, 1990; Clark February 7, 1990). By 
retirement services, backers meant using Strategy money to enhance facilities serving Josephine County's large retirement community.

If Josephine County's retirement community placed retirement services on the County's Regional Strategies agenda, it's important to note that the support for a retirement services strategy among this important element of Josephine County's polity was not monolithic. Take the case of Mayor Reyneke, the retired school teacher whose election was largely attributable to the votes of the retirees. The extent of her commitment to a tourism strategy needs little elaboration. According to Michael Clark of Senior Views (February 7, 1990), an seniors' advocacy organization, Mayor Reyneke actively sought to enlist retiree support for a tourism strategy and that her efforts were, in many cases, favorably received. Mr. Clark cited two factors in explaining the basis of tourism's appeal to the retirees. First, many of the retirees had moved to Josephine County to take advantage of the area's natural and recreational amenities. The retiree community appears to have been attracted to a tourism strategy because they viewed the projects likely to arise from a tourism strategy as likely to enhance these amenities. Second, the retirees appear to have cast tourism as a prospectively unobtrusive strategy, one dependent upon transitory visitors unlikely to burden the them with increased public service costs.

Secondary Wood Products: The Establishment Strategy Josephine County's Steering Committee also came to consider secondary wood products as a strategy option. Secondary wood products referred to the fabrication of products ranging from industrial pallets to structural housing members to window moldings, doors, and furniture. The position secondary wood products came to occupy in the Steering Committee's deliberations was an outgrowth of a 1986 target industry study conducted by the Pacific Power and Light Company. The study concluded that 
promoting development of a secondary wood products sector could help add value to the primary wood stock products turned out by local mills (Pacific Power and Light Company 1986).

Among the three Strategy options, secondary wood products appears to have been the one most favored by Josephine County's traditional business establishment. It was favored, for example, by Joe Kauzlarich (February 6, 1990), the PP\&L official who sat on the Steering Committee, perhaps unsurprisingly given the origins of this strategy idea, and Claudell King (February 6, 1990), the Chamber of Commerce President who sat on the Steering Committee as well as by JEDA's Steering Committee representative, Art Jackson. Corky Leister (February 6, 1990), JEDA's Executive Director, explained why secondary wood products was popular with Josephine County's business establishment. It saw secondary wood products strategy as consistent with the area's long mill working tradition. Leister made this point himself when he testified at a hearing the Josephine County Commissioners held in October, 1987. Testifying on behalf of a secondary wood products strategy, Leister argued that with "no port, research facilities, or major population center, [Josephine County] doesn't have any innate attraction for other industry". (Mail Tribune October 28, 1987). If Josephine County's business establishment favored secondary wood products, however, is seems to have lacked the capacity to transform its policy preferences into authoritative decisions. Claudell King, the Grants pass realtor and Chamber of Commerce head sought to make this point when he described a local business establishment whose traditional role as a leader in local affairs had been eroded by decline in the mill sector, its inability to resuscitate the local economy battered by six years of recession through traditional means and changed 
demographics, specifically the infusion of retirees. King pointed to the election of Mayor Reyneke as one sign of diminished business sector influence. ${ }^{3}$

Indecision When interviewed, Bruce McGregor (February 8, 1990), the Josephine County Board of Commissioners Chairman and Steering Committee member described the Committee's deliberations as having comprised an exercise in finding "something everyone could agree on." The Committee's deliberations were universally depicted as a wholly political exercise aimed at reconciling the aims of the various strategy option proponents. But with a polity divided over strategy choice, weak technical capacity for economic development planning, a business establishment whose capacity for leadership had been badly eroded and, Mayor Reyneke aside, a political leadership reluctant to assume a leadership position, cloture proved evasive. The Klamath Falls Herald and News made this point in its September 18, 1987 edition when it reported, fully six months after strategy selection began, that "Josephine County has not selected a prime topic but is investigating retirement, secondary wood products and tourism as strategies." Josephine County would not finally resolve its efforts to select a Regional Strategy until November, 1987, a full eight months after it had initiated its strategy effort, and only after Governor Goldschmidt had issues a threat to veto any Strategy in Southern Oregon that did not stress tourism, as shall be seen.

\section{Jackson County: Strategy by Consensus}

Jackson County shares many similarities with Josephine County. The two counties share the Rogue River Valley. Like Josephine County, Jackson County was one of only four Oregon counties to experience net population increase between 1980 and 1986. Most of the Jackson County's population growth during this period was, as in Josephine County, attributable to retirees. Between 1980 and 1986, the number of 
Jackson County residents age 65 or over expanded to 20,720 from 7,168, an increase of 189 percent. This compares to an overall addition to the County's population of 5,944 during this period, equivalent to an increase of 4.5 percent. At 14.9 percent, the share of Jackson County's population age 65 and older in 1985 was above the comparable figures for both the state (13\%) and nation (11.9\%) as a whole, if below the Josephine County figure (17.6\%) (Center for Population Research and Census nd). As in Josephine County, the demographic changes experienced by Jackson County in the period leading up to 1987 were described as having contributed to a realignment in local politics (Shelby February 5, 1990; Ford February 6, 1990; Shaff February 7, 1990). One sign was the election of Jeff Golden to the Jackson County Board of County Commissioners. The Harvard educated environmentalist and former Ashland City Councilman was elected to the County Commission with strong senior citizen support in the same November, 1986 election that installed Neil Goldschmidt as Oregon's Governor. Golden's election was described as having shaken up a County Commission long dominated by minions of the region's timber interests. As with Josephine County, the Jackson County's economy has traditionally been rooted in logging and mill working. Wood products remained the largest single employer in Jackson County in 1987. Still, wood products accounted for a significantly smaller share of total County employment than in Josephine County. The former was in fact significantly more economically diversified than the latter (Oregon Employment Division 1987). Trade, the manufacturing of transportation equipment, particularly boats and prefabricated housing, business and financial services, and warehousing and transportation all played significantly larger roles in Jackson County than in Josephine County. So did the cultivation of vegetables and fruits, which provided stock for the County's young but growing 
vintner industry. Education also played a significant role in the Jackson County economy; Ashland was home to the four year Southern Oregon State College. Tourism was also important in Jackson County. The County ranked eighth among Oregon's thirty-six counties in terms of total travel expenditures in 1985 (EDD 1985). According to the Medford/Jackson County Visitors and Convention Bureau, Jackson County's most popular visitor attraction was Crater Lake National Park. Actually, the park is situated not in Jackson County but within neighboring Klamath County. However, Jackson County offers the principal entrance to the Park from Interstate-5, the west coast's main north-south highway corridor, leading the Medford/Jackson County Visitors and Convention Bureau to herald the County as the "Gateway" to Crater Lake. As in Josephine County, Jackson County's tourism industry was composed primarily of small, low value added, territorially diffused establishments. Table VI help make this point. At $\$ 172$, Jackson County's travel generated payroll per-capita was, while greater than the figure for Josephine County, lower than the statewide average and, instructively, only 39 percent of the Deschutes County figure. There was something of a concentrated component to Jackson County's tourism sector revolving around Ashland's Shakespeare Festival, the summer-long theater event. But this was a seasonal event falling far short of the high value added, capital intensive attractions associated with the Bend area.

Jackson County was larger than Josephine County. Home to almost 140,000 in 1987, Jackson County was over twice as populous as Josephine County, with just under 62,000 residents. Jackson County's population was also much more territorially and jurisdictionally diffuse than Josephine County's. In 1987, there were eleven incorporated communities in Jackson County. Medford, the largest with 44,000 residents, accounted for about for about 31 percent of Jackson County's total 
population and was home to 2.7 times as many people as Ashland, Jackson County's next most populous city. In contrast, Josephine County contained only two incorporated communities. At 16,200 , the population of Grants Pass, the county seat, exceeded the population of Cave Junction $(1,175)$, located to the west, by almost 13 times (Center for Population Research and Census 1988). These differences may explain the somewhat different outcome that emerged from a strategy identification effort in Jackson County that was otherwise not markedly different from that undertaken in Josephine County.

Access and Participation Planning for implementation of Regional Strategies in Jackson County began with the February, 1987 meeting hosted in Salem by Governor Goldschmidt. Representing Jackson County at the meeting was Lynn Newbry. A senior Vice-President of the Medford Corporation, one of Southern Oregon's largest wood products concerns and President of JCEDC, the Jackson County Economic Development Council, Newbry was a highly respected leader of Jackson County's business community. He was also a longtime Republican party loyalist and former Republican state legislator who had headed Vic Atiyeh's successful 1979 gubernatorial campaign and subsequently, served as Governor Atiyeh's first Executive Department Director. Yet, Oregon's 1987 gubernatorial election saw Newbry depart from his traditional Republican allegiance and endorse Democratic gubernatorial candidate Neil Goldschmidt (Oregonian September 16, 1986).

Returning to Medford from the meeting at which Governor Goldschmidt moved to inaugurate Southern Oregon's Regional Strategy, Mr. Newbry met with the Jackson County Board of County Commissioners. Subsequently, a decision was made to appoint a twelve member body and make it responsible for overseeing selection of 
Jackson County's target industry. This body ultimately came to be known as the Jackson County Regional Economic Development Technical Advisory Committee (TAC). At the time Governor Goldschmidt moved to initiate planning for Southern Oregon's Regional Strategies, primary responsibility for local economic development activities in Jackson County lay with JCEDC, the local economic development council. Acknowledging this, the Jackson County Commissioners asked JCEDC, of which Newbry was President, to oversee the Strategy effort. According to Liz Shelby (February 5, 1990), the JCEDC Executive Director at the time who therefore worked closely with Newbry, the decision to appoint the TAC was a product of bitter controversy which ranged over efforts to recruit a pulp mill to Medford. This was the Westbrook Wood Products mill described earlier. JCEDC's efforts to recruit the mill to Medford had evoked opposition from several quarters, most notably among the area's tourism related interests, environmentalist constituency and, unsurprisingly perhaps, senior citizens who, due to their age, were especially prone to respiratory disease (Shaff February 7, 1990). According to Shelby, JCEDC President Newbry seized upon appointment of a broadly representative TAC as a means of offering pulp mill critics an interest in local economic development planning activities and in doing so, perhaps defusing, diverting, or otherwise expunging their criticism of JCEDC's role in the pulp mill controversy.

The TAC held its first meeting in April, 1987. The twelve member panel included representatives from a broad spectrum of Jackson County's polity. Instead of having but a single chair-person, the TAC had two co-chairs. According to the September 27, 1987 edition of the Mail Tribune, the TAC convened "more than 60 meetings in communities throughout the county and put in more than 1,000 hours of work." The TAC meetings appear to have been well attended and offered widespread 
access to the strategy selection process and to have opened up the County's Strategy deliberations to a broad range of participants. One indicator of this is suggested in the diversity that characterized the list of potential strategies considered by the TAC. These ranged from promoting tourism, small business development, retirement services and air-shed improvement to secondary wood products manufacturing, enhancing the area's educational facilities and helping to develop the area's wine industry.

The Festival Proposal: The Status Quo Embellished The TAC released its Strategy proposal in September, 1987. Entitled "Jackson County-A Festival Strategy: A Regional Strategy For the Oregon Comeback With Events, Products, and People," the proposal can best be described as a plan for organizing a series of symposiums to be held in conjunction with some of the artistic and industrial trade festivals hosted each year in Jackson County. The proposal was largely devoid of specifics; its architects envisaged it as a blueprint, to be defined further. To lend some sense of how the Festival arrangement might work in practice, an example was provided. This example cited the symposium officials at Southern Oregon State College, located in Ashland, had organized in conjunction with the preceding year's Shakespeare Festival. The symposium is reputed to have attracted teachers and scholars from around the nation to Jackson County. By organizing other festival/symposiums along similar lines--a symposium on viniculture research and development in conjunction with the County's Wine Festivals, to cite another example contained in the proposal--the TAC envisioned the Festival Strategy as a vehicle for show casing the area to visitors, perhaps attracting investment and entrepreneurial talent to Jackson County.

Two features of the Festival proposal are particularly instructive. First, the clear intent of the Festival proposal architects was to avoid favoring any particular 
faction of Josephine County's polity. The TAC acknowledged this in the Festival proposal, writing:

Five sectors of the economy--agriculture, education/human development, health care/retirement, timber/wood products, tourism, and manufacturing--are of equal importance to the health and vitality of Jackson County. The TÂC believes all should be given equal consideration in the economic development strategy under the unifying Festivals theme (Technical Advisory Committee 1987).

In concluding that there were five sectors of equal importance to the Jackson County economy, the TAC appears to have consulted information from a variety of sources in its deliberations. Included were economic and industrial statistics provided by EDD, the state Employment Division, Portland State University's Center for Population Research and Census and the U.S. Census Bureau (Wehinger February 6, 1990; Densmore February 7, 1990). Still it is clear that the TAC's strategy decision had less to do with empirical analysis than with the need to reach consensus amongst the diverse interests involved in the strategy process. For as the TAC itself essentially admitted, in choosing to target five economic sectors, the TAC essentially aimed to perpetuate, through the Festival proposal, Jackson County's existing industrial structure. Given the difficulties that had beset Jackson County's economy in the period leading up to 1987 , maintenance of the status quo was an unlikely avenue to economic renewal.

As regards the Festival proposal, the second important feature was the TAC's acknowledgement of Governor Goldschmidt's predilection for tourism Strategies. In fact, the TAC viewed the Festival proposal as consistent with the Governor's preference, so much so that the November 3, 1987 edition of the Medford Mail Tribune reported that its backers had come to refer to it as "Jackson--A Festival County, A Tourism Plus Strategy for the Oregon Comeback." Nonetheless, the proposal's architects did no aim solely to target tourism as the County's target 
industry. This came out in comments made by Patti Bills, Director of the Medford/Jackson County Visitors and Convention Bureau and reported in the same November Mail Tribune edition. Characterized in the newspaper as "One of the County's prominent tourism promoters," Bills complained that she had been "the lone voice" in calling upon the TAC to make an explicit commitment to pursuing a tourism promotion strategy, which the TAC had declined to do.

\section{OVERRIDING LOCAL PREFERENCES}

September, 1987 found Josephine County still undecided on exactly what its strategy would be. Jackson County was "fairly well set on festivals and designation of the county as Oregon's festival county" (Herald and News September 18, 1987). Curry County occupies Oregon's southwestern-most corner, between Josephine County and the Pacific Ocean. The September 18, 1987 edition of the Herald and News reported that Curry County had selected "Fish Enhancement as its top economic development strategy." As a practical matter, this amounted to a plan to use lottery dollars to renovate docks that had fallen into disrepair in Brookings, the County's largest town.

\section{Carrot and Stick Tactics}

The latter half of 1987 saw the Goldschmidt Administration make it increasingly clear that it would countenance no strategy in Southern Oregon that did not embrace tourism as its focus. So unmistakable was this message that the November 4, 1987 edition of the Medford Mail Tribune reported that it was "evident" that any Southern Oregon Strategy that did not target tourism "would be doomed." Commensurate with its edict that the Southern Oregon counties adopt tourism strategies, the Goldschmidt Administration made it clear that it intended to see the 
Southern Oregon counties implement their tourism strategies through a common multi-county Strategy block. Again, this message was unmistakable, as the November 4, 1987 edition of the Mail Tribune again made clear. The newspaper reported that:

Goldschmidt and state Economic Development Department officials have made it clear that they will look most favorably on larger, multi-county regions in deciding on the eventual disbursement of Lottery revenues.

Also, the last quarter of 1987 saw Goldschmidt Administration officials exert increasing pressure upon the Southern Oregon counties to accede to a multi-county tourism format as expeditiously as possible. Lise Glancy, the EDD staffer responsible for overseeing the Southern Oregon Strategy made this point when she was quoted in the October 23, 1987 edition of the Medford Mail as saying "There comes a point where participants in the process want to come to closure." The upshot of these circumstances was the decision, reported in the December 20,1987, edition of the Oregonian, that the Southern Oregon counties had "agreed to work as one in developing a regional tourism development strategy."

The decision by the Southern Oregon counties to acceded to a multi-county tourism strategy was uniformly attributed to the "carrot and stick" tactics employed by the Goldschmidt Administration. Perhaps nobody offered a better explanation of why the Southern Oregon counties agreed to join together in implementing a common tourism strategy than Curry County Commissioner Rocky McVay. Asked in December, 1987 why he was agreeing to jettison Curry County's favored fish enhancement strategy to adjoin Curry County to a multi-county tourism strategy, he replied "We don't have a lot of choice" (Oregonian December 20, 1987). Commissioner McVay and his fellow Southern Oregon officials believed that any strategy outcome not resulting in implementation of a multi-county tourism strategy would, at a minimum, have penalized them in terms of their lottery allocations and 
most probably, been vetoed outright by the governor. This is despite EDD Deputy Director David Lohman's promise, made during legislative hearings on HB 3011, that "the Governor would not be imposing his own ideas of what regions should be" (Joint Legislative Committee on Trade and Economic Development February 18, 1987).

\section{Strategy Membership Update}

January, 1987 saw Jackson, Josephine and Curry Counties pledged to implement a multi-county tourism strategy. January, 1987 also saw Klamath County pledged to implement a multi-county Southern Oregon tourism strategy. Its participation in the strategy compact proved tenuous, however, as Klamath County broke with the other counties in April, 1988 to unilaterally implement a strategy of its own choosing. Lake County has hitherto received little attention. Encompassing an area of 8,359 square miles, Lake County is Oregon's second largest county. With a population of only 7,600 , it was also Oregon's third least densely populated county in 1986 (Secretary of State 1987-88). Of all the county's involved in the Southern Oregon Strategy, Lake County appears to have most lacked the capacity for economic development planning. It appears less to have mounted any indigenous effort to select a Regional Strategy than to have simply sought to piggy-back upon the strategy efforts of surrounding counties. This led Lake County to also pledge itself to implementation of a multi-county tourism strategy in late 1987. As Figure I shows, Lake County's only contiguous link with the other counties involved in implementing the Southern Oregon strategy was through Klamath County. Klamath County's April, 1988 departure from the group severed this link. Subsequently, Lake County was joined in implementing a common strategy with Harney County, its equally sparsely populated neighboring county to the east. 
Initially, officials in Douglas County hoped to use Regional Strategies money to augment local industrial recruitment efforts. Subsequently, Douglas County decided to opt for a tourism strategy under Administration pressure (Robertson February 14, 1990; Gershon February 14, 1990; Graff February 14, 1990). However, Douglas County wanted to implement its tourism strategy not in conjunction with neighboring counties but alone. This led EDD's Bob Schumaker to rejoin that Douglas County would have to "prove that its [tourism] plan is different enough [from the others] to justify receiving separate funding (Oregonian December 20, 1987). It became clear that the Governor would not accept any Douglas County strategy not submitted as part of a greater multi-county strategy. Ultimately, Douglas County agreed to join the other counties in a multi-county tourism strategy compact, although not until the spring of 1988 , after a long but unsuccessful battle with the Administration.

\section{The Sunset Clause as Determinant of Gubernatorial Behavior}

The Goldschmidt Administration believed it would take several successive rounds of industrial targeting to promote economic restructuring in Oregon's less developed areas. It also viewed the Regional Strategies program as a vehicle for recruiting support for future electoral aspirations. For these reasons, it had sought ongoing authorization for Regional Strategies. Lawmakers inserted the Sunset Clause into HB 3011. Furthermore, the Administration knew of one test it would have to pass if it were to convince lawmakers to reauthorize Regional Strategies during the following legislative session. This was to see Regional Strategies implemented through multi-county regions. Trade and Economic Development Committee head Wayne Fawbush made this point when he said, during hearings on HB 3011, that he would consider Regional Strategies a "failure if it were not implemented through multi-county regions" (Joint Legislative Committee on Trade and Economic 
Development February 27, 1987).

The effect of the Sunset Clause was to transform reauthorization of Regional Strategies into a key Administration priority. Furthermore, the Administration envisaged implementation of a multi-county strategy in Southern Oregon as a vehicle for building support for program reauthorization. Governor Goldschmidt acknowledged these points himself. Appearing in Grants Pass made shortly after he had granted final approval to the Southern Oregon strategy, the Governor presented local officials with an oversized check symbolic of the assistance they were to receive under the aegis of their Regional Strategy, he praised the multi-county Southern Oregon Strategy effort as an example of "unprecedented cooperation." He went on to express his "hope that the 1989 legislature would again approve spending Oregon Lottery proceeds for regional development projects" (Mail Tribune August 23, 1988). By all indications, the forcefulness with which the Administration acted to ensure implementation of a multi-county tourism strategy in Southern Oregon was driven by its desire to see the program reauthorized. For cooperation amongst the Southern Oregon counties was more cursory than genuine and above all not innate but the product of gubernatorial intervention.

\section{The No-Seconds Rule as a Limit Upon Gubernatorial Success}

January 27,1988 , saw officials from the five counties pledged at the time to implement a multi-county tourism strategy--Jackson, Josephine, Klamath, Curry, and Lake--meet with staff from the Economic Development Department. They met to decide how to apportion the $\$ 2.08$ million in lottery money the Administration had announced it would make available for implementation of their regional strategy. Deliberations over the division of the lottery money point to the no-seconds clause as 
a legislatively-enforced constraint upon the Administration's ability to secure a key industrial policy goal.

The Administration argued for a collective pooling of the region's lottery allocation. Under this scheme, projects proposed for funding with the region's strategy money would have been competitively evaluated based upon their "regional significance"--the promise for promoting development of the region's tourism industry. This position was consistent with the Administration's goal, articulated by EDD's David Lohman in opposing the no-seconds clause before the legislature's T\&E Committee--that lottery funded projects be competitively evaluated. However, local officials favored an arrangement by which the region's strategy allocation would be divided amongst the counties on a per-capita basis. Each county would then be responsible for apportioning its respective share among local development projects as it saw fit (Brown October 30, 1989; Hamilton January 8, 1990; McGregor February 8, 1990; Wyatt February 13, 1990). In the end, it was on a per-capita basis that the region's strategy allocation was divided.

During legislative hearings on $\mathrm{HB} 3011$, the Administration went on record as being opposed to per-capita division of Regional Strategies money. The outcome in Southern Oregon represented a retreat for the Administration, especially when contrasted to the Central Oregon case, where moves to adopt a per-capita lottery division scheme were defeated. The key variable explaining these divergent outcomes appears to be the no-seconds clause, which expressed the legislature's intention of ensuring a comparatively equal distribution of state lottery money and which, not yet adopted at the time Central Oregon's project list was composed was law almost a year later when the Southem Oregon officials set out to compile their project lists (Campbell November 4, 1989; Lohman November 21, 1989; Reiten February 27, 
1990). In Southern Oregon, the effect of the no-seconds clause was to subordinate competitive evaluation of strategy proposals, initially a key Administration aim, to equity as a criteria for allocating state lottery money.

\section{THE PROJECT LIST}

Southern Oregon's project list is presented in Table VII. The list is divided into five separate components. There is one for each of the counties party to the final strategy compact, containing the projects they chose to fund with their respective shares of the region's lottery allocation. The list also contained a regional component, containing projects collectively sponsored, on which more will be said shortly.

Southern Oregon's project list is long. It contained a total of forty-two projects, three times the number of projects in Central Oregon's strategy. Therefore, only certain select projects are referred to in the discussion below, selected because they demonstrate the limit to the Administration's ability to use the Regional Strategies arrangement to leverage private sector investment and to overcome the institutional fragmentation characteristic of Oregon state government.

\section{The Vicissitudes of Private Capital}

Changes in the membership of the Southern Oregon Strategy group during the first half of 1988 resulted in a small increase in the amount of lottery money available to Southern Oregon for per-capita division, to $\$ 2.3$ million from the $\$ 2.08$ million first announced by the Administration. Josephine County's diffused and fragmented private tourism sector failed to nominate enough projects to exhaust Josephine County's lottery allocation, however. This created a void into which local governments stepped. From the heads of local government agencies, Josephine County's Commissioners collected a list of high priority public works and public 


\section{T.ABLE VII}

\section{SOUTHERN OREGON REGIONAL STRATEGY PROJECT LIST}

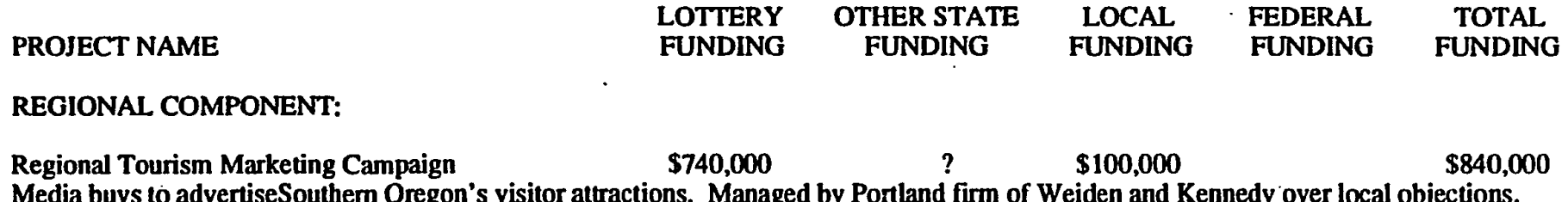

Media buys to advertiseSouthem Oregon's visitor attractions. Managed by Portland firm of Weiden and Kennedy'over local objections.

Regional Highway Improvements

Scale and timing of improvements, if any, to be determined by ODOT. Appears to have been a placeholder.

Crater Lake Lodge Renovation

$\$ 1,800,000 \$ \$ 1,800,000$

Renovation of historic lodge in Crater Lake Park. Congressionally funded, renovation would be made regardless of Regional Strategies.

\section{Interactive Video $\$ 215,000$}

Touch response television screens provide information at user request. A favorite project of Governor Goldschmidt.

$\$ 215,000$

Highway Signage

ODOT to install new highway signeage to region's visitor attractions.

Regional Tour Loop Theme

$?$

Funding to retain consultant to develop theme for scenic highway loop.

Total Regional Component Funding:
$\$ 50,000$

$\$ 1,005,000$
$\$ 50,000$

$\$ 100,000 \quad \$ 1,800,000 \quad \$ 2,905,000$


TABLE VII

SOUTHERN OREGON REGIONAL STRATEGY PROJECT LIST

(continued)

PROJECT NAME

LOTTERY

FUNDING

OTHER STATE LOCAL

FEDERAL

TOTAL

\section{JOSEPHINE COUNTY COMPONENT:}

Grants Pass Third Bridge

FUNDING

FUNDING

FUNDING

FUNDING

$\$ 500,000$

\section{Grants Pass Visitor Center}

$\$ 82,500$

$\$ 112,000$

$\$ 50,000$

$\$ 244,500$

Construction of new visitor center in Gran

$\begin{array}{lc}\text { Illinois River Information Center } & \mathbf{\$ 7 5 , 0 0 0} \\ \text { Construction of visitor center near Oregon Caves National Monument. }\end{array}$

$\$ 50,000$

$\$ 50,000$

$\$ 175,000$

$\$ 7,056,000$

$\$ 7,104,000$

Was to be used for fencing improvements to county airport abutting ranch. Local funds included $\$ 7,000,000$ to be privately invested by resort developer. Developer pulled out and lottery money was ultimately used to pave airport parking lot.

\section{Josephine County Fairgrounds Master Plan \\ $\$ 30,000$ \\ Development of a master plan for renovating Josephine County Fairgrounds.}

$\$ 50,000$

$\$ 80,000$

Indian Mary Park Ėntry Road

$\$ 19,000$

$\$ 10,000$

$\$ 2900$

Resurfacing of entry road at county park.

Hog Creek Boat Landing

$\$ 19,000$

$\$ 8,300$

$\$ 40,700$

$\$ 68,000$

Improvements to Rogue River boat landing. $\mathbf{\$ 1 9 , 0 0 0}$ in lottery money used to install restrooms; $\mathbf{\$ 8 , 3 0 0 0}$ in other state assistance was

froin Statc Marine Board for renovation of boat landing dock. 
TABLE VII

SOUTHERN OREGON REGIONAL STRATEGY PROJECT LIST

(continued)

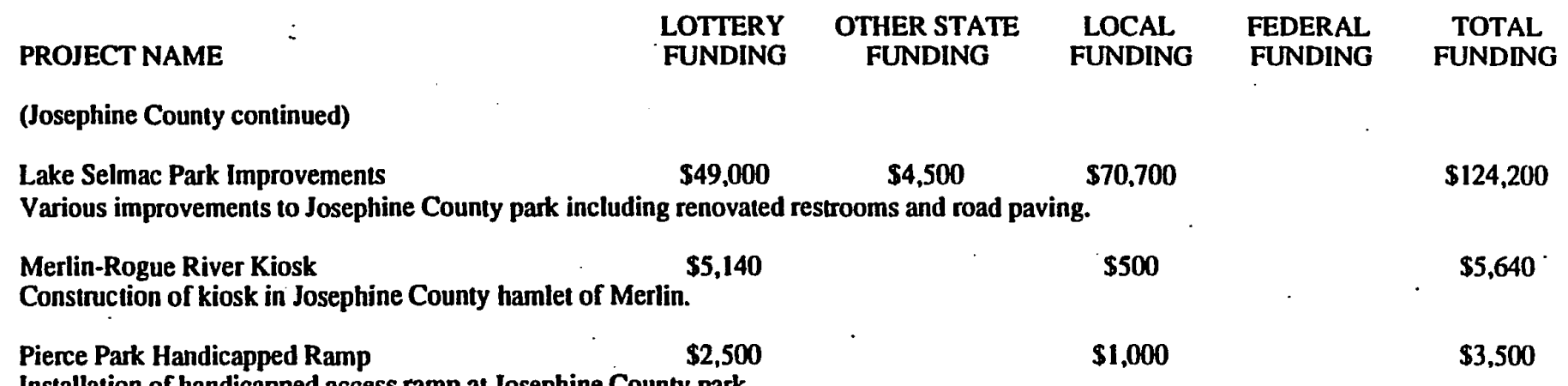

Installation of handicapped access ramp at Josephine County park.

Manzanita Kiosk

Local access provided to existing kiosk operated by ODOT. No cost involved.

Lathrop Boat Ramp Improvements

$\$ 71,000 \quad \$ 8,000$

$\$ 79,000$

State Marine Board to install new boat ramp at Josephine County park. Improvements were already in Marine Board capital improvement plan.

Lake Selmac Boat Ramp Improvements

$\$ 96,000$

$\$ 8,000$

$\$ 104,000$

State Marine Board to install new boat ramp at Josephine County park. Improvements were already in Marine Board capital improvetnent plan.

Total Josephine County

Component Funding:

$\$ 330,140$

$\$ 179,800$

$\$ 7,406,900$

$\$ 100,000$

$\$ 8,016,840$ 
TABLE VII

SOUTHERN OREGON REGIONAL STRATEGY PROJECT LIST

(continued)

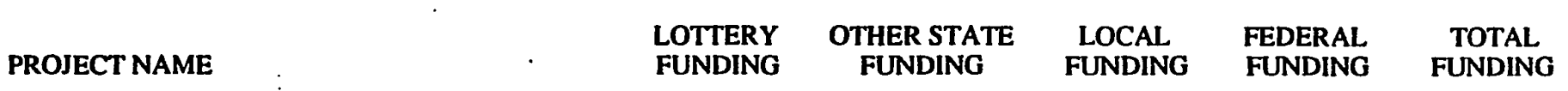

\section{JACKSON COUNTY COMPONENT:}

Crater Lake Highay Improvements

FUNDING

FUNDING

FUNDING

FUNDING

FUNDING

To accelerate construction of improvements already in ODOT capital improvement plan. Federal funds for improving

$\$ 4,820,000$

roadways within Crater Lake Park appropriated by Congress regardless of Regional Strategies.

Bear Creek Greenway

$\$ 124,439$

$\$ 180,000$

$\$ 2,259,013$

$\$ 85,700$

$\$ 2,649,152$

Constnuction of linear park.

$\$ 17,000$

$\$ 41,300$

$\$ 58,300$

Renovation of historic Irain depot in City of Gold Hill.

$\$ 200,000 \quad \$ 485,000 \quad \$ 300,000$

$\$ 985,000$

Subsidize installation of efficient wood burning stoves in low income households.

Exposition Park Improvements
Improvernents to Exposition Hall at County Fairgrounds.

$\$ 45,000 \quad \$ 53,646 \quad \$ 2,600$

Eagle point Street Landscaping
Landscaping of main street in city of Eagle Point.

$\$ 56,000 \quad \$ 32,000 \quad \$ 28,430$

$\$ 116,430$

Upper Rogue Park

$\$ 240,000$

$\$ 393,900$

Purchase of additional land to expand county park. $\$ \mathbf{1 8 5 , 0 0 0}$ of local funding in form of in-kind, tax deductable private donat

Medford Visitor Information Center

$\$ 25,000$

$\$ 58,184$

Construction of "log cabin" visitor center in Medford to which Chamber of Commerce will move offices. 
TABLE VII

SOUTHERN OREGON REGIONAL STRATEGY PROJECT LIST

(continued)

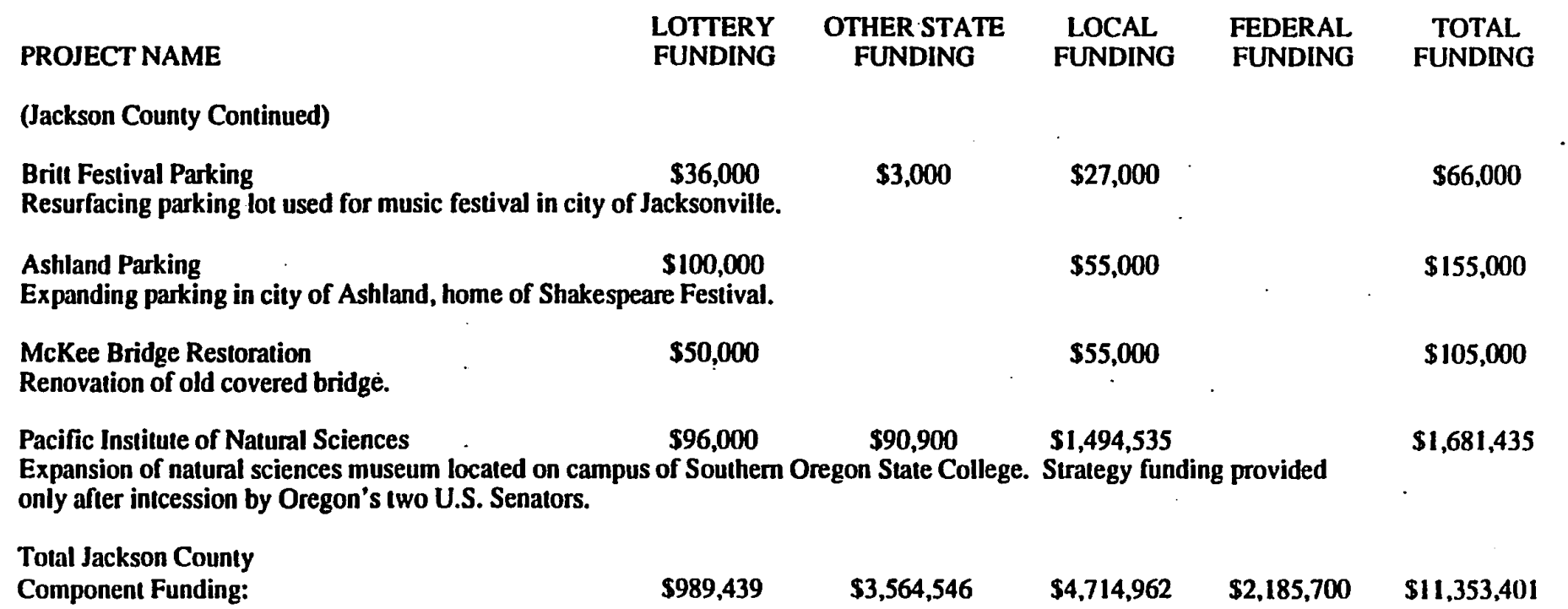


TABLE VII

SOUTHERN OREGON REGIONAL STRATEGY PROJECT LIST

(continued)

\section{PROJECT NAME}

LOTTERY

FUNDING
LOCAL FUNDING
FEDERAL FUNDING
TOTAL

FUNDING

\section{CURRY COUNTY COMPONENT:}

Brooking Right of Way

ODOT grants right of way for use as Chamber of Commerce parking lot. Administrative action, no funding involved.

Reforestation/Fish Rehabilitation

$\$ 184,000$

$\$ 234,000$

Replant burned state forest land.

\section{Sweet Hall Fairgrounds Improvements}

$\$ 10,000$

$\$ 87,000$

$\$ 50,400$

$\$ 147,400$

Brookings Chamber of Commence Parking Lot

$\$ 5,000$

$\$ 2,000$

$\$ 7,000$

Pave parking lot of Brookings Chamber of Commerce provided right of way by ODOT.

Port Orford Kiosk

$\$ 6,650$

$\$ 1,350$

$\$ 8,000$

Construction of Kiosk in Port Orford.

$\$ 100,000$

$\$ 50,000$

$\$ 150,000$

Renovate docks in city of Brookings.

$\$ 171,650$

$\$ 271,000$

$\$ 103,750$

$\$ 546,400$ 
TABLE VII

\section{SOUTHERN OREGON REGIONAL STRATEGY PROJECT LIST} (continued)

\begin{tabular}{|c|c|c|c|c|c|}
\hline PROJECT NAME & $\begin{array}{l}\text { LOTTERY } \\
\text { FUNDING }\end{array}$ & $\begin{array}{l}\text { OTHER STATE } \\
\text { FUNDING }\end{array}$ & $\begin{array}{l}\text { LOCAL } \\
\text { FUNDING }\end{array}$ & $\begin{array}{l}\text { FEDERAL } \\
\text { FUNDING }\end{array}$ & $\begin{array}{l}\text { TOTAL } \\
\text { FUNDING }\end{array}$ \\
\hline \multicolumn{6}{|l|}{ DOUGLAS COUNTY COMPONENT: } \\
\hline $\begin{array}{l}\text { Wildlife Safari } \\
\text { Improvements to Wildlife Safari located outside of Rose }\end{array}$ & $\begin{array}{l}\$ 365,000 \\
\text { burg. }\end{array}$ & & $\$ 1,185,320$ & & $\$ 1,550,320$ \\
\hline $\begin{array}{l}\text { Reedsport Sewer Replacement } \\
\text { Replace sections of sewer system in city of Reedsport }\end{array}$ & $\$ 152,415$ & $\$ 52,000$ & $\$ 100,000$ & & $\$ 304,415$ \\
\hline $\begin{array}{l}\text { South Umpqua Historical Museum } \\
\text { Improvements to Douglas County historical museum. }\end{array}$ & $\$ 50,000$ & & $\$ 175,300$ & & $\$ 225,300$ \\
\hline $\begin{array}{l}\text { Sawyer Rapid Boat Ramp } \\
\text { State Marine Board to install new boat ramp at Josephine }\end{array}$ & County $\mathbf{p}$ & $\begin{array}{l}\$ 35,000 \\
\text { Improvements were }\end{array}$ & $\begin{array}{l}\$ 110,000 \\
\text { Iready in Marir }\end{array}$ & Board ca & $\begin{array}{l}\$ 145,000 \\
\text { nprovement plan }\end{array}$ \\
\hline $\begin{array}{l}\text { Dean Creek Elk Viewing Area } \\
\text { Improvements to parking lot at elk viewing area by state }\end{array}$ & department of & $\begin{array}{l}\$ 205,000 \\
\text { ish and game. }\end{array}$ & & & $\$ 205,000$ \\
\hline $\begin{array}{l}\text { Total Douglas County } \\
\text { Cọmponent Funding: }\end{array}$ & $\$ 567,415$ & $\$ 292,000$ & $\$ 1,570,620$ & & $\$ 2,430,035$ \\
\hline AGGREGATE STRATEGY FUNDING: & $\$ 3,063,644$ & $\$ 4,307,346$ & $\$ 13,896,232$ & $\$ 4,085,700$ & $\$ 25,251,676$ \\
\hline
\end{tabular}

Source: Oregon Economic Development Department, nd. 
service projects. The Commissioners then brokered amongst themselves a list of those projects to be funded under the Strategy. Josephine County does not appear to have been along in encountering a deficit in privately sponsored strategy projects. Similar circumstances prevailed in Jackson County as well (Golden February 5, 1990; Leister February 6, 1990; Bartow February 8, 1990; McGregor February 8, 1990). Josephine County Fairgrounds Master Plan is a good example of the type of projects that emerged from this process. By law, the plan had to be completed before funds from a local improvement district could be tapped to replace the exhibition hall roof and make other improvements to the fairgrounds in Grants Pass, which is used for events such as the Josephine County fair, rodeos, livestock shows, almost all of which appealed almost wholly to local residents. Cash short officials in Josephine County had been seeking funds for Master Plan preparation. In Regional Strategies, they found the funding they were looking for (Bradbeer February 8, 1990). In Jackson County, this process produced $\$ 124,439$ in lottery funding to construct the Bear Creek Greenway recreational trail. The trail was listed at the behest of Medford's municipal parks department (Korbulic February 6, 1990). In fact, the city had already purchased property for the Greenway and had intended to pay most of the cost of trail construction itself through a bond issue. Lottery money allowed the Parks Department to install additional improvements. 4

Jackson County's air quality campaign points to another example of lottery money being used to meet local public service goals. Officials in Jackson County were under order by the Oregon Department of Environmental Quality to reduce particulate counts in the local air-shed. Towards this end, local officials planned a program to replace inefficient wood burning stoves used by many of the county's low income residents with more efficient models. Wood Stove replacement had been 
under way since 1986, paid for mainly with CDBG and other funds, which were running out. According to Gary Shaff (February 7, 1990), a local air quality planner, Jackson County officials saw Regional Strategies as a way of augmenting the CDBG funds and bringing the air-shed into air quality compliance.

The Paradise Ranch project is of special interest. It not only shows lottery money being used to augment local public works projects. More instructively, it highlights the fact that success in promoting economic transformation in Southern Oregon was contingent upon the vicissitudes of private market capital flows, upon which Goldschmidt Administration officials had little control and consequently, it demonstrates the limits to which public money could be used to induce private investment. Local officials sought to use Regional Strategies money to leverage West German investment in a plan to turn the dude ranch, located north of Grants Pass, into a major destination resort replete with an 18 hole golf course:

Because of the short term investment of $\$ 7,006,900$ and the long term commitment of an additional $\$ 18,023,100$ it is extremely important to the developers that the surrounding and pervading ambience reflect the high quality and luxuriances of the resort itself. Therefore, highway access improvements, to include a scenic corridor and airport access improvements, security fencing and additional airport parking facilities have been identified as high priority projects. The $\$ 250,000$ ODOT and $\$ 48,000$ [lottery] funds present a tremendous leveraging opportunity that will ensure investors are favorably convinced to see the project through (EDD nd b).

Subsequent to approval of Southern Oregon's strategy, the West German investors withdrew their Ranch expansion plans. The reasons are not entirely clear, but were apparently related to financing problems and other business commitments. According to Bruce Bartow (February 8, 1990), the County's Planning Director, EDD subsequently permitted the County to use the lottery money to pave the airport's parking lot, maintenance of which had been severely curtailed during the preceding years of economic crisis. 


\section{Overcoming Institutional Barriers}

The project list's regional component was created to encompass two projects, regional tourism marketing, and highway improvements. In each case, goal attainment required that barriers to institutional cohesion be overcome. The discretionary authority the Administration possessed under Regional Strategies over lottery spending enabled it to circumvent institutional barriers and boost funding for and centralize control over tourism marketing activities. In the case of the highway improvements, which was not contingent upon lottery funding but instead upon funding from the state's highly autonomous transportation department, the Regional Strategies arrangement proved less efficacious.

Selling Oregon in a New Way The impulse for funding a regional tourism marketing campaign under the Southern Oregon strategy arose with the Goldschmidt Administration. The projects prime proponent was Debbie Kennedy, who assumed office as the new head of EDD's tourism marketing division in August, 1987. Earlier, Kennedy had managed apparel marketing for the Canadian operations of Nike Inc., where she had earned a reputation as an aggressive marketing strategist. Introduced as EDD's new tourism chief at a press conference, she announced plans to remake the "Tourism Division as the marketing department of the state. Joining Kennedy at the news conference was her boss, EDD Director Dick Reiten. He echoed her remarks, announcing "We're going to sell Oregon in a new way (Oregonian August 19, 1987). The EDD officials clearly had a gubernatorial mandate to establish EDD as a vehicle for "selling Oregon." The former head of the Portland office of the business consulting firm Anderson and Company who, Reiten had only recently been appointed EDD Director by Governor Goldschmidt. Perhaps more telling, Kennedy appears to have been personally picked for the EDD role by Governor Goldschmidt. He was 
familiar with Kennedy's work since, prior to running for the Governor's office, he had worked as a Nike executive, where he had been Kennedy's boss.

Upon joining EDD, Debbie Kennedy inherited a tourism division budget of $\$ 4.5$ million. This was up almost $\$ 2$ million from the preceding 1985-87 biennium (Executive Department 1987). The Administration apparently did not view this sum as sufficient, for Kennedy went to great lengths to seek out other funding sources. For example, in late 1987, Kennedy proposed selling advertising in the state's official travel guide to raise an additional $\$ 500,000$ for EDD's tourism marketing activities (Oregonian November 5,1987 ). While it's unclear exactly what became of Kennedy's proposal to sell advertising in the state's official travel guide, it is clear that the Goldschmidt Administration embraced the expansion of state tourism marketing efforts as a key goal and was actively seeking to secure funding for this purpose.

When the Southern Oregon officials first agreed to endorse a regional tourism marketing campaign as part of their Strategy, they believed that they themselves would be responsible for its administration. In particular, they believed that they would themselves select an advertising agency to manage the marketing campaign. They intended to select a local concern. However in early June, 1987, not long before the Strategy was finalized, the Goldschmidt Administration announced that it would require the Portland advertising firm of Wieden and Kennedy (no relation to Debbie Kennedy) to develop and manage media buys for the Southern Oregon campaign. The Administration defended its decision to have Weiden and Kennedy manage Southern Oregon's tourism marketing in terms of the need to ensure consistency in Oregon's tourism marketing activities (Medford Mail Tribune June 6, 1988; Wyatt February 13, 1990). Earlier, in November, 1987, EDD had given the firm exclusive responsibility for developing and managing media buys for EDD's own mainstay tourism marketing 
initiatives. ${ }^{5}$ The Administration wanted to ensure that marketing materials developed under the terms of the Southern Oregon Strategy were consistent with the materials Weiden and Kennedy developed for EDD's mainstream effort.

The announcement that Weiden and Kennedy would direct Southern Oregon's tourism marketing campaign evoked sharp protest. One of the most vociferous critics was Patti Bills, director of the Greater Medford Visitors and Conventions. The Mail Tribune (June 6, 1988) quoted Bills as saying "We would like to make our own decisions and not have a Portland agency shoved down our throats." "County Commissioners from Jackson, Josephine, and Curry Counties met in Grants Pass and passed a resolution supporting local autonomy in choosing an ad agency. A copy of the resolution was sent to Governor Goldschmidt" (Mail Tribune June 6, 1988). In the event, these protests proved to be of no avail. Portland's Weiden and Kennedy did indeed wind up overseeing development and media buys for the Southern Oregon Strategy's tourism marketing campaign.

The tourism marketing campaign again shows the Administration using the extraordinary authority it possessed under the Regional Strategies program to impose its own policy preferences on local officials. The Administration secured two key goals in doing so. It boosted by $\$ 740,000$ the amount of money available to the Administration for "selling Oregon" and, by making Weiden and Kennedy responsible for administering Southern Oregon Strategy's tourism marketing activities, centralized Oregon's economic development marketing efforts.

The Personalization of Regional Strategies The Goldschmidt Administration envisaged Regional Strategies as a vehicle for coordinating Oregon's state government agencies. Regional Strategies did prove efficacious in getting ODOT officials to grant Josephine County access to a highway kiosk and in the Curry County land transfer. 
But according to ODOT administrator Jim Gix (February 14, 1990), these were relatively minor administrative matters involving neither capital improvement planning nor the expenditure of ODOT's fiscal resources, and so were easily accommodated. ${ }^{6}$ Regional Strategies proved less efficacious when it came to more substantive highway projects, as is shown by Southern Oregon's failure to use Regional Strategies to secure improvements to Highway 140, the region's major eastwest route.

Southern Oregon had for several years been attempting to secure improvements to Highway 140. Late 1987 found Southern Oregon seeking to secure these improvements by having Highway 140 listed under the Access Oregon Highways (AOH) program which, to recall, funded improvements from state gas tax surcharge revenues. The region valued the highway improvements highly, as a report in the February 24, 1988 edition of the Mail Tribune noted:

Southern Oregon's Highway 140 east-west route should be added to the list of "Access Oregon" projects included in the state's preliminary six-year highway improvement program, according to representatives of the five Southern Oregon counties. The east-west highway corridor stretches from Lake County in the east to Curry County at the coast. It was given the "highest regional priority" in a recommendations to the state Department of Transportation adopted Tuesday by the region's representatives.

The five counties--Josephine, Jackson, Curry, Lake, and Klamath, all of which were served by the Highway 140 corridor and which had, in January, 1988, agreed to join in implementing a common tourism strategy. Subsequently, they decided to follow Central Oregon's example and petition AOH listing of Highway 140 under the terms of their Regional Strategy. The question of using Regional Strategies to secure $\mathrm{AOH}$ listing of Highway 140 arose in a meeting between officials from the Southern Oregon counties, EDD and Jim Gix, manager of the transportation department's Southern Oregon region office. Recall how Administration attempts to subordinate the 
Commission to Gubernatorial authority had been defeated by the legislature. Funded largely through dedicated gas tax receipts and presided over by the quasi-independent Transportation Commission, ODOT was one of the most autonomous of Oregon's state government agencies. The local officials were told that ODOT did not view Highway 140 of sufficient importance to warrant $\mathrm{AOH}$ designation and therefore, Regional Strategies was unlikely to produce $\mathrm{AOH}$ listing for Highway 140. Instead, were told that regardless of whether or not Highway 140 received Strategy listing, requests for $\mathrm{AOH}$ listing of the 140 corridor would nonetheless have to work its way through the agency's well institutionalized six year capital programming process (Bartow February 8, 1990; McGregor February 8, 1990; Gix October 9, 1990). Regional Strategies does not in fact appear to have proved efficacious in securing Southern Oregon's highway improvements. For as Table VII shows, AOH listing for Highway 140 , mentioned only six months earlier as the "highest regional priority." received no mention in the final Southem Oregon Strategy. Although the Southern Oregon strategy contained no explicit reference to granting AOH status for Highway 140 , the Strategy did request outright other, unidentified, highway improvements. Local officials later cited this provision of their Strategy when lobbying ODOT, again unsuccessfully, for AOH listing of Highway 140. Exactly how this provision came to be included in the Southern Oregon Strategy is unclear. It has not resulted in AOH listing of Highway 140, however. As late as January, 1991, by which time construction of Central Oregon's highway improvements was well underway, Highway 140 had still not been incorporated into ODOT's AOH listing.

In seeking to use Regional Strategies to secure construction of its sought after highway improvements, Southern Oregon was following in the footsteps of Central Oregon. Yet, where Central Oregon succeeded, Southern Oregon failed. One factor 
that appears to explain these divergent outcomes is the extent of involvement by the state's transportation commissioners. Transportation Commission membership is divided along regional lines. Mike Hollern, Central Oregon's transportation commissioner, Transportation Commission head and close Goldschmidt associate personally intervened to secure the Central Oregon improvements. There is little evidence of similar mobilization by Southern Oregon's transportation commissioner, Cynthia Ford. This may have been due to her preoccupation with the newly established Pacific Institute of Natural Science (PINS), affiliated with the Southern Oregon State College in Ashland. A college official, Ford was responsible for overseeing PINS fund raising. One way she sought to raise money was to seek lottery funding under Regional Strategies. This consumed a lot of Ford's energy. For reasons unclear, the Goldschmidt Administration opposed lottery funding for PINS (Ford February 6, 1990; Wyatt Interview February 13, 1990). It was only after Ford elicited the help of Oregon's two U.S. Senators, Mark O. Hatfield, after whom a PINS facility was named, and Bob Backwood, who in a letter dated May 13, 1988, supported "this important project for Oregon and for the nation" (Letter to Dr. Ron Lamb from Senator Bob Packwood dated May 13, 1988), that the Administration relented and allowed the PINS request to be inserted into Southern Oregon's strategy. As a corollary, PINS points to a strategy project which clearly came to be funded nit as a matter of objective analysis but due to the personal intervention of two of Oregon's most powerful politicians. 


\section{SUMMARY}

Implementation of Regional Strategies in Southern Oregon saw the Goldschmidt Administration override local preferences in a region afflicted with centrifugal forces and weak in local planning capacity to implement a multi-county tourism strategy. In the absence a private tourism sector capable of sponsoring strategy projects, local governments capture lottery money for use in funding local public works and public service projects. While in the regional marketing campaign, the Administration succeeded in consolidating control over tourism marketing and boosting funding for tourism marketing, the Administration proved less successful when dealing with ODOT, an autonomous agency. The failure of the Paradise Ranch project to materialize points to the limitations of the Regional Strategies arrangement to overcome the vicissitudes and induce private capital investment. 


\section{NOTES}

1. That so many counties were involved in implementing the Southern Oregon strategy and undertook their Strategy activities largely exclusive of each other made presenting an analysis of the Southern Oregon Strategy a significantly more complex task than that posed in Central Oregon. To best capture the complexities of the Southern Oregon Strategy within a manageable framework, I have focused my attention upon the two counties at the core of the Southern Oregon Strategy effort-Jackson and Josephine Counties. The other counties involved in the Southern Oregon Strategy are brought into the discussion only occasionally, mainly to add emphasis to points made within the context of the Jackson and Jefferson County strategy experiences. Little of substance is lost with this approach since, for the most part, the dynamics of the Strategy process in those counties which are not the center of attention here differed little from those upon which attention is focused.

2. Goldschmidt may also have entwined the Strategy process with Mayor Reyneke's personal political ambitions. According to Mayor Reyneke (February 8, 1990), Goldschmidt also encouraged her to seek higher office. His recommendation played a key role in her decision, announced in 1988, as Josephine County's strategy effort was winding down, to run for a seat in the state House of Representatives. Mayor Reyneke's bid for a seat in the Oregon House of Representatives proved unsuccessful. She attributed her failure to her decision to switch parties.

3. The nomination of secondary wood products as a strategy option in Josephine County raised the question of what role local mill work and logging interests played in the strategy selection process. This issue was addressed with Mike Burrill (February 7, 1990), President of Burrill Lumber, perhaps Southern Oregon's largest independent manufacturer of primary processed lumber products. According to Burrill, Oregon's wood products producers saw little reason to involve themselves in Regional Strategies. As Burrill explained it, Oregon's mill owners and logging interests have traditionally targeted their political interventions not at the statehouse but at the federal government. The reason can be appreciated in noting that together, the U.S. Forest Service and U.S. Bureau of Land Management control over half of the state's total land area (Secretary of State 1986-87). Much of this is land from which the timber supply that feeds Oregon's mill works is drawn. In contrast, state forests provide only a small share of harvested timber.

Also, it is construction activity, especially housing, which consumes most of the mill's production. Housing construction is highly sensitive to interest rates which are largely determined by federal policy action. Again then, the fortunes of logging and mill working interests appears to have been primarily dependent upon federal policy and, not unimportantly, how federal policy influences exogenous markets, not upon the state apparatus and state policy choices.

Apart from their long standing dependence upon federal timber supplies, Oregon's mill work and logging interests faced a particularly urgent issue during the winter of 1986-87. Environmentalists had inaugurated a campaign to have the Northern Spotted Owl designated an endangered species by the U.S. Fish and Wildlife Service. Designation would have necessitated creation of protective habitats which would curtail logging of the state's diminishing supply of old growth forest. Loggers and mill owners saw this as a direct threat to their interests, one demanding that their 
political resources be focused upon influencing federal action and not state development initiatives. In sum, the absence of Oregon's mill works and logging interests from Regional Strategies activities appears to have been largely explained by the fact that their fortunes were largely determined by an exogenous federal bureaucracy and hence, saw little reason to expend scarce political capital on a state initiative in which they recognized little prospective benefit.

4. The balance of the cost for constructing the trail was to be paid for by AT\&T, in return for rights to install fiber optic cables underneath, a contribution which was recorded as the private sector contribution to this project (EDD nd c).

5. Discussion in this section highlights something of a Nike connection running through the Goldschmidt Administration. Governor Goldschmidt himself worked for Nike prior to running for Governor. So did EDD's Debbie Kennedy. Weiden and Kennedy, chosen to manage Oregon's tourism marketing campaign, handled Nike's advertising.

6. Evidence relating to the efficacy of Regional Strategies in bringing other projects petitioned from ODOT is largely inconclusive. For example, Jackson County's Crater Lake Highway improvements had been listed at the behest of local officials who feared that these improvements would be delayed beyond 1988, when their construction was originally scheduled in ODOT's six year plan. As it happened, there was no delay in the construction of these improvements. But ODOT's Jim Gix (February 14, 1990) claimed this had little to do with Regional Strategies and was instead attributable to the availability of necessary funding. In fact, Gix suggested that EDD may have urged inclusion of the Crater Lake improvements in the strategy knowing that they would indeed be initiated on time so as to give the appearance that they were attributable to Regional Strategies. 


\section{CHAPTER VIII}

\section{IMPLEMENTING REGIONAL STRATEGIES IN KLAMATH COUNTY}

Recall from the preceding chapter that Klamath County was for some time involved in the Southern Oregon Regional Strategy but ultimately departed to pursue its own unilateral strategy. The circumstances under which Klamath County did so warrant an in-depth analysis in their own right, apart from the references to Klamath County contained in the preceding chapter.

Discussion in this chapter point to limitations upon the Goldschmidt Administration's ability to wield the discretionary authority it enjoyed over state lottery spending to secure key industrial policy goals. In Klamath County, a powerful growth coalition captured control of the Regional Strategies implementation process. The coalition aimed to use the Regional Strategies program as a vehicle for pursuing an economic development agenda revolving around construction of a controversial power dam and in contravention of the Goldschmidt Administration's preference for joining Klamath County to the larger multi-county tourism strategy. In the end, Klamath County's Regional Strategy embodied not the Administration's goals but those of the local growth coalition. Local success in defying gubernatorial authority was attributable to the capacity advantages coalition forces possessed for planning and mobilizing for economic development which allowed it to dominate other factions of the local polity and the coalition's fiscal independence from state revenues. 


\section{ECONOMIC CRISIS IN KLAMATH COUNTY}

Klamath County occupies a large basin on the eastern edge of the Cascade Mountains in Southem Oregon (Figure I). The Mountains cast a rain shadow on the basin making Klamath County much more arid than, for example, Jackson and Josephine Counties to the west. The dry conditions make the area ideal habitat for Ponderosa Pine trees, one of the more valuable of the timber species harvested in the Pacific Northwest. Not coincidentally, wood products, as with so much of Oregon, has traditionally dominated the local Klamath County economy.

As the downturn of the 1980 s set in, wood products employment dropped precipitously in Klamath County, from over 4,900 to 3,000 between 1979 and 1985, a decline of almost 40 percent (Employment Division 1979; 1985). At the same time, there were other shocks afflicting the Klamath County economy. Klamath Falls, the County's largest city, accounting for almost two-thirds of the County's total 1980 population of 58,000 , has traditionally served as a communications and transportation center for much of central and southeastern Oregon (Department of Commerce 1980). But during the early 1980's, the regional telephone company that succeeded the breakup of the Bell network decided to transfer its Klamath Falls operations to Medford while the Southern Pacific Railroad transferred many of its Klamath Falls' operations to Eugene. Also during this period, the Pentagon decided to close down the air station at Kingsley Field, located on the outskirts of Klamath Falls. These moves only cut more jobs out of the local economy.

Klamath County's unemployment rate reached 20 percent during the winter of 1981-82 and remained well above the statewide average through 1986 (Employment Division 1986). There was a commensurate decline in the County's 
population--by 2500 or 4 percent of the total in just the six years between 1980 and 1986 (Secretary of State 1987-1988)--as people left to search for work elsewhere. So stilled did the local real estate market become that the County's largest banks withdrew their realty loan officers to Medford. Recall from an earlier chapter that the Ministerial Association in Klamath Falls reported that counseling for drug, alcohol, and child abuse increased tenfold during the first half of the 1980s. Placed in perspective, the distress Klamath County experienced during this period must have rivaled any other county in the state.

\section{THE SALT CAVES DAM}

The Pacific Power and Light Company (PP\&L) first announced plans to construct the 80 megawatt Salt Caves Dam in February, 1980.1 PP\&L planned to build the dam on a stretch of the Klamath River prized for its wild and scenic attributes, evoking vehement opposition from environmentalists nationwide. Others questioned the need for a new power dam at a time of regional electricity surplus. Faced with environmentalist opposition and questions over whether or not there was a market for the dam's power, PP\&L was unable to win licensing for the dam. In 1984, PP\&L announced that it was abandoning its plans to build Salt Caves. It was only shortly thereafter that the city of Klamath Falls announced plans to pick up the Salt Caves project where PP\&L had left off.

The city decided to build the dam as a remedy to the area's declining economic fortunes. According to city officials, Salt Caves would be a cure for local economic ills. Power sale revenues would be used to develop industrial parks in Klamath Falls and to subsidize the relocation of industry to these facilities, creating jobs and generating tax revenues. City officials also planned to tap power revenues to 
reduce municipal property taxes by as much as 50 percent (Keller January 8, 1990; Spencer January 8, 1990). With these lofty goals in mind, the city of Klamath Falls issued $\$ 250$ million in revenue bonds in May, 1985 , the proceeds from which were placed in a trust account to be drawn upon for use in promoting, planning, and constructing the dam.

\section{Operation Bootstrap}

Prior to assuming the office of President of the Oregon Institute of Technology in Klamath Falls, Dr. Larry Blake had worked in the North Carolina community college system, where he been involved in implementing a statewide economic development initiative. Based upon this experience, Blake had offered to assist both Neil Goldschmidt and Norma Paulus in fashioning a statewide economic development strategy during the 1986 gubernatorial campaign. Goldschmidt alone had responded to this overture, inviting Blake to attend a retreat held during the Summer of 1986. According to Blake (January 8, 1990), Goldschmidt largely ignored his suggestions. ${ }^{2}$ But Blake was still one of the three local officials Goldschmidt invited to inaugurate Regional Strategies in Southern Oregon.

Meeting with the Klamath County Board of Commissioners, Blake recommended that responsibility for identifying the County's Strategy be delegated to Team Klamath. Team Klamath had been formed in October, 1985 by the Klamath Falls Chamber of Commerce, and was composed of five local officials: Blake, who chaired the group, the President of the Klamath Falls Chamber of Commerce, the Klamath Falls City Manager, the chairman of the Klamath County Board of Commissioners, and the Executive Director of the Klamath County Economic Development Association, a quasi-public agency that functioned largely as the industrial promotions arm of Klamath Falls City government. According to the 
Klamath Falls Herald and News (January 29, 1986), the group was supposed to act as a local economic development coordinating council, defining "the roles and responsibilities of agencies, organizations and individuals involved in [local] economic development and funding." But it is instructive to note that all of those appointed to Team Klamath supported construction of the Salt Caves dam (Plummer January 12, 1990). As shall be seen, it appears that more than anything, Team Klamath had been created as a vehicle for mobilizing local support for building Salt Caves.

It was but a matter of weeks after Team Klamath assumed responsibility for identifying Klamath County's Regional Strategy that the panel was ready with a strategy proposal. The proposal was divided into two parts. The first was referred to as the proposal's "small business" component and listed three projects for which state assistance was requested. The second part of the proposal, the "tourism" component, listed two projects (Team Klamath 1987c).

The first project listed in the small business component petitioned the Governor to order all state agencies with regulatory authority over the Salt Caves Dam to expedite any required licensing review. This request was aimed primarily at the state's Department of Environmental Quality and Public Utility Commission: both agencies had expressed reservations over the dam project. Second was a venture capital fund to be used in recruiting new industry to the area. No state money was requested for the venture capital fund. Instead it was to be fully funded with revenues from the Salt Caves Dam. Project number three was development of a small business incubator at an industrial park located next to the OIT campus. For this, $\$ 50,000$ in state lottery money was requested. Again, the balance of the incubator costs were to be paid for by Salt Caves revenues. 
As regards the tourism component's two projects, the first petitioned the Governor to use the powers of his office in expediting review of the application the City of Klamath Falls had pending before the U.S. Forest Service for development of a ski complex on Pelican Butte, located about 25 miles north of the city itself. Development of the Pelican Butte complex was to be paid for with revenues from the Salt Caves Dam so no lottery money was sought for this purpose. But like the dam, the Pelican Butte project had proved quite controversial--the Butte's slopes were considered by many to be ill-suited to such development-- and the Forest Service had been slow to act on the City's development application. The second project listed in the tourism component was a request for $\$ 400,000$ in lottery money to build a Welcome Center in the Klamath Falls area.

With the exception of the Welcome Center, all of the projects listed in the Team Klamath proposal had been drawn from a plan prepared for the City of Klamath Falls by the prominent Boston consultant Belden Daniels. The plan's purpose was to guide use of the revenues generated by Salt Caves Dam and Daniels had been paid for his efforts with arbitrage funds drawn from the interest being earned by the City from its Salt Caves bond trust fund. ${ }^{3}$ The Daniel's plan had been entitled "Operation Bootstrap" and it was as the Bootstrap proposal that this Strategy scheme came to be known. It would be hard to argue that the main aim of the Bootstrap proposal was to capture state lottery dollars for local use. Most of the lottery money requested in the Bootstrap proposal was for building the Welcome Center, which would have been modeled upon the one planned for Central Oregon. But unlike Central Oregon, where the Welcome Center was the Strategy centerpiece, it was wholly peripheral to Team Klamath's proposal. In fact, the Welcome Center appears to have been included in the proposal only to make it more palatable to the Governor who, as Team Klamath knew, 
had expressed his preference for regional tourism strategies. As Klamath Falls City Manager Jim Keller, one of the key architects of the Bootstrap proposal, admitted (January 8, 1990), Team Klamath would have been willing to forego Klamath County's entire lottery allocation for the Governor's endorsement of Salt Caves. In Keller's view, if the Governor approved the Bootstrap proposal, he would effectively be sanctioning construction of the controversial dam. The Bootstrap proposal had but one purpose: to engender the Governor's endorsement of Salt Caves.

\section{The Salt Caves Opponents}

The dismal state of the local economy not withstanding, there were those in Klamath County who opposed construction of the Salt Caves Dam. ${ }^{4}$ The stretch of river upon which the City planned to construct the dam was prized by local fisherman and rafting enthusiasts. Dam construction would end these uses, ensuring strong opposition to the dam among the area's outdoorsmen and outfitting businesses. As with Jackson and Josephine Counties, Klamath County had a large retiree population and many of the retirees fished the river, giving them reason to oppose Salt Caves. Many of the retirees also feared that growth spawned by constructing the dam would undermine the amenities that had attracted them to the area in the first place. There was also opposition to the dam among faculty and staff at OIT. School faculty and staff were better insulated from the downturn than the County population in general and like the retirees, feared the impact dam- induced growth might have upon local amenities. Retirees, OIT faculty and staffers, outdoors-oriented business owners, and local environmentalists formed the core of local opposition to the Salt Caves Dam.

The Salt Caves opponents do not appear to have been organized in any formal manner. But if one were searching to identify the leaders of the dam opposition, they would have to include Roger Hamilton, rancher, environmentalist and 
rafting enthusiast from eastern Klamath County. So staunch an opponent was Hamilton that back when PP\&L had been sponsoring the dam, he had flown to Washington D.C., at his own expense, to register his objections at licensing hearings conducted by the Federal Energy Regulatory Commission. Hamilton was also an elected Klamath County Commissioner, and his opposition to the dam placed him at odds with the rest of the local political establishment, including his two colleagues on the County Board of Commissioners, Jim Rogers, who, as Board Chairman, sat on Team Klamath, and Ted Lindow, both of whom supported building the Salt Caves Dam (Hamilton January 8, 1990; Lindow January 9, 1990).

\section{Operation Bootstrap Repudiated}

Since the Bootstrap proposal was largely adopted from the Belden Daniel's plan, Team Klamath was able to have it ready for presentation to the Governor when he visited Klamath Falls in early May, 1987. As shall be demonstrated shortly, Goldschmidt recognized the Bootstrap proposal for what it was--an attempt to warm his support for Salt Caves.

Like Goldschmidt, Roger Hamilton recognized the Bootstrap proposal as a vehicle for promoting the Salt Caves. In a letter to the Governor dated May 7, 1987, he objected to Team Klamath's plans to found Klamath County's Strategy upon the proposal. Introducing his letter as a "minority report"--a dissent from Team Klamath's proposal-- Hamilton argued that the Bootstrap proposal did not represent the views of "a large portion of Klamath County residents." This was his veiled way of protesting the closed process by which, as we will see, Team Klamath conducted its proceedings. Less allusively, Hamilton argued that the timeframe implied in constructing a dam, the centerpiece of the Bootstrap proposal from which revenues to support the other proposal projects would be drawn, exceeded the time frame targeted for the Regional 
Strategies. Furthermore, he claimed that construction of the dam would destroy

existing rafting and fisheries industries that depended upon the untamed river, harming the local economy. Last, Hamilton protested that the Bootstrap proposal was incompatible with the type of multi- county strategy the Governor was known to favor (Letter to Governor Neil Goldschmidt from Roger Hamilton dated May, 7, 1987).

In correspondence dated July 9, 1987, Goldschmidt responded to Hamilton's concerns:

I appreciate your providing me with a copy of your "minority" report on the Klamath County Strategy. As you may or may not be aware, I voiced some of the same concerns at an early May meeting. Specifically, my concerns centered around the fact that the Salt Caves project and the revenues emanating from it were the "sine qua non" of the Klamath County Strategy. Given the permit and construction requirements for the project, all indications are that the project would be 10 years in the making and, therefore, that the revenues and ability to parlay the revenues for Operation Bootstrap and the Pelican Butte development would not be available until even further down the line.

As a member of the Klamath County Commission, you have an opportunity to ensure that these concerns are addressed prior to the county's adoption of the Strategy, and I encourage you to use this opportunity. For my part, I have taken the liberty of forwarding a copy of your letter to...Lise Glancy in the Economic Development Department to ensure that the "minority" report receives consideration in the regional strategy arena (Letter to Commissioner Roger Hamilton from Governor Neil Goldschmidt dated July, 9, 1987).

Team Klamath withdrew the Bootstrap proposal shortly after Goldschmidt's

letter was mailed. While interviews failed to discern a concrete explanation for the withdrawal, it appears certain that the proposal's demise was prompted by the Governor's letter, which can be seen only as repudiating the proposal. This seems especially clear in light of the fact that later in the summer, Goldschmidt formally announced his opposition to the Salt Caves dam. 


\section{The Light Industry Proposal}

Team Klamath did not wait long to develop a replacement in the wake of the Bootstrap proposal's demise. As it happened, the replacement, which came to be known as the Light Industry proposal, was largely complete by July, 1987.

The Light Industry proposal sought state assistance for six projects. First, the Governor's assistance was sought in getting the Oregon State Board of Higher Education to fund a Masters of Science program at OIT. Next, $\$ 300,000$ in lottery money was requested to establish a small business incubator on land adjacent to the OIT campus. Third was a request for $\$ 270,000$ in lottery money for use in an industrial marketing program. Fourth was a request for $\$ 153,000$ in lottery money to establish a user fee customs station--a customs station which, unlike typical customs facilities which are paid for by the federal government, is paid for by local authorities--at Kingsley Field, the air station abandoned by the Pentagon. Fifth was a request for a grant of $\$ 1,000,000$ from the state's special public works fund, to be used for making infrastructure improvements to land adjacent to the airfield, where the city planned to build an industrial park. 5 Sixth and last were improvements to Highway 62, which connected Klamath Falls to Interstate 5 at Medford (Team Klamath 1987a).

The Light Industry proposal is an excellent vehicle for examining the character of the Team Klamath coalition from which it emerged. This being so, it is to this end that attention now turns.

\section{Institution Building at OIT}

The Oregon Institute of Technology is one of the eight colleges and universities that comprise the Oregon State System of Higher Education. Although the school grants four year bachelor's degrees in engineering, business and medical 
technology, the school's curriculum is primarily vocational in nature. Most OIT graduates take two year associate degrees with them, either transferring to another college or university or more often, directly into professional practice. In fact, according to John Ward (January 9, 1990), OIT Professor of Industrial Management, more than anything, the school is renowned for graduating a large share of the nation's land surveyors. OIT has never offered graduate level courses.

Clearly, OIT is not the type of research oriented polytechnic that one might intuitively associate with its name. One of the objectives of Dr. Larry Blake, OIT's President, appears to have been to upgrade the school into a four year and graduate degree granting institution and a major component of Oregon's higher education system. His strategy for doing so appears to have been based largely upon efforts to recreate, on a much smaller scale, the type of business-education consortium that had produced the so- called "Research Triangle" in North Carolina where Blake had worked before coming to OIT.

In 1973, Blake convinced the City of Klamath Falls to construct the College Industrial Park on land abutting the OIT campus. Blake hoped that the park's proximity to OIT would attract high technology firms. Concomitantly, Blake hoped that the park's success would help him in his effort to obtain permission and funding from the Oregon State Board of Higher Education to establish a Masters program at OIT.

The College Industrial Park appeared devoid of major tenants when visited by the writer in January, 1990. With the fierce battle which has traditionally raged in Oregon over the distribution of higher education dollars--this battle was especially fierce amid the fiscal crisis of the first half of the 1980s--Blake was unsuccessful in obtaining approval and funding for his graduate program. 


\section{$\underline{\text { Kingsley Field }}$}

Kingsley Field, located just south of the City of Klamath Falls, had been built as an Army Air Corps base during the Second World War. Subsequently improved, it was, at the time of this writing, the second longest air strip on the west coast of the United States. Being located in the rain shadow of the Cascade mountains, Kingsley Field also records more days of sunshine in an average year than other west coast airstrips (Business Facilities 1988). Air traffic at Kingsley Field is rarely curtailed on account of weather. These factors have led to Kinglsey Field being designated as an alternative landing strip for NASA's Space Shuttles.

Local officials had long sought a plan for commercializing the airfield's attributes. The closing of the air base injected some urgency into these efforts and by early 1987, a scheme had emerged under which the city planned to develop Kingsley field as a air-freight center. Concurrently, land adjacent to the air field would be developed into an industrial park. It was hoped that this arrangement would transform the airfield and its environs into a center of light manufacturing and goods warehousing and distribution.

The Klamath Falls' Chamber of Commerce was a key proponent of the Kingsley Field plan. The Chamber represented Klamath County's business elites. Its Board of Directors included Dick Wendt, President of Jel-Wendt Corp., whose holdings included Southwest Valley Bank, the County's only locally owned bank and local millworks. Also on the Board was Jim Stillwell, perhaps the County's most prominent realtor and the owner of much of the land adjacent to the airport that was slated for industrial park development (Ward January 9, 1990). 


\section{$\underline{\text { Klamath County's Growth Coalition }}$}

It was the Chamber of Commerce which had appointed Team Klamath and designated OIT's Blake as the panel's chairman. Blake believed that any success he had in upgrading OIT would enhance the local economy or more to the point, believed that an upgraded OIT could be the engine that drove local economic restructuring. Blake's view in this matter and how OIT fit into the Light Industry proposal is perhaps summed up in the following passage:

[OIT's] facilities will provide the expertise required by companies locating here. A masters program will allow entry level engineers of those companies to expand their education, thereby providing an additional incentive for the company to locate all of its operations in Klamath County. The Small Business Incubator...to be located adjacent to OIT...will provide a support environment for starting companies. Overhead costs are reduced during their initial start-up period. Locating the incubator next to OIT will allow it to take advantage of the college's technology library, its computer systems, its labor force of students for part-time and its professors for consulting work. Likewise locating there will allow students and professors alike to start their own high technology businesses in the sheltered environment (EDD nd $\mathrm{c}$ ).

The Klamath Falls Chamber of Commerce and the other proponents of the Kingsley Field plan were not oblivious to the fact that their aspirations to turn Klamath Falls into a manufacturing and distribution center were shared by other localities up and down the west coast. Many of these communities were similarly engaged in developing industrial parks with which to lure business. Many of these other communities had better highway connections than Klamath Falls was ever likely to have. Klamath Falls was not even alone in being able to tie a retired military airfield to its industrial development scheme. The city of Sacramento, located only 300 miles to the South, was reputed to be planning a similar arrangement for Maher Air Force Base, which was also slated for closure by the Pentagon. In the eyes of the airport plan proponents then, any success Blake might have in upgrading OIT could 
only serve to imbue the area with an advantage relative to these competitors, increasing the area's attraction to the types of firms they hoped to lure to Klamath Falls:

In evaluating the assets of the Klamath Basin, every recent technical economic analysis has cited OIT as the major comparative advantage over similar communities in Oregon and northern California (EDD nd $\mathrm{c}$ ).

The convergence of interest that bound the local government, business, and education elites together behind the Light Industry proposal is as follows. In the proposal, Blake got to pursue the incubator project which he hoped, in conjunction with the Masters program he was also seeking, would increase his school's prestige and revitalize the College industrial park, impressing legislator's to further focus more of the state's higher education resources upon OIT and fuel local economic restructuring. At the same time, the Kingsley Field boosters got to petition support for the customs station, marketing program, infrastructure improvements, and highway improvements that they saw as necessary to the airfield development project.

Then there was the Salt Caves Dam. To recall, all of the Team Klamath members supported the dam's construction. In fact, the Kinglsey Field scheme was a spinoff of Salt Caves: the city planned to use revenues made available from Salt Caves to develop the airfield industrial park and subsidize the recruitment of industries. As Klamath Falls' City Manager Jim Keller (January 8, 1990) admitted, Team Klamath saw the Light Industry proposal as a "stepping stone" to Salt Caves.

\section{Capacity Advantage in Klamath County}

The Light Industry proposal also provides some measure of Team Klamath's capacity for economic development planning. We can see this capacity as being manifest in terms of human and technical capacity, for example, in the contribution 
Blake, experienced in economic development planning in North Carolina, was able to contribute to the proposal. Likewise in the Light Industry proposal, we can see manifestation of the fiscal, as well again as the technical capacity available to Team Klamath. For example, in preparing the proposal, Team Klamath drew upon reports such as the "Industrial Profile for Klamath County, Oregon," prepared by SRI International, one of the nation's most prominent economic consulting firms (EDD nd c). The SRI study had been commissioned by the city of Klamath Falls and paid for with Salt Caves arbitrage funds of which the city would spend an estimated $\$ 50$ million on other studies and projects between 1986 and 1991 (Satchell February 28, 1991). Team Klamath also used a report drawn up by the Salem, Oregon consulting firm of VBB Allen in preparing the Light Industry proposal. The report was part of a package of services for which the city of Klamath Falls was to pay VBB Allen in excess of $\$ 800,000$ in Salt Caves arbitrage funds.(VBB Allen 1987).

The conclusion warranted here is clear. In laboring to develop a Regional Strategy for Klamath County, Team Klamath possessed considerably greater human, fiscal, and technical capacity for economic development planning than, for example, their counterparts in their neighboring Southern Oregon counties.

\section{THE TOURISM COALITION}

In the spring of 1987, OIT Professor of Industrial Management John Ward began work on a proposal to target tourism as Klamath County's regional strategy. His interests in doing so could be seen as an outgrowth of his position as director of OIT's Small Business Development Center where, in 1986, he had received a grant for developing a plan for expanding tourism in Klamath County. But Ward was also an

opponent of the Salt caves Dam and like County Commissioner Roger Hamilton, with 
whom he was well acquainted, saw development of a tourism proposal as the most likely way of undermining Team Klamath's plan to use Regional Strategies as a precursor to Salt Caves (J. Ward January 9, 1990). Ward was to become, with Hamilton, the leader of a Klamath County tourism strategy coalition.

By late July, 1987, Ward had developed a draft proposal which listed more than twenty projects which he believed could enhance Klamath County's tourism industry. A sampling of these projects could read as follows: construction of a snow park in north Klamath County; construction of an ice skating rink in Klamath Falls; funding an eligibility study of granting protected status to three rivers under the state's Wild and Scenic Rivers Act--the Sycan, Sprague, and the Lower Williamson; and construction of low cost worker housing near lodges located in the County's northwestern quarter. As this brief account suggests, Ward's proposal reflected the input of the County's tourism and environmental interests, the essence of the coalition opposed to the Salt Caves Dam. But while the coalition behind Ward's proposal did not lack ideas for projects that might expand tourism, the proposal did lack a committed list of sponsors for most of the projects mentioned.

Tourism Proposal Denied Matching Funds

Even more than in neighboring Jackson and Josephine Counties, the main visitor attractions in Klamath County are natural resources: Lake Klamath and the Klamath River which attract fisherman and the latter, rafters, and Crater Lake National Park, the ancient volcano sporting in its now extinct cinder cone the deepest lake in North America. The types of businesses supported by these attractions are small lodging establishments and sporting goods and outdoors outfitters, convenience stores and gas stations, catering primarily either to wayfarers or outdoorsmen. Klamath County is the third largest County in Oregon (6,135 square miles) and far from being 
geographically concentrated, the County's visitor industries are territorially dispersed (Secretary of State 1987-89). In consequence, Klamath County's tourism sector was, not unlike those of Jackson and Josephine Counties, diffuse and highly fragmented, so much so that it was only in 1986 that an effort was made to establish an umbrella group to represent tourism interests countywide (Herald and News April 5, 1986). Earlier, local tourism interests were represented by at least four different and poorly coordinated organizations (Ward January 9, 1990). 6

Like their counterparts in Jackson and Josephine Counties, the businesses that comprised Klamath County's diffuse and fragmented tourism sector largely lacked the fiscal resources necessary for underwriting Strategy projects. Nor did the environmentalist and retiree constituencies from which the tourism proposal also drew support possess such resources. So instead of identifying sources of matching funds, Ward's proposal simply identified a list of government agencies and private foundations from which he planned to seek, through grants and other avenues, matching funding.

Ward's tourism proposal went through several transformations as a contest unfolded over selection of Klamath County's Regional Strategy. But the tourism proposal boosters never secured matching funds (Ward January 9, 1990; Various Unpublished Tourism Proposal Drafts). Recall that matching funds for many of the Jackson and Josephine County projects were provided by local government. But proponents of Klamath County's tourism proposal were denied similar local government backing since with the exception of Roger Hamilton, the County's local political establishment squarely supported the Light Industry proposal against which the tourism proposal would be competing. 


\section{Subterfuge and Coercion}

On July 24, 1987, John Ward addressed a letter to Jim Rogers, Chairman of the Klamath County Board of Commissioners. In his letter, Ward protested "an apparent Klamath County policy of discouraging citizen involvement and participation in developing an economic development strategy." The cause of Ward's consternation was the hearing Rogers had scheduled for July 29, to which Rogers had invited Team Klamath to present its Light Industry proposal. It appears that Rogers, in conjunction with fellow Commissioner Ted Lindow, planned this as the first of the two public hearings required under the terms of $\mathrm{HB} 3011$, the one at which they would target the Light Industry proposal as Klamath County's Strategy (Letter to Jim Rogers from John Ward dated July 24, 1987).

Ward (January 9, 1990; Herald and News August 2, 1987) saw the July 29 meeting as an attempted "fait accompli" by which Team Klamath and its supporters intended to adopt the Light Industry proposal in circumvention of those provisions of HB 3011 that first required evaluation of alternative strategies. Particularly vexing to Ward was the fact that with the exception of the legally required public notice placed in the Herald and News, the Klamath Falls' newspaper, no other announcement was made regarding plans to convene the July 29 meeting as the County's first Strategy hearing.

Continuing to register his concerns over Rogers' plans for the July 29 County Commission meeting, Ward concluded his letter by stating that he would "appreciate receiving notice that "the July 29 hearing Rogers had scheduled was not in fact...the first hearing of Governor Goldschmidt's Regional Economic Development Strategies." A copy of this letter was also sent to EDD. While the circumstances surrounding his decision to do so are not entirely certain, on the very night of the July 
29 meeting, Rogers changed the meeting's purpose from a first Strategy hearing, as he had originally intended, to an "information gathering" Herald and News August 2, 1987).

In a letter dated August 25, 1987, from the Klamath County Board of Commissioners, John Ward was advised as follows:

It has been brought to the attention of this board that the proposal that you submitted to the Commissioners contains material that is not true and accurate and was reprinted and copied out of context without the express written permission of the author. Therefore, it is the duty of the board to withdraw your proposal on tourism as a Klamath County Regional Strategy (Letter to John Ward from the Klamath County Board of Commissioners dated August 25, 1987).

Importantly, the letter was signed only by Rogers and Lindow, the two Light Industry proposal supporters on the County Commission, and not by Hamilton, Ward's ally in the tourism coalition, hinting at the polarization that would beset the Commission in the coming months.

After the "fait accompli" incident, Ward had been invited to present his tourism proposal at the Commissioner's meeting of August 19, 1987. In his presentation, he had used materials excerpted from a recent study conducted by the Pacific Power and Light Company. It was materials from this study to which the letter alluded. As it happened, PP\&L had authorized EDD to use the disputed material and it was EDD that in turn had provided the material to Ward. EDD's use of the material made it public record, making the accusations against Ward groundless. Other charges against Ward were demonstrated to be groundless as well. Commissioners Rogers and Lindow were consequently forced to acknowledge as much in correspondence dated September 8, 1987, in which they retracted their earlier letter, negating their prior withdrawal of the tourism proposal.

Also instructive is the series of letters OIT President and Team Klamath 
Chairman Larry Blake addressed to Ward warning him, in increasingly reproachful terms, against using college time to work on the tourism proposal. For example, in a letter dated October 12, 1987 Blake warned Ward:

you should stop immediately and make certain that any discussions, activities, or speeches in which you are involved regarding such tourism activities be totally on your own time, without use of college facilities or resources, and that you are clearly represented as an individual citizen and not as a representative of Oregon Institute of Technology (Letter to John Ward from Dr. Larry Blake dated October $12,1987)$.

As Ward's involvement with the tourism proposal increased, Blake's reproaches intensified, culminating in the winter of 1987 , about the time when as we shall see, the tourism proposal appeared to have emerged ascendant over that proposed by Team Klamath. Blake, who had already relieved Ward of his responsibilities as Director of the Small Business Development Center, issued an official reprimand of Ward for "default of academic integrity" and denied Ward a merit pay increase (Letter from John H. Smith to Thomas C. Howser, February 11, 1988). Responding to Blake's investigation, Ward's attorney inquired "President Blake has rather clearly violated the administrative rule relative to political activity...by speaking on behalf of the college, in favor of a purely local political matter. We are curious if any action is pending against President Blake?," before concluding "It is apparent that this is a political matter engendered by the opposing views of President Blake and Mr. Ward (Letter from Thomas C. Howser to John H. Smith, February 9, 1988). Ward's work on the tourism proposal was later vindicated when the grievance he filed with the state Board of Higher Education was upheld. Blake's reprimand being rescinded and the merit increase, reinstated.

In light of the seemingly groundless nature of the attacks Rogers, Lindow, and Blake pressed against Ward, these incidents can best be seen as attempts by Team 
Klamath's supporters to employ the powers of their offices to undermine Ward's work on a tourism proposal. Why would they have done so? Interviews in this matter proved inconclusive, but the most reasonable answer is that supporters of the Light Industry proposal viewed Ward's tourism proposal as a threat. Given the Governor's predilection for tourism strategies, Ward's proposal appeared likely to win his favor and thus preclude their effort to use Regional Strategies as a "stepping stone to Salt Caves." As the writer sees it, It was in an effort to preclude exactly such an eventuality that Rogers had attempted his aborted "fait accompli." Likewise, it was in an effort to undermine the competing tourism proposal that these officials launched their attacks on Ward. These attacks can be seen as an expression of the resolve with which Team Klamath intended to see its Light Industry proposal adopted as Klamath County's strategy.

\section{Tourism in Ascendancy}

When first asked to do so by the Governor, officials from Jackson, Josephine, and Klamath Counties had declined to commit themselves to implementation of a collective Strategy. Instead, each county set off to identify its own strategy with the understanding that when and if possible, the respective county strategies would be merged. However, it had become increasingly clear that the Governor would settle for nothing less than a collective tourism strategy in Southern Oregon. Recognizing this, officials from the above three counties as well as their counterparts in Curry and Lake counties had begun to meet informally as a group to lay the groundwork for a multicounty strategy compact. One such meeting was on September 16, 1987 in the coastal Curry County town of Brookings.

Almost universally, the Brookings meeting was described as something of a debacle. While not all the details are clear, this much is. Blake had assumed the role 
of chairman in the group's meetings. He traveled to Brookings by first flying into the airport in Cresent City, about twenty miles to the south, and then motoring to the meeting site in a limousine. His traveling partner was Bill Miller of Resource Management International (RMI), the Sacramento consulting firm that had been retained by the City of Klamath Falls to manage the Salt Caves project. It was RMI that chartered the flight and limousine which brought Blake to Brookings. Almost certainly, this means that his trip was financed by Salt Caves arbitrage funds (Ward January 9, 1990; Golden February 5, 1989).

Blake's travel plans seem to have evoked resentment from the other local officials, most of whom had endured a long and arduous drive to Brookings, which lies isolated from the rest of the state along a stretch of the southern Oregon coast. That he appears to have sought to use the meeting to promote Salt Caves seems to have further antagonized the other officials, so much that they subsequently voted to replace him as group chairman (Golden February 5, 1990; McGregor February 8, 1990).

At its September, 1987 meeting in Brookings, the group of local officials examining merger of the county strategies met under largely informal circumstances. In the meeting's aftermath, an effort was made to place the group's deliberations within a more formal framework. The result was formation of the Southern Oregon Regional Economic Development Strategies Steering Committee (SORS), composed of one commissioner from each of the constituent counties. It's unclear as to where the suggestion to arrange SORS in this manner originated, although EDD was almost certainly instrumental in this matter.

As the commissioner responsible for the County's economic development portfolio, it fell upon Roger Hamilton to represent Klamath County on the SORS 
steering committee. Appearing at the October 30,1987 meeting of the SORS panel, Hamilton announced that "he and the other Klamath County Commissioners had met and agreed that "tourism would be the strategy for Klamath County" and that Klamath County would join in implementing a common strategy with the other Southern Oregon Counties (Herald and News November 8, 1987).

Hamilton's pronouncement received the unequivocal endorsement of EDD, as illustrated in a letter written by George Wyatt, appointed head of the agency's Regional Strategies unit in August, 1987:

On Friday, October 30,1987, one commissioner from each of the six counties [including Klamath County] participating in the Southern Oregon Regional Strategy Committee met in Medford to discuss the regional strategies program and its applications in southern Oregon. It is the understanding of the Regional Strategies Unit that at this meeting the six commissioners present agreed to support a tourism strategy for the region. The Unit supports the concept of a regional tourism strategy (Letter to Southern Oregon Regional Strategy Committee Members from George Wyatt dated November 3, 1987).

Given the endorsement bestowed by EDD, Hamilton's announcement that Klamath County would be adopting a tourism strategy was treated as authoritative. So credible was Hamilton's pronouncement treated that Klamath Falls Herald and News reported as late as January 31,1988 , that "tourism has been selected by Southern Oregon county commissioners, including Klamath's, as the region's economic strategy."

\section{$\underline{\text { Revolt By Team Klamath }}$}

Despite the certitude with which Hamilton's pronouncement was received, his fellow County Commissioners were not, as Hamilton had stated, "unanimous" in their support for a tourism strategy. Commissioner Rogers intimated as much when he said, in the aftermath of the October 31,1987 SORS meeting, that "We [the board] have not adopted any kind of regional strategy at this time (Herald and News 
November 11, 1987). Accordingly Rogers, Lindow, and the other Team Klamath supporters were, as the November 5, 1987 edition of the Medford Mail Tribune described it, "confused" by Hamilton's pronouncement. In reality, Team Klamath remained as committed to making its Light Industry proposal Klamath County's strategy as it had been at the time of the aborted "fait accompli." Hamilton clearly knew this, for at the same time that he announced Klamath County's support for a tourism strategy, he conceded that the County's leaders "couldn't be more divided" over the issue and called the divisions "a legacy of Salt Caves" (Mail Tribune November 5, 1987).

In Team Klamath's view, the ascendancy tourism had seemingly come to enjoy as Klamath County's Strategy was largely attributable to the support bestowed by EDD. Consequently, during the autumn and winter of 1987, as tourism gained currency as Klamath County's Strategy, relations between Team Klamath and EDD deteriorated (Blake January 8, 1990; Lindow January 9, 1990).

Tensions between Team Klamath and EDD came to a head in December, 1987. Glancy traveled to Klamath Falls in an attempt to sway Team Klamath in support of the tourism proposal. She was unsuccessful in doing so. The meeting turned acrimonious, being marked by an especially heated exchange between Commissioner Lindow and Glancy, with the former accusing EDD of attempting to foist its will upon the community and the latter apparently telling the Team Klamath officials in no uncertain terms that she would approve no strategy for Klamath County other than one which adjoined the County to a multi-county tourism compact (Blake January 8, 1990; Lindow January 9, 1990; Wyatt February 13, 1990).

Recall that legislation passed during the spring of 1987 resulted in a significant expansion in EDD's responsibilities as well as in the size of the agency's 
staff. Lise Glancy was one of the newly hired staffers. Exactly what her professional background was is unclear, but she appears to have had little experience in either economic development planning or intergovernmental relations prior to her hiring. She was one of the former Goldschmidt campaign workers hired on during EDD's restructuring (Wetter November 2, 1989; Delman January 29, 1990).

Recall from the preceding chapter that in October, 1987, Glancy was quoted as saying ...Southern Oregon clearly is on the road to developing a coherent, apparently tourism-oriented strategy that will be ready for the Oregon Legislature when it convenes in 1989" (Mail Tribune October 23, 1987). Clearly, she recognized the Governor's plans to showcase the multi- county Southern Oregon region when attempting to sell legislators upon reauthorizing Regional Strategies. By all accounts, she demonstrated a strong conmitment to forging a multi-county tourism strategy in Southern Oregon, which included Klamath County. Her forcefulness in doing so fueled many of the tensions that prevailed between EDD and Team Klamath (Blake January 8, 1990; Lindow Janaury 8, 1990; Keller January 8, 1990).

\section{THE LOCAL ELITES PREVAIL}

Early 1988 found Hamilton and Ward collaborating with officials from the other SORS counties in planning a multi-county tourism compact. But both Rogers and Lindow remained inexorably opposed to a tourism strategy. While it would seem that between them, they had the votes to commit Klamath County to their favored Light Industry strategy, they did not do so, almost certainly in the knowledge that such a move would be blocked by the Governor. A stalemate prevailed and would continue to do so through at least April 6, 1988, when the Medford Mail Tribune reported that Klamath County's strategy was "still uncertain." 
It's unclear as to exactly when EDD decided to relent in its efforts to tie Klamath County into the multi-county Southern Oregon tourism compact and acquiesce to adoption of the Light Industry proposal as Klamath County's unilateral strategy. But a January 13, 1988 letter sent to EDD Director Reiten and endorsed by Commissioners Rogers and Lindow seems to mark a turning point. The letter requested that Klamath County be transferred from the jurisdiction of the Southern Oregon Regional Strategies coordinator to the agency's Coordinator for Eastern Oregon. The letter had been triggered by Team Klamath's disaffection with Glancy, which had reached the point at which she was no longer speaking to either Blake or Lindow (Blake January 8, 1990; Lindow January 9, 1990). But the letter can be seen as signalling a deeper purpose: it signalled Team Klamath's determination to sever the organizational tie which bound Klamath County to the other SORS counties. In effect, the letter served notice that under no circumstances would Klamath County's local government and business elites acquiesce in committing Klamath County to the Southern Oregon tourism compact.

In the aftermath of the letter, Glancy was replaced as Regional Strategies coordinator for Klamath County. Also in the letter's aftermath, EDD Director Reiten traveled to Klamath Falls where he met with Team Klamath. He was accompanied by Greg Satchell, who had replaced Glancy as Regional Strategies coordinator for Klamath County. According to Satchell (February 28, 1991), Reiten came away from his visit viewing OIT as the area's major economic development asset thus convinced of the propriety of a strategy which focused upon OIT as a "magnet" to attract industry to the area. Therefore he agreed to accept the Team Klamath proposal. But Team Klamath had been proposing its Light Industry concept since the summer, 1987; surely Reiten had plenty of time in the interim to recognize its propriety had he been 
so inclined. Instead, throughout this period, EDD had strongly backed a tourism strategy. For his part, Satchell tacitly admitted "The things they were doing were not the things a city the size of Klamath Falls should be doing," intimating that despite its having agreed to adoption of the Light Industry proposal, EDD was not really convinced of its propriety.

A more compelling explanation of EDD's change of heart is that Reiten returned from his visit to Klamath Falls convinced of the intractability of Team Klamath and its supporters including Lindow and especially Rogers, who had taken to calling a tourism strategy "a lot of hot air" (Mail Tribune April 6, 1988). Their intransigence appears to have paid off for on April 28, 1988, the Klamath County Board of Commissioners formally voted to adopt the Light Industry proposal as the County's Strategy, which was later officially approved by the Governor in February, 1988.

\section{Explaining Team Klamath's Success}

We've already seen how Goldschmidt wielded the discretionary authority provided him under the terms of HB 3011 to mold the other Southern Oregon counties into a collective tourism strategy compact. What explains the success with which officials in Klamath County were able to subvert his will?

Recall that participation in the Regional Strategies program was not mandatory. Instead Goldschmidt was counting upon the availability of lottery money to induce local participation. But Team Klamath had demonstrated a readiness to forego the lure of lottery money in the Bootstrap proposal. Their willingness to do so was brought on by their plans to spend the $\$ 50$ million in Salt Caves arbitrage funds, a figure that could only make the $\$ 550,000$ in lottery money they could expect from the Strategies look paltry by comparison. Viewed in this light, we can see Team Klamath 
as being insulated from the "carrot" element in the "carrot and stick" tactics characterized in the preceding chapter.

On the surface it would appear that Goldschmidt could have refused outright to approve any strategy that did not coincide with his wishes, as he seemingly threatened to do in Southern Oregon. As a practical matter however, he probably could not have done so without jeopardizing the likelihood that Regional Strategies would be reauthorized, since legislators had made clear, when inserting the "no seconds" rule into HB 3011, that they expected every county in the state to receive a share of the program's lottery allocation.

There was also State Senator Bernie Agrons intervention on behalf of Team Klamath. Agrons met with Reiten on the latter's visit to Klamath Falls. His position on Klamath County's strategy is perhaps best captured in a the following passage:

[The Light Industry proposal] is a far superior strategy to one that is based on tourism with the faint hope that tourists would turn into residents and employment creating entrepreneurs (Letter from Bernie Agrons to Klamath County Board of County Commissioners dated August 22, 1988).

Agrons sat on the legislature's T\&E committee and had been a prime backer of the "no seconds" rule, having said that no one could receive "seconds [of lottery funds] until everyone has had firsts" (Joint Legislative Committee on Trade and Economic Development February 18, 1987) and that every county had to have a "fair chance" at the lottery money (Joint Legislative Committee on Trade and Economic Development February 27, 1987). In addition, as a Democrat elected in a Senate District in which registered Republicans represented a majority of the electorate, Agrons was reputed to wield a lot of influence with other rural, as well as Republican legislators. It could not have been lost on Reiten and the Governor that an Agrons displeased with the outcome of Klamath County's strategy would be well positioned 
to threaten reauthorization of Regional Strategies.

Above we saw Team Klamath as being insulated from Goldschmidt's "carrot" tactics. We can see Agrons' intervention and the "no seconds" rule as circumventing the Governor's ability to use the threat of a strategy veto-- the "stick" in the parlance of the preceding chapter--to force Team Klamath to acquiesce to his will.

Then there was the question of timing. In October, 1987, EDD's Glancy had been quoted as saying "There comes a point where participants in the process want to come to closure" (Mail Tribune October 23, 1987). She seems to have been speaking as much for EDD as the local officials for although HB 3011 established July, 1989 as the deadline for approving strategies, the Governor almost certainly wanted all strategies approved by January, 1989, so they would, to again quote Glancy, "be ready for the legislature when it convenes" (Mail Tribune October 23, 1988), at which time the push to reauthorize the program would begin. Extending the dispute over Klamath County's Strategy not only threatened the likelihood that Klamath County would meet this deadline; it threatened to delay progress on the multi-county tourism strategy that had successfully been fashioned for the other counties since they could not properly proceed until Klamath County's status was settled.

\section{THE STATUS QUO STRATEGY}

Team Klamath's original Strategy proposal underwent something of a rhetorical transformation by the time it was presented in final form in December, 1988. Originally characterized as a Light Industry Strategy, it emerged in the end as a technology transfer strategy. 7 The change appears intended to highlight the instrumental role OIT was supposed to play in the strategy which, rhetoric aside, was otherwise little changed from when it was first unveiled during the summer of 1987. 
OIT was still to be the strategy's "magnet," attracting industry to the area while land surrounding the airport would be improved as an industrial park to accommodate relocating industries (EDD nd c).

As listed on Table VIII, the Strategy petitioned the Oregon State System of Higher Education (OSSHE) to establish, at a cost of $\$ 1.4$ million over four years, a Master of Science program at OIT. OSSHE had yet to do so at the time of this writing (June 1991), three years after the Klamath County strategy was adopted by the Governor, suggesting little efficacy in the Regional Strategies arrangement in this matter. Nor does it appear that OIT is likely to inaugurate a Masters program in the foreseeable future. In fact, voter approval of a statewide tax limitation measure in November, 1990 is certain to result in a severe reduction in OIT's budget, curtailment in the school's program offerings and hence, a reduction in OIT's capacity to serve in its envisioned "magnet" role.

The local match for construction of the building that would house the Oregon Technology Center--the small business incubator--was to be provided under the terms of a $\$ 500,000$ grant the city of Klamath Falls was seeking from the U.S. Department of Commerce's Economic Development Administration (EDA). However, subsequent to approval of the strategy, the city decided to redirect the grant to subsidize location of a pulp mill to Klamath Falls; scuttling the incubator project. 8 Later it was learned that the pulp mill would not be locating in Klamath Falls after all. EDA prohibited directing grant monies back to the incubator and in the end Klamath County neither availed itself of the EDA grant money nor built the incubator. However, EDD did allow Klamath County to use the lottery money initially allocated for the incubator to instead be used for improvements to OIT's Small Business Development Center (Satchell February 28, 1991; Keller January 8, 1990; Spencer January 8, 1990). 
TABLE VIII

KLAMATH COUNTY REGIONAL STRATEGY PROJECT LIST

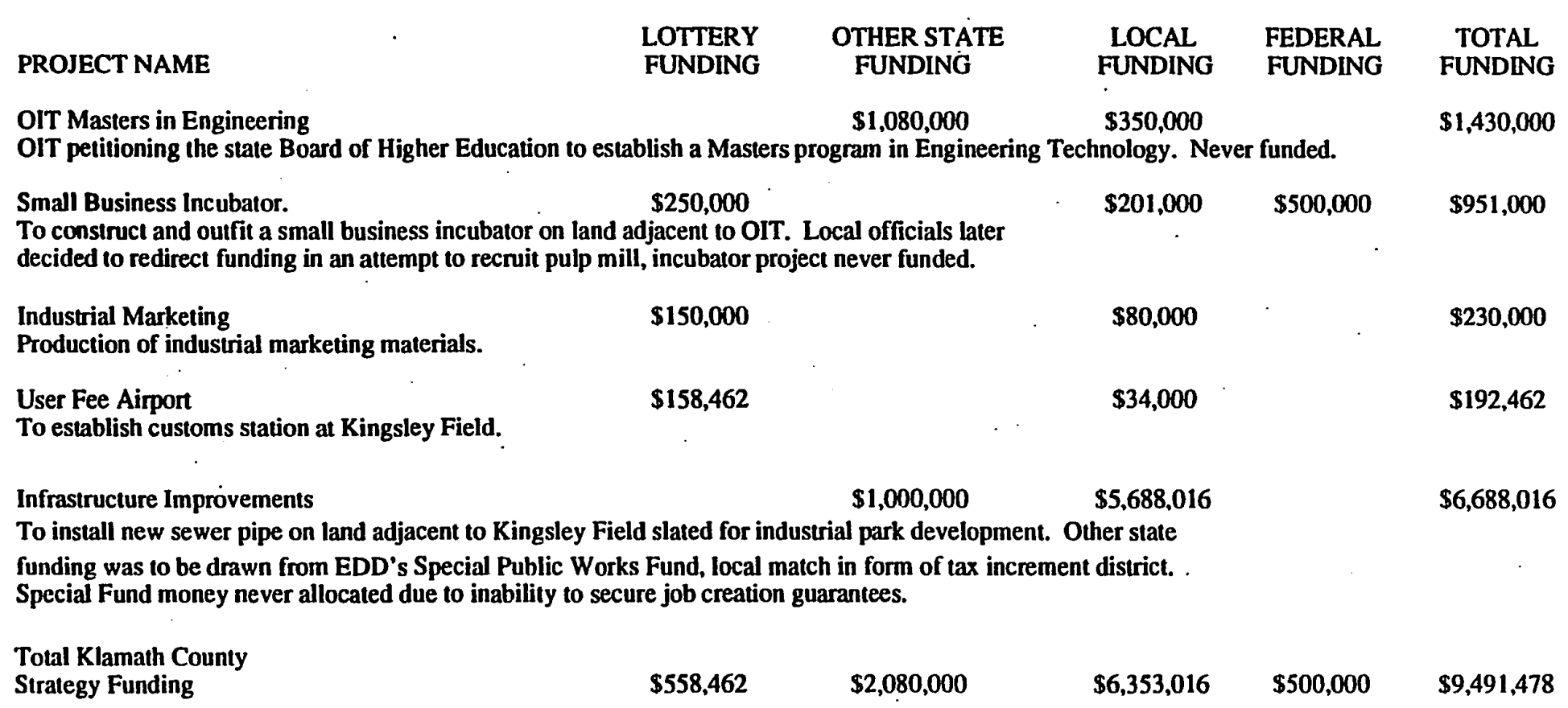

Source: Oregon Economic Development Department, nd. 
The Klamath County strategy also petitioned a \$1,000,000 grant from EDD's Special Public Works Fund (SPWF), a lottery funded program established at the same time as Regional Strategies, for use in making infrastructure improvements on the land that the city planned to develop as the airfield industrial park. Guidelines required evidence that at least one job would be created for every $\$ 20,000$ spent before any SPWF money could be dispensed. Lacking the private sector commitments necessary to create such jobs, local officials were unable to satisfy this criteria, nor have they been able to since. So at the time of this writing, none of the SPWF money requested in connection with the strategy had been released. According to EDD's Satchell (February 28, 1991), Klamath County is, however, free to cite this strategy provision in requesting SPWF monies should circumstances warrant such a request in the future.

Lottery dollars $(\$ 158,462)$ requested under the aegis of Regional strategies were used to pay for the cost of providing a user fee customs station for two years at Kingsley Field. Local officials hoped that the availability of customs service, coupled with OIT and other incentives they planned to offer, would attract industry to the airfield park. These other incentives included property tax abatements offered under the aegis of the city's enterprise zone, which overlayed the industrial park area, industrial revenue bonds, and membership in a Shared Foreign Sales Corporation, which provided a sort of duty free status for certain types of industrial assembly operations. To promote the availability of these incentives and attract investment to Klamath Falls, the strategy directed $\$ 150,000$ in lottery money towards an industrial marketing campaign to be managed, interestingly enough, by local officials. Thus, officials in Klamath County, in contrast to their counterparts in the other southern Oregon counties, appear to have succeeded in gaining direct discretionary control over state monies made available under the terms of Regional Strategies. 
Stripped away of rhetoric and aborted projects, what is left of the Klamath

County Strategy? The Strategy appears to be little more than a conventional industrial recruitment scheme. Interestingly enough, this Regional Strategies product appears as exactly the type of arrangement that characterized economic development policy under Governor Atiyeh, of which Goldschmidt had been so critical.

\section{SUMMARY}

Implementation of Regional Strategies in Klamath County became embroiled in conflict raging over plans to build the controversial Salt Caves dam. A growth coalition composed of local business and government elites sought to capture the Regional Strategies process as a vehicle for securing gubernatorial countenance of the dam. This mobilized a rival coalition composed of Salt Caves opponents behind a proposal to tie Klamath County to the multi-county tourism strategy being developed by neighboring Counties and favored by the Goldschmidt Administration.

In the end, it was a non-tourism proposal favored by the local growth coalition that emerged as Klamath County's Regional Strategy. The ability of the growth coalition to surmount the Administration's authority was attributable to the strong administrative capacity and fiscal and technical resources at its disposal, resources clearly in excess of those possessed by both neighboring Southern Oregon counties and the rival pro-tourism coalition, and the will of the growth coalition to assertively employ its capacity and resource advantages.

OIT's failure to receive authorization and funding for its sought after Master's program suggests limits upon the efficacy of the Regional Strategies arrangement to transform local demands into a policy response by the state apparatus and, commensurately, evidence of the failure of the Regional Strategies arrangement 
to coordinate the activities of the state apparatus. That abandonment of the small business incubator in an unsuccessful effort to recruit a pulp mill and failure to qualify for sought after Special Public Works Funds demonstrates the degree to which in a market economy, local economic development depends upon the vicissitudes of capital markets and the willingness of capitalists to invest in the local community. In the final analysis, Klamath County's strategy can be seen as the type of industrial recruiting arrangement that had fueled so much conflict when made the centerpiece of economic development policy under the Atiyeh Administration, and which Governor Goldschmidt had intended regional strategies to serve as an alternative to. 


\section{NOTES}

1. This is a small hydro-power dam as dams go. For comparison, the Columbia River's Bonneville Dam has a rated capacity of over 1,000 megawatts.

2. Mention of Blake's recommendation was made in an earlier chapter. It amounted to using lottery money to establish local economic development offices responsible for developing local economic development plans.

3. Under federal law, the city could spend these arbitrage funds for a period of five years after which time these funds needed to be earmarked to retire the principal and interest on the bonds. Welcome Center appears to have been included in the proposal only to make it more palatable to the Governor who, as Team Klamath knew, had expressed his preference for

4. There do not appear to be any polls available with which to gauge the degree of local support for the dam so an exact assessment of how pervasive this opposition was is not available. One local source (who was admittedly opposed to the dam) put the figure at 80 percent favoring dam construction and 20 percent opposed.

5. The Special Public Works Fund was a new program established by Goldschmidt in 1987 concomitant with Regional Strategies and his reorganization of the state Economic Development Department. It reserved lottery money for public facilities improvements linked to new industrial development.

6. These were the Klamath Visitors and Convention Bureau, the Klamath County Lodging Industry Association, the Oregon 58 Cascade Summit Recreation Association, and the Visitor Industry Association of Klamath Rivers.

7.The exact title of the Klamath County Strategy was "Technology Transfer: Jobs for the 90's...and Beyond." 


\section{CHAPTER DX}

\section{CONCLUSION}

This dissertation set out to identify the variables that determined the amount of autonomy state leaders possessed in formulating and implementing the Regional Strategies program, centerpiece of industrial policy in Oregon during the latter half of the 1980s under the Administration of Governor Neil Goldschmidt. In this chapter, I present my conclusions.

\section{RECAPITULATION ON STATE AUTONOMY}

The concept of state autonomy is founded upon the theory that state leaders have interests apart from those of non-state groups and that state leaders embody their interests in the programmatic arrangements that define their public policy interventions. The literature on state autonomy points principally to two such interests: the provision of public goods and the desire to maximize tenure in public office.

Because state autonomy is subject to constraints, state leaders never act wholly autonomously; instead, they possess relative autonomy. Four key constraints upon autonomy are hypothesized: the control private capitalists possess over the investment capital upon which the provision of public goods depends, limitations upon the ability of state leaders to acquire and process information, limitations on the ability of state leaders to get individuals and the complex bureaucratic organizations to act as state leaders want them to act, and limitations originating in the division of powers between different branches of government. Theory also posits that state autonomy is 
likely to be enhanced under crisis conditions, when existing policy arrangements break down.

The degree to which state leaders can act autonomously in pursuit of their interests is largely contingent upon the fiscal and administrative capacity of the bureaucratic apparatus over which they preside. State leaders are more likely to transform their interests into authoritative actions if they are able to exercise discretion over available fiscal resources, as opposed to having their control limited by their dedication for specific uses. Similarly, state leaders are more likely to be able to secure their goals if the groups whose behavior they are hoping to influence through their policy interventions are fiscally dependent upon state revenues under their control. To the degree that state leaders control of the complex organizations involved in policy delivery, they are likewise more likely to translate their policy preferences into authoritative actions.

\section{EVALUATING THE POSTULATES}

At the outset of this dissertation, I posited six indicators of state autonomy. I now examine each of these propositions to evaluate the degree to which the events that characterized formulation and implementation of Regional Strategies are indicative of state autonomy.

The Initial Impulse to Industrial Policy will be Provided by Forces Arising Within State Government and not Private Groups

Theory posits that autonomous state leaders can initiate policy activity independent of private non-state groups. The analysis offered here offers only conditional support for this postulate. In Oregon, the precepts of industrial policy were first articulated not by political leaders but by private labor and business groups. 
The role state actors played in bring industrial policy to Oregon was less one of originator of new policy ideas than one of seizing upon and mobilizing political support for principles first articulated by private sector constituencies and then molding these principles into a set of programmatic guidelines.

The first half of the 1980s was a period of economic crisis in Oregon. Restructuring in the wood products sector, aggravating economic bifurcation between the diversified economy of Oregon's most highly developed area, the Portland metropolitan region, and Oregon's less developed, heavily wood products dependent and largely rural regions. The Atiyeh Administration's attempt to deal with Oregon's economic crisis through a program of industrial recruitment failed because of its failure to reconcile regionally divergent economic development policy aims. Disaffection with industrial recruitment fueled calls for state economic development reform. Reform proposals incorporating important industrial policy principles, including sectoral targeting and the elimination of fragmentation in state government were articulated by non-state constituencies. These were Oregon's AFL-CIO, strongly rooted in Oregon's lesser developed timber dependent regions, and Portland City Club, which articulated in large part the views of the Portland area's business establishment. The AFL-CIO articulated its proposal for state economic development reform in mid-1982. The City Club's proposal was articulated in late 1983. Yet, Oregon's badly divided political leadership proved unable to translate these calls for economic development policy reform into practice.

It was not until 1987, with the inception of the Regional Strategies program, that the industrial policy principles articulated in Oregon by the AFL-CIO and City Club assumed a prominent position on the state's economic development agenda. The Goldschmidt Administration embraced industrial policy as a vehicle for promoting 
economic restructuirng in Oregon's less developed regions and ending the conflicts that surrounded the Atiyeh Administration's industrial recruitment effort. More immediately, however, the Goldschmidt Administration embraced industrial policy as a vehicle for fashioning an electoral coalition between groups which, divided by other differences, nonetheless shared a common interest in industrial policy reform and thus, securing the electoral support necessary to assuming public office. Subsequently, the Goldschmidt Administration seized upon its electoral mandate to install the Regional Strategies program as the centerpiece of state economic development policy in Oregon.

State Industrial Policy will Embody Goals Peculiar to State Leaders and Apart from those of Private Non-state Groups

Theory posits that leaders of the autonomous state will embody in their policy initiatives goals independent of those of private groups. Two principal goals are theorized. These are the provision of public goods and the maximization of tenure in public office. This analysis depicts the Goldschmidt Administration as having embodied within its Regional Strategies intervention both of these key interests which, when embodied in public policy interventions, are indicative of state autonomy.

The Goldschmidt Administration behaved in a manner consistent with this postulate. The Administration's embrace of industrial policy was driven by two principal objectives. One was to induce economic restructuring in those lesser developed regions of Oregon lacking intrinsic attractions for capital. Through its economic restructuring efforts, the Goldschmidt administration aimed to create jobs, boosting the vitality of declining communities and generating tax revenues necessary for the provision of public services. Put another way, through industrial policy, the Administration aimed specifically to provide one public good--economic 
development, a socially beneficial service which the private sector was unwilling to provide of its own accord--while commensurately enhancing the state's ability to provide other public goods as well.

Political exigencies were also behind the Goldschmidt Administration's embrace of industrial policy. The Goldschmidt campaign embraced a platform promising state economic development reform along industrial policy lines as a vehicle for recruiting electoral support. Once in office, the Goldschmidt Administration viewed Regional Strategies as a vehicle for perpetuating its tenure in office.

State Leaders will Demonstrate an Ability to Override Opposition to their Industrial Policy Interventions

Autonomous state leaders will be able to override opposition to their industrial policy activities by private non-state groups in seeking to secure their goals. What does this analysis have to say about the Goldschmidt Administration's ability to override opposition to its industrial policy goals? Opposition to the Goldschmidt Administration's industrial policy goals was expressed in sectional terms--economic interests expressed along territorial lines. The local groups with which the Administration dealt in overseeing implementation of Regional Strategies were territorial based and concerned with extracting lottery money and other benefits from the state.

This analysis identified two avenues of local involvement in Regional Strategies. In Central Oregon and Klamath County, powerful growth coalitions captured control of the Regional Strategies implementation process. They were able to do so due to the capacities for planning and mobilizing for economic development they possessed. In contrast, no dominant growth coalitions emerged in Southern 
Oregon. In Southern Oregon, implementation of Regional Strategies was characterized by maneuverings among diffuse and fragmented groups, none of which proved ascendant.

More so than anything else, the Goldschmidt Administration's dealings with local groups revolved around its efforts to see multi-county tourism strategies implemented. In Central Oregon, the Goldschmidt Administration's preference for seeing multi-county tourism strategies implemented converged with the interest of the local growth coalition. Central Oregon's multi-county tourism strategy was the product of an accommodation between Central Oregon's pro-tourism growth coalition and the Goldschmidt Administration.

Southern Oregon also implemented a multi-county tourism strategy. But the nature of the arrangement that prevailed between the Goldschmnidt Administration and local groups in Southern Oregon was far different. No powerful growth coalition emerged in Southern Oregon, where diffuse and fragmented groups instead prevailed. Rather than being the product of an accommodation, the multi-county tourism strategy implemented in Southern Oregon was the product of local acquiescence to a Goldschmidt Administration dictum.

Last, there is the case of Klamath County where, as in Central Oregon, a powerful growth coalition emerged to capture control of the strategy implementation process. Unlike Central Oregon, however, Klamath County's growth coalition aimed to use the strategy process to pursue goals in contravention of the Goldschmidt Administration's preference for multi-county tourism strategies. And in the end, of course, the Regional Strategy implemented in Klamath County embodied not the Administration's goals but those of the local growth coalition.

Did the Goldschmidt Administration successfully override sectionalism in its Regional Strategies intervention? There is no simple yes-or-no answer. Where 
sectionalism was manifest in weak and fragmented terms and sectional constituencies sought to extract benefits from the Administration, Southern Oregon being the prime example, the Administration demonstrated an ability to use the discretionary authority it enjoyed over state lottery spending to override sectional constituencies and attain its goals. Where sectionalism was expressed through more powerful entities, however, the Administration's record in securing its goals was more ambiguous. The Administration succeeded when it reached accommodation with the powerful Central Oregon growth coalition whose agendas was closely aligned with the Administration's. On the other hand, the Administration failed to override opposition when confronted with a largely self-sufficient local growth coalition whose preferences diverged from its own, as in the case of Klamath County.

The Programmatic Choices that Shape Industrial Policy will be Based Upon Objective Analysis

Effective information collection and processing is central to the capacity of state leaders to formulate and pursue goals apart from those of private groups. HB 3011 called for the de-politicization of policy choice. It directed counties to base their strategy selections upon an analysis of the "specific economic opportunities and liabilities [and] unique resources in the region that might be marshaled in support of a regional strategy." Counties were supposed to select the one with the greatest potential for creating family wage jobs, a term which HB 3011 defined with precision. By this provision of HB 3011, the architects of the Regional Strategies program appear to have aimed to place the strategy selection process upon an objective footing.

Yet, as regards strategy selection, the Goldschmidt Administration was not without preference. Ample evidence of its proclivity for tourism strategies has been presented. Administration officials asserted that their preference for tourism strategy 
was based upon economic analysis that showed that promoting tourism could fuel rapid job growth in Oregon. Independent analysis presented herein supported the view of tourism as a potentially high growth industry and has been construed as lending support to the assertion that the Goldschmidt Administration's proclivity for tourism promotion as an economic development strategy was indeed analytically defensible. This does not tell the whole story, however. For when it came to implementing Regional Strategies, practice diverged from design.

More than anything else, it was over the issue of strategy selection that the accommodations and disputes that defined implementation of Regional Strategies unfolded. Strategy selection was less a product of objectively assessing the relative merits of different strategy options than a product of political maneuvering, expediency, and efforts aimed at ensuring equity. The analysis presented here pointed to three impulses to the role these concerns assumed in the strategy selection process.

One was the Goldschmidt Administration's goal of using Regional Strategies as a vehicle for perpetuating its tenure in public office. Analysis of the Southern Oregon strategy helps make this point. It would be hard to argue that the decision to implement a tourism strategy in Southern Oregon was a function of objectively selecting from among various strategy options that which offered the greatest benefits versus costs. The evidence is to the contrary. For whatever tourism's prospects for generating jobs, little evidence was presented that promoting tourism could do so in Southern Oregon. Instead, Southern Oregon's decision to implement a tourism strategy amounted to acquiescence to an Administration dictate. The forcefulness and expeditiousness with which the Administration acted to impose a multi-county strategy upon Southern Oregon was driven in part by the importance it attached to demonstrating the efficacy of the Regional Strategies arrangement within the short 
window afforded by the legislature's schedule if an effective case was to be made for program reauthorization. The impulse to the implementation of a multi-county tourism strategy in Southern Oregon was in short, political, not economic.

There is something contradictory about the Administration's actions in Southern Oregon. It drafted a rigorous set of principles to guide strategy selection but then abandoned these principles in the name of political expediency. This should not be surprising, however. For when state leaders deliberately aim to depoliticize policy choice as a vehicle for pursuing the self-serving goal of political self-perpetuation, they are making a policy decision that is driven de-facto by political calculations. Under such circumstances, policy choice cannot be properly said to have been depoliticized.

In formulating and overseeing implementation of Regional Strategies, the Goldschmidt Administration did not operate in a vacuum but in an environment in which other groups were active as well. The two most important were the state legislature and local growth coalitions. Because legislators had to authorize and fund Regional Strategies, politics mattered. The Goldschmidt Administration's selection of Central Oregon as a Regional Strategies prototype was driven in part by its desire to secure legislative endorsement of Regional Strategies while Central Oregon was picked as a prototype to offset rural disgruntlement over the Administration's endorsement of Portland's Convention Center and due to the position key lawmakers from Central Oregon occupied on the T\&E Committee. Seen in this light, the Administration's selection of Central Oregon as a prototype appears to have been based primarily upon political calculations.

Lawmakers agreed to endorse Regional Strategies but in doing so, placed limitations upon the discretion the Administration hoped to exercise. As regards 
policy choice, two limitations are of particular interest: the Sunset Clause and noseconds rule. In the Sunset Clause and no-seconds rule, we see evidence of what Gurr and King (1987) have termed "political limitations" upon the autonomy of state leaders--limitations arising out of the division of power between different branches of American government.

Neither the Sunset Clause nor the no-seconds rule had much to do with objective calculations of how Oregon's resources might best be tapped to promote economic restructuring. It was likely that economic restructuring would take several iterations of Regional Strategies intervention. Nonetheless, legislative reluctance to cede the Administration too much authority led to the insertion of the Sunset Clause into HB 3011. The Administration opposed the no-seconds clause because it wanted to be able to competitively evaluate and prioritize local strategy proposals, funding for implementation those most promising. This was unacceptable to lawmakers, however, who wished to ensure that every area of the state received a share of the Regional Strategies appropriation. As with the Sunset Clause, it was politics, not objective calculations of how best to promote economic restructuring that led to the insertion of the no-seconds rule into HB 3011.

These limitations impaired the Administration's ability to secure key industrial policy goals. The Sunset Clause drove the Administration to emphasize expeditiousness in implementing Regional Strategies in Southern Oregon and Klamath County which so as to bolster the case for reauthorizing Regional Strategies. The noseconds rule placed the Administration in a position of having to approve Strategy funding for every area of the state regardless of the relative merits of local strategy proposals. Put another way, the likely effect of no-seconds was to preclude competitive evaluation of strategies and instead make equity a driving force behind the 
award of strategy dollars. Absent the Sunset and no-seconds clauses, Southern

Oregon's might have been deferred until more concrete restructuring plans could have been drawn up beyond those which to a large degree, amounted to simply using state dollars to subsidize local public works projects.

The role local growth coalitions played in implementing Regional Strategies points to the third factor that led to the subordination of objective concerns in the strategy selection process. In both Central Oregon and Klamath County, implementation of Regional Strategies was captured by powerful local growth coalitions. Coalesced around preordained economic development agendas--the promotion of tourism in Central Oregon and the building of the Salt Caves dam in Klamath County, they used the control they exercised over the strategy implementation process to further their agendas. The Central Oregon and Klamath County growth coalitions showed little inclination to engage in the type of economic analysis called for in HB 3011 or even, more tellingly, to acknowledge competing ideas. Probably nothing illustrates this point better than the extremes Team Klamath went to in promoting tourism as Klamath County's strategy.

Were the decisions that shaped the Regional Strategies program primarily a function of objective analysis? On balance, the answer would appear to be no. While there was an expressed intent to place policy choice on objective grounds by the Goldschmidt Administration, in practice, objective analysis was subordinated to pressures emanating from a number of sources. These included the emphasis the Administration placed upon seeing the Regional Strategies program authorized and reauthorized, legislative resistance to having its authority encroached upon by the Administration, lawmaker demands for equal division of state lottery money, and the power of local growth coalitions. Thus, the policy choices that defined the Regional 
Strategies program were guided not by economics but political expediency and sectionalism.

State Leaders Will Target Their Industrial Policy Interventions Upon Emerging Sectors of the Economy

Perhaps no feature of this analysis is as inescapable as the Goldschmidt Administration's predisposition towards the implementation of tourism strategies. The Administration viewed tourism as a recession resistant industry likely to fuel rapid job growth. It viewed tourism not only as a vehicle for generating jobs but "as a hook" for visitors who might later return permanently to live and work in Oregon's less developed regions.

In their study of recreational spending in rural Georgia, Bergstrom et al. (1990) found that recreational spending not unlike that undertaken under the aegis of the Southern Oregon Regional Strategy fueled large employment multipliers. Bergstrom's findings can be viewed as endorsing the Goldschmidt Administration's view that tourism could play a key role in fueling economic restructuring in Oregon's less developed regions. Still, there is no certainty that the implementation of regional tourism strategies would induce capital investment. In at least one case, in fact, Regional Strategies failed to induce such investment, this being the failure of investors to carry through on their announced plans for expanding Josephine County's Paradise Ranch resort. Medium and large sized firms typically employ site location consultants in making business location decisions and are thus unlikely to establish business facilities in Oregon on the basis of recreational visits to the area (Schmenner 1984). These firms were unlikely to invest in rural Oregon on the basis of recreational visits. This analysis failed to corroborate the Goldschmidt Administration's claims that tourism is an anti cyclical industry which "continues to create jobs whether other parts 
of the economy rise or fall." There is, in fact, at least one reason to believe that Oregon's tourism sector is highly prone to volatility. This pertains to the heavy dependence of Oregon's tourism sector upon visitors from Californian's travelling by car. In 1979, for example, fully 40 percent of Southern Oregon's tourism trade was attributable to Californians travelling by car (Oregonian July 18, 1979). The 1979 oil crisis severely curtailed auto travel in the U.S. This turned out to be costly for Southern Oregon; the reduction in vehicular traffic that arose from the 1979 energy crisis cost Southern Oregon $\$ 200$ million in tourism revenues (Oregon Journal July 17, 1979). This was not the first time Southern Oregon's fortunes suffered as the result of an energy crisis. The period following the 1973 Arab oil embargo saw visitor traffic at Southern Oregon's Crater Lake Park decline by 15 percent. At the Oregon Caves National Monument in Josephine County, the figure was 11.4 percent (Oregonian November 21, 1973). As events of 1990 demonstrated, gasoline crises are far from a thing of the past. Environmental and geopolitical considerations ensure future recurrences. If tourism holds forth the promise of fueling rapid job growth, it may nonetheless prove to be an unpredictable and unreliable path to restructuring local economies in Oregon's less developed regions.

Then there is the issue of tourism industry incomes. According to the Oregon Employment Division, a mere 15 percent of jobs created from the implementation of tourism strategies in Central and Southern Oregon were likely to exceed the family wage standards established in the Regional Strategies program's founding legislation. Many tourism jobs are part-time and seasonal. The architects of Central Oregon's tourism strategy argued, citing a figure of $\$ 4$ per hour for a tourism related job, that the low wages associated with tourism should nonetheless not comprise a barrier to the implementation of tourism strategies because of the "reality of the two earner 
family." The conclusion reached herein was that if implementing tourism strategies held forth the likelihood of fueling rapid job growth, it was likely to be job growth built upon a marginalized, low wage work force.

It's also instructive to recall Southern Oregon's penchant for retirement living. Many of the retirees that settled in Southern Oregon were attracted to the area by its recreational amenities. Also, adoption of a tourism strategy found favor with elements of Josephine County's retirement community. This raises the likelihood that promoting tourism strategies might lead to additional retiree relocations to Southern Oregon, or other regions promoting tourism strategies. Such an outcome would, in fact, appear consistent with the Goldschmidt Administration's aim of using tourism as a hook. Yet, retirement communities typically have low average incomes, poor housing and high taxes. Also, as the population of senior citizens rises in a community, the community's costs for medical care and social services are likely to rise (Fitzpatrick and Logan 1985). This raises the prospect of fiscal crisis for communities with heavy concentrations of senior citizens, especially if future changes in federal Medicare and social security entitlements increase the cost of providing health care to seniors incurred by local and state government.

State Industrial Policy is Characterized by Concerted Action Amongst the Economic Development Agencies of State Government

The Goldschmidt Administration inherited a fragmented state government apparatus when it took office. Governor Goldschmidt believed that successful economic restructuring required that Oregon's capacity for economic development be increased. He envisaged Regional Strategies as a vehicle for coordinating the activities of state agencies involved in implementing his industrial policy program. The Administration's initial plan called for subordinating key quasi-autonomous state 
commissions to the Governor's authority. Doing so could have increased coordination among the state agencies over which these commissions presided. The Administration's plan was frustrated, however, by legislators reluctant to place too much authority in the hands of Oregon's governor.

Denied the authority it sought over Oregon's semi-autonomous commissions, the Goldschmidt Administration was instead provided with a loosely defined mandate for state agency coordination revolving around EDD's role in negotiating the compliance of other state agencies with demands channeled through local strategy project lists. This arrangement did secure Curry County the right- of-way local officials were seeking from the state highway department and provide Josephine County access it was seeking to a highway department kiosk. But these were administrative matters of relatively minor consequence. There is little indication that the arrangement HB 3011 established for coordinating state agency involvement in Regional Strategies proved efficacious in delivering complex and costly strategy projects. The role EDD assumed in seeking to secure Southern Oregon's "highest regional priority," the improvements to Highway 140 , produced little more than rhetoric. Repudiating EDD's mediatory effort, state highway department planners refused to depart from their well institutionalized six year capital planning process. Klamath County failure to use Regional Strategies to secure authorization and funding for a graduate program at OIT provides another case in point.

Standing apart from these failures are the two instances in which the Goldschmidt Administration succeeded in centralizing and concentrating state economic development activity. These were Central Oregon's highway improvements and Southern Oregon's multi-county tourism marketing campaign. Instructively, however, neither project was secured through conventional channels of authority. By 
all indications, the Central Oregon highway improvements were constructed at the behest of Mike Hollern, the Bend area developer and Goldschmidt campaign supporter installed as head of the state transportation commission and not through ODOT's routine capital improvements planning process. Implementation of the Southern Oregon Strategy similarly saw the Administration sidestep conventional channels of authority, this time to boost and concentrate state tourism marketing activities.

Central Oregon's highway improvements, the Southern Oregon tourism marketing campaign and the improvements Southern Oregon sought for Highway 140 were all complex and costly projects. Efforts to secure these projects produced divergent outcomes. The first two were secured, the last, not. The key distinction between these projects appears to be the degree to which they were valued by the Goldschmidt Administration and commensurately, the degree to which the Administration acted to circumvent conventional channels of administrative authority. The Goldschmidt Administration unequivocally endorsed both Central Oregon's highway improvements and the tourism marketing campaign. Governor Goldschmidt gave his personal endorsement to Central Oregon's highway improvements when he met with the Committee of Seven in January, 1987. The importance the Administration attached to the tourism marketing campaign was attested to by Debbie Kennedy, the Goldschmidt protege made head of EDD's tourism division. There is, in contrast, little to indicate that Governor Goldschmidt viewed improvements to Southern Oregon's Highway 140 as a priority. In turn, the Administration went to extraordinary lengths to secure the projects it valued, circumventing established channels of authority. In contrast, the Administration demonstrated little interest in circumventing established channels for the Highway 140 improvements, not an Administration priority. 
What can we say about the extent to which Regional Strategies served as a vehicle for coordinating the activities of state agencies involved in implementing industrial policy? Goldschmidt Administration plans for consolidating control over the state apparatus were stopped by the legislature. Only when the Administration resorted to routines outside the established administrative order that success in concentrating and coordinating state authority was evinced most clearly.

\section{THE AUTONOMY VARIABLES}

How much autonomy did the Goldschmidt Administration possess in formulating and implementing Regional Strategies? There is no,easy answer to this question. While the Administration demonstrated an ability to independently formulate and secure sought after industrial policy goals in some cases, in others, the Administration was frustrated in its ability to translate its policy preferences into authoritative actions. Gubernatorial success varied with place and time and with the constellation of actors involved in the policy process. The behavior evinced is indicative of relative autonomy--the condition that exists when constraints limit the capacity of state leaders to independently formulate and secure policy goals.

The amount of relative state autonomy evinced in the formulation and implementation of Oregon's Regional Strategies industrial policy program was affected by several variables. I identify these variables and situations below.

\section{Economic Crisis}

The literature points to economic crisis as a variable in determining the amount of relative autonomy possessed by state leaders. This analysis points to economic crisis as a driving force behind Oregon's transformation during the 1980s from a state evincing little autonomy in economic development policy to a state 
evincing more autonomy under industrial policy. Oregon began the 1980 s with industrial recruitment as the centerpiece of state economic development policy. Embodying the goals of Portland area business elites and a fragmented implementation regime, industrial recruitment was indicative of a state possessing little autonomy. Economic crisis during the early 1980s provided the impulse to Oregon's shift away from industrial recruitment. The failure of industrial recruitment to resolve Oregon's economic crisis led important constituencies to repudiate it, opening the door for industrial policy. New political leadership embraced industrial policy both as a vehicle for providing economic development--a public good--as well as for securing political advantages in a struggle with competing political forces. Popular demands for state economic development reform allowed the Goldschmidt Administration to secure extraordinary authority over state lottery spending, the principal instrument employed by the Administration to attain its goals.

\section{Division of Powers}

The division of powers between the executive and legislative branches of American government is a variable in the amount of autonomy state leaders possess in their public policy interventions. We've seen this come into play in the formulation and implementation of industrial policy in Oregon.

Crisis gave Oregon's chief executive a mandate to reshape state economic development policy along industrial policy lines. However, the extent to which Oregon's executive branch could effectively pursue its industrial policy goals was contingent upon authority granted by the state legislature. At the same time lawmakers provided Oregon's chief executive with extraordinary authority useful for securing certain of its key goals, it circumscribed executive capacity for securing other goals. Responding to the crisis, lawmakers provided Oregon's chief executive with 
extraordinary authority over state spending. By the same measure, tensions founded in localism, regionalism, and concern with having its authority usurped led lawmakers to impose the Sunset Clause and no-seconds rule upon executive branch actors, which variously alter certain executive branch goals and obviated instruments the state executive aimed to rely upon in attaining other key goals.

\section{Fiscal Capacity}

State leaders must possess sufficient fiscal resources if they are to secure their public policy goals. This analysis points to increased state fiscal capacity as a key determinant of the amount of state autonomy evinced in the formulation and implementation of industrial policy in Oregon.

Oregon was a fiscally weak state throughout the first half of the 1980 s. The principal source of state economic development funding was industrial revenue bonding, which allowed little discretionary control. As revenue bonds, IRB's comprised a dedicated source of state funding. Establishment of the state lottery provided Oregon's political leadership with a funding source over which it could exercise discretionary authority and expanded the state's economic development role.

\section{Local Dependence}

State leaders are more likely to secure their public policy goals if they can exercise discretionary control over the spending of state funds. The possession of state autonomy varies with the degree to which local interests are dependent upon state leaders for revenues. State leaders are more likely to secure their goals in circumstances in which local interests are fiscally dependent upon them for revenues than in instances in which local interests are financially independent of the state. This becomes clear when comparing the ability of Oregon's state leadership to secure its 
programmatic goals in the different regions. In Southern Oregon, fragmented and fiscally weak groups were dependent upon revenues controlled by Oregon's state leadership. State leaders were therefore able to extract concessions that enabled them to realize their aims of implementing a multi-county tourism strategy. The Southern Oregon experience stands in sharp contrast to the case of Klamath County, where implementation of Regional Strategies was dominated by a powerful growth coalition possessing fiscal resources sufficient to allow it to repudiate the revenues offered by Oregon's state leadership and commensurately, to curtail the ability of Oregon's state leadership to secure its goals.

\section{The Character of Private Capital Investment}

The amount of autonomy possessed by state leaders is contingent upon the willingness of private non-state actors to invest the capital upon which economic development depends. Through industrial policy, Oregon aimed to promote economic restructuring in areas lacking an inherent attraction for capital. While this analysis has not aimed to measure the extent to which Oregon's industrial policy initiative actually resulted in economic development, it does raise questions as to Oregon's ability to induce capital investment. For example, despite Oregon's industrial policy initiative, investment promised for Josephine County's Paradise Ranch resort failed to materialize. Furthermore, to the degree that the industrial policy activities portrayed herein induced private investment in Oregon's tourism sector, restructuring was likely to be built largely upon a low wage, marginalized work force and perhaps to increase communal propensity for future economic crisis. In sum, Oregon had little control over the character of private investment necessary to goal attainment. Oregon's reliance upon private actors for the investment capital upon which economic 
development depended points to a limit upon Oregon's ability to secure its economic restructuring goals.

\section{ENTREPRENEURIAL POLITICS}

The Goldschmidt Administration's efforts to overcome limits upon its autonomy produced a highly entrepreneurial form of politics in which the Administration endeavored to reorder the political environment within which it operated. The concept of entrepreneurial politics has received attention from Frohlich, Oppenheimer, and Young (1971). In the widest sense, an entrepreneur is a political leader who deliberately molds policy so as to respond to social problems and at the same time, to create beholden political constituencies with which to promote the leader's own future political aspirations. It is the merging of personal political and practical concerns within policy that is the hallmark of a political entrepreneur.

For present purposes, the most useful characterization of entrepreneurial politics is offered in Mollenkopf's (1983) analysis of the politics of urban redevelopment. Mollenkopf argued for a view of urban constituencies which although inherently divided by divergent economic interests, shared a common interest in redevelopment. Left to their own devices, the disparities dividing these constituencies precluded cooperation, with the result that no single constituency was able to control the mechanics of the redevelopment process and hence, no redevelopment took place. In Mollenkopf's view, successful redevelopment depended upon the ability of political entrepreneurs to overcome these divisions and forge coalitions. The entrepreneur did so by gathering and risking:

political capital and support in order to reshape politics and create new sources of power by establishing new programs. The entrepreneur does not simply play by the rules of the game, but attempts to win the game by changing the rules. Using government to create beneficiary 
groups, political entrepreneurs create supportive new constituencies (Mollenkopf 1983).

Mollenkopf's characterization of entrepreneurial politics fits the Goldschmidt Administration's role in formulating and implementing Regional Strategies.

Oregonians perceived a collective interest in economic development, evidenced by voter approval of the state lottery. But prior to the Goldschmidt Administration's installation in office, the unwillingness of the state's highly divided constituencies to cooperate and a fragmented institutional structure impeded an economic development planning effort of the scope necessary to serve their common interests. Through Regional Strategies, Governor Goldschmidt set out to reorder this environment by forging consensus and concentrating state resources. Doing so required that existing power relationships be eliminated or circumvented. Toward this end, he created an new industrial policy arrangement different from that of his predecessor, Governor Atiyeh. He restructured EDD in an attempt to its power and consequently, gubernatorial authority, over the fragmented state apparatus. Success required the breaking of local power relationships that impeded economic restructuring. The best example was the Goldschmidt Administration's unsuccessful attempt to break the hold Klamath County elites had over local economic development by forcing them to accede to a regional tourism strategy.

It is not surprising that these examples of entrepreneurial politics provided the strongest evidence of the state's relative autonomy in industrial policy. Both concepts--relative autonomy and entrepreneurial politics--are founded upon the premise that state leaders merge the goal of providing public goods with the aim of securing personal political benefits in making and implementing policy. The literature has, however, largely failed to acknowledge the intersection between these two concepts. The analysis offered here suggests future studies of state autonomy and 
state industrial policy activity should take greater account of the intersection of these two concepts. 


\section{NOTES}

1. There is a certain irony in the importance Governor Goldschmidt attached to seeing the Regional Strategies program reauthorized. In part, the importance he attached to reauthorization reflected his desire to use the program as a vehicle for promoting his electoral ambitions. As happened, Regional Strategies was reauthorized and refunded, not only for the 1989-90 biennium but for the 1991-92 biennium as well. Governor Goldschmidt declined to seek reelection when his 1987-90 term expired, however, largely for personal reasons. Thus, success in seeing Regional Strategies reauthorized did not translate into political perpetuation for the Goldschmidt . Administration. Governor Goldschmidt's decision not to seek reelection was much to the writer's disappointment. For the writer had hoped that this analysis might yield some lessons on the efficacy of using arrangements like that embodied in Regional Strategies as a vehicle for political perpetuation. Governor Goldschmidt's decision not to seek reelection obviated this possibility. 


\section{REFERENCES}

\section{SOURCES CITED}

Books, Periodicals, and Other Documents

Abbott, Carl. 1983.Portland: Planning, Politics and Growth in a Twentieth-Century City. Lincoln, Nebraska: University of Nebraska Press.

Abney, Glenn and Thomas P. Lauth. 1986. The Politics of State and City Administration. Albany: State University of New York Press.

AFL-CIO. 1982. Reclaiming Oregon's Economy: The Report of the Oregon AFLCIO. Portland, Oregon: Oregon AFL-CIO.

Alford, Robert R. and Roger Friedland. 1985. Powers of Theory: Capitalism, the State, and Democracy. Cambridge: Cambridge University Press.

Ambrosius, Margery M. 1986. Effects of State Economic Development Policies on the Health of State Economies: A Time Series Regression Analysis. Paper presented at the annual meeting of the Midwest Political Science Association, April, at Chicago, Ilinois.

Amsden, Alice H. 1985. The State and Taiwan's Economic Development. In Bringing the State Back In, edited by Peter B. Evans, Dietrich Rueschemeyer and Theda Skocpol, 78-106. Cambridge: Cambridge University Press.

Anton, Thomas J. 1989. Exploring the politics of state economic development policy. Economic Development Quarterly 3(4): November:339-346.

Bergstrom, John C., H. Ken Cordell, Gregory A. Ashley and Alan E. Watson. 1990. Economic impacts of recreational spending on rural areas. Economic Development Quarterly 4:29-39.

Blakely, Edward J. 1989. Planning Local Economic Development: Theory and Practice. Newbury Park, CA: Sage.

Block, Fred. 1977. The ruling class does not rule: notes on the marxist theory of the state. Socialist Revolution 33:6-28.

Bollens, Scott A. 1989. Review of The New Economic Role of the American States: Strategies in a Competitive World Economy, edited by R. Scott Fosier. Iournal of the American Planning Association (Spring):244-245. 
Bowman, Ann O'M. and Richard Kearney. 1986. The Resurgence of the States. Englewood Cliffs: Prentice-Hall.

Bureau of Government Research and Service. 1989. Local Economic Development in Oregon. Eugene, Oregon: Bureau of Government Research and Service.

Bureau of Land Management. nd. Payments to States from OL\&C Lands. Portland, Oregon: U.S. Department of the Interior, Bureau of Land Management.

Carnoy, Martin. 1984. The State and Political Theory. Princeton, N.J.: Princeton University Press.

Center for Population Research and Census. 1988. Official Population Estimates for Oregon Counties and Cities: July 1, 1978 - July 1, 1987. Portland, Oregon: School of Urban and Public Affairs, Portland State University.

City Club. 1983. Report on Economic Development. Portland, Oregon: City Club of Portland.

Clarke, Marianne K. 1986. Revitalizing State Economies. Washington, D.C.: National Governor's Association.

Department of Commerce. various. Census of Manufacturers. Washington, D.C.: U.S. Department of Commerce, Bureau of the Census.

Department of Commerce. various. County Business Patterns. Washington, D.C.: U.S. Department of Commerce, Bureau of the Census.

Department of Labor. various.Monthly Labor Review. Washington, D.C.: U.S. Department of Labor, Bureau of Labor Statistics.

Department of Revenue. nd. Statistics on Property Taxes in Oregon. Salem, Oregon: Oregon Department of Revenue.

Dewar, Margaret E. 1987. Development analysis confronts politics." In The State and Local Industrial Policy Question, edited by Harvey A. Goldstein, 148-160. Chicago: Planner's Press.

EDD. 1987. Central Oregon Regional Strategy. Salem, Oregon: Oregon Economic Development Department.

1985. Tourism Spending in Oregon. Salem, Oregon: Oregon Economic Development Department.

-----. nd a. Administrative Guidelines to the Regional Strategies Program. Salem, Oregon: Oregon Economic Development Department.

-...-.-. nd b.Southern Oregon Regional Strategy. Salem, Oregon: Oregon Economic Development Department. 
nd c. Klamath County Regional Strategy Salem, Oregon: Oregon Economic Development Department.

Eisinger, Peter K. 1988. The Rise of the Entrepreneurial State: State and Local Economic Development Policy in the United States. Madison: University of Wisconsin Press.

Elazar, Daniel J. 1972. American Federalism: A View From the States. New York: Thomas Y. Cromwell.

Employment Division. 1986. Oregon Industrial Outlook. Salem, Oregon: Oregon Employment Division, Research and Statistics Section

----.. various. Covered Employment and Payrolls. Salem, Oregon: Oregon Employment Division, Research and Statistics Section.

-------. various. Labor Trends. Salem, Oregon: Oregon Employment Division, Research and Statistics Section.

Executive Department. various. Biennial Budget of the State of Oregon. Salem,Oregon: Executive Department.

Fainstein, Susan S., Norman I. Fainstein, Richard Child Hill, Dennis Judd, and Michael Peter Smith. 1983. Restructuring the City: The Political Economy of Urban Redevelopment. New York: Longman.

Ferguson, Ronald F. and Helen F. Ladd. 1988. Massachusetts. In The New Economic Role of the American States, edited by R. Scott Fosler, 21-87. New York: Oxford University Press.

Forest Service. nd. Payments to States from National Forest Receipts. Portland, Oregon: U.S. Department of the Interior, U.S. Forest Service.

Fosler, R. Scott (ed). 1988. The New Economic Role of American States: Strategies in a Competitive World Economy. New York: Oxford University Press.

Frohlich, Norman, Joe Oppenheimer, and Oran R. Young. 1971. Political Leadership and Collective Goods. Princeton, N.J.: Princeton University Press.

Goldstein, Harvey A. 1987. Why State and Local Industrial Policy? An Introduction to the Debate. In The State and Local Industrial Policy Question., edited by Harvey A. Goldstein, 1-10. Chicago: Planner's Press.

Gray, Virginia and David Lowry. 1986. Interest group politics and economic growth in the U. S. states. American Political Science Review 82 (March):111-131.

Gurr, Ted Robert and Desmond S. King. 1987. The State and the City. Chicago: University of Chicago Press. 
Hartman, Chester 1984. The Transformation of San Francisco. Totowa, New Jersey: Rowman and Littlefield.

Heclo, Hugh 1986. Industrial Policy and the Executive Capacities of Government. In The Politics of Industrial Policy, edited by Claude E. Barfield and William A. Schambra, 292-317. Washington, D.C.:American Enterprise Institute.

Held, David. 1987. Models of Democracy. Stanford, California: Stanford University Press.

Hibbard, Michael. 1989. Small Towns and Communities in the Other Oregon. In Oregon Policy Choices, edited by Lluana McCann, 191-202. Eugene, Oregon: Bureau of Government Research and Service, University of Oregon.

Howland, Marie. 1985. Property Taxes and the Birth and Intraregional Location of New Firms. Journal of Planning Education and Research:148-156.

Joint Legislative Committee on Trade and Economic Development. various. Minutes to the meetings of the Joint Legislative Committee on Trade and Economic Development, 1987 session. Salem, Oregon: Oregon Legislature.

----. 1986. Losing Ground: The Growing Gap Between Oregon and National Income. Staff report to the Joint Legislative Committee on Trade and Economic Development of the Oregon State Legislature.

Lampe, David (ed). 1988. The Massachusetts Miracle: High Technology and Economic Revitalization. Cambridge, Massachusetts: The MIT Press.

Leonard, H. Jeffrey. 1983. Managing Oregon's Growth: The Politics of Development Planning. Washington, D.C.: The Conservation Foundation.

Litvak, Lawrence and Belden Daniels. 1979. Innovations in Development Finance. Washington, D.C.: Council of State Planning Agencies.

Logan, John R. and Harvey L. Molotch. 1987. Urban Fortunes: The Political Economy of Place. Berkeley, California: University of California Press.

Marlin, Matthew. 1982. Evolution of a subsidy: industrial revenue bonds. Growth and Change 16(1): 30-35.

McCann, Lluana (ed). 1989. Oregon Policy Choices. Eugene, Oregon: Bureau of Governmental Research and Service, University of Oregon.

Mollenkopf, John H. 1983. The Contested City. Princeton, New Jersey: Princeton University Press.

Nordlinger, Eric A. 1981. On the Autonomy of the Democratic State. Cambridge, Massachusetts: Harvard University Press. 
Osborne, David. 1988. Laboratories of Democracy. Boston: Harvard Business School Press.

Pacific Power and Light Company. 1986. Target Industry Study. Portland, Oregon: Pacific Power and Light Company.

Pascerella, T. and R. Raymond. 1982. Buying bonds for business: an evaluation of the industrial revenue bond program. Urban Affairs Quarterly 18:73-90.

Peirce, Neil R., Jerry Hagstrom and Carol Steinbach. 1979. Economic Development: The Challenge of the 1980s. Washington, D.C.: The Council of State Planning Agencies.

Peirce, Neil R. and Jerry Hagstrom. 1984. The Book of America. New York: Norton.

Robbins, William G. 1988. Hard Times in Paradise: Coos Bay, Oregon 1850-1986. Seattle and London: University of Washington Press.

Rueschemeyer, Dietrich and Peter B. Evans. 1985. The State and Economic Transformation: Towards an Analysis of the Conditions Underlying Effective Intervention. In Bringing the State Back In, edited by Peter Evans, Dietrich Rueschemeyer, and Theda Skocpol, 44-77. Cambridge: Cambridge University Press.

Schaefer, Edward and Mary S. Hobbs. 1987. Selected Characteristics of Oregon's Population. In Oregon Policy Choices, edited by Lluana McCann, 11-34. Eugene, Oregon: Bureau of Governmental Research and Service, University of Oregon.

Schmenner, Roger W. 1983. Making Business Location Decisions. Englewood Cliffs, N.J.: Prentice-Hall.

Schultze, Charles L. 1983. Industrial policy: a dissent. The Brookings Review (Fall): 3-12.

Secretary of State. 1987-88. Oregon Blue Book. Salem, Oregon: Oregon Secretary of State

nd. Summary Report of Campaign Contributions and Expenditures: 1986

General Election. Salem, Oregon: Oregon Secretary of State.

Seidel, Karen M. 1990. Relation of Local Fiscal Condition to Economic Development. Eugene, Oregon: Bureau of Governmental and Service, University of Oregon.

Silver, Hilary and Dudley Burton. 1987. The Politics of State-Level Industrial Policy. In The State and Local Industrial Policy Question, edited by Harvey A. Goldstein 131-147. Chicago: Planner's Press. 
Skocpol, Theda. 1985. Bringing the State Back In: Strategies of Analysis in Current Research. In Bringing the State Back In, edited by Peter Evans, Dietrich Rueschemeyer, and Theda Skocpol 3-43. Cambridge: Cambridge University Press.

Slavin, Matthew I. 1993 Forthcoming. Irreconcilable Differences: Land Use Planning and Economic Development in Oregon. In Planning the Oregon Way: A Twenty Year Evaluation, edited by Carl Abbott, Sy Adler and Deborah Howe. Corvallis, Oregon: Oregon State University Press.

Steering Committee. 1987. Regional Economic Development Strategy: A Research Report. Josephine County Regional Strategy Steering Committee, prepared by Tom Bradbeer and Lyle Harrell (October 2 1987).

Steinnes, Donald. 1977. Causality and intraurban location. Journal of Urban Economics 4(1): 38-47.

Swanstrom, Todd. 1985. The Crisis of Growth Politics: Cleveland, Kucinich and the Challenge of Urban Populism. Philadelphia: Temple University Press.

Team Klamath. 1987a. Proposal for a Klamath County Regional Economic Strategy. Draft Report dated August 19, 1987.

-------. 1987b. Abbreviated Proposal for a Klamath County Regional Economic Strategy. Dated October 20, 1987.

------. 1987c. Klamath County Economic Development Strategy. Unpublished Draft dated April 23, 1987.

nd. Proposal for a Klamath County Regional Economic Strategy. Undated draft.

Technical Advisory Committee. nd. Jackson County-A Festival County. A Regional Strategy for the Oregon Comeback with Events, Products and People. Jackson County Technical Advisory Committee.

Timber Operators Council. nd. Oregon Forest Products Statistics.

V.B.B. Allen. 1987. Klamath County Regional Economic Development Strategy Document. Unpublished draft dated July 17, 1987.

Wasylenko, Michael. 1980. Evidence of fiscal differentials and intra-metropolitan firm relocation. Land Economics 56: 337-349.

Weir, Margaret and Theda Skocpol. 1985. State Structures and the Possibilities for "Keynsian" Responses to the Great Depression in Sweden, Britain, and the United States. InBringing the State Back In, edited by Peter Evans, Dietrich Rueschemeyer and Theda Skocpol, 107-168. Cambridge: Cambridge University Press. 


\section{Newspapers}

Bend Bulletin, Bend, Oregon

Klamath Falls Herald and News, Klamath Falls, Oregon

Medford Mail Tribune, Medford, Oregon

Oregon Journal, Portland Oregon

The New York Times

The Oregonian, Portland, Oregon

Interviews

Rick Allen, Mayor, Madras, Jefferson County, Oregon. January 25, 1990

Dale Allen, Regional Engineer, Oregon Department of Transportation (ODOT). January 23, 1990.

Arthur Ayre, former Research Analyst, Oregon Employment Division. December 6, 1990.

Bruce Bartow, Director, Planning Department, Josephine County, Oregon. February 8, 1990.

Bob Baugh, Oregon Economic Development Department and former SecretaryTreasurer of the Oregon Chapter of the AFL-CIO. October 23, 1989, March 5,1990 .

Dr. Larry Blake, President, Oregon Institute of Technology and Team Klamath Chairperson. January 8, 1990.

David Bolander, President, Pacific Power and Light Company and former Oregon Economic Development Commission member. November 22, 1989.

Tom Bradbeer, Assistant to the President, Rogue Valley Community College. February 8, 1990.

David Bragdon, Issues team member, Goldschmidt campaign 1986-87. October 31, 1989.

Craig Brown, Reporter, Oregon Business Magazine. October 30, 1989. 
Mike Burrill, President, Burrill Lumber and member of Jackson County Regional Economic Development Strategy Technical Advisory Committee. February 7, 1990.

Larry Campbell, Minority Leader, Oregon State House of Representatives. November 4, 1989

Michael Clark, Director, Senior Views, Grants Pass Oregon. February 7, 1990.

Ted Comini, Judge, Crook County Commission. January 24, 1990.

Joe Cortright, Executive Director, Joint Committee on Trade and Economic Development, Oregon Legislature. October 23, 1989.

Greg Cushman, Publisher, Bend Bulletin. January 23, 1990.

Mike Delman, Goldschmidt gubernatorial campaign assistant. January 29, 1991.

Sue Densmore, Marketing Consultant, Medford, Oregon and former Co-chair of Jackson County Regional Economic Development Strategy Technical Advisory Committee. February 7, 1990.

Peter Dobert, Executive Director, Central Oregon Economic Development Association (COED). January 11, 1990.

Paul Domhoffer, Director, Oregon State Marine Board. February 15, 1990.

Cynthia Ford, Director, Regional Services Institute, Southern Oregon State College and member of Jackson County Regional Economic Development Strategy Technical Advisory Committee. February 6, 1990.

Mike Freeman, Reporter, Bend Bulletin. January 10, 1990.

Gordon Fultz, Executive Director, Oregon Association of Counties. November 21, 1989.

Bruce Gallager, Director, Parks Department, Josephine County, Oregon. November $11,1990$.

Norm Gershon, Executive Director, Umpqua Training and Employment, Roseburg, Oregon and member, Oregon state House of Representatives. February 14, 1990.

Jim Gix, Regional Engineer, Oregon Department of Transportation (ODOT). February 14, 1990, October 9, 1990

Jeff Golden, County Commissioner, Jackson County, Oregon. February 5, 1990.

Peter Graff, Executive Director, Coos, Curry, Douglas Economic Development Association. February 14, 1990. 
Roger Hamilton, County Commissioner, Klamath County, Oregon. January 8, 1990.

Bob Hart, Josephine County Planning Department. February 8, 1990.

Bill Hemmingway, Former Director, Central Oregon Economic Development Association. January 27, 1990.

Mike Hollern, President, Brooks Resources, Bend Oregon and Chair, Oregon Transportation Commission. January 24, 1990.

Vera Katz, former Speaker of the Oregon House of Representatives. November 2, 1989.

Jim Keller, City Manager, Klamath Falls, Oregon. January 8, 1990.

Claudell King, Realtor, Grants Pass, Oregon and member of Josephine County Regional Economic Development Strategies Steering Committee. February 6, 1990.

Dick Knowles, Oregon Economic Development Department. February, 7, 1991.

Paul Korbulic, Director, Jackson County Parks Department. February 8, 1990.

Mike Kozak, Mayor, Bend, Oregon. January 11, 1990

Joe Kauzlarich, Manager, Grants Pass office of Pacific Power and Light Company and member of Josephine County Regional Economic Development Strategies Steering Committee. February 6, 1990.

Ted Lindow, County Commissioner, Klamath County, Oregon. January 9, 1990

Corky Leister, Former Executive Director, Josephine County Economic Development Association. February 6, 1990.

David Lohman, Assistant Director, Oregon Economic Development Department. November 21, 1989.

Debbie McCabe, Executive Director, Council for Economic Development in Oregon. October 26, 1989

Bruce McGregor, Chair of the County Board of Commissioners, Josephine County, Oregon. February 8, 1990.

Bill MacKenzie, Reporter, The Oregonian. October 5, 1990.

Mike Mahan, Regional Economist, Oregon Employment Division, Klamath Falls, Oregon. January 9, 1990.

Jeff Mapes, Reporter, The Oregonian. October 31, 1989. 
Bill Miller, Manager, Economic Development Division, Pacific Power and Light Company. November 15, 1989

Rob Miller, President, Jefferson Farms, Keizer, Oregon. November 21, 1989.

Jon Mitchell, Chief Economist and Senior Vice-President, U.S. National Bank of Oregon. November 13, 1989.

Patty O'Connor, Reporter, Klamath Falls Herald and News. January 9, 1990

Terrence O’Donnell, Historian, Oregon Historical Society. November 8, 1989.

Bill Plummer, former Manager, Pony Pass Motel, Klamath Falls, Oregon. January 12, 1990.

Lois Prante, Chair, Deschutes County Board of County Commissioners. January 24, 1990.

Richard Reiten, Former Director, Oregon Economic Development Department. February 27, 1990.

Jane Reyneke, Former Mayor, Grants Pass, Oregon. February 8, 1990.

Bob Riggs, Mayor, Prineville, Oregon. January 25, 1990.

Doug Robertson, Chair, County Board of Commissioners, Douglas County, Oregon. February 14, 1990.

Pat Sanderlin, Portland, Oregon. June 11, 1990.

Greg Satchell, Regional Strategies Coordinator, Oregon Economic Development Department. February 28, 1991.

Bill Scott, Former Campaign Manager, Goldschmidt for Governor. November 7, 1989.

Hartley Seeger, Mayor of Eagle Point, Oregon. February 6, 1990.

Gary Shaff, Senior Planner, Rogue Valley Council of Governments. February 7, 1990.

Liz Shelby, Former Executive Director, Jackson County Economic Development Council. February 5, 1990.

Mike Spencer, County Counsel, Klamath County, Oregon. January 8, 1990.

Roger Smith, Manager, Goldschmidt for Governor Campaign 1986-87 and Interim Director of Oregon Economic Development Department, 1987. December 8, 1989. 
Steve Uffleman, Mayor of Prineville. January 24, 1990.

Anita Ward, Former Candidate for Klamath County Board of County Commissioners, Klamath Falls, Oregon. January 9, 1990.

John Ward, Professor, Oregon Institute of Technology. January 9, 1990.

Karla Watson, Pacific Power and Light Company Economic Development Division. February 22, 1990.

Ralph Wehinger, Chiropractor, Eagle Point, Oregon and Former Co-chair, Jackson County Regional Economic Development Strategy Technical Advisory . Committee. February 6, 1990

Alan Webber, Associate Editor, Harvard Business Review and former aide to Portland Mayor Neil Goldschmidt. November 18, 1989.

Mike Wetter, Regional Strategies Coordinator, Oregon Economic Development Department. November 2, 1989

George Wyatt, Manager, Regional Strategies Division, Oregon Economic Development Department. February 13, 1990

\section{REFERENCE MATERIALS NOT CITED}

Almond, Gabriel A. and G. Bingham Powell Jr. 1978. Comparative Politics: System, Process, and Policy. Boston: Little, Brown and Company.

Alt, James E. 1979. The Politics of Economic Decline: Economic Management and Political Behavior in Britain Since 1964. Cambridge: Cambridge University Press.

Andrian, Charles R. 1976. State and Local Governments, 4th ed. New York: McGrawHill.

Bardach, Eugene. 1977. The Implementation Game: What Happens After a Bill Becomes a Law. Cambridge, Massachusetts: The MIT Press

Barfield, Claude E. and William A. Schambra (eds). 1986. The Politics of Industrial Policy. Washington, D.C.: American Enterprise Institute.

Bayle, T.L. 1983. Issues facing the states and governors, 1982. State Government 56(2): 65-68.

Beauregard, Robert A. (ed). 1989. Economic Restructuring and Political Response. Beverly Hills: Sage. 
Bingham, Richard D. and John P. Blair (eds). 1984. Urban Economic Development. Beverly Hills: Sage.

Bluestone, Barry and Bennett Harrison. 1982. The Deindustrialization of America: Plant Closings, Community Abandonment and the Dismantling of Basic Industries. New York: Basic Books.

Brace, Paul. 1988. Legislatures and Economic Performance. Paper presented at the annual meeting of the American Political Science Association, September 14, in Washington D.C.

-------. 1988. The Political Economy of Collective Action. Unpublished paper.

nd. Isolating the Economies of States. Unpublished paper.

Buss, Terry and F. Stevens Redburn. 1983. Shutdown at Youngstown. Albany:SUNY Press.

Charney, A.H. 1983. Interurban manufacturing location decisions and local tax differentials. Journal of Urban Economics 14: 184-205.

Cheema, G. Shabbir and Dennis A. Rondinelli (eds). 1983. Decentralization and Development. Beverly Hills: Sage.

Clarke, Susan E. 1982. Enterprise zones: seeking the neighborhood nexus. Urban Affairs Quarterly 18(1): September.

1987. More Autonomous Policy Orientations: An Analytic Framework. In The Politics of Urban Development, edited by Clarence N. Stone and Heywood T. Sanders. Lawrence, Kansas: University Press of Kansas.

and Gary L. Gaile. 1989. Moving toward entrepreneurial economic development: opportunities and barriers. Policy Studies Journal 17(3) (Spring): 574-598.

Clavel, Pierre, John Forrester and William W. Goldsmith (eds). 1980. Urban and Regional Planning in an Age of Austerity. New York: Pergamon Press.

Cox, Kevin R. (ed). 1978. Urbanization and Conflict in Market Societies. Chicago: Maaroufa Press.

Cox, Kevin R. and Andrew Mair. 1988. Locality and community in the politics of economic development. Annals of the American Association of Geographers 78: 307-325.

DeGrove, John M. 1984. Land Growth and Politics. Chicago: Planners Press.

Dery, David. 1984. Problem Definition in Policy Analysis. Lawrence, Kansas: University of Kansas Press. 
Drucker, P.F. 1986. The changed world economy. Foreign Affairs 64(4) Spring: 768791.

Edelman, Murray. 1967. The Symbolic Uses of Politics. Urbana, Ilinois: The University of Illinois Press.

Elkin, Stephen L. 1987. City and Regime in the American Republic. Chicago: University of Chicago Press.

Fiorina, Morris P. and Kenneth A. Shepsle. 1989. Formal Theories of Leadership: Agents, Agenda Setters, and Entrepreneurs. In Leadership and Politics, edited by Bryan D. Jones 17-40. Lawrence, Kansas: University Press of Kansas.

Fisher, Peter B. 1988. State venture capital funds as economic development strategy. APA Journal (Spring): 166-174.

Flieschman, Arnold and Joe R. Feagin. 1986. The politics of growth-oriented urban alliances: comparing old industrial and new sunbelt cities. Urban Affairs Quarterly 23 (December): 207-232.

Goodman, Robert. 1979. The Last Entrepreneurs: America's Regional Wars for Jobs and Dollars. New York: Simon and Schuster.

Grady, Dennis O. 1989. Economic development and administrative power theory: a comparative analysis of state development agencies. Policy Studies Review 8(2) (Winter): 322-339.

Grant, Jane A. 1990. Making policy choices: local government and economic development. Urban Affairs Quarterly. 26(2) (December): 148-169.

------. 1990. The corporatist foundations of state industrial policy. Social Science Quarterly 71(1) March: 1-24.

Hall, Peter. 1980. Great Planning Disasters. London: Weidenfeld and Nicholson.

Hart, Stuart L., Daniel R. Denison, and Douglas A: Henderson. 1989. A contingency approach to firm location: the influence of industrial sector and level of technology. Policy Studies Journal 17(3) (Spring): 599-623.

Hawkins, Benjamin M. 1984. The impact of enterprise zones on urban areas. Growth and Change 15(1) (January).

Jacob, Herbert and Kenneth N. Vines. 1965.Politics in the American States. New York: Praeger.

Jewell, Malcolm. 1982. The neglected world of state politics. Journal of Politics 44(3) August: 638-658.

Jones, Bryan D. 1989. Leadership and Politics. Lawrence, Kansas: University Press of Kansas. 
Kale, Steven. 1984. U.S. industrial development incentives and manufacturing growth during the 1970s. Growth and Change 15: 26-34.

Kelman, Steven. 1987. Making Public Policy. New York: Basic Books.

Kieschnick, Michael. 1981. Taxes and Growth: Business Incentives and Economic Development. Washington, D.C.: Council of State Planning Agencies.

Kuttner, Robert. 1984. The Economic Illusion. Boston: Houghton Mifflin Company.

Lauman, Edward and David Knoke. 1987. The Organizational State: Social Choice in National Policy Domains. Madison, Wisconsin: The University of Wisconsin Press.

Markusen, Ann R. 1980. Regionalism and the Capitalist State. In Urban and regional Planning in the Age of Austerity, edited by Pierre Clavel, John Forrester, and William W. Goldsmith, 31-52. New York: Pergamon Press

1987. Regions: The Economics and Politics of Territory. Totowa, N.J.:Rowman and Littlefield.

-------. 1989. Industrial Restructuring and Regional Politics. In Economic Restructuring and Political Response, edited by Robert A. Beauregard, 115148. Beverly Hills: Sage.

Mazmanian, Daniel and Paul A. Sabatier. 1983. Implementation and Public Policy. Glenview, Illinois: Scott, Foresman and Company.

McGuire, Theresa. 1985. Are property taxes important in the intra-metropolitan location decisions of firms. Journal of Urban Economics 8.

McHone, W. Warren. 1984. State industrial development incentives and employment growth in multistate SMSAs. Growth and Change 15(4): 8-15.

Migdal, Joel S. 1988. Strong States and Weak Societies: State-Society Relations and State Capabilities in the Third World. Princeton, New Jersey: Princeton University Press.

Molotch, Harvey L. The city as a growth machine: towards a political economy of place. American Journal of Sociology 82(2): 309-322.

Mueller, Dennis C. 1983. The Political Economy of Growth. New Haven: Yale University Press.

Nagel, Stuart S. 1983. Encyclopedia of Policy Studies. New York: Marcel Dekker, Inc.

------. 1984. Contemporary Public Policy Analysis. University, Alabama: The University of Alabama Press. 
Nakamura, Robert T. and Frank Smallwood. The Politics of Policy Implementation. New York: St. Martins Press.

Neenan, William B. and Marcus E. Etheridge. 1984. Competition and Cooperation Among Localities. In Urban Economic Development, edited by Richard Bingham and John P. Blair 175-190. Beverly Hills: Sage.

Newman, R.J. and D.H. Sullivan. 1988. Econometric analysis of business tax impacts on industrial location: what do we know and how do we know it? Journal of Urban Economics 23(2):215-234.

Nice, David. 1987. Federalism: The Politics of Intergovernmental Relations. New York: St. Martins Press.

Okimoto, Daniel I. 1986. Regime Characteristics of Japanese Industrial Policy." In Japan's High Technology Industries, edited by Hugh Patrick, 35-96. Seattle: University of Washington Press.

Olson, Mancur. 1972. The Rise and Fall of Nations. New Haven: Yale University Press.

Patton, Spiro. 1985. Tourism and local economic development: factory outlets and the reading SMSA. Growth and Change 16 (July): 64-72.

Peterson, Paul E. 1981. City Limits Chicago: The University of Chicago Press.

Pressman, Jeffrey and Aaron Wildavsky. 1973. Implementation. Berkeley, California: The University of California press.

Reinshuttle, Robert. n.d. Economic Development: A Survey of State Activities. Lexington, Kentucky: Council of State Governments.

Sharkansky, Ira (ed). 1970. Policy Analysis in Political Science. Chicago: Markham Publishing Company.

Skocpol, Theda and Kenneth Finegold. 1982. State Capacity and Economic Intervention in the Early New Deal. Political Science Quarterly 97: 255-278.

Stoker, Robert P. 1989. A Regime Framework for Implementation Analysis: Cooperation and Reconciliation of Federalist Imperatives. Policy Studies Review 9(1): 29-49.

Thompson, L. 1983. The politics of economic development: a qualitative case study.Urban Resources 1: 33-40.

Wassell, G. and D. Helman. 1985. Financial incentives to industry and urban economic development. Policy Studies Review 4:626-639. 
Whitelaw, W. Ed and Ernie Niemi. 1989. Oregon's Strategic Economic Choices. In Oregon Policy Choices, edited by Lluana McCann. Eugene, Oregon: Bureau of Governmental Research and Service, University of Oregon. 
APPENDIX

HB 3011: THE REGIONAL ECONOMIC DEVELOPMENT ACT 


\section{Enrolled}

House Bill 3011

Sponsored by COMMITTEE ON TRADE AND ECONOMIC DEVELOPMENT

CHAPTER

AN ATT

Relating to the Oregon Combbeck: and deckaring an emergeney.

Be lt Enneted by the People of the Sinte of Oregons

SECIION I This Aet stuall be known as the Retional Economis Development Aet.

SECIION a As and in this Aet, uniess the context requires otherwise:

(II "Deparement" meane the Eeonowic Deviopmen Deparoment

(2) "Regios" means a county or groups of counties thas join egether to develop and impiement en economic strats.

(4) "Regional stratey" is ian economic development plan to build or eniarge a principal eco nomic activity celected by the region and is eitioem.

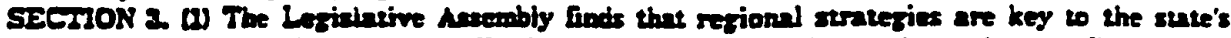

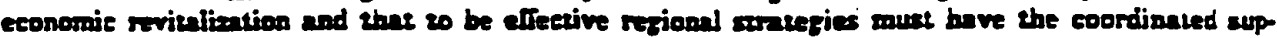
por of avaibible nesurcal.

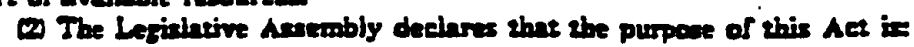

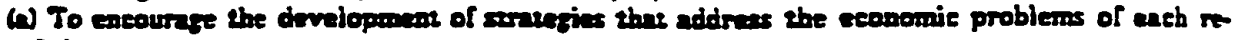
gion of the antes

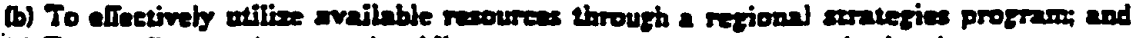

(t) To coortinate private and publie rewources 20 auppors esonomie development

SECIION \& (I) Niot inter, than 00 days after the effective date of this Aeta by rule, the dit-

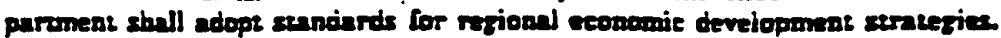

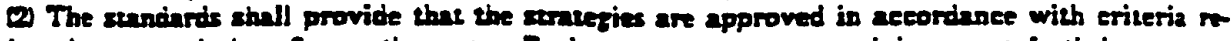

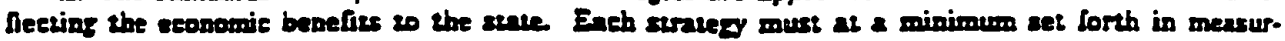
able terms the erent 20 which the surateg will:

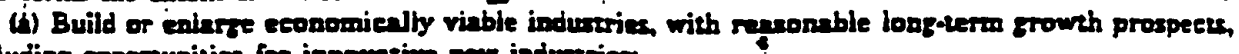
ineiudiag opportunities for innovative sow induntrier

(b) Result is a set benefit so the sente in the loos lerm asd oot require costinuing stale subsidies

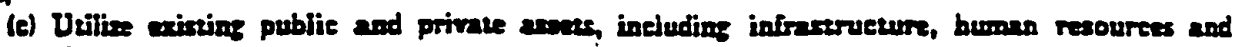
piant and equiproent:

(d) boprove the conditiogs of the economieally diadvantaged and inerene the number of lamily ware jober

(t) Harnes Orezon's comparative advantage with exophasis on the grown and deveiopment of

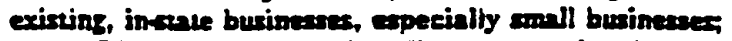

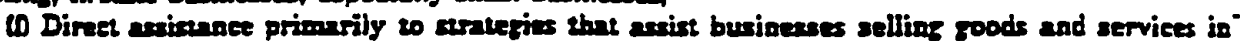
markeus for which netional or interantional exupetition exirrs;

(c) Result in the economic revitulization of andl civies and undierdieveioped urban and rural arens; and 
(h) Acsure that public investments to implement a strategy ore matched. to the maximum extent : possible, by the sontribution of privale financial and other resources.

(3) The depurzment shull expedite and facilitate the definition of regions, based on historical. cultural and eeonomic links among counties by recommending potential groupungs of counties to form regiosus.

SECTION S. Rezional economic development stralegies shall serve as a busis for state financial ausisunce 10 projects 20 aid a regional economy. Each county or group of counties that form a region shall submil a regional stralezy which at a minimum shall iaciude the following elements:

(2) An identification of the principal industry or economic activity that the region is secking to stimulate with its regional strategy:

(2) An analysis of the unique or signifienat resources that provide the foundation for the strat. ext:

(a) An evaluation of altemative resources and altermative strategies for the rezion;

(4) An anaiysis of barriers 20 developmeat of the salected eeonomic activity in the region and an identifiention of the means 10 overeome those barriers;

(B) A list of actions 20 implement the regional stratezy, including actions by:

(a) Loenl sovernments;

(b) The private sector,

(c) SLare government; and

(d) Fedieral Government;

(6) A prioritized list of activities to be underaken or funded by the state from lotwery prosecds and ocher sourters

(7) A plan for involvemeat of diendvantaged and minority groups in the regional stratefies and

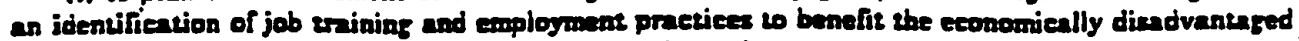

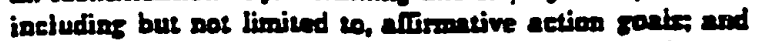

(1) A deseripsion of the number and types of jobs ereatod, isverements made and other menur. able.indientions of economic protras as ett forth in section 4 of this Att

SECIION C (1) The goveraing body of each counxy of this state shall be ruponsibie for the submixion of a rojional stratery a providad in seetion 5 of this Aet The goveraing body of a county my, by ordiannee, dalegnte its respomibility under this section to another body. Wherever

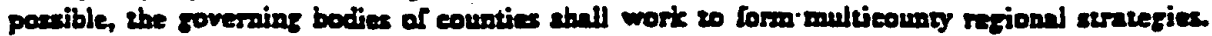

(2) Individually or in coneers with the govming bodies of othir coumies, the governing body of ench eounty shall solieit publit coumenen and involverwent in the developenent of idens and sug.

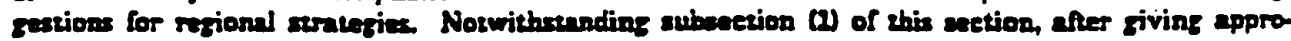
priase notice, eat eounty soverning body shall at least once hold a public hearing to receive surerestions.

(3) Individually or in coneert with the goveraiag bodies of other councios and aner giving appropriate publie nosiee nos leas than iwo weeles prios, the governing body of each county or the body dexignated 20 propare the regional stranes shall bold a public beariag in each eounty in the region prior to a vole to recomment to the Covernor the recional stratogy daseribed in section 5 of this Aet.

BECIION 7. (1) Aler comideriog the recommentation submitud under metion 6 of this Act

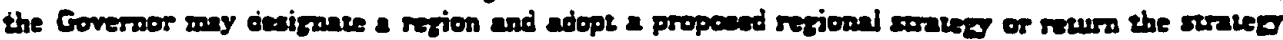
to the allected countie for modifiention.

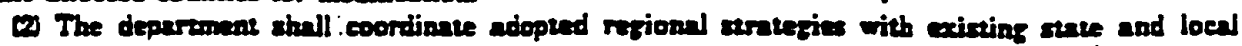

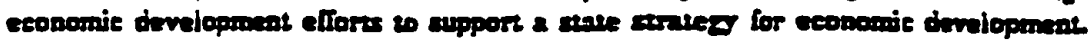

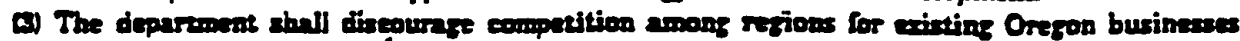
and economic aetivity.

EECIION \& (I) in earryiag out the proviniom of this Aet the deparameat stall work to assure

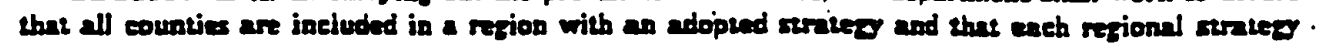
is considered for implementerion not Later than July \& 1989 
(2) A region shall not be entilled to fundiag under this Act in exceas of the amount specified in the regional stratesy adopted by the Governor prior to the time that each other region of the state has received initial fundine for the priority activities within its approved strateey.

SECTION 9. The department shall consult with the Lepislative Commillese on Trade and Eco. nomic Develupment on the desiznation of regions, the adoption of reciomal stratezies, the expendi. ture of funds on behalf of such stratecies and the accomplishments of such strategies.

SECTION 10. This Aet being meceatary for the immediate preservation of the public pence, havalth and afety, an emergeney is declared to exish, and this Act akea effeet on its paseage.

Pand by Howe April 2 , 200

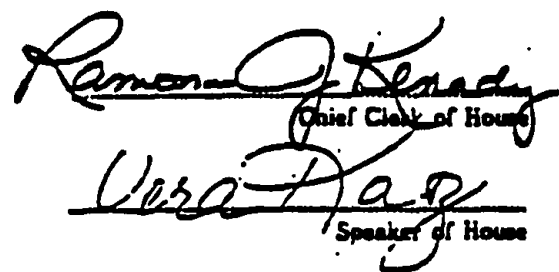

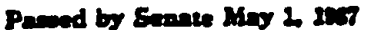

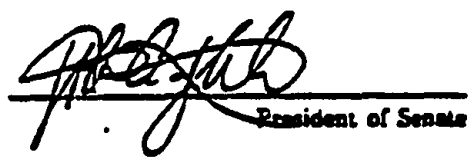

Roeeinod by Coverwen

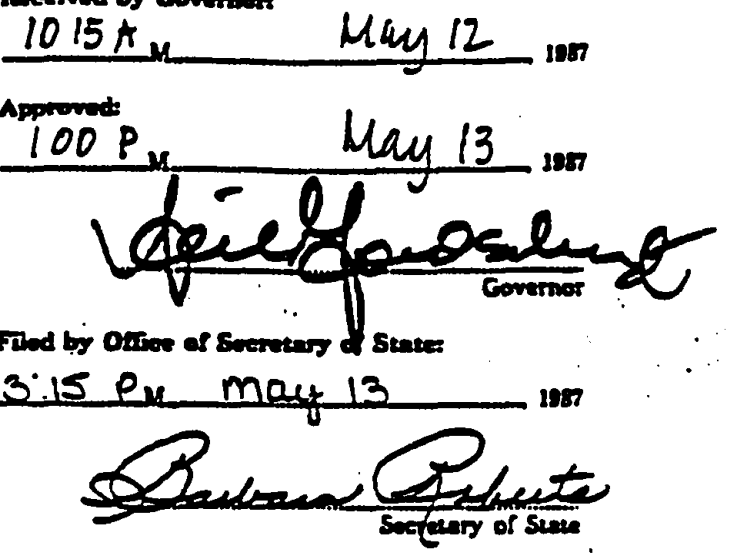

